\title{
The Emerging Modern Greek Nation and British Romantic Literature
}

\author{
by
}

Alexander Grammatikos

A thesis submitted to the Faculty of Graduate and Postdoctoral Affairs in partial fulfillment of the requirements for the degree of

Doctor of Philosophy

in

English Language and Literature

Carleton University

Ottawa, Ontario

(C) 2017, Alexander Grammatikos 


\begin{abstract}
This dissertation contributes to the field of British Romantic Hellenism (and Romanticism more broadly) by emphasizing the diversity and complexity of Romanticera writers' attitudes towards, and portrayals of, Modern Greece, especially the ways that early nineteenth-century British literature about contemporary Greece helped to strengthen British-Greek intercultural relations and, ultimately, to situate Greece within a European sphere of influence. My study primarily focuses on fictional works because, as I demonstrate, Romantic literature, more than any other network of discourses of the early nineteenth century, intervened in debates about Modern Greece not merely by documenting facts but by creating realities, portraying imagined Greek-British encounters that encouraged readers to envisage new social, political, geographical, and cultural vistas and alliances for both Greece and Britain. As I argue, British Romantic writers' representations of cross-cultural relations between Greeks and Britons gesture toward their growing sense of, and concern with, Britain's international conduct and reputation, especially after 1815 when Britain was transforming into a dominant imperial power. The writers I examine use Modern Greece and Hellenism to interrogate and understand their country's role not only within Greece, but also within a transnational, global world, the geopolitical dynamics of which were in flux. In discussing GreekBritish Romantic-era intercultural relations, my study focuses on the wide range of private and public political positions available to British Romantic writers and emphasizes that the Greek War of Independence and Greece's subsequent liberation were not isolated national events, but instead the outcome of the political, cultural, and literary debates and discourses taking place for at least half a century in Europe and Greece. By
\end{abstract}


rooting my literary analysis in the historical, cultural, and geopolitical, I provide an account of British Romantic Hellenism that emphasizes the ways in which British writers engaged with a variety of discourses in reproducing versions of Greece that concretized the country. Greece is no longer merely the (imagined) topos of a glorified ancient people or of a degraded modern populace, but repositioned by British Romantic writers as a country integral to the modern, global world of the early nineteenth century. 


\section{Acknowledgements}

This dissertation would not have been possible without the intellectual, emotional, and financial support I have received from various family members, friends, professors, colleagues, and institutions during my academic studies. Paul Keen — thank you for encouraging me to pursue my literary interests, for helping me to both shape and refine my ideas, and for celebrating my successes. You have been a great supervisor and friend. Julie Murray-I have appreciated your intellectual generosity and personal warmth over the last six years. Thank you for being an amazing mentor and friend. Andrew Wallaceyour astute and very kind feedback on my writing has been tremendously beneficial. Thank you, too, to John Osborne and Jonathan Sachs for agreeing to join my dissertation committee and for offering feedback on my work.

This dissertation was supported financially through a Social Sciences and Humanities Research Council (SSHRC) Doctoral Fellowship, an Ontario Graduate Scholarship, a Graduate Research and Innovative Thinking Award, an Alfred and Isabel Bader Student Travel Award, a George Alexopoulos Memorial Scholarship, and a Gordon J. Wood Graduate Scholarship in English. The Carleton University, Simon Fraser University, and University of Athens libraries provided me with most of the materials necessary to write this dissertation; thank you to the many staff members at all of these institutions that have helped me over the years.

My early passion for Romantic Hellenism began at Simon Fraser University with my BA Honours supervisor Michelle Levy and was further pursued during my MA studies at The University of York with Stephen Minta and Jane Moody. I am grateful to all three of these professors for their knowledge, mentorship, and faith in my abilities. 
My fellow Carleton PhD students—some of whom have themselves now finished their degrees - have been the best of academic colleagues and friends. I especially want to thank Chris Doody, Emma Peacocke, Kim Sigouin, Aliesha Hosein, Andrew Connolly, Adam Benn, and Shaun Stevenson. Thank you to Maria Schoina, Kandice Sharren, Eirini Kotsovili, Hugh Reid, and Roderick Beaton for providing me with insightful feedback and suggestions on my writing and to Aleks Jovanovic for reading every chapter of this dissertation and enlightening me with your extensive knowledge of the Byzantine Empire. From "When is that event happening again?" to "Have I missed the deadline?", Lana Keon, the English Department's Graduate Administrator, has always dealt with my questions and concerns with great patience and skill. Thank you, Lana.

My family and friends have always supported me, even if they weren't always certain what it was I was studying. Thank you to my Mom and Dad who worked hard to ensure that their children would have the opportunity to go to university. Thank you to Terry and Lynn for always asking how the writing was going. Unfortunately I cannot name all of my friends here, but thanks Pete, Buffy, Mike, Samantha, Pamela, Nastazia, Aleks, Christo, and Haley for keeping me grounded and for making me laugh.

And finally, thank you Shawna. We have gone on this long academic journey together and I couldn't have asked for a better partner. Throughout our relationship, you have inspired me to become a better learner and person. I could not have done any of this without you. 


\section{Table of Contents}

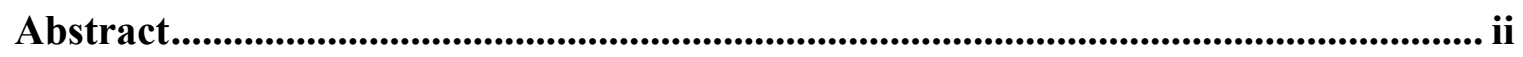

Acknowledgements .................................................................................................................... iv

Table of Contents ........................................................................................................... vi

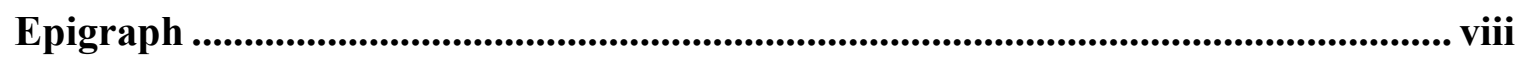

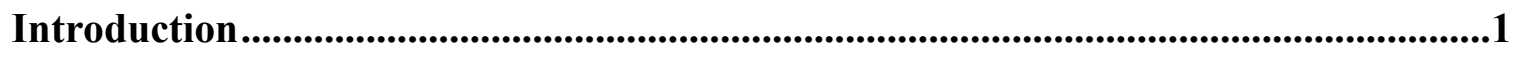

Discovering Modern Greece ..................................................................................

East Becomes West: Making a European Greece .......................................................8

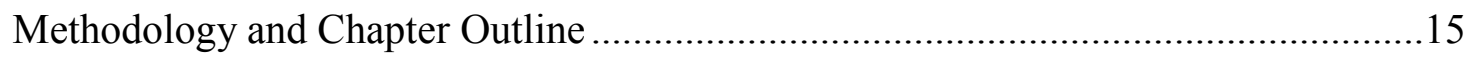

\section{Chapter One}

Caught Between East and West: Negotiating Modern Greek Identity in Ida of Athens and Anastasius ..............................................................................................22

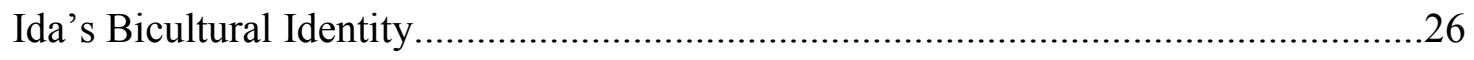

The Advantages and Drawbacks of Transcultural Relationships ..............................34

Greece-West Estrangement in Anastasius ................................................................42

Anastasius Negotiates His Greek Identity ...........................................................50

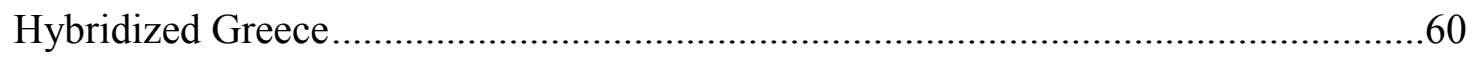

\section{Chapter Two}

"Let Us Look At Them As They Are": Lord Byron and Modern Greek Language, Literature, and Print Culture ...................................................................................63

The Edinburgh Review and Modern Greek Print, Literature, and Language ................70

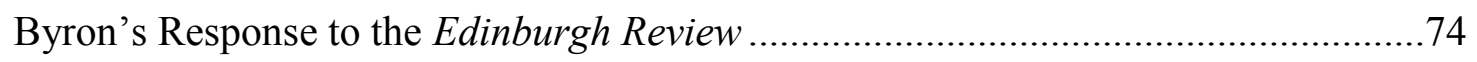

Language Debates and Greek National Identity in the Early Nineteenth Century .......85 
"Note III" and the "Appendix," Childe Harold II, and Greek-British Cultural Relations

\section{Chapter Three}

There's No Place Like Homeland: Victimized Greek Women, The Greek War of Independence, and the Limits of European Philhellenism...............................................99

Captive Greek Women and the Limits of British Philhellenism.................................102

"Riddles of Death Thebes Never Knew": The Chorus of Greek Captive Women in Hellas

“Zoë Mou, Sas Agapo": Greek-British Relations and Western Dominance in Reine Canziani.....

"Man May Not Fetter, Nor Ocean Tame / The Might and Wrath of the Rushing Flame!": Greek Female Self-Determinism in "The Bride of the Greek Isle"

Symbols of the Nation

\section{Chapter Four}

All Roads Lead to Constantinople: Re-Historicizing Greek-British Relations in The
Travellers and The Last Man ........................................................................................161

"Here Lyeth the Body of Theodore Palaeologus": Greece, Britain, and the Byzantine

Past.

Alexis's Death, Sidney and Ianthe's Marriage, and British Proprietorship over Greece's Past

"Raymond Was Loved By Evadne": A Greek Tragedy......

"On the Height of St. Sophia": Constantinople and the Perils of East-West Conflict

"I Will Leave a Monument of the Existence of Verney": The Plague in Britain and the Advent of a New History 197

Greece, Britain, and the Problematic of European Modernity . 202

Conclusion 206

Works Cited .216 
The modern Greeks revel almost to intoxication in the grandeur of their lineage and in the ancient supremacy of their politics, art, philosophy, and literature. But their contemplation of the past is simply an element in the revival of a strong race feeling. They live intensely in the present, and yet more intensely in the future. They are the most buoyantly hopeful and ambitious race in Europe. Their condition has been very low, and remains difficult and perplexing; but they are making progress that promises brilliant fruitage, and their enthusiastic confidence in their own destiny sometimes exposes them to ridicule. They sit in the cafés and marketplaces reading their crisp little daily newspapers and discussing every move on the great checker-board of European politics as having some deep and intentional bearing upon the future of Greece. As in the other small states of Europe, political development in Greece has preceded industrial development; and politics is a principal business and absorbs the best talent, while political journalism also flourishes luxuriantly.

-Albert Shaw, “The Greeks of To-day” (The Chautauquan, June 1890) 


\section{Introduction}

\section{Discovering Modern Greece}

British Romantic Hellenism boasts a long and rich critical tradition that includes a range of scholarship examining late eighteenth- and early nineteenth-century Britain's multiple preoccupations with Greece, including the country's (often idealized) ancient past and the Modern Greeks' war of independence against the Ottoman Empire. ${ }^{1}$ This dissertation contributes to the field of British Romantic Hellenism (and Romanticism more broadly) by emphasizing the diversity and complexity of Romantic-era writers' attitudes towards, and portrayals of, Modern Greece, especially the ways that early nineteenth-century British literature about contemporary Greece helped to strengthen British-Greek intercultural relations and, ultimately, to situate Greece within a European sphere of influence. My study primarily focuses on fictional works because, as I demonstrate, Romantic literature, more than any other network of discourses of the early nineteenth century, intervened in debates about Modern Greece not merely by documenting facts but by creating realities, portraying imagined Greek-British encounters that encouraged readers to envisage new social, political, geographical, and cultural vistas and alliances for both Greece and Britain. The literature I discuss in this dissertation is concerned not only with understanding and depicting Modern Greece for a British audience but, significantly, with reconfiguring and reconceptualizing Britain and Greece's past, present, and future relations.

The Romantic era represented a turning point in both Modern Greek and British histories. Greece in the late eighteenth century, although still an Ottoman territory, was becoming politically, socially, economically, and culturally more prosperous. Greek merchants controlled

\footnotetext{
${ }^{1}$ The term "Romantic Hellenism" was coined in 1931 by Harry Levin in his The Broken Column: A Study in Romantic Hellenism, Bowdoin Undergraduate Prize Essay. Cambridge, MA: Harvard University Press, 1931. Levin's study focuses on the ways in which male Romantic poets engaged with the Ancient Greek past.
} 
"a considerable portion of the [Ottoman] [E]mpire's internal and external trade" (Mouzelis 93), Greek writers published numerous fictional and non-fictional works, Greek educators established schools in main economic and cultural centres, Greek clerks in the Ottoman imperial administration began to obtain prestigious governmental positions, and Greek intellectuals attended universities throughout Europe. ${ }^{2}$ Greece's growing stability and affluence, in turn, encouraged Greeks to seek liberation from their Ottoman rulers and, although the Greeks' first two attempts at independence in 1770 and 1788 ended in failure, these unsuccessful uprisings set the precedent for the 1821 War of Independence that witnessed Greece in 1832 become, with substantial European support, a sovereign nation state. ${ }^{3}$

While late eighteenth and early nineteenth-century Greeks were experiencing political, cultural, literary, and economic developments which witnessed them become more closely acquainted with the Western world and which encouraged them to seek national liberation, Britain too was undergoing dramatic political and social transformations that influenced its international relations with Greece. For a decade and a half of the Romantic era, Britain was embroiled in war with Napoleonic France, a rivalry that concluded with Britain becoming a

\footnotetext{
${ }^{2}$ Reşat Kasaba gives an account of eighteenth- and nineteenth-century Greek mercantile activity in The Ottoman Empire and the World Economy: The Nineteenth Century (Albany: State University of New York Press, 1988). As Kasaba writes: "Interstate politics that contributed to the expansion of Ottoman exports to Europe in the late eighteenth century were also an important factor in the rise of the non-Muslims, especially the Greek merchants in the western provinces of the Ottoman Empire. The opportunities for speculation and profiteering no doubt enhanced the position of the overland careers. But most significantly, these successive upheavals created a space for the Greek merchant marine to expand and, for a limited time, even monopolize shipping in the Aegean, Adriatic, Black Sea,

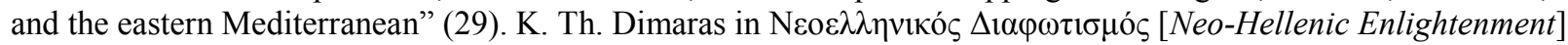
(Athens: Filippos Iliou, 1989) and Paschalis M. Kitromilides in Enlightenment and Revolution: The Making of Modern Greece (Cambridge, Massachusetts: Harvard University Press, 2013) discuss advances in education and literary production. Christine Philliou in Biography of an Empire: Governing Ottomans in an Age of Revolution (Berkeley: University of California Press, 2011) gives a fascinating account of Phanariot Greeks working as diplomats in the Ottoman Empire's administration. See too G.P. Henderson, The Revival of Greek Thought 16201830 (Albany: State University of New York Press, 1970) for chapters on various Greek Enlightenment thinkers; and Linos Politis, A History of Modern Greek Literature (Oxford: Clarendon Press, 1973) for an overview of Greek literary works composed and published during the Romantic period.

${ }^{3}$ William St. Clair's That Greece Might Still Be Free remains the go-to study on British and European intervention in the Greek War of Independence. See William St. Clair, That Greece Might Still Be Free: The Philhellenes in the War of Independence. Oxford: Oxford University Press, 1972. See too C.M. Woodhouse, The Philhellenes. London: Hodder and Stoughton, 1969.
} 
dominant power in Europe after 1815, the year in which the British army, led by the Duke of Wellington, defeated the French at the Battle of Waterloo. ${ }^{4}$ In 1815, Britain, Austria, Prussia, and Russia established the Concert of Europe (France later joined) at the Congress of Vienna, a federation designed to prevent further waring amongst European countries and which allowed Britain to continue to develop as an imperial power and increase its presence in the political affairs of other countries, including Greece. ${ }^{5}$ Perhaps unsurprisingly, the 1815 Congress of Vienna, where the Concert of Europe was established, also marked the beginning of Britain's colonial rule over the majority Greek-inhabited Ionian Islands, as Europe's great powers agreed to make the islands a British "protectorate." The Ionian Islands' cession to British rule provides just one example of the ways that British and Greek geopolitical and sociocultural spheres and destinies became intertwined during the Romantic period, particularly following the conclusion of the Napoleonic Wars.

As I argue in my dissertation, British Romantic writers' representations of cross-cultural relations between Greeks and Britons gesture toward their growing sense of, and concern with, Britain's international conduct and reputation, especially after 1815 when Britain was transforming into a dominant imperial power. ${ }^{7}$ The writers I examine use Modern Greece and

\footnotetext{
${ }^{4}$ In Britons: Forging the Nation 1707-1837 (New Haven: Yale University Press, 1992), Linda Colley gives an extensive account of the Napoleonic Wars and the ways in which Britons used war with France to "forge" their national identity and empire. See too Roger Knight, Britain Against Napoleon: The Organization of Victory 17931815. London: Penguin, 2014; Rory Muir, Britain and the Defeat of Napoleon, 1807-1815. New Haven: Yale University Press, 1996; and Simon Bainbridge, Napoleon and English Romanticism. Cambridge: Cambridge University Press, 1995.

${ }^{5}$ For more on the Congress of Vienna, see Tim Chapman, The Congress of Vienna: Origins, Processes and Results. London: Routledge, 1998.

${ }^{6}$ Britain ruled the Ionian Islands between 1815 and 1864, at which time Britain ceded the islands to Greece. Although the Ionian Islands were nominally a "protectorate," Lord High Commissioners from Thomas Mainland onwards treated the islands like an imperial colony. For more on Britain's rule over the Ionian Islands, see Michael Pratt, Britain's Greek Empire: Reflections on the History of the Ionian Island from the Fall of Byzantium. London: Rex Collings, 1978; and Maria Paschalidi, Constructing Ionian Identities: The Ionian Islands in British Official Discourses; 1815-1864. PhD Diss. University College London, 2010.

${ }^{7}$ In Romantic Globalism: British Literature and Modern World Order 1750-1830. (Ohio: Ohio State University Press, 2014), Evan Gottlieb argues that the Romantic period represented the advent of today's global world wherein
} 
Hellenism to interrogate and understand their country's role not only within Greece, but also within a transnational, global world, the geopolitical dynamics of which were in flux. Significantly, Romantic writers recognized that the European political domain —and, as is relevant to my study, the sociopolitical spheres of Britain and Greece - remained unstable and thus open to modifications. Europe's unsettledness (politically, but also as a cultural construct) allowed Romantic authors to use their works to endorse a range of personal and political positions concerning the development of Greek-British relations. If the Romantic period represents an era in which a conservative, anti-revolutionary Britain grows into its role as the world's preeminent imperial power, it is also a time during which liberalism and cosmopolitanism flourish and I argue that the tensions between conservative and liberal politics were productive in shaping ideas about Greece. True, the Tory British Government may not have initially supported Greek independence, but their official position only encouraged British liberals - who had before the Greek revolution supported causes like the Spanish and Italian revolutions and rallied for democratic rights, the culmination of which in England is perhaps the 1832 Representation of the People Act— to act and write on behalf of the Greeks. ${ }^{8}$ In discussing Greek-British Romantic-era intercultural relations, my study focuses on the wide range of private and public political positions available to British Romantic writers and emphasizes that the Greek War of Independence and Greece's subsequent liberation were not isolated national events, but instead the outcome of the political, cultural, and literary debates and discourses taking place for at least half a century in Europe and Greece.

\footnotetext{
Britain began to both negotiate and expand its role on the world stage and in other country's affairs. According to Gottlieb, " 1750 is a productive starting place for a study of Romantic globalism because it also corresponds to the start of what Roland Robertson identifies as the second, 'incipient' phase of long-durational globalization" (4).

${ }^{8}$ For more on the 1832 Representation of the People Act or, as it is often referred to, the 1832 Reform Act, see Eric J. Evans, The Great Reform Act of 1832. London: Routledge, 1832.
} 
My study, which examines the ways in which late eighteenth- and early nineteenthcentury British writers conceptualized Modern Greece and its people and how these literary engagements with Greece produced, ratified, and complicated Britain's relationship with the emerging Greek nation, represents an important addition to the field of Romantic Hellenism. While scholars of Romantic Hellenism, including Timothy Webb, Jennifer Wallace, and David Ferris have illustrated the complexity of British writers' engagement with Ancient Greece and how the aesthetic and sociopolitical are interconnected in writings about the Greek past, this dissertation emphasizes that a similar level of complexity and diversity existed in British Romantic works about Modern Greece. ${ }^{9}$ Essentially, my dissertation seeks not to valorize certain discourses or to read British works about Modern Greece as thematically homogenous, but instead to accentuate the heterogeneous nature of British responses to the idea of Modern Greece. In The Archaeology of Knowledge, Michel Foucault endorses reading works with "a field of strategic possibilities" in mind, "[r]ather than seeking the permanence of themes, images, and opinions through time, rather than retracing the dialectic of their conflicts in order to

\footnotetext{
${ }^{9}$ Jennifer Wallace begins her Shelley and Greece: Rethinking Romantic Hellenism (New York: St. Martin's, 1997) by stating: "For too long, writing about $[\mathrm{H}] \mathrm{ellenism}$ has been associated with the study of a perfect civilisation" (1) before going on to argue that "[ $[\mathrm{t}] \mathrm{he}$ varied response to Greece by different writers reveals the heterogeneity of classical influence. The interest in ancient Greece becomes less a case of simple conformity when, with different ideas of the ancient world emerging, it becomes unclear exactly to what model of Greece all writers can and do conform" (2-3). When Wallace discusses Greece, she usually refers to Ancient Greece- the main focus of her significant "rethinking" of Romantic Hellenism. Timothy Webb's earlier monograph, English Romantic Hellenism (Manchester: Manchester University Press, 1982), features selections from 34 works by various Romantic-era authors who write about Ancient Greece. Webb's Introduction sketches out the history of and precedents to British Romantic Hellenism. David S. Ferris's more recent Silent Urns: Romanticism, Hellenism, Modernity (Stanford: Stanford University Press, 2000) examines how Romantic writers use the Hellenic past to define their modernity and to support the ideology of freedom. Ferris depicts Romantic Hellenism as not merely a revival of an idealized Ancient Greek past that artists seek to emulate, but as a cultural formation that allowed writers of the late eighteenth and early nineteenth centuries to examine and confront the historical and cultural issues of their own period. Using Johann Winckelmann's History of Ancient Art (1764) as a focal point (Silent Urns is a study of European, rather than exclusively British, Romantic Hellenism), Ferris argues that the German art historian's insistence on the connectedness between Ancient Greek aesthetics and modern politics influenced the political, cultural, and historical meditations of later writers, including Percy Bysshe Shelley and John Keats. Ferris's study emphasizes that Romantic Hellenism informed the cultural, social, and historical politics of the late eighteenth and early nineteenth centuries and suggests that Romantic Hellenists considered the aesthetic as "the rhetoric of the political, rather than an ideology to be opposed to history" (80).
} 
individualize groups of statements" (37). In this dissertation, I heed Foucault's warning against "the individualization of a discourse" (36) and emphasize the range of opinions, critiques, and value judgments British Romantic writers make about Greece (and Britain) in their publications about Modern Greece. Rather than seeking consistency of theme or opinion within a single work or consensus amongst many works, it may be more productive to highlight the multiplicity of discourses about Modern Greeks present in and amongst British Romantic publications. British Romantic literary works about Modern Greeks were, I argue, necessarily discordant and cacophonous as they attempted to rectify political, social, cultural, and national issues that were in the process of being discovered, created, debated, and resolved.

Throughout my dissertation, I underscore how British Romantic works about Modern Greece reflect Britain's sociopolitical condition as much as they do Greece's. To emphasize British writers' multiple personal and political commitments and to contextualize their portrayals of cultural hybridity, I look to Mary Louise Pratt's concept of "contact zones," defined by her as "social spaces where cultures meet, clash, and grapple with each other, often in contexts of highly asymmetrical relations of power, such as colonialism, slavery, or their aftermaths as they are lived out in many parts of the world today" (7). For Pratt, "contact zones" are spaces wherein different cultures interact, resulting oftentimes in the subjugation of one culture to another, but also allowing for a breakdown of cultural boundaries and the recognition of similar institutions and beliefs and a common humanity among people. I am interested in how British Romantic literature about Modern Greece created "contact zones" which allowed readers to contemplate the political, social, and ideological challenges of the Romantic period and to learn about the everyday lived realities of Modern Greeks. 
In fact, I argue that by producing literature which imagined various versions of Greece and Britain and of Greek-British relations, British Romantic writers took part in the process of transforming both Greek and British identities. In The Location of Culture, Homi Bhabha proposes that "[i]t is in the emergence of the interstices - the overlap and displacement of domains of difference - that the intersubjective and collective experiences of nationness, community interest, or cultural value are negotiated" (2). Bhabha's argument about negotiating identity is pertinent to my focus on how British writers use encounters (or, to use Pratt's term, “contact zones") between Greeks and Britons to meditate upon questions of cultural, political, and (emerging) national similarities and differences. The writers I discuss in my dissertation represent relationships between Britons and Greeks as transformative for both (or all) parties involved, as in Sydney Owenson's Ida of Athens (Chapter One) and Tertius Kendrick's The Travellers (Chapter Four). ${ }^{10}$ In these works, elements of both Greek and British culture (imagined or otherwise) encounter each other in ways that destabilize essentialist notions of identity—personal, national, or otherwise. Cultural contact between Britons and Greeks, British Romantic writers suggest, has the potential to transform subjects' sense of fixed identity (either their own or others') and make them more amenable to understanding other cultures and adopting new selfhoods. The literature I examine reveals the degree to which British Romantic writers were attuned to, and invested in, debates about Greek and British national and European

\footnotetext{
${ }^{10}$ As I discuss in my chapters dedicated to Ida of Athens and The Travellers, relationships between British and Greek characters often compel the novels' main characters to question their former national and cultural allegiances and to become amenable to learning from, and adopting aspects of, the new culture to which they have been exposed. In Ida, the British Lord B arrives in Greece with preconceived notions of the country as uncivilized until he meets the impossibly transcendent Ida, who makes him reassess his opinion of - and attraction to - Greece (and Greek women). Ida, though consistent in her love for Greece, is temporarily altered by her time in Britain, though negatively, as she becomes immersed in the revelries of London high society rather than advocating for her country's independence. In The Travellers, the British Stanley Melcombe, who is at first ignorant of Greece's plight, is changed by his friendship with the Greek man Alexis Condili, agreeing to travel to Greece with Alexis to fight the Ottomans. Alexis's sister, Ianthe, though not initially interested in a romance with Sidney, grows to love the Englishman and agrees to move to England with him, where she and he can continue to promote Greek independence.
} 
collective identities. My analysis of nine British literary works written between 1809 and 1826

seeks to reveal the wide range of political and ideological positions present in the period's

literature about Modern Greece and how British writers used cross-cultural interactions to help

reinscribe and revise both Greek and British national identities.

\section{East Becomes West: Making a European Greece}

During the Romantic period, Greece was a highly contested topos in debates about Eastern and Western culture and geopolitics: many writers considered Greece to be "situated on the crossroads between the West and the East, sometimes part of either one of them, sometimes idiosyncratically standing alone" (Van Steen 171). Specifically, while Greece was geographically and politically connected to the Ottoman Empire (and thus, a part of the Eastern world), eighteenth- and early nineteenth-century European (and Greek Enlightenment) scholars began to understand and portray its ancient heritage as being historically and culturally linked to the Western world. ${ }^{11}$ European thinkers suggested that Ancient Greece had inspired everything from European literature and philosophy to education and political governance, and by the early nineteenth century the Hellenic past had become associated with Western ideals of perfectibility in arts, literature, politics, and culture. ${ }^{12}$ Early nineteenth-century Britons-i.e. scholars of Ancient Greek at Oxford and Cambridge, artists who were inspired by Ancient Greek aesthetics,

\footnotetext{
${ }^{11}$ As Gonda Van Steen writes in Liberating Hellenism from the Ottoman Empire: Comte de Marcellus and the Last of the Classics (New York: Palgrave, 2010), "Greece, one of the most contested physical and discursive domains, has been both the source and the repository of challenges to our-western - perceptions on Occident and Orient, but also on the Near East and the Balkans, on Europe, and 'everything else east and south"' (15).

${ }^{12}$ In Shelley and Greece, Jennifer Wallace writes that, "[b]y the nineteenth century, Greece had moved from the margins of culture to a central position attracting national attention. It had replaced Rome as the cultural and political model, strengthening the moral fibre of the nation from childhood" (12). Other monographs that examine the Ancient Greek "revival" in Europe include Terence Spencer's Fair Greece Sad Relic: Literary Philhellenism from Shakespeare to Byron (London: Weidenfeld and Nicolson, 1954) and Fani-Maria Tsigakou's The Rediscovery of Greece: Travellers and Painters of the Romantic Era (London: Thames and Hudson, 1981). According to Tsigakou, by the early nineteenth century "[1] gout grec was reflected in a whole range of artistic activities, in art and in literature, in furniture and the decorative arts, in costume, even in coiffure. Graecomania knew no bounds: the Greek style became a way of life" (20).
} 
and historians and political thinkers who advocated for British forms of governance that replicated those of Ancient Greece (including democracy, monarchy, and imperialism) — were integral in popularizing Ancient Greece in Europe and in supporting its integration into a Western cultural past. ${ }^{13}$

If, however, by the early nineteenth century Britons considered the Ancient Greek past as part of a Western tradition, Modern Greece was seen as anything but for a majority of British writers and travellers who "considered the Greeks from the late antiquity onwards to be 'degenerate' and 'debased'” (Angelomatis-Tsougarakis 86). Modern Greeks' corrupted character, believed to be a consequence of their rule by the Ottoman Empire and thus indicative of Greece's entrenchment in the Eastern world, became increasingly problematic for a Europe and Britain that was beginning to consider Ancient Greek society as representing the ideal (Western) civilization which all Europeans should attempt to emulate. As Paul Stock explains, “[t]he spatial politics of Greece's location—within the Ottoman Empire-affects the idea of a European tradition centered on ancient Greek civilization. Greece is simultaneously conceived as a European progenitor as well as a corrupted and alien other" (20-21). Nineteenth-century Greece presented Europe and Britain with unique cultural and ideological challenges and, as many Britons believed, if Hellenism was to become a dominant discourse in, and defining ideology for, European politics, culture, and (national) identity, both Ancient and Modern Greece

\footnotetext{
${ }^{13}$ See M. L. Clarke's Classical Education in Britain 1500-1900 (Cambridge: Cambridge University Press, 1959) for a comprehensive view of classical education in Britain. Studies in Eighteenth-Century British Art and Aesthetics (ed. Ralph Cohen, Berkeley: University of California Press, 1985) and Silvestra Bietoletti, Neoclassicism \& Romanticism 1770-1840 (New York: Sterling, 2005) discuss the influence of Ancient Greek art on British aesthetics of the Romantic period. See Kyriacos Demetriou, "In Defence of the British Constitution: Theoretical Implications of the Debate over Athenian Democracy in Britain, 1770-1850" (History of Political Thought 17.2 [1996]: 280-97) and C. Akça Ataç, Imperial Lessons from Athens and Sparta: Eighteenth-Century British Histories of Ancient Greece (History of Political Thought 27.4 [2006]: 642-60) for an overview of the multiple historical and political engagements with Ancient Greece in late eighteenth- and early nineteenth-century Britain.
} 
would need to become disentangled from the Ottoman world, geographically as well as

ideologically, a process that I argue takes places in literary culture before it does politically. ${ }^{14}$

British Romantic writers understood the high political, social, and cultural stakes

involved in contemporary debates about Modern Greece's place in the Eastern and Western

worlds, and their works became sites of theoretical and political debate about Europe's efforts to

dislodge contemporary Greece from the East and integrate the country into a Western (and thus,

European) sphere of influence. The first half of the nineteenth century was the period "during

which imperialist and nationalist forces surged, and West and East became reified structures

through a discourse that centered on the eastern Mediterranean" (Van Steen 13-14). As my

dissertation emphasizes, Greece was, even before its bid for independence in 1821, at the centre

of debates about East and West and its own place in either (or, more complicatedly, in both). My

dissertation reads a selection of British Romantic novels, poems, and travelogues as, collectively, representative of British authors' efforts to understand (Ancient and Modern) Greek culture,

politics, and identity and to intervene in this critical historical moment for Europe wherein

Greece was being transformed into a Western nation state.

\footnotetext{
${ }^{14}$ Debates about Modern Greece's integration into the West/Europe was part of a larger issue coined "the Eastern Question" by the great powers of Europe. The "Eastern Question" referred to the Ottoman Empire's so-called decline (recent scholars have debated the accuracy of this depiction of the Empire). By the late eighteenth and early nineteenth centuries, the Ottoman Empire had gone through a series of social, political, and economic transformations that left the Empire decentralized, which was considered by the strongly centralized nation-states of Europe to be a clear sign of the Empire's decline. During the Greek War of Independence, Britain's relationship with the Ottoman Empire was once again called into question as Britain had to negotiate its largely positive relationship with the Ottoman Empire with Russia and France's intervention in Greek affairs, which ultimately jeopardized Britain's power in the Eastern Mediterranean. For more on the Eastern Question, see Alexander Lyon Macfie, The Eastern Question 1774-1923: Revised Edition. New York: Routledge, 2014. Also important, as writers like Gonda Van Steen and Stathis Gourgouris discuss, the study of Ancient Greece was used by Western scholars to disconnect Greece (past and contemporary) from the Eastern world. See Gonda Van Steen, Liberating Hellenism from the Ottoman Empire: Comte de Marcellus and the Last of the Classics. New York: Palgrave, 2010; and Stathis Gourgouris, Dream Nation: Enlightenment, Colonization, and the Institution of Modern Greece. Stanford: Stanford University Press, 1996. See too Margarita Miliori, "Europe, the Classical Polis, and the Greek Nation: Philhellenism and Hellenism in Nineteenth-Century Britain." The Making of Modern Greece. Ed. Roderick Beaton and David Ricks. Surrey: Ashgate, 2009. 65-80.
} 
By focusing on British Romantic writers' portrayals of Modern Greece in the Western and Eastern worlds, I emphasize that the British Romantic era was a pivotal period not only in the "rediscovery" of a "European" Ancient Greece but also in debates about the creation of a Western-oriented, Hellenized Modern Greece (and Europe). These debates about Greek identity become especially important during the Greek War of Independence (1821-28) when British philhellenes used the Ancient Greek past as a cultural currency to help promote the Greek cause. ${ }^{15}$ I discuss the role of British philhellenism in shaping the British Government's and public's opinions about Greece's independence in greater detail throughout my dissertation, and especially in Chapters 3 and 4, but the point I want to make here is that British Romantic writers, the majority of whom supported Greek liberation, were the first to articulate the potentially troubling consequences of philhellenism and "Europeanizing" Greece.

While European philhellenism may have advanced the Greeks' desire for independence, it also altered Greek (and European) identity (a process that continues to this day to have important implications for Greece and Europe) and used the idea of "Greece" to promote

\footnotetext{
${ }^{15}$ Philhellenism — etymologically, "a love for everything Greek" — was an intellectual movement in Europe that grew, predominantly, out of an admiration for the Ancient Greek past and which was integral to Greece's eventual freedom from Ottoman rule. In Britain, public interest in the Greek War of Independence was initially low, even though "English literature had a long philhellenic tradition and the British people had a long tradition of espousing causes abroad" (St. Clair 138). Particularly hostile to the war was the Tory-controlled government - with Lord Castlereagh as its foreign secretary - which wholly supported the Ottoman Empire (Bass 48). However, following Castlereagh's suicide in August 1822 and the more liberal-minded George Canning's promotion to foreign secretary, British philhellenes witnessed and seized an opportunity to influence their government's and the greater British public's position on the Greek war. Importantly, in March 1823, the London Greek Committee, founded by Edward Blaquiere and John Bowring, issued its first pamphlet supporting the Greek revolution and quickly became "the most important philhellenic organization in the world" (St. Clair 141). Through its efforts-which included publishing Modern Greek folk songs, delivering public speeches about the war, and, perhaps most vitally, recruiting Lord Byron to become a member - the London Greek Committee influenced governmental and public opinion about the revolution, even though its members would have to wait until 1827 to see British intervention in Greco-Ottoman warfare. "The simple ideals about regenerating Ancient Greece and defending Christians against Infidels which had inspired the first philhellenic efforts on the Continent," writes St. Clair, "were now alloyed with apparently more sophisticated considerations" (140). See William St. Clair, That Greece Might Still be Free: The Philhellenes in the War of Independence. Oxford: Oxford University Press, 1972; C. M. Woodhouse, The Philhellenes. London: Hodder and Stoughton, 1969; and F. Rosen, Bentham, Byron, and Greece: Constitutionalism, Nationalism, and Early Liberal Political Thought. Oxford: Clarendon Press, 1992, which explores in depth the connection between philhellenism and liberalism.
} 
European hegemony, ethnocentrism, orientalism, and colonialism. ${ }^{16}$ Indeed, these historical developments have important implications for my project; in discussing British Romantic works that engage with Greece, I remain aware of the ethnocentric and orientalizing discourses at play in this literature, including in works supportive of the Greeks and their liberation, such as Sidney Owenson's Ida of Athens, which features a Hellenized female protagonist, Ida, whose name, dress, and education are all rooted in the Ancient past. However, as I also demonstrate throughout my dissertation, British Romantic writers did not unthinkingly replicate Orientalist renderings of Greece, but instead actively engaged with various discourses about Greek identity and problematized the ways in which British readers were to understand contemporary Greece and Greeks. In each chapter, I examine how early nineteenth-century publications reconsider past and present characterizations of Modern Greeks (as Western or Eastern; as akin to the Ancient Greeks or a debased version of Hellenes; etc.) and engage with (and confront) a British politics (often dressed up as philhellenism) that attempted to efface Modern Greek culture and to make the country submissive to Western prerogatives. ${ }^{17}$

\footnotetext{
${ }^{16}$ This is the crux of Martin Bernal's controversial 1987 study Black Athena: The Afroasiatic Roots of Classical Civilization, which posits that Ancient Greek culture had Afro-Asiatic roots as a result of Ancient Egyptians and Phoenicians having colonized Greece. Greece's Afro-Asiatic inheritance was denied, argues Bernal, by eighteenthand nineteenth-century European academics who sought to use the classical past as a political (and racist) tool to propagate an ideology of pan-European nationalism. Although Bernal's work has been discredited by scholars who have questioned his historiographical and philological approaches (as well as his lack of material and textual proof for many of his assertions), Black Athena nonetheless forced academics to reconsider the ways in which we have traditionally perceived Ancient Greece (i.e. as purely "Hellenic") and the construction of the West/Europe. See Martin Bernal, Black Athena: The Afroasiatic Roots of Classical Civilization. New Jersey: Rutgers University Press, 1987. See too Mary R. Lefkowitz and Guy Maclean Rogers (eds.), Black Athena Revisited. North Carolina: The North Carolina University Press, 1996, a collection of essays that critique Bernal's Afro-Asiatic thesis. Bernal responded to this monograph in his 2001 publication Black Athena Writes Back: Martin Bernal Responds to His Critics. See Martin Bernal, Black Athena Writes Back: Martin Bernal Responds to His Critics. Ed. David Chioni Moore. North Carolina: Duke University Press, 2001.

${ }^{17}$ For Stathis Gourgouris, philhellenism is "perhaps one of the most audacious tricks of nineteenth-century European history, drawing extensively (but also furtively) upon the most characteristic ideological industries of the period (Orientalism and philology) to constitute its discursive order" (128). For Gourgouris, philhellenes purporting to support Greek liberation merely concealed their orientalizing of Modern Greece and desire to use the Hellenic past to further ideological ends, - namely, that of a unified, hegemonic Europe - an argument that complements Edward Said's assertion that "cultures tend to make representations of foreign cultures the better to master or in some way control them" (Culture and Imperialism 100). I agree with Gourgouris's assessment, but provide nuance
} 
Albeit in very different ways and for very different reasons, all the works that I discuss in this dissertation are concerned with representing a contemporary Greece that is, even if under Ottoman rule, culturally vibrant and self-determining. All the writers discussed in this dissertation, whether they support Greek liberation or not, endorse Greeks' individual liberties in the face of both Ottoman and Western (or British) threats to personal autonomy. For example, although Hope's representation of his protagonist Anastasius as oblivious to Greeks' Hellenic past may differ from Owenson's characterization of Ida as beholden to the ancient world, thus underscoring the two authors' contrasting beliefs about Greece as being "Eastern" or "Western," both writers ultimately support Modern Greeks' ability to determine their own lives and future. Moreover, by depicting an Eastern-influenced (or non-Western) Greece, with Greeks operating within the Ottoman world, living in the Ottoman Empire, and creating a literary culture apart from Europe, writers like Byron, Hope, and Godwin use their portrayals of the Greeks to emphasize the strengths of contemporary Greek (and Eastern) culture. By focusing on the “Eastern” components of Modern Greek culture, British Romantic authors provide readers (then and now) with a glimpse of a Greek world that did not ultimately take precedence in the European imaginary - as Greece's Hellenic past became the cultural capital upon which Modern Greece and its nationalism were built—but which foreshadows Greeks' later nineteenth-century revolt against those Europeans and Greeks who attempted to efface Greece's Romaic identity by portraying the contemporary country as Hellenic. ${ }^{18}$

to it by demonstrating that British Romantic writers were aware of the problems with philhellenic renderings of Modern Greece. See Stathis Gourgouris, Dream Nation: Enlightenment, Colonization, and the Institution of Modern Greece. Stanford: Stanford University Press, 1996; and Edward W. Said, Culture and Imperialism. New York: Random House, 1993.

${ }^{18}$ Debates about Greek identity in the nineteenth century centred on language, with Katharevousa and Dimotiki being the two forms of Greek used during this period. The former was invented by Adamantios Korais in the early nineteenth century and was an archaized version of the modern language. Korais had hoped that by "purifying" vernacular Greek, contemporary Greeks would eventually learn to speak Ancient Greek and, thus, become akin to their idealized progenitors. After the Greek War of Independence, the Modern Greek state adopted Katharevousa as 
The narratives I discuss throughout the course of my study were the first to grant Modern Greeks a voice against the European imperialism and Romantic nationalism that, even if unintentionally, sought to efface the multicultural and Eastern facets of the Greek world. Of course, it is always problematic when outsiders propose to speak for any ethnic group, and my analysis throughout the dissertation is attuned to this fact. Nevertheless, my dissertation is concerned with examining the range of political and personal positions Romantic-era writers took on Greece, especially how these positions inflected their discussions about British hegemony and West-East power dynamics and contributed to the divide between East and West that became even more pronounced as the century advanced. In fact, I seek to complicate discourses around the Greek War of Independence as a liberation movement by examining how Romantic writers questioned British intervention in Greek affairs. The war created a dilemma for writers supportive of Greek freedom but critical of Britain's potential intervention in GrecoOttoman warfare, as these authors had to ensure that, in espousing Greek liberation and supporting a view of Greece as Western and/or Hellenic, they were not complicit in Europe's dismissal of Modern Greek culture. British writers were conscious of the tremendous political, cultural, and social import of Greece's liberation and I argue that Romantic-era cultural debates about Modern Greece were just as significant and prevalent as the cultural debates surrounding Ancient Greece which have, until recently, been the predominant focus in studies of British Romantic Hellenism.

its official language. Katharevousa, however, had been a controversial language from its inception, as it was a stylized form of Greek unfamiliar to most Greeks, especially those without an Ancient Greek education. As the nineteenth century progressed, more writers supported the use of Dimotiki (vernacular Greek), with Ioannis Psycharis's 1888 publication My Journey, a memoir written entirely in Dimotiki, representing a watershed moment in the legitimization of the vernacular language. The language debates continued to rage in Greece until 1976, when the Greek state formally recognized Dimotiki as Greece's official language. For more on Greek language debates, and their association with Modern Greek identity, see Peter Mackridge, Language and National Identity in Greece, 1766-1976. Oxford: Oxford University Press, 2009. 


\section{Methodology and Chapter Outline}

My dissertation rethinks British Romantic Hellenism by accounting for Britain's engagement with contemporary Greece and Greeks in the early nineteenth century. By focusing on the intercultural relationship between Britain and Greece, my dissertation contributes to an understanding of Romantic-era British literature as preoccupied with matters of global, national, and cultural significance. Romantic writers read books in many languages, learned about various cultures and histories, and were influenced by both global and local politics, and I strive to highlight these types of engagements in my dissertation. In order to better account for the complexity of British writers' treatment of Greece, I discuss previously unexamined works by both well-known and less well-known writers, often coupling these publications with canonical works. My dissertation also emphasizes how instrumental female writers were in the canon of British Romantic Hellenism, despite the fact that their male colleagues have received the majority of attention in the field. ${ }^{19}$ Many Romantic-era authors wrote about Greece-especially when we include non-fiction prose writers — and although I cannot engage with all of the works within the purview of British Romantic Hellenism, I have chosen a selection of literary works with the intention of giving readers an impression of the scope and complexity of the field.

It is important to note that my focus on British writers' preoccupation with early nineteenth-century Greece does not discount the immense influence that late seventeenth- and eighteenth-century neoclassicism and travel-writing had on the writers of the Romantic era.

\footnotetext{
${ }^{19}$ A recent work in the field which has examined female Romantic writers' contributions to Romantic Hellenism is Noah Comet's excellent Romantic Hellenism and Women Writers (New York: Palgrave, 2013). Romantic Hellenism and Women Writers demonstrates how female Romantic writers' works about Greece constituted a coherent genre of writing that had a broader influence than is customarily acknowledged. By rejecting traditionally masculine approaches to Romantic Hellenism, Comet is able to demonstrate that female Romantic writers were very much part of the Ancient Greek revival in nineteenth-century British literature, as well as responsible for Hellenism's continued popularity in the Victorian era, a fact that periodization and canonization subsequently obscured. The 2008 collection Women Writing Greece (eds. Vassiliki Kolokotroni and Efterpi Mitsi) features chapters on late eighteenth and early nineteenth century writers Lady Elizabeth Craven, Lady Hester Stanhope, Lady Morgan, and Mary Shelley.
} 
Undoubtedly, Romantic authors were aware of, and borrowed from, the works of European neoclassicists including, but not limited to, the English architects James Stuart and Nicholas Revett (The Antiquities of Athens and Other Monuments of Greece, 1762) and German art historian Johann Joachim Winckelmann (Thoughts on the Imitation of Greek Works in Painting and Sculpture, 1755). Neoclassicists like Stuart, Revett, and Winckelmann were responsible for popularizing Ancient Greek art, architecture, and culture in Europe and, undoubtedly, contributed to the Hellenic ideology that was ultimately responsible for European intervention in Greece's war with the Ottoman Empire. ${ }^{20}$ Moreover, travelogues by such European travellers as Frenchman Jacob Spon (Relation de l'état Présent de la Ville d'Athènes, 1674) and Englishman Sir George Wheler (A Journey into Greece, 1682) were the first texts to expose European readers to the Modern Greeks and encourage Romantic writers to learn and write more about Modern Greece. ${ }^{21}$ In fact, Timothy Webb argues that European travellers were pivotal in producing the intensified "interest in discovering the reality of Greece both past and present" (3) witnessed during the eighteenth and nineteenth centuries. British Romantic Hellenism is indebted to (and is in many ways an extension of) seventeenth- and eighteenth-century engagements with Greece, a point I emphasize throughout my dissertation. As Maria Schoina argues, "[t]he search for

\footnotetext{
${ }^{20}$ As early as 1946, Walter Jackson Bate in From Classic to Romantic: Premises of Taste in Eighteenth-Century England (New York: Harper, 1946) discussed the relationship between Classicism, Neoclassicism, and Romanticism, the latter of which he argues integrated and supplanted the former two. For a comprehensive list of eighteenth-century neoclassical writers, see the "Chronology" section of Timothy Webb's English Romantic Hellenism, 1700-1824. In Romantics, Rebels \& Reactionaries (Oxford: Oxford University Press, 1981), Marilyn Butler examines Romantic writers' preoccupations with the Greek and Roman past. In Chapter 5, "The Cult of the South: the Shelley circle, its creed and its influence," Butler argues that "[t]he battle in defence of the classical and Mediterranean South was stoutly fought for a decade from 1812 by a generation of liberal English writers who believed they were fighting for their political principles" (121), what Butler deems a kind of "conscious classicism" (123).

${ }^{21}$ For more on British travellers in Greece see Terence Spencer, Fair Greece Sad Relic: Literary Philhellenism from Shakespeare to Byron. London: Jarrold \& Sons, 1954; Helen Angelomatis-Tsougarakis, The Eve of the Greek Revival: British Travellers' Perceptions of Early Nineteenth-Century Greece. London: Routledge, 1990; David Constantine, In the Footsteps of the Gods: Travellers to Greece and the Quest for the Hellenic Ideal. London: Tauris, 2011; and Bernard Herbert Stern, The Rise of Romantic Hellenism in English Literature, 1732-1786. London: Octagon Press, 1969.
} 
authenticity of experience and validity in the representation of other people and places is symptomatic of a Romantic sensibility which succeeded — though not fully superseded - the rational and factual approach typical of much eighteenth-century practice of travelling and travel writing” (89). By rooting my analysis in the historical, cultural, literary, and geographical, I provide an account of British Romantic Hellenism that emphasizes the ways in which British writers engaged with a variety of discourses in reproducing versions of Greece that concretized the country. Greece is no longer merely the (imagined) topos of a glorified ancient people or of a degraded modern populace, but repositioned by British Romantic writers as a country integral to the modern, global world of the early nineteenth century.

The first two chapters of my dissertation examine works produced before the Greek War of Independence (1809-21). In Chapter One, I focus on Sydney Owenson's Woman: or Ida of Athens (1809) and Thomas Hope's Anastasius; or, Memoirs of a Greek; Written at the Close of the Eighteenth Century (1819). This chapter fleshes out previous scholarly examinations of early nineteenth-century Greek-European transcultural relations by analyzing how British Romantic writers engaged in contemporary debates about Modern Greek identity. Whereas most studies of Romantic Hellenism focus on Ancient Greece's literary and political legacy and Modern Greece's topography, I provide an extended discussion of Greek and European cultural and national identities. As I demonstrate, Owenson and Hope represent different versions of Greeks and Greece. Namely, while Owenson's Ida draws upon antiquarian notions of Greece in order to depict Modern Greek national identity and to advocate for Greek revolution, Hope's Anastasius demonstrates how portrayals of Modern Greek nationalism that draw upon Ancient Greece are fabricated and suggests instead that contemporary Greeks are unconcerned about their ancient past but rather entrenched in Ottoman society. The novels reveal both the possibilities and 
limitations inherent in intercultural relations and contributed to debates surrounding Modern Greek national identity and the ways that Europeans (and in the case of these two novels, English readers) conceptualized Modern Greece at a time when Modern Greek identity itself was in a transition (from Romaioi to Hellenes) encouraged both by European and Greek intelligentsia.

Chapter Two focuses on Byron's first trip to Greece from 1809 to 1811, during which the poet became intensely preoccupied with Modern Greek language, literature, and print culture. The chapter probes that interest by examining Byron's response to an 1810 Edinburgh Review article that begins as an even-handed analysis of Modern Greek literature but ends up disparaging Modern Greek writers and making the common claim that Modern Greek is a degenerated form of the ancient language. Although Byron's interest in Modern Greek literature and language remains a neglected aspect of the poet's work, this chapter argues that his championing of Modern Greek literature gestures toward his broader support for a stronger intercultural relationship between Greece and Britain. Further, I contend that Byron's defense of Romaic (vernacular) Greek, which comes during a period when a Hellenic model of Greece is becoming increasingly popular throughout Europe, represents the poet's attempt to move away from solely classical conceptions of Greece and to familiarize British readers with a contemporary culture with which they were very little acquainted.

Chapters Three and Four turn to literary works published during the Greek War of Independence. In Chapter Three, I analyze Percy Bysshe Shelley's Hellas, Catherine Grace Godwin's Reine Canziani, and Felicia Hemans's “The Bride of the Greek Isle.” This chapter represents an attempt to rethink nineteenth-century philhellenism by examining texts that scrutinized the efficacy of, and ideologies pushing forward, British support for Greek independence. Although all three writers employ the trope of the "captive woman," I argue that 
they do so not to conform to Orientalist readings of the East but instead to force readers to reflect upon the Western world's own treatment of Greek women. I suggest that all three writers use captive women to challenge both those Britons opposed to or apathetic toward Greek independence and national sovereignty and those who advocate a philhellenism detrimental to the Greeks because it ignores the realities of every day Modern Greek life. In Hellas, Shelley's critique of an uncritical philhellenism is made most apparent by analyzing the poem's Chorus of Greek Captive Women who adopt philhellenic rhetoric in celebrating Greece's rebirth, but who eventually realize that the ancient ideal is unattainable in the modern world. However, while Shelley rejected an uncritical philhellenism, he still believed Greece was best served by Western intervention and influences. Godwin, on the other hand, problematized European intervention in Greece by having her titular heroine Reine endure the worst mistreatment not at the hands of the Ottomans, but at those of the Englishman Monthermer, a Lord Byron type who convinces her to live together out of wedlock before impregnating and abandoning her. Godwin cuts a fine line: although she supports Greek liberation and is critical of Ottoman violence toward Greeks, her novel criticizes British liberals who purported to care about Greek liberty but who acted as salaciously and injuriously as the Easterners whom they demonized. Finally, Hemans, in contrast to Shelley and Godwin, features in "The Bride of the Greek Isle" a strong-willed Greek woman, Eudora, who refuses to be victimized and oppressed, choosing to self-immolate instead of remain an Ottoman prisoner. As I argue, Eudora's self-immolation is not only a rejection of Ottoman oppression but a jarring plot turn that forces Hemans's British readers to reflect upon their own idealized (and thus culturally ignorant) readings of the poem (and of contemporary Greece) prior to the climactic fire scene. 
In Chapter Four I turn to Tertius Kendrick's The Travellers (1825) and Mary Shelley’s The Last Man (1826). Although neither novel is set during the Greek War of Independence, I suggest that both narratives implicitly ask readers to consider what it would entail for contemporary Britain to assist Greece, for Greece to become a Western nation, and for Britain and Greece to develop closer transnational relations. In order to examine Greek-British relations of the early nineteenth century, both novelists offer personalized narratives that only implicitly comment on the 1820 s Greek War of Independence and which imagine liberation movements of the past (Kendrick) and of the future (Shelley), a decision by the authors which forces their readers to consider how the past and future inform the present day Greek war. I argue that the novels differ vastly in the ways they mediate and use Greece's Byzantine past. While Kendrick suggests that British-Greek intercultural relations can be consolidated through Britain's connection to Greece's Byzantine (and thus, Roman imperial) past, Shelley warns that such an affiliation is perilous. The Last Man's Plague that consumes the world is an indictment of GreekBritish relations which promote imperial expansion both British and Greek. My examination of The Travellers and The Last Man reveals the complicated and fascinating ways in which various personal, political, colonial, social, ideological, and economic imperatives intersected and ultimately determined British support for Greek independence.

Ultimately, this dissertation demonstrates how British Romantic literature about contemporary Greece reflects the momentous political and cultural changes occurring in late eighteenth- and early nineteenth-century Britain, Greece, and Europe. British Romantic writers were well informed about the debates and discourses concerning Greece and Hellenism, as their multiple perspectives and differing views on Modern Greece reveal. British Romantic writers did not only replicate prior discussions about the Hellenic world but imagined in their works various 
potential realities for Greece, including improved intercultural relations between Greeks and Britons. Greece was during the Romantic period, as it is now, a complicated topos that forced British writers to reassess their understandings of East and West, European identity, and Western culture. And while we may believe that it was later scholars who exposed the political and cultural dogmas that contributed to the rise of Hellenism in the late eighteenth and early nineteenth centuries, my dissertation demonstrates that British Romantic writers were already attuned to and critical of ideological uses of Greece — both as an idea and a real place — during their own time. 


\section{Chapter One \\ Caught Between East and West: Negotiating Modern Greek Identity in Ida of Athens and Anastasius}

\section{Introduction}

In Richard Polwhele's 1799 poem Grecian Prospects a Welsh bard journeys through Greece, reflecting on the country's past and lamenting that its ancient glory is gone. Inspired by the strong feelings his meditations on Ancient Greece have produced, the speaker imagines a Greek landscape wherein “Apollo's form still glides, unconscious, by" (27) and "Phidias breath'd from every nich" (30). Midst his contemplations, however, the poet hears "a scream of wild distress" from a Modern Greek being murdered, which forces him to reconsider his idealized vision of Greece in a "pale cold shade" (31). This moment awakens the bard to the struggles of the Modern Greeks and he considers, in the remainder of the poem, how they can become liberated from the Ottomans. According to the speaker, the Modern Greeks, though currently subjugated, have been awaiting the moment to seize their freedom: “Thus the chain'd eagle, tho' he seem subdued, / Yet, some propitious moment, breaks away, / Soars thro' the severing clouds, and drinks the golden day" (35). Importantly, the speaker suggests that, if Britain were to help Greece, the Modern Greeks would become liberated and able to recapture their former glory. The Greeks would no longer "idly pant for all their former praise," the speaker declares, "[i]f Albion's orb effuse its fostering rays" (43).

Certainly, there was reason enough in 1799 to think that Greece might become free from Ottoman rule. In the late eighteenth century, Greeks initiated several revolts against the Ottomans, the two major of which were the Orlov Revolt (1770) that transpired in the Peloponnese during the Russo-Turkish War of 1768-74, and another uprising which began in 
1788 under the command of the corsair Lambros Katsonis during the Russo-Turkish War of 1788. ${ }^{1}$ Although the Orlov Revolt and Katsonis's piratical activities ultimately failed to secure Greek freedom from the Ottoman Empire- the Ottomans, with the help of an Albanian soldiery, quickly suppressed the former (Dakin 26) and combined French and Ottoman forces quelled the latter in 1792 (Greenhalgh and Eliopoulos 140) - they nonetheless made Europeans take notice of Greeks' desire for independence and inspired many works about the prospect of a future liberated Greece.

Nevertheless, the speaker's proposition that the British assist Greece in becoming independent from the Ottoman Empire, though a seemingly typical response, was in fact quite a provocative suggestion, as Britain was allied with the Ottoman Empire in the late eighteenth century. Polwhele's speaker's proposal, I argue, reflects the fact that dramatic political and social developments taking place between Greece and Europe during the late eighteenth and early nineteenth centuries prompted Britons' growing knowledge about, and even concern for, the everyday lives of Modern Greeks. As I discussed in the Introduction to my dissertation, there were many reasons (in addition to Greece's failed uprisings) for the suddenly greater presence of Greece and Modern Greeks in European and British discourses of the Romantic period: increased Greek mercantile activity and trade in Europe; diasporic Greeks studying at European universities and establishing communities in various European cities; and, as Polwhele's poem alludes to, Mediterranean geopolitics. Indeed, when Polwhele published Grecian Prospects,

\footnotetext{
${ }^{1}$ The Orlov Revolt saw the Russian brothers Theodore and Alexander Orlov join forces with two legions of Greeks (1200 from Mistra and 200 from Kalamata). Douglas Dakin writes of Katsonis that he "assembled a Greek pirate fleet of some seventy vessels which harassed the Turkish squadrons. In February 1790 Katsonis engaged with the Turkish fleet at Kafirea. Three thousand Turks perished" (27). Will Smiley adds that "Katsonis switched back and forth between 'legitimate' and 'illegitimate' raiding, continuing to fight, as an outright pirate, after the Russian state disavowed him in June 1792" (224). See Douglas Dakin, The Greek Struggle for Independence 1821-1833, Berkeley: University of California Press, 1973; and Will Smiley, “'After Being So Long Prisoners, They Will Not Return to Slavery in Russia': An Aegean Network of Violence between Empires and Identities," The Journal of Ottoman Studies XLIV (2014), 221-34.
} 
Britain was becoming increasingly concerned that France-which under Napoleon had launched a campaign to capture numerous European and North African territories, an operation that forced Britain into what would become a two-decade long war (1803-15) — and Russia would monopolize the Mediterranean region, and one can read in his suggestion (that Britain aid Greece) a resistance to French and Russian intervention in the Mediterranean area.

Various Romantic-era social, political, and cultural factors forced Britain into closer contact with Greece and Polwhele's remarkably early advocacy for Greek-British relations, I suggest, foreshadows the proliferation of British responses to developments occurring in Greece in the first years of the nineteenth century. In this chapter, I want to focus on arguably the two most popular British novels from the first two decades of the nineteenth century (published before the Greek War of Independence) which responded to Britain's newfound interest in contemporary Greece, with an eye to Greeks' possible emancipation and closer relationship with Europeans: Anglo-Irish writer Sydney Owenson's sentimental national tale Woman: or Ida of Athens (1809) and Anglo-Dutch author Thomas Hope's Orientalist picaresque Anastasius; or, Memoirs of a Greek; Written at the Close of the Eighteenth Century (1819). These two novels offer vastly different representations of Modern Greeks and the prospect of an emancipated Greece. While Owenson's Ida draws upon antiquarian notions of Greece in order to depict Modern Greek national identity and advocate for Greek revolution, Hope's Anastasius demonstrates how portrayals of Modern Greek nationalism that draw upon Ancient Greece are fabricated and suggests instead that the Modern Greeks are unconcerned about their ancient past and too embedded in Ottoman society to become independent. Or, in other words, while Owenson depicts a Hellenic Modern Greece, Hope demonstrates why doing so is socioculturally flawed and politically problematic. 
These disparate renderings of Modern Greece and Greeks are important for revealing to readers the range of views about Greece's relationship with the West and potential Europeanization but should not distract us from the fact that Owenson and Hope perform similar types of cultural analyses in their novels. As I discuss in this chapter, Owenson and Hope examine the complexities of Modern Greek character and contribute to early nineteenth-century discussions about Greece by portraying Modern Greeks vis-à-vis European characters and ideas. In their novels, Owenson and Hope demonstrate how Modern Greek national identity is negotiated and altered through cross-cultural interactions with non-Greeks and, in the case of Anastasius, Western-influenced Greeks. As I show, Ida's resistance to the British Lord B and Anastasius's rebuffing of his Western-educated Greek friend Spiridon demonstrate that Modern Greek identity could be formed both through acceptance and rejection of Western ideas and values. Both Owenson and Hope insist upon the importance of Modern Greeks' participation in the reconstruction of their national identities and argue against foreign hegemonic impositions on Greeks. By revealing both the possibilities and limitations inherent in intercultural relations, Ida and Anastasius contributed to early nineteenth-century debates concerning Modern Greece during a period in which Modern Greek identity itself was transitioning from Romaic to Hellenic, as encouraged both by European and Greek intelligentsia. ${ }^{2}$ If, as Homi Bhabha argues, “subjects [are] formed 'in-between,' or in excess of, the sum of 'parts' of difference (usually intoned as race/class/gender, etc.)" (2), cultural contact between Greeks and Westerners (or

\footnotetext{
${ }^{2}$ Beginning in the late eighteenth century, increasingly more Greeks and Europeans began to consider the Greeks to be Hellenes (ancestors of the Ancient Greeks) rather than Romaioi (members of the Eastern Roman Empire). Although the notion of "Hellenic" Modern Greeks was far from uniform throughout Ottoman Greece, Katie Trumpener argues that Hellenic identity reflected the fact that "Greeks came to understand themselves both as members of a shared national culture and as bearers of an illustrious national history. This new sense of history and collective identity, in turn, gave them a new belief in their political agency" (24). Although this chapter does not focus specifically on the transition from Romaioi to Hellenes (more will be said about this change in the next chapter), I argue that comparing Ida and Anastasius helps us better map late eighteenth- and early nineteenthcentury British views of and responses to Modern Greece and the interplay between the classical and the contemporary in forging Modern Greek national identity.
} 
Western-influenced characters) in Ida and Anastasius represent the ways in which Greece's intercultural relations with the European world could transform Greek identity, resulting in new geopolitical and cultural realities for both Greeks and Europeans during the Romantic period.

\section{Ida's Bicultural Identity}

"I am getting on famously with my new work; there is but one defect in it, namely, I cannot read a line of what I have written,- - I wrote in such a furore of authorship!"

(Sydney Owenson to Miss Featherstone) $^{3}$

“'At that time,' continued Lady [-], 'all the world were engaged in reading Ida of Athens. I think it was likely to please a vivid imagination, but would displease the matter of fact reader. The language is, in my opinion, pedantic, and fatigues the eye and ear with a constant glitter of high flown words; though some parts of it are doubtless very beautiful. But the sentiments are so bedizened with tinsel that they are hardly to be made out."

(Lady Charlotte Bury) ${ }^{4}$

Following her wildly popular The Wild Irish Girl (1806), an epistolary novel in which Owenson details painstakingly Ireland's antiquity as a form of resistance to English imperialism and promotes a more mutually beneficial relationship between Ireland and England (represented by the Irish princess Glorvina's marriage to the Englishman Horatio in the novel's conclusion), Owenson was compelled to write another story about national independence. Mary Campbell comments that William Gell (one of the leading archaeologists at the time) gave her the idea to write about Greece: “At a party of Lady Donegall's they had a long discussion about this, and he drew her a plan of Athens, and suggested books to study. Lady Charleville . . . lent her some prints and views of Greece, and encouraged her with benevolent patronage, and endless letters" (87-88). These sources, along with the many travelogues she read—including Jacob Spon's Voyage d' Italie, de Dalmatie, de Grèce, et du Levant (1678) and Pierre Augustin Guys's

\footnotetext{
${ }^{3}$ Sydney Owenson, "Letter from Sydney Owenson, afterwards Lady Morgan, to Miss Featherstone. 13 Oct 1807," Lady Morgan's Memoirs: Autobiography, Diaries and Correspondence, Ed. W. Hepworth Dixon, Vol. 1, London: William H. Allen \& Co, 1862, p. 309.

${ }^{4}$ Lady Charlotte Bury, The Diary of a Lady-In-Waiting, Ed. A. F. Steuart, Vol. 2, London: Lane, 1908, p. 114.
} 
Sentimental Journey Through Greece (1772)—prepared Owenson to write a narrative in support of Greek independence. Not having travelled to Greece herself, Owenson adopted a technique for writing about the country which became commonplace throughout her career: she created a heroine whom she equated with the nation, in this case Ida Rosemeli, daughter of the Athenian archon Jani Rosemeli.

From the outset of $I d a$, Owenson portrays Modern Greek identity through a British gaze, with readers being introduced to Owenson's titular character, the Archondessa Ida Rosemeli, through the eyes of English traveller and diplomat Lord B, from whose perspective the novel's first volume (of four) is narrated. ${ }^{5}$ Arriving in Greece from Venice, Lord B aimlessly wanders the streets of Athens, only to stumble upon a "luxurious garden" which is "[s]heltered by the fragrant summit of Hymettus towards the east, commanding a view of the savage rocks and towering fortress of the Acropolis to the west, and bathed by the incursive waters of the Engia" (1.8). This garden is attached to a large building which is "erected of the finest specimens of the school of Phidias" and surrounded by "beautiful metopes" and "mutilated statues" (1.8). Curious about the interior of this fascinating building, the Englishman enters and sees a young girl sleeping on a sopha:

She resembled, as she lay, the beautiful personification of Bashfulness by Corradini ... There was something so delicate, so ideal in her form, that the very drapery that veiled it seemed to partake of its aerial character; and her gently

\footnotetext{
${ }^{5}$ The name Lord B is a happy coincidence, as Owenson had published her novel in 1809, three years before Lord Byron's publication of the incredibly popular Childe Harold's Pilgrimage, a text I discuss in Chapter Two. Mary Campbell does note, though, that Owenson had encountered a 20 year old Lord Byron at a London social event in 1808. Owenson reported that " " $\mathrm{h}] \mathrm{e}$ stood with his arms crossed and alone, occupying a corner near the door, and though in the brilliant bustling crowd was 'not of it'. 'How do you do, Lord Byron', said a pretty sprite of fashion. I was then ignorant that the young and beautiful inheritor of the historic name was to give it greater claims to the admiration of posterity"' (Campbell 87).
} 
languid respiration alone, spoke her not a thing which fancy only had embodied.

It was impossible to mistake the bella reposa. - It was an Athenian girl. (1.10) By introducing Ida by way of a Western traveller in search of antiquities, Owenson invites her readers to perceive the young woman through a classical lens, even if Lord B's ekphrastic perspective of Ida and Greece is portrayed as colonialist later in the novel. In fact, like the goddess Pallas Athena, the Greek girl is the centrepiece of an antique building, one that in Ida is certainly meant to resemble the Parthenon of Phidias with its "metopes" and "statues."

Owenson's allusion to Antonio Corradini's neoclassical sculpture (most often referred to as "veiled truth") contributes further to Ida's antiquation and to readers observing her as a perfect embodiment of a modern antiquity.

Owenson continues to draw from classical notions of Greece in order to sketch Ida's identity in the novel by providing details about her heroine's lineage. Stamati, a Greek friend of Lord B's, tells the Briton that her father Jani Rosemeli "is of the archontic family of the Benengeles, which, with the exception of the house of the Lembona, is the most ancient and illustrious in Athens" (1.17). Ida's first name too, we learn, is of Ancient origin, collapsing "symbolically the difference and distance between ancient and modern Greece" (Sifaki 66). As her Greek-British uncle and preceptor (whom I soon discuss in greater detail) tells her future lover Osmyn: "'It is not a common, but an ancient name in Greece ... and was borne by the wife of Lycastus and the mother of the Cretan Minos" (2.108). ${ }^{6}$ Not only does Ida resemble a classical figure, but she is in fact genealogically Ancient Greek, a point that her behaviour throughout the novel reflects and confirms, including performing at one festival "the dance of Ariadne" (1.65) and at another "indulg[ing] her classic fancy in assuming a costume purely antique; such perhaps

\footnotetext{
${ }^{6}$ Two sacred mountains in Greek mythology are also named Ida — one in Crete (in which Rhea hid Zeus from his wrathful father) and the other in Troy. Ida was also the name of the nymph of Mount Ida in Crete who cared for the infant Zeus. See Robert Graves, The Greek Myths Graves, 2 vols, New York: George Braziller, 1957.
} 
as Aspasia wore when Pericles dictated the laws of an empire from her boudoir, or when Socrates imbibed his eloquence at her feet" (1.144-45).

It is immediately clear to readers that Owenson draws upon European neoclassicism for her portrayal of Ida's character. Just as she had done in The Wild Irish Girl, Owenson in Ida constructs an antiquarian heroine whose identification with her country's ancient past acts as a form or resistance to an imperial power (the Ottoman Empire). Indeed, in its review of the novel, the Monthly Review notices the Irish-Greek parallels and remarks that "the Archondessa is only the Princess of Inismore with a new title and a more highly cultivated mind" (198). So, whereas Owenson has Glorvina play the harp to combat England's appropriation of the instrument and to "feminiz[e] the Bardic figure and injec[t] it with more progressive strains" (Donovan 21), she has Ida play the lyre as a form of bardic resistance. Ida's lyre-playing is only appropriate as "[t]he ideal classical form of music was manifested in the lyre" (Donovan 171). To be sure, Owenson notes while Ida is playing and singing, "[i]t is supposed that something of the ancient Greek song is still to be traced in the popular airs of the modern Athenians" (1.27).

The parallel between Ida's lyre-playing and Glorvina's harp-playing is also significant because, as Trumpener argues, "bardic performance binds the nation together across time and across social divides; it reanimates a national landscape made desolate first by conquest and then by modernization, infusing it with historical memory" (xii). By playing the lyre, Ida reminds her listeners of Greece's glorious past and inspires them to think about their shared Greekness (and, eventually, to unite in the cause of liberation). Indeed, even Lord B, an English diplomat residing in Venice, and from a nation which for Owenson symbolizes imperialism par excellence, is transformed by Ida's performance: "The diadem of rank, the applause of a senate, the power of opulence, the influence, the prejudices, the habits of artificial life, fled like the idle pageantry of 
a feverish dream. Nature resumed her influence over his being, and Ida rushed to his imagination, possessed herself of his heart, and reigned alone over his thoughts" (1.70). Ida forces the English Lord B to reevaluate his priorities, culminating in the young Greek woman "posses[ing]" and "reign[ing]" over the Englishman. The conquered becomes the conqueror.

In the first volume of $I d a$, Owenson establishes a connection between Britain and Greece through antiquarianism, portraying a classical Greek heroine who appeals to the novel's British protagonist (and, the author hopes, to her readers). In volume 2, Owenson further reinforces the connection between Greece and West when she proposes that Britain is integral to establishing a newly-formed Modern Greek identity. In this volume Owenson provides readers with a backstory for Ida's Greek-British uncle that demonstrates the ways in which Britain contributes to Ida's national identity and patriotism. Ida's uncle, Owenson tells us in an extended analepsis, is the younger of two Smyrniot-Greek sons who was "[b]rought up amidst the lovely shores and lovely forms which the enchanting shores of Asia Minor so frequently possessed" (2.9) until his thirteenth birthday, at which point he moves to England to become educated (he also has property there, benefitted upon him by an uncle). Bringing with him to England a love of nature, in which he finds "the principle of love, of wisdom, and felicity" (2.11), Ida's diako soon becomes attached to his life in the foreign country:

His property rivetted him to England; and he soon became bound to it by a stronger tie than that of interest. His mind devoted to the philosophy of nature, his heart formed for the generous feelings of friendship, and the whole force and energy of his being tending towards the most overwhelming passion of the human heart, estranged from general society, by delicacy of constitution, by habits of 
study and reflection, he became the most generous, the most affectionate of

friends, to a man of brilliant talent, who had been his preceptor at College. (2.14)

Owenson portrays Ida's uncle as both a Rousseauian man of nature and feeling and a scholar who has obtained a university education. Ida's uncle's love of nature, it is clear, began in Greece where "[n]either compelled to work nor obliged to study, the free, the joyous sports of youth were only interrupted by a constitutional propensity to indolent repose and pensive meditation" (2.10). However, the way Ida's diako uses his devotion to the natural world to develop a "philosophy of nature" and a political ideology is contingent upon his formal education in England. Smyrnian-Greek nature and English education blend to form Ida's uncle's bicultural mind, though the combination of the two is not initially easy for the diako to rectify, Owenson telling us that "the sharpness of a chill northern climate began an early ravage" on the diako's "eastern constitution" (2.11). Ida's uncle must learn to combine his "eastern constitution" with his English education in order to create a new Greek (national) identity, an important point as "diasporic Greeks were the ones who played a key role in the forging of the national dream" (Hamilakis 107).

Significantly, it is the diako's bicultural experiences which inform his view (during an eight year voyage through Europe following his stay in England) that the "misery and error" (2.14) and "moral disorder" (2.14) he finds in European society result from governments disregarding nature and which inspire him to better his country by mentoring his niece to become a nationalist inspired by the example of Ancient Greece. The diako's desire to use Greece's classical past to impart a nationalist Greek character on his niece is nurtured by both his "eastern" and "northern" (western) experiences. Indeed, as Owenson tells us of the diako's feelings of despair following his eight year journey: "[Y]et he remembered the wisdom and 
happiness of ancient Greece, and he looked forward to the enlightened felicity of modern Europe" (2.16). Here, Ida's uncle connects a classical education with Europe's "enlightened felicity," revealing how the author herself uses neoclassicism and the (emerging) ideology of Hellenism to garner support for Modern Greek independence.

Returning to Smyrna after his European travels, and finding none of his family there (his parents have died, and his brother has become a merchant in Constantinople), the diako decides to find his sister, who has married an Athenian archon and moved to Athens. The diako's reaction to travelling to Athens is telling:

With a thrill of delight he believed himself incapable of feeling, he embarked on the Archipelago for Athens- that region of genius! of heroism and the graces! whose government had once been the wisest, whose people had once been the happiest, because its laws and its religion tended to confirm the impulses of nature to liberty and pleasure, to preserve the sacred rights of humanity, to diffuse equally the privileges of denization, and to distinguish the citizen only by the benefits he conferred on the community. (2.18)

For the diako (and for Owenson) ancient Athens represents an ideal society where liberty, rights, and equality prevail, privileges he hopes will extend to modern times, and not only for Greeks, as Owenson's use of the term "denization" suggests. Indeed, it is with these feelings—feelings, we should note, that only a classical education could produce, as the Athens of the early nineteenth century was a relatively insignificant provincial town - that the diako travels to the ancient capital, meets his brother-in-law and niece Ida (his sister has died), and decides to adopt his 
niece. ${ }^{7}$ Ida's uncle provides his niece with an education that nurtures both feeling and intellect and that is also, quite noticeably, focused on helping her to develop a national consciousness. Ida's diako teaches his young ward to become a patriot by, foremost, admiring Greece's nature, which includes its "naturalness" (or lack of artificiality) and natural setting. As Owenson writes, Ida's diako establishes "the basis of her education, in an observance of the laws, operations, and forms of nature" (2.35-36). However, Ida's patriotic education would be incomplete without a study of Greece's ancient past, a knowledge of which Ida's diako obtained through his British education. Ida's reverence and strong feelings for nature are politicized by being combined with a practical education:

But while she perused with curiosity, and with that insatiate love of knowledge which her early habits had inspired, the history and laws of other countries, it was the history of her own, its heroes, its patriots, its philosophers, and its artists, that engaged her mind - interested her feelings - that warmed her imagination, and influenced her enthusiasm. (2.37)

Ida is not only fascinated by learning about Ancient Greek history, though, but also enthusiastic about teaching her fellow Greeks about their past: "[S]he was wont, at the celebration of a festival, or in the repose of her domestic shades, to assemble round her her young compatriots to detail to them the ancient glory of their wondrous nation; and all its arms achieved, and all its genius compassed" (2.42). Ida also composes patriotic poems in Romaic (or vernacular) Greek.

It is by instilling in Ida a love for nature and for the classical past that her uncle makes the young girl a patriot. Ida's desire for national emancipation comes, then, as a result of the

\footnotetext{
${ }^{7}$ As Paul Sant Cassia and Constantina Bada write in The Making of the Modern Greek Family: Marriage and Exchange in Nineteenth-Century Athens (Cambridge, Cambridge University Press, 2006): "For most of the eighteenth century Athens, while an administrative centre, was in effect much like a large village. It lacked the necessary military and commercial might to completely dominate the countryside to which townsmen regularly fled in search of less oppressive conditions" (27).
} 
convergence of two cultures: Greek and British. In fact, as Owenson emphasizes, Ida's education is singular: "She only of all her countrywomen had learnt to think for herself; she alone had the benefit of an education that rendered her distinguished and unrivalled" (2.41). The conclusion that readers should draw here, I suggest, is that only a Greek (and a female at that) who has Ida's unique education is capable of being an effective patriot. What Owenson emphasizes, I go on to argue, is the importance of transcultural interactions in producing new nationalisms and in spurring revolutions that restructure the geopolitics of Greece and, thus, of Europe.

\section{The Advantages and Drawbacks of Transcultural Relationships}

In Romantic 'Anglo-Italians,' Maria Schoina examines how British literature and art about Italy were also often "keyed to various British concerns" (4) and thus ended up (implicitly and explicitly) representing both Italy and Britain. As a result, Schoina argues, these works which are "infused with elements from both cultures and mentalities ... confront each other in fanciful ways and re-imagine/re-negotiate their borders, differences and affinities" (23). ${ }^{8}$ According to Schoina, British art and literature about Italy allows British artists to consider how their nation is associated with another in ways that allow them to collapse the geographical space between "them" and "us" and to re-imagine political and social similarities and differences. Indeed, as Schoina argues, British works about Italy create "hybridised spaces" which "configure alternative geographies of spaces and identities" (24).

In $I d a$, Owenson creates a Modern Greek heroine who is formed from both British and Greek cultural elements in order to encourage readers to envision a Greek-British relationship in

\footnotetext{
${ }^{8}$ With Ancient Greece, there was the added fact that it was always already conceived of in relational terms, as so much of Greece was approached via the Roman world. Plutarch's Parallel Lives, which presents biographies of ancient historical figures in pairs (one Greek, one Roman), is an early example of a text that views Greece relationally. See M. L. Clarke, Classical Education in Britain 1500-1900, Cambridge: Cambridge University Print, 1959.
} 
which both countries "re-imagine/re-negotiate their borders, differences and affinities." As Ina Ferris notes, Owenson was a liberal and Jacobin-influenced writer whose writings about universal rights, liberty, cosmopolitanism, and patriotism were "grounded in texts and in the example of the French Revolution" (91) and in Ida she uses her own learning to create characters (Ida, Ida's diako, and later, Osmyn) who reflect her belief about the ability for transcultural interactions to reinscribe national identities and to produce free nations. Perhaps more interestingly (and radically), Owenson insists, as an Anglo-Irish woman critical of English foreign policy, that England itself might contribute to the freedom of other nations by becoming "hybridized" with other countries. After all, Ida's patriotism, a product of her Greco-British education, inspires her lover Osmyn's Athenian revolution (which ultimately fails).

Despite her enthusiasm for the possibilities entailed by transcultural interactions, though, Owenson was acutely aware of how dominant countries exploited less powerful ones. Of course, in Ida the main antagonists for the Greek characters are the Ottomans who operate as officials for the Ottoman Empire. However, in general, Owenson's portrayal of Turkish characters is reductive (i.e. they are villains) and she does not analyze in any real depth the intricacies of Ottoman-Greek relations. Rather, Owenson is interested in examining the power dynamics of, and new national identities produced by, Greek-English relations. Owenson criticizes the way English characters mistreat Greeks and how English culture has a potentially corrupting influence on her young heroine in order to comment more broadly on the ways in which dominant countries attempt to inundate the national identities of people from smaller nations. ${ }^{9}$

\footnotetext{
${ }^{9}$ What started out as a concern for her native Ireland became for Owenson a lifelong concern about imperialist hegemony and the destruction of traditional cultures. Owenson's personal investment in Ireland's sovereignty informs her position on Greece (and later, India [The Missionary: An Indian Tale, 1811], France [France, 1817], and Italy [Italy, 1821]) and demonstrates how, for Owenson, liberal politics transcend geographical, political, and cultural borders.
} 
Owenson develops her most obvious criticism of England through her examination of Lord B. As I discussed earlier, volume one of Ida provides readers with Lord B's perspective of the young Greek girl. Upon first seeing Ida (in her Corradini-like repose), Lord B is infatuated by and physically attracted to the Greek girl and ignores her intellect. Owenson writes that " $[\mathrm{t}] \mathrm{he}$ philosopher would have found the genius of Greece in her study of nature every where revealed, every where unrestrained: the patriot would have sought it in the freedom of her government, and the happiness of her people; the man of pleasure believed it existed only in the beauty of her women" (1.13). Here, Owenson offers a short, but scathing, critique of the superficial way in which British travellers (and perhaps some of her readers) interact with foreigners. While Lord B has an opportunity to see the "genius of Greece" in its (ancient) nature and government, he instead observes it only in the country's modern-day women. Lord B's lust makes him completely oblivious to Greece's ancient past and thus, for Owenson, unable to understand the struggles of contemporary Greece.

More than that, when Lord B has the opportunity to discover Greece's history through his interaction with the beautiful and educated Ida, he is unable to do so because he is troubled by the fact that Ida is both attractive and intelligent. As Owenson relates of Lord B after his friend Stamati tells him that Ida's "extraordinary learning" (1.16) far outstrips her beauty: "[T]he smile of the Englishman disappeared. It was impossible to associate the idea of a 'learned lady' with the beautiful, the indolent, the pleasure-breathing Greek" (1.17). And again later, when the Greeks are discussing Grecian politics, Lord B is anxious that Ida will join the conversation and expose her intelligence: "Mean time, he trembled lest the learning and cleverness of Ida should betray themselves in the course of the political discussion, lest an axiom should banish a grace, or an argument disfigure a feature. Genius, feminine genius, the offspring of warm feelings and 
brilliant fancy, he adored in woman, but at pedantry he shuddered" (1.23). Lord B's misogynistic attitude and lack of a classical and contemporary Greek education ensures that he never goes beyond the level of tourist during his time in Greece. All that he is interested in is the "beauty" of Greek women, as his ekphrastic voyeurism of Ida at the beginning of the novel reveals.

Evgenia Sifaki writes that " $[w]$ ithin the framework of this subplot it is possible to discern a symbolic resistance to English male presumptuous authority, which pervades the whole novel" (65). In fact, Owenson even goes as far as to link Lord B's attraction to Ida with British appropriation and imperialism of other countries (and thus to evoke the common trope of imperial "male" and colonized "female"). ${ }^{10}$ Although a "[d]isease of mind, and something of classic curiosity drove him to Athens" (1.38), Lord B is compelled to remain in Greece by Ida herself. As he tells her: "“['T] is not the works of Phidias that will now detain me in Athens; 'tis that which formed the inspiration of his genius, 'tis that which, in giving him a model for divinity, caused the deity it represented to be forgotten"” (1.39). Lord B sees Ida as "a model of divinity" and an aesthetic object to be beheld, an assessment that Owenson ensures is not read as complimentary, as the Greek woman immediately following this statement "draw[s] her veil more closely round her" (1.39). Lord B's desire to possess Ida is made even more apparent when he asks her to move to London with him: "“Let others ravish from your country the ruined fragments of its former glory, but for me, oh! be it still reserved to bear a nobler prize, and shew

\footnotetext{
${ }^{10}$ In Orientalism: Western Conceptions of the Orient (London: Penguin, 1978), Edward Said writes that the relationship between dominant Western men and submissive Eastern women "fairly stands for the pattern of relative strength between East and West and the discourse about the Orient that it enabled" (6). Others books that discuss the sexual politics of imperialism and colonialism include Anne McClintock, Imperial Leather: Race, Gender, and Sexuality in the Colonial Contest, London: Routledge, 1995; Inderpal Grewal, Home and Harem: Nation, Gender, Empire and the Cultures of Travel, Durham, NC: Duke University Press, 1996; and Feminism, Literature and Rape Narratives: Violence and Violation, Ed. Sorcha Gunne and Zoë Brigley Thompson, London: Routledge, 2010. In a different context, Roland Greene's Unrequited Conquests: Love and Empire in the Colonial Americas (Chicago: University of Chicago Press, 2000) argues that colonial encounters in the Americas replicate early modern European love poems in that a male explorer experiences his relationship with colonial territories just as would a male poet who continuously, and without ever being truly satisfied, pursues a female who remains unattainable.
} 
the lovely inspiration from whence Athenian genius drew its splendour!'” (1.77). While other travellers will "ravish" Greece's ancient ruins, Lord B wants to bring home (and presumably ravish) a different sort of relic: an actual Greek woman.

By introducing the character of Lord B to her novel, Owenson demonstrates her understanding of the shortcomings of, and power dynamic inherent in, intercultural interactions. Despite Ida's character having been influenced by both Greek and English cultures, she is still for the imperialist Lord B an object to be conquered rather than an equal to be respected. Although Ida might feel that she and her country are more compatible with the West rather than with the Ottoman East, English people like Lord B are not prepared to accept Greeks like Ida. Indeed, Ida's lack of equality with the English becomes even more apparent for her when in volume 4, after fleeing from Greece to England to escape the disdar-aga (to whom she had been betrothed), she encounters in London the same kind of cultural inequity she had experienced with Lord B. Though she is able initially to navigate the corrupting influences of the city and retain a sense of her Athenian self amidst the chaos of London, Ida quickly succumbs to London life, namely after she becomes "the most oppulent [sic] heiress in England" (4.145) following her uncle's death. As Owenson writes, "Ida creating universal amazement and admiration by the singularity of her manners, the attic delicacy of her wit, and the beauty of her person, daily attracted the world to her solitude, until led away by the ambition which grew with what it fed on, she was attracted from her solitude to the world" (4.150-51). Ida spends her inheritance on parties and becomes “an object the most novel” (4.155) for London's elite who see her as a curiosity and as a desirable marriage prospect. Ida's national identity and patriotism (which Owenson in the novel frequently terms "genius") is challenged by a commercial and superficial 
city "in which the feelings themselves were subject to the laws of calculation, and where the oppulence [sic] that rewards cannot inspire genius" (4.182).

Those facets of Ida's life which in volume one were the main identifiers of her national identity, and thus of her patriotism, become subsumed by British consumerism in London. For example, Owenson tells us of Ida's home that "her apartments blended in their appearance all that was most approvable in the ancient and modern greek [sic] and Turkish furniture, and her boudoir in England was the exact representation of her gymnasium in Athens" (4.150). Though Ida fashions her London home to look like her Greek one so as to feel better connected to her national identity while she is abroad, she also inadvertently makes herself and her ethnicity a sort of commercial curiosity for the English visitors- "those whose rank sanctioned their intrusion" (4.151) — to her home. As Silvia Bordoni argues, "[1]ike the Metopes of the Parthenon brought to England by Lord Elgin, Ida becomes a sort of tourist attraction, displaying her Greekness to satisfy English aristocrats, who see in her a symbol of exoticism brought inland from abroad" (8). The cultural identifiers that bolstered Ida's national and patriotic identity are in danger of becoming mere tourist attractions as Ida allows her life to become one of luxury rather than one dedicated to helping liberate her country. As she did in her portrayal of Ida and Lord B's friendship earlier in the novel, Owenson once again scrutinizes the effectiveness of Greek-British relations in helping Greeks to become part of a European sphere of influence, and thus to become free from the Ottomans. The English, it seems, merely value Ida because they are curious about her foreignness, and have no real desire to assist the Greeks become liberated.

Ida's only choice, then, is to abandon England, something she decides to do when she becomes reacquainted with Osmyn, who arrives in London as a decorated Russian officer (Russia, we should note, was in 1809 the country most willing to help liberate Greece, albeit for 
its own political benefit). With Osmyn's arrival in London, Ida understands how superficial her life has become and how isolated she is from her Greek compatriots and national identity. As she had done in her earlier The Wild Irish Girl, Owenson portrays London as the site of cosmopolitan consumption that is associated with the loss of national and regional identities and traditions. Once she is reacquainted with Osmyn, Ida rediscovers the patriotism and desire for national liberation taught to her by her diako, which culminates in her marriage to her Greek lover and relocation to Russia. Even though Ida is not able to convince the English to support Greek liberation during her time in England, the fact that her patriotism and revolutionary resolve is ultimately strengthened by her experiences in London is yet another way in which Owenson demonstrates how transcultural interactions shape European nationalisms. Moreover, although Sifaki rightly argues that volume four "implicitly but insightfully hints at the fact that the struggle of the oppressed for a desirable and respectable identity finally takes place inside the terrain, under the gaze and with the criteria of the oppressor" (73), we should not ignore how Ida transforms her British acquaintances and shapes revolutionary spaces within England. Indeed, although she is a curiousity in London high society, Ida's naturalness “operated like a spell on her auditors" (4.160). The young Greek woman's "habits and tastes of her early life" (4.155) appeal to her British acquaintances who want to learn more about them. And once Ida becomes aware of Osmyn's presence in London, she makes it her mission to introduce revolutionary ideas into London high society: "Wherever she was admitted, she talked of Russia, of the empress, of Potemkin, and Suvaroff' (233). While Lord B threatened to alter Ida's identity during his time in Athens, Owenson demonstrates that Ida is capable of turning the tables and, in her small but powerful way, of introducing the cause of Greek revolution to Britain. 
Even so, Owenson's novel seems in its conclusion to dismiss the efficacy of GreekBritish relations in effecting Greek liberation, as Ida and Osmyn relocate to Russia to plan Greece's liberation. However, as Owenson's ambivalence toward a Russian-Greek alliance at the end of Ida reveals, this is not entirely the case. She writes of Ida

Like the rest of the greeks [sic], sanguine and ardent in her hopes, and fearless in her views, for her country's good, she saw not that whatever ascendant Russia might have gained over the Turks, was now sacrificed to a premature effort in the cause of other powers. How far the entire restoration of the greek [sic] empire was compatible with its moral and natural state, was a point her feelings did not suffer her to consider, or the ardor of her imagination to decide on; but whatever change might extend itself to the promotion of the interest and happiness of every class of its subjects, by the equal preservation of their rights, the general participation of the political institutions, and the universal toleration to religious opinions. (4.287-88)

Here, Owenson invites her readers to consider Russia's (past) interventions in Ottoman affairs and to see what her heroine, "sanguine and ardent in her hopes" for Greek independence, cannot: that Russia has not necessarily ever been interested in helping Greeks become independent, and certainly not in reestablishing the classically-inspired Greece Ida and Osmyn strive to restore. Indeed, the little hope Russia had given Greeks by warring with the Ottomans "was now sacrificed to a premature effort in the cause of other powers"- that is to say, Russia has abandoned the Greek mission (by signing a series of treaties with the Ottomans in the late eighteenth century) and attempted to gain power elsewhere. Further, Owenson suggests that "the entire restoration of the greek [sic] empire"-of a Byzantine (Orthodox) Empire, a vision most 
Greeks supporting the Russians had - is incompatible with her heroine's desire to see a classical Modern Greek nation that embraces the (Rousseauian) values of equal rights and religious toleration.

By adding such an ambivalent passage to the last pages of her novel, Owenson compels her readers to question Ida's and Osmyn's partnership with the Russians and to consider that Russia might not be Greece's best hope for independence. By mentioning Ida's concern with "the promotion of the interest and happiness of every class of [Greece's] subjects," Owenson reminds her readers of Ida's diako's bicultural (English and Greek) experiences and the liberal education with which he provided his niece. Although we do not at the end of Ida witness a Greece-Britain political alliance, this does not mean that Owenson rules one out in the future, inconceivable as it was in 1809 when the novel was published. Owenson, I argue, is still by the end of her novel dedicated to a vision of a classical Modern Greek nation and a liberalized Europe, a future reality that depends on her commitments to Romantic nationalism and British Hellenism (thus the importance of her extensive analyses throughout the novel of British-Greek relations). Important too, though, is the point that Owenson does not merely envision the founding of a Modern Greek nation through Greek-European relations but also a more liberal (and even feminized) Europe as a result of European nations' increased knowledge of classical Greek institutions. The relationship between Greece and Europe was to be mutually beneficial.

\section{Greece-West Estrangement in Anastasius}

"In the way of literature, we have been all busied with Mr. Hope's Anastasius; or, Memoirs of a Greek, which certainly has a great deal of excellent matter in it; but, upon the whole, it is a heavy book, and one which bespeaks a most unhappy feeling in its author."

(Sydney Owenson) $^{11}$

\footnotetext{
${ }^{11}$ Sydney Owenson (Lady Morgan), Lady Morgan's Memoirs: Autobiography, Diaries and Correspondence, Ed. W. Hepworth Dixon, Vol. 1, London: William H. Allen \& Co, 1862, p. 134.
} 
'Byron spoke to-day in terms of high commendation of Hope's 'Anastasius;' said that he wept bitterly over many pages of it, and for two reasons,- - first that he had not written it, and secondly, that Hope had; for that it was necessary to like a man excessively to pardon his writing such a book - a book, as he said, excelling all recent productions, as much in wit and talent, as in true pathos. He added, that he would have given his two most approved poems to have been the author of "Anastasius.",

(Lady Blessington) ${ }^{12}$

\section{"I thought Anastasius excellent-did I not say so?" (Lord Byron) $^{13}$}

Immediately upon its release in December 1819, the anonymously-published Anastasius, about a young Greek man who travels throughout the Ottoman Empire in pursuit of rank and wealth, was a hit. Publisher John Murray was shocked by the success of the novel, telling printers Oliver and Boyd "I was not aware that Anastasius, from an unknown Author would have sold so well—it is nearly out of print" (Acc. 5000/189) after receiving a letter from them pressuring him to send more copies a mere few weeks after the first edition's release. "The second edition of Anastasius [of 1250 copies, published in early 1820]," writes John Rodenbeck, "sold out in 24 hours" (xi), with a third edition following later that year. ${ }^{14}$ Because the book was published anonymously, many readers mistakenly attributed authorship of the book to Lord Byron, popular for his poetry and verse romances about Greece and the Ottoman world. ${ }^{15}$ Only after Hope published a letter in

\footnotetext{
${ }^{12}$ Marguerite Gardiner (Lady Blessington), Lady Blessington's Conversations of Lord Byron, Ed. Ernest J. Lovell, Princeton: Princeton University Press, 1969, p. 51.

${ }^{13}$ Lord Byron, "Lord Byron to John Murray II, 28 Sept 1820," Byron's Letters and Journals, Ed. Leslie A. Marchand, Vol. 7, Cambridge, MA: Harvard University Press, 1978, p. 182.

${ }^{14}$ As per John Murray's ledgers, the first edition of 750 copies was published on 4 December 1819 and the second edition of 1250 copies was published in early 1820 (Murray Archives, Divide Ledger B 157); the third edition of 1250 copies was published in October 1820 (Murray Archives, Divide Ledger B 264).

${ }^{15}$ For example, Mary Russell wrote to Sir William Elford on 30 Jan 1820: "Did you, my dear friend, ever happen to read Mr Thomas Hope's book about furniture? [...] Well, this Mr Thomas Hope has, they say, written 'Anastasius.' The 'New Monthly Magazine' says so; but that's rather an argument against the fact, inasmuch as the 'New Monthly Magazine' does certainly, assertion for assertion, tell more lies than truths [...] it's a book which, but for this
} 
Blackwood's Edinburgh Magazine announcing that he wrote Anastasius was his authorship confirmed, though readers continued to speculate upon the novel's true writer. ${ }^{16}$ Hope, who had travelled to Greece in the late 1780 s and wanted to present what he termed a "strictly correct" (vi) historical representation of Ottoman Greece, constantly devalues classicized representations of Greece throughout Anastasius and dismisses the notion that Greeks desire Western foreign intervention in their country. In fact, as Hope writes in the same letter to Blackwood's confirming his authorship, his representation of Greece, based on his time in the East, has "avoided all antiquarian descriptions studiously, as inconsistent with the character assumed" (312). Rather, Anastasius portrays Greeks living, and in some cases even thriving, as members of a multiethnic Ottoman Empire.

In $I d a$, Owenson unites Britain and Greece in order to demonstrate how cross-cultural interactions can bolster European liberation movements, to encourage Britain to support a revitalized Modern Greek nation (in a classical form), and to dissuade her own nation from adopting an imperialist approach toward the Greeks. By creating a Greek heroine whose patriotism is dictated by her diako's bicultural Greek-British identity, who resists the Englishman Lord B's imperialist advances, and who speaks out about Greek national freedom while living in

testimony, I should from internal evidence have attributed at once to that prince of wickedness and poetry, Lord Byron. It's altogether Grecian; is not that like Lord Byron? It's exceedingly sceptical; is not that like Lord Byron? It complains of a jealous wife; is not that like Lord Byron? It is full of fine and gloomy poetry (in prose), which is of the very same style with Lord Byron's. It is still fuller of the light derisive mockery-the tossing about of all good feeling, so gibing and so Voltaire-ish, which no one could or would do but Lord Byron. [...] It is a most uncomfortable book - is not that like Lord Byron? If not written by him, it is certainly in his character; and a very powerful work it is for good and for evil—a sort of Eastern 'Gil Blas' — only bloodier, longer, less attractive. I shall remember it all my days; but I shall never think of reading it again" (2.84-85). See The Life of Mary Russell Mitford, Ed. A. G. L'Estrange, Vol.2, London: Bentley, 1870, pp.84-85.

${ }^{16}$ Although written prior to Hope's October 1821 Blackwood's letter, an Edinburgh Review article about Anastasius's authorship gives us insight into why so many readers could not believe Hope was the author: "Mr Hope will excuse us, - but we could not help exclaiming, in reading it, Is this Mr Thomas Hope?-Is this the man of chairs and tables - the gentleman of sphinxes - the Oedipus of coal-boxes - he who meditated on muffineers and planned pokers?-Where has he hidden all this eloquence and poetry up to this hour?" (93) Here, the Edinburgh Review makes reference to Thomas Hope's most popular publication before Anastasius: Household Furniture and Interior Decoration (1807), a book influenced by the neoclassical movement but which belied the author's knowledge of the Eastern world's social and political makeup. 
London, Owenson compels her readers to consider a closer (and mutually beneficial) relationship between Greece and Britain. As much as Owenson objected to British imperialism, she still believed the West provided Greece with the best opportunity for freedom from Ottoman rule. Hope's Anastasius, by way of contrast, questions Ida's construction of a classicized Modern Greek identity, commitment to Greek-West relations, and equation of Western intervention with Greek freedom.

Hope's assault on antiquarian conceptions of Modern Greece begins in the first pages of his novel with the introduction of Anastasius's father Sotiri, who criticizes Greeks purporting to be of noble pedigree:

In his own opinion he could boast of purer blood than any of the Palaeologi, the Cantacusenes, or the Comneni of the present day. "These mongrel descendants," he used to observe, "of Greeks, Venetians, and Genoese, had only picked up the fine names of former ages when the real owners dropped off: he wore his own;" and signor Sotiri saw no reason why he should not, when he went forth into public, toss his head, swing his jubbee like a pendulum from side to side, and shuffle along in his papooshes, with all the airs of quality. (1.1)

Although this passage is not specifically about Greeks identifying with their classical heritage, it does importantly scrutinize the ways Greeks (and others) exploitatively mediate their country's past. More than this, though, Sotiri's statement demonstrates that Greeks do not even think as far back as the classical past in tracing their roots; that is, Modern Greeks are not necessarily interested in identifying themselves with the pagan Ancient Greeks, preferring instead their Byzantine (and thus Orthodox) lineage (the Palaiologoi, Kantakouzenes, and Komnenoi families being the most affluent of the Byzantine imperial genera). The Modern Greeks are not the 
Greeks with which Europeans are familiar (i.e. the Ancient Greeks) and are much more ethnically, socially, and religiously complex than foreigners understand them to be, a point that is emphasized further by Sotiri's dress at the end of this passage. Hope orientalizes Anastasius's father by having him "swing" in his jubbee (a jubba is an ankle-length, robe-like garment) and "shuffle" in his papooshes (slippers), clothing typically worn by Eastern and Islamic peoples. By dressing like a Muslim, Sotiri can succeed in Ottoman Greece.

From the outset of the novel, Hope complicates European understandings of Modern Greeks by demonstrating that they neither are akin to, nor familiar with, their ancient predecessors, nor, as Owenson believes, desirous of being freed from the Ottomans with the help of Westerners. As Reşat Kasaba argues, “Anastasius is a record of its author's realization that the relations between the Greek communities and the Ottoman state were far more complex than [European] authors had initially imagined and that rescuing the Greeks from under the Ottoman rule and resurrecting their civilization was a formidable if not impossible task to achieve" (7). Indeed, Anastasius portrays Greeks living, and in some cases even thriving, as members of a multiethnic Ottoman Empire. In fact, so content is Sotiri with his position as a dragoman (an interpreter or translator) between Ottoman and European officials that when the Russians arrive in Greece, purportedly to help liberate the Greeks, he fights against them. Hope writes that, "[a]s a loyal subject of the Porte, and an old servant of the French government, he felt no sort of wish to be delivered from the yoke of the Turks" (1.2). By portraying Greeks like Sotiri, and thus resisting classicized incarnations of contemporary Greeks, Hope in turn establishes Greece as an unfamiliar territory that is not so easily "knowable" to English readers.

For Hope, the idea of sociocultural continuity between Ancient and contemporary Greeks is Enlightenment fiction, a point that plays out hilariously in Anastasius's discussion of his 
reading habits. Although Anastasius has grand ambitions (which we see him strive for throughout the course of the novel), his parents resolve initially to have him train to become a friar, a career that requires Anastasius to obtain "a smattering of learning" (1.9). Anastasius admits, though, that he "had a dislike to reading in the abstract" and that "even Homer, much as I liked fighting out of doors, found but an indifferent welcome in the study" (1.9). Anastasius's understanding of Homer is superficial, Hope implies, as the only lesson he takes from the bard, who illustrates the horrors of warfare, is a love of fighting. Anastasius further emphasizes his obliviousness to Ancient Greek literature when he states

[B]ut when away from my books, I affected a great admiration for Achilles; called him, in reference to Epirus the land of my ancestors, "my countryman," and regretted that I was not born two thousand years ago, for no other purpose but to be his Patroclus. In my fits of heroism, I swore to treat the Turks as he had done the Trojans, and for a time dreamt of nothing but putting to the sword the whole seraglio—dwarfs, eunuchs, and all. These dreams my parents highly admired but advised me not to disclose in common. "Just rancor," they said, "gathers strength by being repressed."-Upon this principle they cringed to the ground to every Moslemin they met. (1.9-10)

Anastasius admits that his reverence for ancient heroes is "affected" and that his desire for freedom is merely "fits of heroism," a display his parents ask him to suppress as the family benefits from Greece not being liberated. Anastasius feels no real connection to Greece's ancient past, nor does he have any true notion of national emancipation. As Ludmilla Kostova argues, "Anastasius dislikes reading even Homer and is not directly influenced by the Iliad . . His identification with Achilles is through later stories that he has been told about him. This indicates 
Anastasius's alienation from what should be his cultural legacy" (183). Anastasius is likely also oblivious to his reference to ancient pederasty when he wishes to be Achilles's Patroclus - that is, his fighting partner and, as many classical authors suggested, his lover.

In contrast to Owenson, who portrays a classicized Greece amenable to European alliance and who considers Greek-Western relations to be potentially beneficial for Greece, Hope represents an orientalized Greece that has very few affinities with European countries, as well as Greeks and Westerners who have very little regard for each other. Indeed, living in Constantinople (Istanbul) after he has left his home island of Chios, Anastasius notes that "the representatives of all the potentates of Christendom, from Petersburgh to Lisbon, and from Stockholm to Naples, are here penned up together in [a] single narrow street, where they have the advantage of living as far as possible from the Turks among whom they come to reside" (1.154). By living apart from the Turks (Ottomans) while visiting the Ottoman Empire, European diplomats reveal their complete lack of desire for cultural integration with Eastern peoples, including Ottoman subjects like the Greeks, and thus help to further substantiate Hope's questioning of writers like Owenson who saw in Europe potential freedom for Greece.

Anastasius too, though, shows very little concern for forging connections with Europeans. In fact, in order to advance his life's prospects, Anastasius does not consider journeying to Europe, but rather, decides to convert from Christianity to Islam and to adopt the name Selim. ${ }^{17}$ That is, Anastasius chooses to remain a subject of the Ottoman Empire, in a world

\footnotetext{
${ }^{17}$ While not common, religious conversion in the Ottoman Empire did occur. In “"After Being So Long Prisoners, They Will Not Return to Slavery in Russia': An Aegean Network of Violence between Empires and Identities" (The Journal of Ottoman Studies XLIV [2014]: 221-34), Will Smiley explains that some Greek captives converted to Islam in order to be released from prison, revealing that "the question of 'who was an Ottoman' was complex and contested, but was also a matter of life and death, and of freedom and captivity" (231). In "Christians in the Eighteenth-Century Ottoman Mashriq" (Eighteenth-Century Studies 47.2 [2014]: 177-94), Nabil Matar explains that "religious 'shifting' occurred in the Arab urban centers of the Ottoman polity" and that this shifting was a sign of "social mobility, openness, and an 'espace de jeu" (184). See also pages 150-51 of David Brewer, The Flame of
} 
with which he feels more familiar. A transition that begins with the young man's outward appearance—including an "ample beneesh of finest broadcloth" (1.42)—Anastasius's conversion to Islam is complete when he decides to become a Muslim in order to escape punishment for sleeping with an upper-class Turkish woman named Esmé. Pursued by Esmé's husband's troops into a mosque and seeing no means of escape, Anastasius concludes "[o]ne human measure only remained to save my life. I drew my dagger, threw my cloak over my face, leaned my back against the mihrab, and cried, 'I am a Moslemin!'” (1.183). Anastasius tells us that, following this declaration, "every breath of accusation was hushed, every hand became suspended. A magic power seemed to arrest the daggers on my very breast” (1.184).

Although readers might be skeptical about Anastasius's conversion, he insists it is sincere, that "[t]he seemingly bold measure had long been preparing in petto" (1.185). Hope's decision to have his protagonist become Muslim differentiates his portrayal of Modern Greeks from the Westernized construct of (classical) Greekness that we witness in Owenson's novel. Hope does not allow his readers such a familiar understanding of Modern Greek identity as does Owenson. This does not mean, however, that Hope completely dismisses Western influences on Greek identity. In fact, as Anastasius realizes gradually that becoming Muslim affects very minimally his social standing in the Ottoman world, he begins to seek other methods of constructing his identity—namely, he considers how becoming a European might contribute to a better livelihood. Anastasius's negotiation of Eastern and Western customs, ideas, and identities—even if he ultimately rejects his Western teachings—reveals the multiple forces that contributed to the making of Modern Greek national subjecthood in the early nineteenth century.

Freedom: The Greek War of Independence 1821-1833 (London: John Murray, 2001) for other examples of religious conversion amongst the Greeks. 


\section{Anastasius Negotiates His Greek Identity}

After repeatedly failing to attain rank or power in the Ottoman world as Selim (the novel follows the same basic formula: Anastasius rises to a position of minor power before being disgraced and forced to flee to another part of the empire and start all over again), Anastasius begins to reconsider a new path in life. Specifically, he starts to think less about himself as part of an Ottoman collective, and more about his individuality in ways that evoke European Enlightenment beliefs about "rights" and "freedom." While Owenson throughout Ida clearly indicates how Ida's Greek national character influences and is influenced by English culture and her transnational experiences, Hope's portrayal of Anastasius's Greek identity and how it changes as a result of his growing familiarity with Western ideas is both a subtle and slow process and, importantly, one that is meant to elicit laughter. That is, Hope seriously deliberates upon how Western Enlightenment concepts such as "liberty" and "rights" might impact Anastasius's sense of self, but also undercuts their applicability in Anastasius's life by having their proponents disappoint the young Greek. By mocking these Western concepts, in turn, Hope disrupts cultural divides between a "savage” East and an "enlightened” West, deflates Europe's belief in its superiority over Eastern countries and, importantly, deconstructs the equation between the West and a reformist emphasis on rights and freedom. As Hope demonstrates, proponents of Western ideas about liberty and rights are often merely concealing their own hypocrisy.

Anastasius becomes familiarized with Western ideas when he is reacquainted with his childhood friend Spiridon Mavrocordato, who becomes his moral and spiritual mentor. ${ }^{18}$ Spiridon, Anastasius tells us, comes from a Phanariot family of high standing and his father

\footnotetext{
${ }^{18}$ The Mavrocordatoses were a Phanariot family that had distinguished itself in the Ottoman Empire and whose members had become hospodars in Wallachia and Moldavia. Spiridon Mavrocordato, though, is a fictional name.
} 
"aimed at nothing less than seeing him some day Bey of Valachia or Moldavia, as several of his namesakes had been before him" (2.130-31). Spiridon's Phanariot background is a significant point for my discussion of Greek-Western interactions in Anastasius, as the Phanariots were Greeks from Constantinople who were largely educated in the West, and are credited with encouraging "the gradual development of an opposition to old dogmas, an educational emancipation, and an organization of new ideas in order to spread encyclopedic and scientific knowledge to Greeks" (Papachristou 84). The Phanariots had a reputation for travelling to Europe and bringing back to Greece the Western knowledge they had acquired abroad, David Brewer commenting that they "proved to be enlightened patrons of Greek culture and their courts became channels through which Western ideas penetrated the far-flung Orthodox commonwealth that existed, and to a degree flourished, under Ottoman rule" (21). In fact, Anastasius remarks that, though he could have used their help when he first arrived in Constantinople (in volume one), Spiridon and his father were "gone on business to Trieste or to Vienna" (2.130). And at the end of Anastasius, when Hope's protagonist attempts to reunite with his friend, he is told that Spiridon is travelling through Europe and is likely to be found "at Paris or in London" (3.285).

The Phanariots did not, however, only represent a connection between Greece and West, but also been East and West as they thrived in the Ottoman Empire by acting as intermediaries between Ottomans and Europeans. As Christine Philliou explains, "[P]hanariots were suppliers of necessary, strategic intelligence to an Ottoman state that was itself becoming increasingly enmeshed in intraimperial continental politics" (20). By diversifying in professions, regions, and ethnicities, Phanariots could attain such prestigious titles as woiwode (or voyvoda) or royal dragoman, positions that Philliou claims "were of near royal status" (22). Indeed, in Anastasius, the titular character's former employer Mavroyeni, an interpreter for Hasan Pasha who had in 
volume one hired Anastasius as an assistant, is in volume two promoted to Hospodar of Valachia (Wallachia), leaving Anastasius to wonder how he could do it "in the very teeth of every Ipsilandi, Morosi, Callimachi and Souzzo whom the Fanar could muster to oppose his intrusion?" (121).

Hope's addition of a subplot with the Phanariot Spiridon is significant, I suggest, as it is through his relationship with Spiridon that Anastasius learns about Western ideas and further negotiates his own Greekness. Spiridon's Westernized learning and Anastasius's Ottoman-Greek cultural mentality converge to create a hybridized space in which there is a possibility for the emergence of a new Greek identity, even if this is just at the personal level for Hope's protagonist rather than at the national level, as in Ida where Ida's bicultural education is directed toward an eventual revolution. In Hope's text, Spiridon (like Ida's diako) is a foreign-educated Greek scholar preoccupied with the spread of Enlightenment ideas (hence why he makes Anastasius his pupil). So dedicated is Spiridon to his learning that While with all his canvas spread to the breeze of the passing hour, the father sailed down the muddy tide of the Fanar, the son would retire to his closet, there to imbibe long draughts of wisdom at the pure spring of philosophy; and as, in a society where literary discourse is despised and prohibited, men do not peruse books merely to quote sentences, he found more leisure to ruminate upon his reading, and to digest his volumes. Hence his understanding rose far above the level of his age and country: for in those days modern Greece had not yet attained that miraculous emancipation from the bondage of error and superstition, so vauntingly set forth, I am told, by the $\mathrm{P}$-'s and the $\mathrm{K}$-'s of the present enlightened period; and in the more than Cimmerian darkness which surrounded 
him, Spiridon was almost the only person I could have named, with whom morality weighed more than dogma, and who attached greater importance to inward goodness than to outward practice. (2.137)

This passage, infused with Hope's sardonic humour, tells us a great deal about Spiridon's Modern Greek Enlightenment ideals and indicates how Anastasius might be influenced by his friend's ideas. Spiridon, we are told, studies philosophical works that he has the opportunity "to ruminate upon," as literary discourse is prohibited in Constantinople (although Hope's indication that Greeks "do not peruse books" is false, as I discuss in Chapter 2). Hope then links Spiridon's learning —albeit mockingly—-to the work of Greek Enlightenment writers "of the present enlightened period." These writers, who are referred to only by the first letter of their last names, are likely Daniel Philippidis and Grigorios Konstantas. Together, Philippidis and Konstantas published Modern Geography (1791), a text which criticized the church for spreading superstition and passivity amongst the Greeks, promoted French revolutionary ideas, encouraged Greeks to become familiar with Western ideas, and emphasized that Greece was geographically (and thus economically) ideally located at the crossroads of Europe, Asia, and Africa. ${ }^{19}$ Spiridon, a progenitor of Enlightenment Greeks like Philippidis and Konstantas, symbolizes the possibility of a Modern Greece free from the Ottoman Empire and associated more closely with Europe. And in an Ottoman world where Anastasius has learned that "dogma" and "outward practice" are essential to survival, Spiridon can potentially reveal for the protagonist a new path in life where "morality" and "inward goodness" becomes his objectives.

Anastasius, though, remains resistant to Spiridon's influence. He claims that his friend is "the person worst calculated" (2.142) to change his personhood and even conflates Spiridon with

\footnotetext{
${ }^{19}$ See Paschalis Kitromilides, "The Enlightenment in Southeast Europe: Introductory Considerations," Discourses of Collective Identity in Central and Southeast Europe (1770-1945) Vol 1, Ed. Balázs Trencsényi and Michal Kopeček, Budapest: Central European University Press, 2006, 45-56.
} 
the Ottoman officials who also wished to mentor him but who ultimately left him degraded. Despite his suspicions toward Spiridon's intentions, however, Anastasius is clearly affected by the Phanariot Greek's philosophies. In fact, he articulates his resistance to Spiridon by using language that, suspiciously, echoes that of such Enlightenment philosophers as Jean Jacques Rousseau and John Locke, both proponents of individual rights and freedoms. ${ }^{20} \mathrm{He}$ declares that he has a "natural aversion from the shackles of civilisation" (2.143) and that he believes Spiridon to be "a confederate in the great plot against my natural rights and liberties" (2.144). Later, Anastasius admits that Spiridon's teachings have influenced him—stating that the Phanariot holds an "empire over my will" (2.155) —and begins to recognize how fettered he truly is:

"Is it I—is it Anastasius," I exclaimed, "who suffers the silly and minute forms of society, like the small but numerous threads and meshes of a net, to confine every limb, and to impede every motion? Is it I who have lost all free agency, and like a puppet can only obey the pleasure of another?" And at these mortifying thoughts shamed burned my cheek, and anger sat quivering on my lips (2.157).

Anastasius's acquaintanceship with Spiridon forces Hope's protagonist to think about his selfhood differently and to desire a degree of autonomy he has thus far not been able to establish. Anastasius realizes as a result of his conversations with Spiridon that he is "“a twig torn from its stem, that strikes no root, and bears no blossom"” (2.177).

However, while Anastasius feels fettered and isolated by society and desires change, Spiridon's mentoring ultimately fails to change him because Hope's protagonist does not believe his friend's philosophies are applicable to the everyday realities of the Ottoman Empire. In particular, Anastasius takes issue with Spiridon's theory about the "social compact," most likely

\footnotetext{
${ }^{20}$ See Jean Jacques Rousseau, On the Social Contract, Trans. G. D. H. Cole, New York: Dover, 2003; and John Locke, Two Treaties of Government, London: Awnsham and John Churchill, 1698.
} 
a reference to Rousseau's 1762 publication Du Contrat Social ou Principes du Droit Politique, a text in which the French philosopher proposes that governments should have in mind the best interests of their citizens and that all individuals should have equal rights and freedoms. ${ }^{21}$ In a discussion that spans several pages, Anastasius asks Spiridon how each individual in society can be certain that his or her autonomy and property are safeguarded from others and tells him that there should be a penalty for restricting another's rights. Spiridon replies “"you have described the social compact — the source of every law, the cement of every state ... what more have you to do but henceforth to abide, while this empire subsists, by all its stipulations"” (2.188). Anastasius is appalled by Spiridon's comment, telling him "Am I alive ... and awake; and do I hear a Greek, and under the yoke of the Turks, talk of a social compact—of an agreement intended for mutual benefit, support and protection, as of a thing actually subsisting ... had I only discovered the faintest trace of any such agreement between Christianity and Islamism ... who would have been more proud than myself of remaining a Greek, of standing by my oppressed countrymen, and of maintaining the glorious struggle to the last drop of my blood!” (2.188)

Although Anastasius's and Spiridon's friendship does not end immediately after this episode, their discussion about the social compact effectively ends Spiridon's influence over his acquaintance. It is simple enough for the affluent and well-connected Spiridon to speak of a social compact (as he is all but guaranteed a role in the Ottoman Empire's administration), but for Anastasius, a Greek who has had to abandon his family and adopt a Muslim identity, such a compact cannot be anything but fictitious.

\footnotetext{
${ }^{21}$ Jean Jacques Rousseau, On the Social Contract, Trans. G. D. H. Cole, New York: Dover, 2003.
} 
While Owenson suggests that Greek national identity can be restructured through cultural synthesis, Hope rejects this premise on the grounds that Anastasius cannot possibly identify with the Enlightenment ideals about which Spiridon teaches him. For Hope, Western philosophies cannot have any real effect in Greece as these ideas are incompatible with Greeks' everyday experiences in the Ottoman Empire. However, the issue is not only the fact that Western ideas do not work in Eastern contexts, but that individuals promoting liberty by touting Western theories are usually doing so for their own personal benefit. Spiridon misinterprets Rousseau's philosophy by suggesting that subjects should learn to live contentedly within the structure of their respective societies and thus employs the philosopher to forward his own personal ambitions as a member of the Phanariot Greek elite who collude with the Ottoman government that perpetuates Anastasius's servitude. David Brewer comments: "As the nearest approximation to a Greek aristocracy ... the Phanariots largely identified their interests with the preservation of the integrity of the Empire" (21).

Nevertheless, while Hope questions the effectiveness of Western liberal values for Ottoman Greeks, he also indicates that Anastasius has learned about his own Greek identity by questioning and rejecting Spiridon's teachings. In fact, even though Spiridon introduces the "social contract" to Anastasius, it is the latter who better understands Rousseau's implications. The French philosopher, like Anastasius, argued against abusive governments who limited their citizens' rights—or in Anastasius's words “ “[t]hey cut our claws, they clip our wings, and then they cry out with a smile of derision: poor pinioned eagle, fly if thou list!"'” (2.190). In his rebuttal to Spiridon, Anastasius reveals that his Greek national identity (as fractured a sense of it as he might have) is stronger than his friend's, as he expresses some degree of nationalist sentiment when he considers his "oppressed countrymen" and "maintaining the glorious 
struggle" with them. As Kostova argues, "[t]he protagonist's speech prefigures some of the arguments of later Balkan revolutionaries who similarly found Ottoman rule incompatible with European ideas of civil government. Besides, like the nationalists of the future, Anastasius is exasperated by the passivity and submission of the Greeks in the face of oppression" (187). By having Anastasius mimic arguments made by Western Enlightenment-inspired Balkan revolutionaries (the most popular of whom was Rigas Velestinlis, who published influential works concerning Greek freedom and national rights), Hope reveals how his protagonist's time with Spiridon (as the Muslim Selim) contributes to his ever-changing Greek identity. Spiridon forces Anastasius to consider, at the very least, his lack of personal rights and liberties-even while the author simultaneously indicates that Enlightenment ideas are incompatible with the realities of the Ottoman world.

Later in novel, when Anastasius is in Smyrna (Izmir), he receives yet another lesson about the falsity of Europe's potential to transform Greece from an Italian travelling poet named Cirico. Cirico tells Anastasius that "“[e]very where the young shoots of reason and liberty, starting from between the rents and crevices of the worn-out fabrics of feudalism, are becoming too vigorous any longer to be checked: they soon will burst asunder the baseless edifices of selfinterest and prejudice, which have so long impeded their growth"” (3.98). According to Cirico, everything from religious inquisition, to hereditary rights, to empty titles will be abolished, a process that has already begun, he informs Anastasius, in France (in the novel's timeline, the French Revolution is currently in progress). He counsels Anastasius to leave the Ottoman Empire for France and to seek assistance for Greece from the French: "“All that you have to do,"” explains Cirico, "is to present yourself in the august assembly of the great nation, as the representative of oppressed and mourning Greece"' (3.100). However, Hope once again, as he 
does repeatedly in the novel, diffuses the seriousness of revolutionary rhetoric by having Cirico, following this rousing speech, unexpectedly leave Smyrna with "his bill unpaid" and "his landlord's silver spoons" (3.100). Advocates for such concepts as liberty and rights, Hope suggests in the spirit of British anti-Jacobin novels, are those most likely to deceive others. As a result of Cirico's actions, Anastasius abandons his (half-hearted) plans to travel to Paris and instead goes to Baghdad where he becomes a member of the Wahabee movement (a religious sect with which contemporary ISIS is aligned). So unconvincing are the Western world's Enlightenment ideas that Anastasius is driven to the opposite political extreme.

In Anastasius Hope's protagonist constantly negotiates his identity (or perhaps, more accurately, multiple identities) through his experiences of East and his learning about the West. At times, Anastasius is drawn to the West, though for the majority of the novel's three volumes, he resists journeying to Europe. This changes, however, when near the end of the novel Anastasius reconsiders moving to the West (Trieste) for his son Alexis's education, forcing him to consider the ramifications of becoming a European and the differences between the East and the West. In particular, Anastasius conceptualizes his move as yet another conversion, one in which he will have to become familiar with the habits and manners of a people about whom he knows very little. "But what was the difficulty of changing the outward trappings of the body, to that of dismissing the habits rooted in the inmost recesses of the mind?" (3.351) ponders Anastasius to himself immediately after he begins his transition from Easterner to Westerner by changing his name back to his "truly Christian name of Anastasius, given me by my parents" (3.350) and by altering his outward appearance (he changes his garb and shaves). This thought, in turn, spurs an extended meditation on the differences between the East and the West. "In the East," thinks Anastasius, "each different age, and nation, and rank, and profession, however 
closely intermixed with the others, still retains its peculiar garb and formulas, its stated place and boundaries, as distinctly marked as they are immutably fixed" (3.351). As a result of the East's fixity, "it is easy to learn by rote the unchangeable exigencies of society" (3.351). In the West, by contrast, "each different sex, age, nation, rank, and profession, instead of the strongly marked eastern distinctness of outlines, on all sides only showed blending shades, evanescent forms, prominences rubbed away, and features confounded" (3.352). Anastasius had in fact learned this lesson earlier in the novel, when he had met an English traveller in Constantinople who spoke to him as if he were a lord though he was merely a "button-maker" (1.158). Further, according to Anastasius, the Western world is one in which life is constantly in flux, so much so that the human mind is "not even allowed to unbend in repose after business was ended; but must still, in the hours of leisure - not hours of relaxation - encounter the new toil of constantly supplying matter for discourse" (3.352-53). Anastasius believes himself ill-suited to live on a continent where he must always be adapting to change, and especially "at an age too when the cast of my own character was stiffened into irremediable permanence by the cold hand of time" (3.353).

Anastasius's distinction between a fixed East and ever-changing West, though certainly open to debate, ironically reveals how the East has prepared him for life in the West. Although Anastasius claims he will find it difficult to acclimatize to Western life, his entire journey throughout the East has seen him adapt to and adopt a multitude of identities (from Constantinopolitan dragoman, to Egyptian kashif [military leader], to Smyrnian merchant). In fact, of his journey through Egypt earlier in the novel, Anastasius states "frequently during my march, I assumed some disguise. Sometimes it was that of a travelling Syrian, sometimes of a Barbaresque, and sometimes of an Arab, enveloped in his abbah" (2.67). Anastasius has throughout his life enacted various identities which, according to his East/West formulation, 
actually make him better suited to Western life. As Peter Nicholls writes, "Anastasius, the hardhearted picaresque adventurer, becomes the very type of modern, Western man. The disguises and shifting identities that define him ... are wholly appropriate to what he calls 'the system of the West' (Vol. II, p. 372)" (58). Although the novel ends with Alexis dying upon arrival to Trieste and Anastasius retiring to Austria to die shortly thereafter (and therefore, with very little examination of Anastasius's time in the West), the protagonist's digression on the East and the West demonstrates that the Eastern world has prepared him for life in Europe and, more importantly, that there is perhaps very little difference between East and West when it comes to being a Greek caught in the middle.

\section{Hybridized Greece}

Ida and Anastasius consciously draw from (and reject) different Western discourses_-including travel writing, Enlightenment philosophy, and Neoclassicism - in producing portrayals of Greek characters meant to familiarize readers with Ottoman Greece and its modern inhabitants. Their depictions of Greece place the country and its people into a dialectical relationship with Europe, one which encourages British readers to rethink their ideas about Greece and the East. Both Owenson and Hope create protagonists who allow them to consider how Greeks' engagement with Western peoples and ideas might contribute to the conceptualization and establishment of new geographical vistas and national identities. Importantly, though, Owenson and Hope differ in their constructions of Greek national identity and their belief in the future possibilities for Greeks engendered by Greek-West intercultural relations. In Ida, Owenson supports fully Ida's bicultural education and its contribution to her Hellenic identity and patriotism, even if England itself (for the time being) ultimately fails her heroine. For Owenson, English education, significantly, contributes to the classicization of the Modern Greeks, which in turn makes them 
patriots better prepared to fight for their country. And even if Greek-British relations do not lead England to support Greece in revolution, Owenson is able to encourage her readers to envision a revitalized (and classicized) Modern Greek nation and to promote a more beneficial relationship between Greece and Britain.

Hope, on the other hand, resists having his protagonist conceptualize his identity through European models, though as I have suggested, Anastasius does come to understand better his "Greek self" precisely through his rebuffs of such characters as Spiridon and Cirico. In many ways, Anastasius represents a typical Modern Greek, as most were in the early nineteenth century not overly familiar with their country's classical past. As Yannis Hamilakis argues The rediscovery of the Hellenic heritage by the people of Greece was . . . a consequence of a number of processes linked to economic and political developments, as well as to ideological trends such as the glorification of Hellenic classical antiquity (which largely replaced Roman antiquity) by the European middle classes. The establishment of classical antiquity as the symbolic capital for the new nation was therefore a result of the adoption of a western ideal, that of Hellenism. (77)

Anastasius, I have argued, represents Hope's attempt to depoliticize uses of the Hellenic past and to reject linear and essentialist narratives of Greek identity that would have Ancient and Modern Greeks regarded as one people, as in Ida.

However, although Hope's portrayal of Anastasius encourages readers to think about Modern Greeks apart from the classical past, his novel does not focus extensively on vernacular (or Romaic) Modern Greek identity and culture (which was, as the nineteenth century progressed, viewed as a counterculture to Hellenism) and importantly, does not examine how 
Romaic identity could help Modern Greeks make autonomous claims for national independence. For an examination of British writers' engagement with Romaic culture as evidence of Modern Greeks' desire and ability for freedom, I now turn to Lord Byron's discussion of Modern Greek language, literature, and print culture and defense of Romaic Greek in Childe Harold's Pilgrimage, a work published during a period wherein a Hellenic model of Greece was becoming increasingly popularized throughout Europe. 


\section{Chapter Two}

\section{"Let Us Look At Them As They Are": Lord Byron and Modern Greek Language, Literature, and Print Culture}

"My researches, such as they were, when in the East, were more diverted to the language \& the inhabitants than to Antiquities."

(Lord Byron) ${ }^{1}$

\section{Introduction}

On 15 July 1811, Lord Byron, having returned to England after his travels in the Levant, wrote to his friend and travel companion John Cam Hobhouse to inform him of the items he had brought back from Greece. For Hobhouse, he brought back marbles and a painting of Athens. For himself, Byron procured texts, including, he told Hobhouse, "a Romaic Lexicon in three Q[uart]o vols, two or three Greek plays ... Meletius's Geography (we stole it from the Bishop of Chrysso), a Greek Grammar or two ...\& \& some other Romaic publications (and a manuscript or two which you shall publish as they are very curious if you like)" (Byron's Letters and Journals [hereafter $B L J 60)$. As he details these texts, Byron also mentions that he has transported "two live Greeks" (BLJ 60) who are to become his servants in England (he lists them after the "Greek Grammar or two" and before the "some other Romaic publications").

On the one hand, Byron's conflation of Greek people and Greek texts can be seen as a crude objectification of an entire ethnicity. It was not uncommon practice, after all, for British travellers to dismiss the modern inhabitants of Greece altogether and to focus instead on the ancient past, including classical Greek literature, politics, arts, and landscape. However, in Byron's case, I think it is more accurate to suggest that the poet's coupling of Greek people and texts demonstrates how invested Byron was in Modern Greek print as a medium through which

\footnotetext{
${ }^{1}$ George Gordon (Lord Byron), Byron's Letters and Journals: Famous in my Time, Ed. Leslie Marchand, Vol. 2, Cambridge, MA: Harvard UP, 1977, p. 134.
} 
to understand Modern Greece and its inhabitants; in this way, then, the texts he collected in

Greece were to him just as valuable as actual people. Indeed, Byron even treats them as

people,- - he tells Hobhouse in a letter dated 14 October 1811 that he is nervous about sending

Meletius's Geography to him because "he is so well bound, \& if we lose him!!" (BLJ 114) — thus

metamorphosing texts into a vision of sociability. From 1811 to 1814 , Byron wrote to various

correspondents explaining that the British could become better acquainted with Modern Greeks

through knowledge of their Romaic (vernacular) literature and language and made it his mission

to translate and publish Romaic literature in English. ${ }^{2}$ It is an interesting fact, and one which

further illuminates Byron's linking of Greek people and texts in his July letter to Hobhouse, that

Demetrius, one of the "live Greeks" Byron mentions, was an important contributor to the poet's

project to make Romaic literature more accessible to his British readership: he served as a Greek

and Albanian translator for both Byron and Hobhouse.

Byron first became interested in Modern Greek print culture when he was travelling throughout Greece from 1809 to 1811. In his "Note III" and "Appendix," two prose pieces which were published as part of Childe Harold's Pilgrimage, Byron provides his readership with a detailed, and immensely positive, account of Modern Greek print culture and Romaic literature and language. ${ }^{3}$ Importantly, Byron's "Note III" and "Appendix" came at a time when Modern

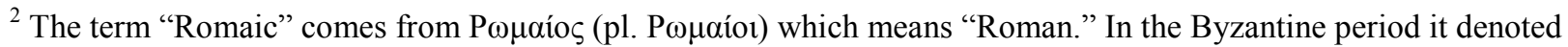
the inhabitants of the Eastern Roman Empire (hence P $\omega \mu \alpha$ ío $\zeta$ is the equivalent of today's 'E $\lambda \lambda \eta v$ [Greek]). After the Ottoman conquest of Constantinople in 1453, this name for the Greeks (and Greek millet) was preserved as part of

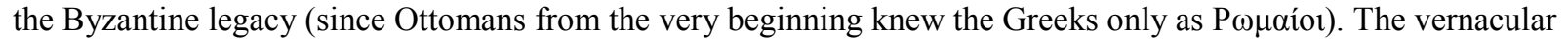

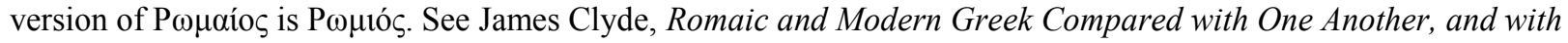

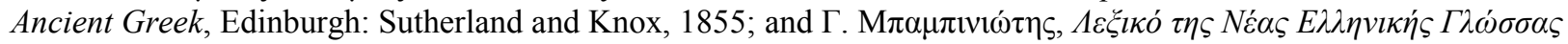
(G. Babiniotis, Dictionary of Modern Greek Language), Athens: Lexicology Centre, 2008. See also pages 2033-64 of G. Babiniotis's Dictionary of Modern Greek Language for a fascinating overview of Greek language books and dictionaries produced from the 16th century onwards.

${ }^{3}$ Although Byron does not indicate in his Contents for the first edition that the "Appendix" (which contains the works "Romaic Books and Authors" and "Specimens of the Romaic" and a "Fac Simile of a Romaic Letter") is connected to "Note III" (which is found in "Notes to Canto II"), he makes this point clear when he writes in "Note III" that "The reader will find a fac simile of the handwriting of a good scribe, with specimens of the Romaic, in an
} 
Greek language and literature were gaining cultural and social capital. As Peter Mackridge relates, Modern Greek had by the late eighteenth century (a time commonly known as "the Greek Enlightenment") obtained a level of prestige as it became "the language of commerce, education,

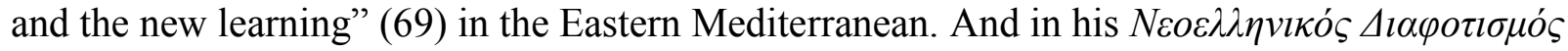
(The Hellenic Enlightenment) K. Th. Dimaras suggests that print became an important tool for enlightening Greeks both within and outside the boundaries of Ottoman Greece (29) and notes that a greater number of books (and not only those of a religious nature, the most popular book type) were being published as the eighteenth century progressed (30). Greece's new secular literary culture, it is commonly accepted, was prompted by affluent Greek families (known as the Phanariots) living in the Phanar region of Istanbul (Constantinople) who studied mainly French Enlightenment texts. As Kiriakoula Solomou writes, "the influence of Phanariot culture spread westwards from Constantinople and encouraged intellectual life in other parts of Greece although, as in Yanina, some of the aspects of Phanariot culture might be considerably modified" (143). Byron himself singles out the Phanar and Yanina (in Epirus) as areas where "the best Greek is spoken" ("Note III" 190; 2nd ed.), one of many comments that indicate he was aware of the various developments in Greek print and literature that had occurred before his first visit to Greece. $^{4}$

Despite much evidence that points towards Byron's keen understanding of advances in Greek literature, as well as his desire to learn more about Greek people's language and culture, the poet's engagement with Modern Greek literature and language remains a largely neglected

appendix at the end of the volume" (192; 2nd ed.). In this chapter, I will treat "Note III" and the "Appendix" as two separate works.

${ }^{4}$ If we consider that the Phanar and Yanina (or Ioannina) are both outside the periphery of Attic Greece, of which Ancient Athens was the centre, Byron's comment here reads as a move away from classical conceptions of Greece. In fact, in "Note I" of "Notes to Canto II," the poet writes the following: "“Athens', says a celebrated topographer, 'is still the most polished city of Greece.' Perhaps it may of Greece, but not of the Greeks; for Joannina in Epirus is universally allowed, amongst themselves, to be superior in the wealth, refinement, learning, and dialect of its inhabitants. The Athenians are remarkable for their cunning" (167; 2nd ed.). 
aspect of the poet's work. When discussing Byron's engagement with Modern Greece, critics

most typically examine his fascination with the Greek landscape and how his view of the modern country was distinct from that of his contemporaries; ${ }^{5}$ read the poet's journals and letters as his assessment of Modern Greece and the character of its inhabitants; ${ }^{6}$ and attempt to understand Byron's reasons for travelling to Greece to assist the Greeks in their War of Independence in the last years of his life. ${ }^{7}$ When scholarship does turn to Byron's writings about Modern Greek culture, it more often than not focuses on the poet's discussion of cultures that he sensationalized and popularized through his poetry, such as Klepht (brigand) society in The Giaour. ${ }^{8}$

In this chapter, I explore Byron's discussion of Modern Greek literature and language in "Note III" and the "Appendix" and, specifically, how these works acted as a response to an Edinburgh Review article which begins as a fairly even-handed analysis of Modern Greek literature and language before turning into a disparagement of Greek literature in general and the Romaic Greek language in particular. In the Edinburgh Review article, the anonymous reviewer briefly focuses on the political potential of Modern Greek literature before going on to subordinate Modern Greece to Ancient Greece, in effect reproducing the biases of the majority

\footnotetext{
${ }^{5}$ See Jerome McGann, Fiery Dust: Byron's Poetic Development, Chicago: University of Chicago Press, 1968; and David Roessel, In Byron's Shadow: Modern Greece in the English \& American Imagination, Oxford: Oxford University Press, 2002.

${ }^{6}$ See Leslie A. Marchand, Byron's Letters and Journals, Volume 2, Cambridge, MA: Harvard UP, 1977; and Peter Cochran, "Songs and Stanzas, Stanzas and Songs: Greece in Childe Harold and Greece in Don Juan," Byron's Poetry, Ed. Peter Cochran, Newcastle upon Tyne, England: Cambridge Scholars, 2012, pp. 171-77.

${ }^{7}$ To this day, William St. Clair's That Greece Might Still Be Free: The Philhellenes in the War of Independence (Oxford: Oxford UP, 1972) remains an influential work in the field. In his seminal book, St. Clair discusses Byron's decision to join Greece's fight for independence and how his decision to do so incited philhellenes throughout Europe to also commit themselves to Greek freedom by fighting for Greece. Leslie Marchand's Byron: A Biography (New York: Knopf, 1970) too provides an intriguing account of Byron's time in revolutionary Greece. Two of the most current, and best, scholars to write about Byron's commitment to Greece and its independence from 1821-24 are Stephen Minta and Roderick Beaton. See Stephen Minta, On a Voiceless Shore: Byron in Greece, New York: Henry Holt, 1998; Stephen Minta, "Lord Byron and Mavrokordatos," Romanticism 12.2 (2006):126-42; and Roderick Beaton, Byron's War: Romantic Rebellion, Greek Revolution, Cambridge: Cambridge University Press, 2013.

${ }^{8}$ See Daniel P. Watkins, Social Relations in Byron's Eastern Tales, Madison, NJ: Fairleigh Dickinson University Press, 1987; and Barbara Ravelhofer, "Oral Poetry and the Printing Press in Byron's The Giaour (1813)," Romanticism 11.1 (2005): 23-40.
} 
of his contemporaries. Byron's response, in turn, urges readers to move away from the kind of analyses of Greece that the Edinburgh Review performs (i.e. its preoccupation with Ancient Greece; its prioritization of Modern Greek politics over literature) and instead to take note of the ways in which Modern Greek culture was developing and thriving as evidenced by the country's literature.

In his article "Byron and the Eastern Mediterranean: Childe Harold II and the "polemic of Ottoman Greece,”” Nigel Leask writes: “In a way Byron's defence of modern Greek language and literature foreshadows the later debate in independent Greece between the partisans of katharevousa (classical purists) and dimotiki (supporters of the vernacular as it was spoken)" (100). Leask is right to note that Byron inserted himself into the debate between classical purists and vernacularists with his "Notes" and "Appendix." However, it may be more accurate to say that Byron in his "Notes" and "Appendix," rather than foreshadows, directly engages with contemporary language debates taking place while he was in Greece between 1809-11 (debates which were in fact precursors to the later major one between supporters of katharevousa and dimotiki). ${ }^{9}$ Byron's defence of Romaic Greek literature and language in "Note III" and the "Appendix" indicates that he had in the early part of his career decided to take the side of the vernacularists, a position that is particularly significant as it differed markedly from the predominant philhellenic discourse of the early nineteenth century—namely, that of a "Hellenic" Modern Greece.

The idea of a Modern Greece that would be established by harkening back to the Hellenic past gained currency in the late eighteenth and early nineteenth centuries as Europeans learned more about Ancient Greece and Modern Greeks, as Greeks became better informed about

\footnotetext{
${ }^{9}$ Peter Mackridge examines this debate in Chapter 1 of his Language and National Identity in Greece, 1766-1976 (Oxford: Oxford University Press, 2009).
} 
European nationalism and Ancient Greece by reading European scholarship, and, perhaps most importantly, when Greece made its bid for independence in 1821. Roderick Beaton explains that before, during, and after the war, Greece had to "create its own past, that is, to select and endorse those elements of earlier Greek history which retrospectively could claim to have made the present existence and future aspirations of the nation inevitable" ("Romanticism in Greece" 99). Artemis Leontis adds that one of the goals of Greek leaders during and after the war was to convince Greeks and foreigners that "[ $[$ ] he territory of Hellas could exist for rebelling Greekspeaking Ottoman subjects as the sacred land of historical restitution, if only Greeks would inform themselves of their glorious ancestry" (19). By the 1830s, a Hellenic Modern Greece was regarded, both in Greece and the rest of Europe (but not without detractors), as the only viable model for defining the newly-established state's national identity.

In this chapter, I am not suggesting that either "Note III" or the "Appendix" constitutes a fully articulated manifesto about Modern Greek nationhood or the Modern Greeks—Byron's mind was very much not made up about either of these topics. ${ }^{10}$ Rather, I am proposing that his approach to writing about Modern Greece in these works acts as an explicit rejection of the classicizing impulse shared by many European writers including, as we shall see, the critic for the Edinburgh Review to whom the poet responds. This position, of course, does not discredit the work of many scholars - amongst them Jerome McGann, William St. Clair, and Leslie Marchand — who emphasize that Byron's philhellenism grew out of his appreciation for Ancient Greece. ${ }^{11}$ Rather, I suggest that by examining Byron's response to the Edinburgh Review and, in

\footnotetext{
${ }^{10}$ Peter Cochran even goes so far as to suggest that Byron cared very little for the Modern Greeks or their freedom. Peter Cochran, "Songs and Stanzas, Stanzas and Songs: Greece in Childe Harold and Greece in Don Juan." For a counterbalance to Cochran's views, see Stephen Minta, On a Voiceless Shore: Byron in Greece and Roderick Beaton, Byron's War: Romantic Rebellion, Greek Revolution.

${ }^{11}$ See Chapter 2 of Jerome McGann's Fiery Dust: Byron's Poetic Development (Chicago: University of Chicago Press, 1968), especially pages 31-111; and Chapters 7 and 8 of Leslie Marchand's Byron: A Portrait. William St.
} 
particular, his defense of vernacular Greek, we can recognize more clearly the poet's nuanced understanding of the differences between Ancient and Modern Greece. Simply put, Byron was a philhellene who admired Greece's classical past, but one who also wanted to move away from a representation of contemporary Greece that depended upon recourse to the past and dubious comparisons between Ancient and Modern Greeks.

Past studies, from Jerome McGann's Fiery Dust to Louis Crompton's Byron and Greek Love, which have recognized that Byron's early travels throughout Greece helped the young poet deal with personal issues—including the deaths of his loved ones and his bisexuality—have helped to highlight that Byron had a deep attachment not only to Ancient, but also Modern Greece. In my chapter, I emphasize the intercultural relationship Byron sought to establish between the British and the Greeks in his writing and argue that his assessment of Modern Greek literature and language illustrates that the poet's relationship with Greece was, rather than purely introspective (as Romantic Hellenism has so often been framed), at least equally extrospectiveByron was profoundly committed to learning about another culture. Further to this, and despite the Saidian impulse to regard Western interactions with the "other" suspiciously, I contend that Byron's attachment to Greece (a country considered to be both East and West), while certainly ideologically, politically, and socially conditioned, did not involve a desire to "dominate" the country. ${ }^{12}$ Rather, I see in "Note III" and the "Appendix" an attempt for Byron to move away

\footnotetext{
Clair mentions Byron's admiration for classical Greece in That Greece Might Be Free, but focuses more so on the poet's pragmatism in deciding to join the Greek War of Independence. See Chapters 16 to 19.

${ }^{12}$ The crux of Said's well known and cited argument in Orientalism (London: Penguin, 1978) is that the West's interactions and descriptions of the East involve a desire to control it: with knowledge of the East comes the power to subjugate it. While I recognize that a young, classically-educated British aristocrat might feel himself to be in a position to speak for the Greeks, and am mindful of Gillian Rose's suggestion that "the politics of claiming to be an insider are also often the politics of claiming power" ("Place and Identity: A Sense of Place" 116), I do not see Byron's involvement with Greece as being driven by this desire. Instead, my chapter takes a cue from Manfred Pfister's and Maria Schoina's studies of Romantic-era writers' travels in Italy. In the Introduction to The Fatal Gift of Beauty: The Italies of British Travellers (Amsterdam: Rodopi, 1996, pp.1-22), Pfister uses the term Meridionism to designate relationships between two European countries and suggests that "even if this intra-European
} 
from predominantly classical conceptions of Greece and to introduce his British readers to a modern people with whom they were very little acquainted. As he writes in "Note II" to Childe Harold's Pilgrimage II: "[I]nstead of considering what they have been, and speculating on what they may be, let us look at them as they are" $(174 ; 2$ nd ed.).

\section{The Edinburgh Review and Modern Greek Print, Literature, and Language}

Byron was intensely aware of how detrimental comparisons between the Ancient and Modern

Greeks were bound to be - the Modern Greeks were always doomed to be regarded as second rate in comparison to their forebears. This kind of condescending attitude toward Modern Greeks, and specifically their literature and language, is exhibited in the April 1810 edition of the Edinburgh Review. In this volume, an anonymous critic - whom Byron later believed to be Edward Valentine Blomfield (Marchand, Note 1 102)—provides a review of Adamantios Korais's Geographie de Strabon, a French translation of the Ancient Greek geographer Strabo's work. Korais (or Coray) was by the time of this review one of the best-known Greek writers in European literary circles, having gained a reputation for himself as a great scholar in Paris, where he lived from 1788 until his death in 1833 (Mackridge 102). Indeed, the Edinburgh Review writer begins his review by acknowledging the fact that the journal's "attention was first directed to this publication, by the celebrity of the reputed translator" (55).

Before he offers his assessment of Korais's translated work, however, the Edinburgh Review critic first provides his readers with a brief overview of recent developments in Modern

\footnotetext{
Meridionism has not had the same far-reaching and devastating political consequences that Orientalism brought ... it has played an incisive role in the formation of British and European self-understanding, in cultural representations, practices and politics" (3). More recently Schoina in Romantic 'Anglo-Italians': Configurations of Identity in Byron, the Shelleys, and the Pisan Circle (Surrey: Ashgate, 2009) has emphasized that early nineteenth-century ItalianBritish relations are "marked by mutual vulnerability, as the cultural identities of both the 'coloniser' and the 'colonised' are influenced in this encounter. More significantly, as the circulation of power involved in the exchange of authority perpetually reverses and undermines the two positions, the reversibility of 'self' and 'other' comes as a result of the constant negotiation between opposite forces and impulses" (22).
} 
Greek literature. According to the reviewer, "[t]he state of literature in modern Greece, is a very interesting subject; and we have to regret that the works, which contain the principal information on the subject, are both few in number, and difficult to be met with" (56). Despite the writer's claim that Modern Greek literary sources are scarce and that these few works are largely unavailable to readers outside of Greece, the article does mention that Greeks are eager to become educated. Proof of this thirst for knowledge can be seen, the reviewer suggests, by noting that the Greeks have begun to pursue studies at universities throughout Europe and to establish printing presses in Trieste and Vienna "for the purpose of multiplying books in Romaic Greek" (57). The reviewer purports that, because Greeks in Trieste and Vienna have put forth an effort to proliferate Modern Greek texts, it is in these two cities and in Venice (another Greek intellectual hub) that "the most intelligent of the modern Greeks are to be met with" (57).

In his article, the writer for the Edinburgh Review, perhaps expectedly, frames his discussion of Modern Greek literature in the context of contemporary Greek politics, as did many early nineteenth-century British writers, including, as I will show, Byron. The reviewer is interested in examining what the production and diffusion of literature amongst the Greeks can tell readers about their national character and whether, importantly, the Modern Greeks can become educated and civilized enough to earn their freedom from the Ottoman Empire. In short, the Edinburgh Review critic wants to determine whether literary production can affect any real political and social change for the Greeks.

Although the reviewer is sympathetic toward the plight of the Greeks, he is nevertheless not convinced that the current state of their literature signals a significant change for the people. "While circumstances remain as they are," he writes, "we doubt whether the meritorious efforts of Coray, and a few of his enlightened countrymen, will be able to counteract in any considerable 
degree, the intellectual torpidity which their political condition naturally occasions" (57). The reviewer's strong if implicit assumption about the connection between knowledge and freedom and the necessity for a country to first obtain its liberty before becoming an educated nation ignores the intellectual advancements the Greeks had made in the late eighteenth and early nineteenth centuries, of which Byron was made aware during his time in Greece. By suggesting that Korais and his fellow writers - Greeks living outside of Greece, we should be reminded — do very little to help their fellow countrymen overcome their "intellectual torpidity," the reviewer effectively neutralizes the political function of Modern Greek literature, or indeed any other value it may have had.

In fact, after adducing that there can be no intellectual culture without national freedom, the writer's focus shifts from a consideration of Modern Greek literature with respect to Greece's political condition, to a discussion of Romaic in relation to classical scholarship. This shift, as I will soon discuss, becomes Byron's main contention with the Edinburgh Review piece. If Modern Greek literature cannot help change the political and social climate of Greece, the modern language, argues the Edinburgh Review writer, can still be of value to scholars studying Ancient Greek:

The advantages of an acquaintance with the modern Greeks, are perhaps more extensive than is generally imagined. They are not confined to the traveller or foreign merchant; but may prove a powerful auxiliary to the classical scholar. To those who have occasion to consult Greek manuscripts, it will furnish the means of frequently detecting their age, the original from which they were copied, and their various possessors; — of all which particulars, some notices are usually prefixed in the Vulgar 
Greek. Many scarce and curious words, too, retain their primitive signification in the present corrupt state of the language; and many valuable words can never be properly understood without a knowledge of the modern idioms. (59)

In abrupt fashion, then, the Edinburgh Review critic has in the course of a couple of pages gone from examining the nature of early nineteenth-century Greek literature and its potential for liberating the Greeks, to determining that Modern Greek is only valuable insofar as it can help scholars better understand Ancient Greek, a language that is, according to the reviewer, "in its pure state" (59). As Byron demonstrates in his rebuttal to the Edinburgh Review, the critic's proposal that classical Greek is superior to Romaic is a product of his limited understanding of advancements in everyday Modern Greek cultural life generally, and in Romaic literature specifically.

If the Edinburgh Review writer's judgment of Romaic as a "corrupt" language seems sudden considering his attempt to understand genuinely Modern Greek literature only a few pages earlier, so too does his assessment of Modern Greek writers, like Korais, who translate Ancient Greek works: "[I]t may perhaps be thought, that no persons are so likely to understand the writers of ancient Greece as the scholars of modern Greece ... Yet we are inclined to think, that the very reverse of this is the case; and that the circumstance of the vulgar Greek being his native tongue, so far from abiding him in his pursuits, must rather prove an embarrassment" (59). The portrait of the Modern Greeks that emerges by the end of the Edinburgh Review's survey of Modern Greek literature is one of a people who, in the main, have been left intellectually torpid as a result of their enslavement by the Ottoman Empire. Even someone as influential and respected as Korais does not escape the review unscathed. The Modern Greek language-which 
by the early nineteenth century had evolved to include loan words from European and Middle Eastern languages - too is dismissed as "a motley assemblage of Greek, Latin, Turkish, French, and Italian words" (58). ${ }^{13}$ The reviewer's opinion of the vernacular very clearly aligns him with language purists who sought to purge Modern Greek of any foreign elements and believed that the Romaic language reflected Greek subservience. In fact, he explicitly identifies a purified Greek language with national freedom: "Much, it seems, has been done in pursuance of a plan, which we believe was struck out by Potemkin, towards purifying the modern Greek; and we have no doubt, but that, if political obstacles were removed, in the course of a few years the language of the country would approach very nearly to the purity of that spoken in the court of the successors of Constantine" (57-58). ${ }^{14}$ By contrast, Byron sought to introduce his British readership to Romaic language and literature in order to prove that Modern Greek culture was too worthy of scholarly inquiry and to demonstrate how a study of Romaic culture gave readers a better impression than did classical studies of the everyday realities of contemporary Greece.

\section{Byron's Response to the Edinburgh Review}

In "Note III" of Childe Harold's Pilgrimage II, written on 17 March 1811, Byron mentions that he has received the $31^{\text {st }}$ edition of the Edinburgh Review and read the journal's review of Korais's translation of Strabo. Byron, staying at the Capuchin Convent in Athens, feels himself to be in a privileged position to comment on Modern Greek print culture and tells his readers that

\footnotetext{
${ }^{13}$ For an overall analysis of the Greek language's development, see Geoffrey Horrock, Greek: A History of the Language and Its Speakers. For spoken Greek in the Ottoman Empire and its development during the period specifically, see Chapter 14: "Spoken Greek in the Ottoman Period" (379-412); for more on language disputes in Greece, see Chapter 17: “The Language Question and its Resolution" (438-470).

${ }^{14}$ This plan for purifying the Modern Greek was in fact Korais's and led to the establishment of katharevousa as Greece's official language after the Greek War of Independence. At the time of the review, katharevousa would have been in its early stages and therefore, the writer for the Edinburgh Review would have been unfamiliar with it Byron, too, had not heard of katharevousa as he does not in "Note III" correct the journal's critic but instead writes that "The reviewer mentions a plan 'we believe' by Potemkin for the purification of the Romaic, and I have endeavoured in vain to procure any tidings or traces of its existence" (187-88; 2 nd ed.).
} 
his work acts as a response to the Edinburgh Review's account. He states, "[o]n those remarks I mean to ground a few observations, and the spot where I now write will I hope be sufficient excuse for introducing them in a work in some degree connected with the subject" $(181 ; 2$ nd ed.). His "few observations," which amount to a polemical response to the Edinburgh Review critic's historical and cultural biases, make up the remainder of the extensive "Note III" and "Appendix."

In his "Note III" and "Appendix," Byron demonstrates that, contrary to the Edinburgh Review's claims, Greece has a thriving print culture (despite its political condition) and that Romaic is more than just a corrupted form of Ancient Greek. Byron's explicit objective is to illustrate how culturally ignorant and insensitive the Edinburgh Review is in its assessment of Modern Greek language and literature. As someone who was in Greece, and who had access to Romaic texts, Byron was in an ideal position to contradict the Edinburgh Review. Perhaps more significantly though, Byron's "Note III" and "Appendix" provide his readers with an approach to understanding the Modern Greeks that deviates from both mishellenic and philhellenic writings of the late eighteenth and early nineteenth centuries.

In his article "The Image of Greece in Childe Harold's Pilgrimage and Don Juan," Stephen Minta argues that Byron's perspective of Greece changes between writing the first two cantos of Childe Harold's Pilgrimage. Minta characterizes this change as one in which Byron goes from trying to comprehend Greece as an outsider to understanding it as an insider. When Byron first traveled to Greece, he adopted the conventional view that the present-day country was "a mere backdrop to the glories of what is long gone" (179). Byron is at first unable to describe Greece without making recourse to his classical education. This changes, however, once the poet familiarizes himself with the country: 
In Canto II we find some development in the depiction of Greece... The attitude of the interested, cultivated, traveller and poet gives way to an emotional identification.... Where, in the beginning, a sense of cultural loss simply ties back into England and a public school education, the materiality of Greece, the heat and dust, the reality of sexual liberation, the physical confrontation with the literary debris of the classroom: all of this creates a growing emotional attachment, and a search for appropriate ways of rendering that attachment. (185)

One of the things Minta emphasizes here is that Byron, while in Greece, transitioned from ethnocentrically appreciating Greece's cultural legacy to immersing himself in Greek culture and embracing the country's contemporaneity. For Minta, this change is represented by the poet's increased awareness of Greece's social and physical realities. Once Byron had situated himself in the country, the poet strove to understand "the materiality of Greece" apart from the ancient world, which involved becoming educated about the social, political, cultural, and sexual realities of the Ottoman-controlled territory.

Byron's "Notes to Canto II" and "Appendix," in which the poet focuses predominantly on the material reality of Modern Greek culture, exemplify this transition that Minta observes; indeed, there are even discernible shifts in Byron's thoughts about Greece from one note to the next, although they were written only months apart. In challenging the Edinburgh Review's inadequate evaluation of Modern Greek literature and language, Byron depends upon his experiences travelling throughout Greece and, naturally, the more time that has passed, the better able he is to draw from his knowledge of the country's contemporary reality and to move away from a purely classicized vision of Greece. So, when the Edinburgh Review claims that Modern Greek works are "few in number" or that the country's political condition prevents 
intellectualism, Byron can use his acquaintanceships with learned Greeks, his personal reading of Greek texts, and his own research at the Capuchin Convent to discount these claims. Byron's focus on a multifaceted Romaic literature allows the poet to suggest to his readers that the Greeks are a dynamic people with whom it is worth becoming better acquainted and, more importantly, that Modern Greece's literary culture gestures toward future liberation for Greeks.

During his stay at the convent, Byron took Greek lessons with an Athenian tutor named Ioannis Marmarotouris. Although Byron makes scant reference to Marmarotouris in his personal correspondence, Leslie Marchand notes that the tutor was a leader amongst the Greek revolutionary patriots and that his political leanings likely influenced Byron's own feelings about Greek independence (Portrait 94). The fact that Marmarotouris was a member of a group of patriots who supported Greek independence is an important one, I think, because it compels us to consider how Byron's relationship with the tutor influenced which vernacular Greek texts Byron read, how he read them, and why he chose to translate them. Some of the texts Byron read, studied, and translated under Marmarotouris's tutelage were, I suggest, chosen for their liberal and revolutionary political perspectives and would have forced the young poet to reflect upon the convergence between print, literature, and politics. In fact, in one of Byron's rare references to Marmarotouris, it is clear that the Greek tutor thought literature could be an agent for change in his country: "I am entrusted with a commission by a Greek of Athens named Marmarotouri to make arrangements, if possible, for printing in London a translation of Barthelemi's Anarcharsis in Romaic, as he has no other opportunity, unless he dispatches the MS to Vienna by the Black Sea and Danube" ("Note III" 186; 2nd ed.). The fact that Marmarotouris wanted to publish a French Enlightenment text into vernacular Greek was radical enough as it was: the Greek revolutionary hero Rigas Velestinlis, executed by the Ottomans in 1798 for inciting insurrection 
amongst his people, had previously published the fourth volume of the novel. However, his choice of Jean-Jacques Barthélemy's Voyage du Jeune Anarcharsis en Grèce (1787)—a text set in ancient times and about a young Scythian who travels throughout Greece and celebrates Greek literature, customs, politics, and economy — makes even clearer Marmarotouris's politicallymotivated intention to instruct his fellow Greeks about their glorious ancient past. And just as Marmarotouris made it his goal to introduce Enlightenment ideas to his fellow Greeks, he would have, I suggest, had a hand in acquainting Byron with political, secular Romaic texts that influenced the young poet's opinion about the value of Modern Greek literature.

Some of the Romaic texts Byron translates for the "Appendix" while studying with Marmarotouris are, perhaps unsurprisingly, deeply political. The most famous of these texts was the Greek version of La Marseillaise entitled " $\Delta \varepsilon \tilde{\tau} \tau \varepsilon \pi \alpha \tilde{\alpha} \delta \varepsilon \varsigma \tau \tilde{\omega} v v^{'} E \lambda \lambda \eta \dot{\eta} \nu \omega$," ("Sons of Greeks, Arise!”) which Byron incorrectly identified as Rigas Velestinlis's "Greek War Song." ${ }^{15}$ Byron would have first heard the poem - which incites Modern Greeks to begin a revolution against their Ottoman oppressors - when he and Hobhouse stayed with Andreas Londos in the Peloponnese (it was Londos who first mistakenly attributed the work to Rigas). Although the source text from which Byron translates the poem is unknown, Solomou speculates that he likely "obtained a copy of the song either in print or in the form of a broadsheet or had the song copied out for him at his request" (180). Byron was probably tempted to translate "Sons of Greece, Arise!" because it was popular amongst Greek commoners in the oral tradition and because it expressed sentiments about Greek liberation similar to his own. Such lines as "A $A \varsigma \alpha \tau \eta ́ \sigma \omega \mu \varepsilon v$

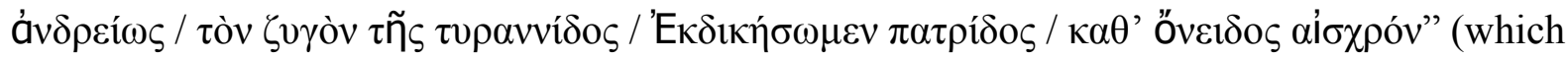

\footnotetext{
${ }^{15}$ As Beaton relates, "Rigas had indeed been the author of a 'famous war song', but this had nothing to do with the imitation of the 'Marseillaise' in crude form of semi-learned Greek that Hobhouse transcribed into his diary at Vostitsa. Later, Byron would make his own translation of this doggerel, which he, too, thought was the work of Rigas" (Byron's War 9).
} 
Byron translates as "Then manfully despising / The Turkish tyrant's yoke, / Let your country see you rising, / And all her chains are broke") are later echoed in Childe Harold II. ${ }^{16}$

Another piece Byron chose to translate a section from was Rossanglogallos (Russ-AngloGaul). As Byron tells his readers, he does not translate this work-which he calls "contemptible as a composition" ("Appendix" 276; 2nd ed.)—for its literary merit, but rather because the poem provides a typical example of Romaic meter (15 ictuses; heroic couplets). Another likely reason Byron chose to translate the poem was its political content: the poem follows a Russian, an Englishman, and a Frenchman who ask various Greek personages (including a Bishop, a Prince, and a Merchant) why they do not do more to help Greece, only to be told by these men that they benefit financially by remaining under Ottoman rule. The three foreigners then meet a female personification of Greece who condemns not only her corrupt compatriots, but the Russians, English, and French who have failed to help Greece overcome the Ottomans. The poem may not be a polished piece of literature, but its portrayal of various class levels in Greek society and examination of why Greece remained under Ottoman rule would certainly have appealed to Byron. In fact, the lines he translated into English are those in which the Russian, Englishman, and Frenchman ask a Greek patriot how he endures his slavery and why Greece still remains under Ottoman yoke.

Other works Byron reads and translates during this period are less overtly political. These include a Romaic love song entitled "M $\pi \varepsilon ́ v \omega \mu \varepsilon \sigma$ ' $\tau$ ò $\pi \varepsilon \rho ı ß o ́ \lambda \imath "$ " ("I Enter the Garden of Roses") which features a protagonist named Haidee (the name of the heroine in cantos 2 to 4 of Don Juan, we should note) and a poem Byron gives the title "Translation of a Romaic Love Song"

\footnotetext{
${ }^{16}$ Cf. Canto 2, stanza 76: "Hereditary bondsmen! know ye not / Who would be free themselves must strike the blow? / By their right arms the conquest must be wrought? / Will Gaul or Muscovite redress ye? no! / True, they may lay your proud despoilers low, / But not for you will Freedom's altars flame. / Shades of the Helots! triumph o'er your foe! / Greece! change thy lords, thy state is still the same; / Thy glorious day is o'er, but not thine years of shame" (720-28).
} 
which was published in the seventh edition of Childe Harold's Pilgrimage in 1814. And although Byron did not translate it for the "Appendix," he was made aware of (The Shepherdess) - a poem Solomou claims the poet borrowed from for the pastoral scenes in Don Juan (283) — by John Galt in 1810, as Byron's 4 October letter of that year to Hobhouse indicates (BLJ 21-22). ${ }^{17}$ Finally, Byron clearly knew not only about written Modern Greek literature, but also about oral Romaic traditions, as one of his notes to The Giaour makes clear: "The circumstance to which the above story relates was not very uncommon in Turkey ... The fate of Phrosine, the fairest of this sacrifice, is the subject of many a Romaic and Arnaout ditty . . . I heard it by accident recited by one of the coffee-house story-tellers who abound in the Levant" (423). As I mentioned, "I Enter the Garden of Roses," "Translation of a Romaic Love Song," The Shepherdess, and "the Romaic and Arnaout ditty" are not explicitly political in character. It would be difficult to prove that Byron saw in these works inspiration for Greek liberation, as he would have in "Sons of Greeks, Arise!" or Rossanglogallos. However, these works are significant because they would have contributed to the poet's knowledge about the range of Romaic literature written in vernacular that was available in the early nineteenth century, as well as reveal the scope of Byron's familiarity with Romaic literary culture that he would go on to promote in "Note III" to Childe Harold II and the "Appendix."

Finally, one other major source of Byron's knowledge about Modern Greek writers was A Supplement to the Ecclesiastical History of Meletius by the eighteenth-century Greek writer and publisher Georgios Vendotis, a text the poet had access to in the Capuchin Convent (and which he, mistakenly, attributed to Meletius, the author of the three volume Ecclesiastical

\footnotetext{
${ }^{17}$ John Galt and Byron first met in Gibraltar in 1809. Galt travelled to Greece in 1810-11 and published in 1813 his travelogue Letters from the Levant (London: T. Cadell and W. Davies, 1813) about his travels there.
} 
History to which Vendotis added the supplement).${ }^{18}$ Vendotis's catalogue of fifty-five writers that Byron consults (entitled "On the educated men of the East in the current century") provides the British poet with an intriguing assortment of Greek writers, including ecclesiasts (18), grammarians (4), translators (3), poets (2), historians (2), and political scientists (2). Two of the writers had even composed treatises on Voltaire—one pro, the other anti. Undoubtedly, Byron would have seen in this group of writers a dynamic literary network in Greece, one that contributed to his view that Greece's intellectual culture could have wider political, social, and nationalistic implications.

Interesting still is which of the fifty-five writers Byron names in his "Appendix." His list includes Neophitus, a grammarian and political scientist; Prokopius of Moscopolis, who compiled a catalogue of intellectual Greeks; Seraphin of Periclea, who wrote works in a Turkish dialect but using the Greek alphabet; Eusathius Psalidas, a physician who made a tour of England; Kallinikus Torgearus, a poet and prose writer; Anastasius Macedon, a member of the Royal Academy in Warsaw and church biographer; Demetrius Pamperes, who wrote on Hesiod and who also composed (unspecified) tales; Meletius, a geographer and historian; Dorotheus of Mitylene, an Aristotelean philosopher whose "Hellenic works are in great repute" (“Appendix" 270; 2nd ed.); Marinus Count Tharboures, a professor of chemistry in Padua who published an account about a marine animal and a treatise on iron; Marcus Tharboures, a mechanic; and the

\footnotetext{
${ }^{18}$ Pioneered in the early fourth century A.D. by Eusebius, the bishop of Caesarea, ecclesiastical histories were written for the purpose of documenting the history of the Christian church and religion (Kazhdan 671). However, as centuries progressed, ecclesiastical histories began to combine church history with political and societal history more broadly (Kazhdan 671). That is, ecclesiastical histories began to portray secular events from a religious perspective. Even so, Georgios Vendotis's A Supplement to The Ecclesiastical History by Meletius is atypical in that it documents literary works, both religious and secular. One reason for Vendotis's use of an ecclesiastical history to document secular works might have been to avoid persecution by Ottoman authorities, who allowed only the open circulation of printed religious texts in Greek, and not secular ones. Further to this, some of the 55 authors mentioned in the catalogue Byron consults were officially men of the Church (under the jurisdiction of the Ecumenical Patriarchate) who were teachers at official Greek ecclesiastical schools, but whose works also included grammars, books on Greek history, and other secular topics. In other words, these men's religious positions provided them with a cloak to write secular works.
} 
translators Georgios Konstantinos and Georgios Vendotis who published lexicons. There are a couple of reasons, I suggest, that Byron chose to highlight a cosmopolitan group of Greek intellectuals whose works are secular rather than focus on the religious writers in Vendotis's catalogue, who far outnumber them. For one, most religious compositions in Greece were written in an archaized form of Greek (Byzantine koine), and as Byron indicates in "Note III" and the "Appendix," his focus is on Romaic writers. Second, by featuring the writers that he does, Byron is able to introduce his readers to Modern Greek literary genres, and a foreign scholastic culture, formerly unknown to Britons. Third, by highlighting Modern Greek writers who used vernacular language in their works, Byron could disprove the Edinburgh Review's claim that contemporary Greeks had failed to produce a substantial Romaic literary culture. By focusing on the writers he does, Byron demonstrates the breadth of Modern Greek literature, as well as confirms that the Romaic language could be used for literary and scholarly purposes.

In the "Appendix," Byron concludes from his reading and research that Greece's intellectual culture is impressive, especially considering its political condition:

Amongst an enslaved people, obliged to have recourse to foreign presses even for their books of religion, it is less to be wondered at that we find so few publications on general subjects, than that we find any at all. The whole number of the Greeks, scattered up and down the Turkish empire and elsewhere, may amount, at most, to three millions; and yet, for so scanty a number, it is impossible to discover any nation with so great a proportion of books and their authors, as the Greeks of the present century. (267; 2nd ed.)

Byron even counteracts the anticipated rebuttal by those who might note that most of these texts are religious tracts and therefore "good for nothing" by claiming that, unlike the British or 
French, "A Greek must not write on politics, and cannot touch on science for want of instruction; if he doubts, he is excommunicated and damned" $\left(268 ; 2\right.$ nd ed.). ${ }^{19}$ Also, despite his observation that, of the fifty-five writers catalogued in A Supplement to the Ecclesiastical History of Meletius, "not above fifteen should have touched on any thing but religion" (268; 2 nd ed.) (it is actually thirty), Byron knew that Greeks were producing a wide range of secular texts within a variety of genres, as demonstrated by his reading and translation of certain works, and his cataloguing of others. These secular works, together with the religious, proved to Byron that Greeks in the last century alone had produced many texts and that, therefore, intellectuality was alive and well amongst them. As Byron writes of a student of his Yaninian acquaintance, Athanasios Psalidas: "There is now in Athens a pupil of Psalida's, who is making a tour of observation through Greece: he is intelligent, and better educated than a fellow-commoner of most colleges. I mention this as a proof that the spirit of inquiry is not dormant amongst the Modern Greeks" (“Note III” 190; 2nd ed.). ${ }^{20}$

\footnotetext{
${ }^{19}$ Although Byron suggests that his readers might think Greek religious writing is "good for nothing," this does not necessarily reflect his own position on the Greek Orthodox Church. Marius Byron Raizis argues that, although his allusions to the Greek Orthodoxy are few, "[i]n his letters we ... find some references to Greek patristic writers and scholars ... that are of considerable cultural and psychological interest ... Some fundamental theological and doctrinal issues also intrigued him, especially details in accord with his own rebellious nature" (90). For more on this topic see Marius Byron Raizis, "Lord Byron and Greek Orthodoxy," Balkan Studies 27.1 (1986): 89-104.

${ }^{20}$ Although Byron does not name this student, his travels interestingly coincide with the development of Psalidas's vernacular language reform program. Peter Mackridge writes that

Around 1811, a new development was taking place for the first time in what was later to become part of the Greek state. This was a radical new educational and linguistic reform project, which has come down to us in the form of unpublished correspondence between a number of enlightened men, though their letters were copied and sent or read out to a larger circle. The reforms were proposed chiefly by two men in Yannina, the capital of the increasingly independent province of the Ottoman empire governed by Ali Pasha from Tepelene in Albania. These were Athanasios Psalidas (Yannina 1767-1829), the headmaster of one of the local Greek schools, and Vilaras, whose travels on campaign to various parts of Greece as personal physician to Ali's son Muhtar Pasha had brought him into close contact with the popular culture of rural Greece. (145)

Byron does not say so, but one wonders if he knew anything about this correspondence. Interestingly, in his correspondence with Vilaras, Psalidas "constantly talks of autonomy as a prerequisite for the development of the arts and sciences in Greece, and he may have envisaged complete political independence, but he no doubt saw autonomy from the cultural hegemony of antiquity as being equally necessary" (Mackridge 146).
} 
It was precisely because Byron had become familiar with Greek intellectual culture while in Greece that he could dismantle the Edinburgh Review's account of Modern Greek literature. Particularly offensive to the poet—who by the time of his riposte felt himself an insider in Greece - was the journal's claim that Korais, an outside Greek, was the best representative of Modern Greek literature. Byron in fact takes a few calculated hits at Korais in "Note III" that are ultimately more about rejecting the Edinburgh Review's framing of Modern Greek literature and language than about slighting the Greek writer. Byron writes that Korais "is not considered by his countrymen equal to some who lived in the last two centuries" $(183 ; 2$ nd ed.) and "[t]hat Coray may err is very possible; but if he does, the fault is in the man rather than in his mother tongue" (193; 2nd ed.). By claiming that Korais is not as popular in Greece as he is abroad and by suggesting that his skills as a translator should not be associated with the Romaic language, Byron effectively shifts the focus of the conversation about Modern Greek literature and language away from diasporic Greeks to those living in Ottoman Greece.

In "Note III" and the "Appendix," Byron goes to great lengths to teach his readers about current developments in Modern Greek language, literature, and print culture happening in Greece. He explains that the Napoleonic Wars have closed down the European print networks through which Greeks received their books ("Note III" 185; 2nd ed.); he describes the country's most popular genres of literature, including theatre, satire, and folk songs ("Note III" 185; 2nd ed.) and in the "Appendix" provides written excerpts and translations from Greece-based Romaic writers that exemplify these genres; he discusses the (now debated) "secret schools" where Greeks became educated without the Ottomans' knowledge and explains that there is in Yanina "a flourishing school under the direction of Psalida" ("Note III" 190; 2nd ed.); and importantly, he chastises the Edinburgh Review for suggesting that Romaic Greek is merely "“a powerful 
auxiliary" for classical scholars, a position Byron claims serves to make the Modern Greek language useful "to every body except the only person who can be thoroughly acquainted with its uses"-i.e. a Modern Greek ("Note III" 192-93; 2nd ed.). Just as he had done with Lord Elgin in Childe Harold II when he deemed him "The last, the worst, dull spoiler" (94) and "Cold as the crags upon his native coast" (102), here Byron censures a fellow-Briton for appropriating Greek culture. Except this time, instead of a diplomat plundering the Parthenon sculptures, we have a writer who suggests that classical scholars like himself should lay claim to the Modern Greek language mainly to bolster their own work, a belief that stems from his exclusive engagement with classical texts. Byron, rather than considering his own personal gain, was interested instead in how Britons' knowledge about Modern Greek literature and language could help them to understand better Modern Greece's current political condition and to strengthen Greek-British intercultural relations.

\section{Language Debates and Greek National Identity in the Early Nineteenth Century}

Byron's "Note III" and "Appendix" were written at a crucial point in Modern Greek history, when questions about Greek national identity had come to the forefront in anticipation of the 1821 Greek War of Independence. "The period between the late eighteenth century and the early nineteenth," Mackridge writes, "is marked by the transition from the 'genos of the Romaioi' to the Hellenic ethnos" (52). Before this period, and beginning in late antiquity, the term Hellene was associated with paganism; for roughly one and a half millennia (from the time of Constantine the Great in the fourth century A.D. until the early nineteenth century) most Greeks

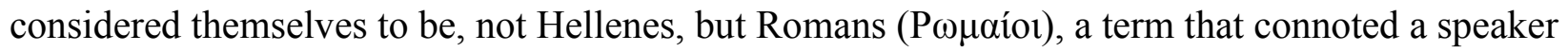
of Greek and an Orthodox Christian (Kaldellis 45). Alternatively, Greeks would have identified themselves based on their immediate familial or tribal groups (Wallace 188). By defining 
themselves in these ways, Greeks were "able to identify their extraregional ties and to distinguish themselves from their Muslim leaders" (Leontis 6). However, during the early nineteenth century and with greater intensity during the Greek War of Independence, increasingly more Greeks, as they became exposed to European scholarship that celebrated Ancient Greece, began to define themselves as Hellenes in order to emphasize their ancient ancestry.

Byron was in Greece as increasingly more Greeks were beginning to think of themselves as belonging to a Hellenic nation (ethnos) rather than to a heritage or bloodline that linked them back to the Eastern Roman Empire and Greek millet (Romaic genos). This transition, however, was anything but immediate or clear-cut. From 1809 to 1811, when Byron was travelling through Greece, the parameters of Greek nationalism were in the process of a jarring shift and thus open to debate: Hellenism in early nineteenth-century Greece was by no means a popular or dominant ideology. Accordingly, this allowed Byron to move away from the predominantly classical impulses of European scholarship and to think about Modern Greek culture apart from the ancient Hellenic past, something that would come to seem impossible for almost all European writers once Greece became a nation two decades later.

The fact that Byron chose to focus on vernacular print and literary culture as proof of Modern Greece's cultural advancements is especially significant once we account for the ways in which language debates intersected with discussions about Modern Greek national identity in the years preceding the War of Independence. As Benedict Anderson has argued, the late eighteenth century in Europe saw the emergence of the modern-day concept of nationalism, the development of which depended on the convergence between print-capitalism and strategic language policies. According to Anderson, the combination of language and print allowed millions of geographically-isolated people to feel an affinity through their shared reading, an 
affiliation that eventually developed into an imagined national community. This imagined community was especially pertinent to national liberation movements of the early nineteenth century in which, unsurprisingly, “"national print-languages' were of central ideological and political importance" (Anderson 69).

Admittedly, Anderson's argument that national liberation movements depended upon the connectedness between language and print to succeed is not entirely convincing when applied to the Greek War of Independence. As Mackridge remarks, "the popular language was largely marginalized until very late in the nation-building process" (11). Mackridge also notes that not only language, but shared religion, geography, history, descent, and customs contributed to Greeks' sense of national identity. Further, John Joseph makes the keen observation that Anderson "gives all his attention to how languages shape national identities, but none to how national identities shape languages, which they do profoundly" (13). In spite of these valid and thought-provoking responses to Anderson, I find credible Anderson's more general argument that early nineteenth-century Greek writers' discourses concerning the Modern Greek language —influenced by "the prodigious labours of German, French and English scholars" (74) which made widely available classical Greek works - impacted the general Greek populaces’ sense of national identity before, during, and after the war. Anderson's discussion of the confluence between print and nationalism becomes relevant to the historical moment in early nineteenth-century Greece that Byron was witnessing when we consider language reform programmes such as Korais's and Kordrikas's which found popularity by being published and circulated amongst literate Greeks who were, at least in part, responsible for stimulating a desire for independence amongst Greeks. 
As I have been arguing, "Note III" and the "Appendix" represent Byron's attempt to introduce his British readership to Modern Greece and, specifically, to a vernacular literature and language which he felt best exemplified contemporary Greek culture. However, despite Byron's efforts to promote Romaic culture to a broader audience, the reality was that, by 1812, Europeans were already more preoccupied with a conception of Greece that harkened back to the classical past, a preoccupation that in fact impacted Greece's own language policies. During the 1810s and 1820s in Greece, the two main national language models fighting for ascendancy were Korais's katharevousa (which eventually triumphed and became Greece's official language after the war) that looked to Classical Athens as a linguistic example and Panayiotis Kodrikas's model which instead privileged the Byzantine linguistic tradition. The two models had at least two aspects in common. First, both were heavily advertised through the two writers' published works and targeted toward specific power bases: Korais's to intellectuals and entrepreneurs (Anderson 81) and Kodrikas's to the Orthodox Church establishment (Mackridge 138). Second, each considered the everyday spoken language of the Greek people (Romaic) an impossible candidate for Greece's national language.

This is not to say that advocates of Romaic Greek had not developed national language models of their own. In fact, Psalidas (a teacher whom, we recall, Byron had met in Yanina) and his colleague Vilaras created a language and education reform program in the early 1810 s which promoted "a practical and secular education" that would "be based on the spoken language" (Mackridge 146). However, this program remained unpublished during their lives and, by the time the Greek war had begun, was not considered a potential model for Greece's eventual national language, as were Korais's and Kodrikas's programs. The reason for this, I suggest, relates to the shift from Romaic genos to Hellenic ethnos that I have documented. Greek national 
identity in many ways became more exclusive and less negotiable as Greeks began to adopt Romantic ideas about what constitutes nationalism—including territory, people, language, custom, and descent—and to harken back to their ancient past as a strategy to make Greek independence appeal to the rest of Europe. ${ }^{21}$ As Basil C. Gounaris attests, "[d]efining Greek citizenship and identity in terms of language, religion, and education, the modernization of the future and Hellenization of the past were the basic requirements of the Greek national agenda in the nineteenth century" (145). Vernacular Greek, in turn, became discordant with the newly formed Greek state which "was presented as a rebirth of the ancient Greek civilization in a new and stronger political form" (Mourtisen 48).

The fact that Byron defended Romaic culture at a point when it was becoming overwhelmed by a Hellenic model of Greece that both Greeks and Europeans were rallying behind en masse forces us to reassess the poet's position on Greece and the character of his philhellenism. Beaton suggests that, during the time of Greece's development into a Hellenic nation, "[i]t is an ironic result of the dominance of the European powers and their ideology over Greece ... that the terms in which the Greeks sought to proclaim their own specific identity, as distinct from the rest of Europe, were all adopted piecemeal from the west" ("Romanticism in Greece" 95). If this was the case, Byron's privileging of and advocacy for Romaic literature and language in "Note III" and the "Appendix" can be read as the poet's attempt to demonstrate to his readers how Modern Greeks had already begun to define their culture and to establish their (national) identity on their own terms. Hellenic Greece was not the only Greece about which

\footnotetext{
${ }^{21}$ As Henrik Mourtisen argues, Greece's evocation of its glorious past was not a uniquely Greek experience but, rather, a widespread phenomenon in Europe at the beginning of the nineteenth century. He writes that "[f]rom its first inception, the idea of the nation had a strong historical dimension. It was inextricably linked to the early development of historicism, which was the reinvention of the past as a continuous, ever-changing process of creation ... The intimate connection between nation and history meant that the Romantic nation automatically found itself at the centre of a grand narrative that traced the stages of its development and — ideally —its steady progress towards perfection" (45). What was distinct about Greece's appeal to the past, however, was how influential and pervasive the "classical model" became in helping to create Greek national identity.
} 
Britons should know and indeed, as Byron suggests, perhaps not even the best model for a future Greek nation.

"Note III" and the "Appendix," Childe Harold II, and Greek-British Cultural Relations "Note III" and the "Appendix," were not, however, the sections of Childe Harold's Pilgrimage that made Byron famous; instead, it was Cantos I and II, to which "Note III" and the "Appendix" were appended, that did. Although Byron does not reflect upon Romaic culture in the poem proper, it is crucial to examine how his discussion of Romaic literature and language in "Note III" and the "Appendix" intersects with his meditations upon Ancient Greece's cultural legacy and Modern Greece's political realities in Childe Harold II if we are to understand the ways in which his work sought to influence British impressions of Greece. As Timothy Webb argues, “Childe Harold's Pilgrimage is made up by the whole range of its constituent parts" (128) and readers must focus on all of them (including the prose notes) to best understand Byron's work. Indeed, Byron's general preoccupation with contemporary Greece and Greek national identity in "Note III" and the "Appendix" is also present in Childe Harold II. I suggest that Byron decided to yoke these three works because they are mutually informative: Childe Harold II's rousing call for Greek insurrection is clarified and tempered in "Note III" and the "Appendix" while, on the other hand, "Note III" and the "Appendix" can help readers understand more clearly Byron's views in Childe Harold II concerning Britain's relationship with Modern Greece in the early nineteenth century. ${ }^{22}$

In "Songs and Stanzas, Stanzas and Songs: Greece in Childe Harold and Greece in Don Juan," Peter Cochran submits that Byron's discussions of Greece in Childe Harold II and in the prose notes are incompatible, revealing the poet's uncertainty regarding the Greeks. According to

\footnotetext{
${ }^{22}$ Initially, Byron had thought of placing the notes after his poem Hints from Horace. See BLJ II 75.
} 
Cochran, while the poetry is the typical classical philhellenic fare, the corresponding "Notes" reveal Byron's "banal scepticism" (177) about the Greeks and their bid for freedom. Indeed, Byron writes in "Note II" that "[t]o talk, as the Greeks themselves do, of their rising again to their pristine superiority, would be ridiculous" (173; 2nd ed.) and, in "Note I" (which Cochran quotes), that "[t]he Greeks will never be independent ... and God forbid they ever should be! but they may be subjects without slaves. Our colonies are not independent, but they are free and industrious, and such may Greece be hereafter" (170; 2nd ed.). The apprehension Byron reveals he has about Modern Greece's future in his notes even permeates Canto II. He tells Athena that her "men of might" (11) are "Gone—glimmering through the dream of things that were" (12); suggests that each hero of the past "now not one of saddening thousands weeps, / Nor warlike worshipper his vigil keeps" (40-41); and declares “nor ev'n can Fancy’s eye / Restore what time hath labour'd to deface" (87-88). In such lines, Byron can be accused of idealizing the ancient past at Modern Greeks' expense. Perhaps most famously, Felicia Hemans in her 1817 poem Modern Greece channels Childe Harold II and seizes upon such descriptions in order to support her case that the British, and not the Modern Greeks,- -whom she deems "a meaner offspring" (550) - are the true ancestors of the Ancient Greeks, and therefore deserving of the Parthenon (Elgin) marbles. ${ }^{23}$

However, although Byron's allusions to Ancient Greece in Canto II and the scepticism about Greek freedom he reveals in his notes to the poem undoubtedly threaten to overshadow the poet's philhellenism, they do not negate it. In fact, I argue that Byron references Ancient Greece in Canto II not only to glorify the past (which he does) but also partly to emphasize its obsolescence. Indeed, most of his references to Ancient Greece in the lines from Canto II quoted

\footnotetext{
${ }^{23}$ Remarkably, Hemans alters her position on Modern Greece after the Greek War of Independence begins in 1821, publishing many poems in support of the Greeks, including "The Voice of Scio" (1823), "The Sisters of Scio" (1830), and "The Bride of the Greek Isle" (1825) — the latter of which I discuss in Chapter 3 of this dissertation.
} 
in the previous paragraph signify that it has been forgotten by the Modern Greeks and emphasize that, even though the ruins of the past are present, the culture they once represented is not. In the line “nor ev'n can Fancy's eye / Restore what time hath labour'd to deface” (87-88), Byron even denies that ekphrastic vision — most commonly associated with the male Romantic poet—can "restore" the bygone past. The ruins of the past may be visible but no Ancient Greece will be rebuilt from them in the modern age.

Instead of Ancient Greek culture, Byron invests great redemptive power in Greece's natural sites which resist the ravages of time: "Each hill and dale, each deepening glen and wold / Defies the power which crush'd thy temples gone: / Age shakes Athena's tower, but spares gray Marathon" (834-36). For Byron, cultures perish, while nature continues on; or, in his own words, “Art, Glory, Freedom fail, but nature still is fair" (827). Byron's objective in Childe Harold II is not to promote an absolute revival of Ancient Greece but instead to demonstrate how the Greek topos, as a memorial site, can inspire contemporary political change. The poet's discussion of Ancient Greece is meant to foreground Modern Greece's enslaved state, and not to encourage the reconstitution of the classical past in contemporary Greece. As Dino Felluga writes, “Byron’s evocation of the $u b i$ sunt tradition ... transforms into an ubi sunt of the hic et nunc, a call to arms directed to the present, with an eye to the future and not the past" (157).

By recognizing that the poet's experiences in the country inflect his discussion of (Ancient and Modern) Greece in Canto II, I argue we can begin to see the poem (and Childe Harold's Pilgrimage as a whole) less as a work in which Byron merely popularized a clichéd version of Greece as an ancient memorial site and more so as one in which he attempts to comprehend and represent a foreign people to his readers. As I have been arguing, "Note III" and the "Appendix" give Byron the opportunity to express his own views on Modern Greece and, at 
a period when Greece's relationship with Britain was undergoing a dramatic shift, to introduce his readers to a Romaic culture about which very few Europeans knew. Although in the poem proper Byron is less explicit about his knowledge of Romaic Greece, and seemingly disparages the Modern Greeks by referencing their unfamiliarity and incompatibility with the heroism and glory of the ancient past, I instead argue that readers need to see the poetry and prose of Childe Harold II as being interdependent in order to understand that Byron emphasizes the differences between Ancient and Modern Greece so as to help contemporary Greeks avoid being held to unrealistic standards. Byron's allusions to Ancient Greece in Childe Harold II may seem as if they represent the typical response to the contemporary country, in which a (usually) learned gentleman ignores the modern country in favour of "discovering" remnants of the ancient past in the present, but they do not. Indeed, Philip W. Martin suggests that, if Byron does retreat into the ancient past in Canto II, this refuge is meant to be read ironically: "Here is a poem which announces itself as an indulgent and sacred journey into the arcane and quaint, a poem which will perhaps withdraw into the past, but, of course, the opposite proves to be the case. The 'pilgrimage' forces a radical revision of the liberal historical view" (86). Read in this way, Byron's allusions to the ancient past are used to draw greater attention to the modern country's enslavement, a predicament that was in 1812, when the poem was published, still largely ignored by Europe's great powers. In fact, I suggest that one of the reasons Byron invokes the ancient past in Canto II is to comment on British-Greek cultural relations.

In arguably the poem's most famous passage, Byron chastises Lord Elgin for plundering the Parthenon Marbles but he does not do so as an admirer of art. $^{24}$ By his own admission, Byron

\footnotetext{
${ }^{24}$ In stanza 11 Byron calls Lord Elgin "The last, the worst, dull spoiler" (94) and writes "England! I joy no child he was of thine: / Thy free-born men should spare what once was free" (96-97). In stanza 12, Byron suggests that "His mind as barren and his heard as hard, / Is he whose head conceiv'd, whose hand prepar'd, / Aught to displace Athena's poor remains" (103-5).
} 
is not invested in Greece's ancient monuments as works of art and in fact calls them "Phidian freaks, / Mis-shapen monuments, and maimed antiques" (English Bards and Scotch Reviewers 373-74). I argue that Byron criticizes Elgin because he sees the ambassador as having set a bad precedent for intercultural relations between Britain and Greece. Indeed, Byron insists throughout the poem that Britons should treat the Greeks with respect. He writes that "Thy freeborn men should spare what once was free" (97); asks "What! shall it e'er be said by British tongue, / Albion was happy in Athena's tears?" (109-10); and asserts in a note to the poem "[D]o not think the honour of England advanced by plunder, whether of India or Attica" (133; 2nd ed.). The poet insists in these three quotations that a Britain which considers itself to be free should know better than to help oppress an already enslaved country and, by mentioning India in conjunction with Athens (Attica), makes it clear that he is correlating Elgin's plunder of the Acropolis with Britain's overall imperialist expansionist project. Byron solicits the ancient past in Childe Harold II, then, in part to discuss British foreign policy and Britain's relationship with contemporary Greece and to advocate for a cross-cultural association between Greece and Britain that differs from Britain's more imperialistic interactions with other countries.

Byron continues his discussion of Britain's relationship with Modern Greece in his "Notes to Canto II." As mentioned earlier, such lines as "To talk, as the Greeks themselves do, of their rising again to their pristine superiority, would be ridiculous" ("Note II" 173; 2nd ed.) and "The Greeks will never be independent ... and God forbid they ever should be! but they may be subjects without slaves. Our colonies are not independent, but they are free and industrious, and such may Greece be hereafter" ("Note I" 170; 2nd ed.) would not be typically associated with a philhellene. However, there is no reason to assume that either of these quotations is mishellenic. In fact, Byron is in the first quotation not so much interested in criticizing the Greeks as he is in 
deflating the rhetoric of Greek purists like Korais (not to mention British philhellenes) who suggested that the Modern Greeks could become perfectible by imitating the Ancient Greeks. And although Byron's sentiments are, rightfully, not popular today, his proposition in the second quotation that Greece should become a "colony" (most likely of the nineteenth century's Caput Mundi, Britain) and "free and industrious" before assuming independence is, while admittedly patronizing, also understandable when considered in its historical context.

If Byron's true opinion of the Greeks was that they were a degraded race who should not be emancipated, he would not have spent so much time in "Notes to Canto II" and the "Appendix" criticizing mishellenes like Cornelius De Pauw and William Thornton who "have debased the Greeks beyond their demerits" ("Note I" 170; 2nd ed.) and philhellenes like William Eton and Sonnini de Manoncourt who he says "have led us astray by their panegyrics and projects" ("Note I" 170; 2nd ed.). Indeed, the extent of Byron's philhellenism is difficult to gauge because he refuses to commit to one camp-in his discussion of the Greeks, as in so many other aspects of his life, Byron was stubbornly individualistic. The fact remains, however, that Byron in "Notes to Canto II" and the "Appendix" considers Greek liberty at great length. Part of that discussion, in turn, relates to Greece and Britain's future relationship and how Britain's learning about Greek culture can help reinforce it—an idea he had begun to consider when he was writing Childe Harold II. Even if Byron in "Note III" and the "Appendix" does not explicitly connect Modern Greek print culture with national freedom or make the spirited bid for Greek liberty that we see in Childe Harold II, the explanation is not necessarily that he had second thoughts about Greek emancipation. Instead, Byron's more tempered views in "Note III" and the "Appendix" can be attributed to a number of other factors, including an increased political pragmatism by the time he had begun to write his prose notes. 
By noticing that Byron in "Note III" and the "Appendix" speculates upon Modern Greek language and literature in conjunction with Greece's future as a nation and British-Greek intercultural relations, we also, I think, gain better insight into Byron's voyage to Messolonghi in 1823-24 to help rally British support for the Greeks in their bid for independence - a decision on the poet's part that in many ways connected Britain and Greece forevermore. In Byron's War, Beaton contends that Byron's 1823-24 mission to Greece had little to do with the physical war between Ottomans and Greeks and was instead more so about seeing "the very essence of Romantic poetry translated into politics" (139). Coupled with his desire to see his life's work actualized, Byron, in alliance with the Greek statesman Alexandros Mavrokordatos, wanted to ensure the internationalization of the Greek war and, in particular, Britain's involvement in Greece's bid for freedom. Beaton writes, "Byron and Mavrokordatos, together, were determined to tie the fortunes of the revolution into the economic and geopolitical future of the entire continent" (227). ${ }^{25}$ Byron's 1809-11 writings about Greece certainly lack the overt nationalism that Beaton sees in Byron's 1823-24 mission to Greece; this makes sense, considering the fact that nationalism was an ideology the poet discovered in the late 1810s in Italy (Beaton 56). However, Byron's early work regarding Greece can be seen to anticipate his second voyage to Greece insofar as his discussion of Romaic culture and Greece's future liberty is coupled with a consideration of the country's relationship with other nations, and namely, as I have been arguing, with Britain. Perhaps Byron did not have at his disposal the terms we have today-like

\footnotetext{
${ }^{25}$ Interestingly, Sydney Owenson too became acquainted with Mavrokordatos when she lived in Italy. As she writes in her diary in 1819: "The day before we departed we dined with the Prince or Hospodar of Wallachia, who is travelling with his charming family of three generations, his Prime Minister, and a number of his court! What I would have given if you had seen us in the midst of their turbans and beards! The Princesses and the sweet little children speaking nothing but Greek, and conversing with me by signs, all dressed in. Greek costume, and the servants in the beautiful Albanian dress! The men speak French like Parisians, and we have made up a great intimacy with Mavrocordato, the minister, who is young, handsome, and pleasant" (222). See Sidney Owenson, Lady Morgan's Memoirs: Autobiography, Diaries and Correspondence. 3 vols. Leipzig: Bernhard Tauchnitz, 1863. The Shelleys, too, were friends of Mavrokordatos, as I discuss in chapters three and four of this dissertation.
} 
international relations, for example — but it is clear that, even in 1809-11, he was preoccupied with Britain's knowing Greece better, one way of which would be through a knowledge of Romaic language and literature.

"The fact is," writes Byron to his readers in "Note II" to Childe Harold II, "we are deplorably in want of information on the subject of the Greeks, and in particular their literature, nor is there any probability of our being better acquainted, till our intercourse becomes more intimate or their independence confirmed" (177-78; 2nd ed.). Our being better acquainted; a more intimate intercourse; independence confirmed. Byron here seems to be gesturing toward a future relationship between Greeks and Britons in which the two nations would become more involved with one another as equals. And if Byron's letters are any indication, teaching his readers about Romaic Greek literature and language would be one way in which this kind of relationship would develop. In a series of letters written to Hobhouse in 1811, after he had returned to Britain from Greece, Byron becomes fixated with his "Notes" and "Appendix." $\mathrm{He}$ tells Hobhouse in one letter that his Romaic M.S.S. is to be "in labour of "Childe Harold"” and that he has "been sweating Notes to a large amount" ( $B L J 130)$. And in another letter, he tells Hobhouse "I am convinced that the more you say on the Romaic the better" (BLJ 135). In over 20 letters to various correspondents from 1811 to 1814, Byron shows intense enthusiasm for Romaic culture and stresses the importance of educating the public about the Modern Greek language. ${ }^{26}$ Those books Byron brought with him from Greece were put to good service.

At a time when increasingly more Europeans were beginning to imagine a Greece independent from the Ottoman Empire and as part of Europe, Byron believed that an integral step to forging a more intimate cross-cultural involvement between Modern Greeks and Britons

${ }^{26}$ See Byron's Letters and Journals, Vol. 2: Famous in my Time. Ed. Leslie Marchand. 
was through Britons' knowledge of Modern Greek language and literature. ${ }^{27}$ Byron's discussion of Romaic language and literature in "Note III" and the "Appendix" reveals that the 23 year old poet was, unlike most of his contemporaries (including the Edinburgh Review writer to whom he responds), aware of a non-classical Greek literary culture which evidenced Greek peoples' broader cultural and intellectual progress and signaled that Greece could indeed one day become independent. Even if the image of a Hellenic Greece ultimately came to dominate the European consciousness in the early nineteenth century, both inside and outside of Greece, Byron's "Note III" and "Appendix" demonstrate that the poet nonetheless had his finger on the pulse of the times and, in particular, a good understanding of Romaic culture as constitutive of Modern Greek national identity. Indeed, Romaic culture, effectively silenced during and after the Greek War of Independence, would once again find a voice in the latter part of the nineteenth century through supporters of the Demotic movement who insisted that vernacular Greek culture was an integral part of Modern Greece, despite a forced Hellenization that obfuscated this fact. A closer look at Byron's commitment to Romaic culture, then, allows us not only to understand more completely the poet's unique lifetime attachment to Greece but also the intricacies and dynamics of nineteenth-century Greek nationalism and, more generally, British Romantic Hellenism. After all, it is in the period between Byron's first and second trips to Greece that significant changes to Greek national identity occurred, changes that altered the way nineteenth-century Britons regarded the Greeks and which have influenced the way we interpret British Romantic Hellenism even today.

\footnotetext{
${ }^{27}$ In "Beware of (Phil)Hellenes Bringing Gifts: Lord Byron and Greece," Maria Koundoura echoes the somewhat common critical sentiment that Byron ignored actual Greeks when he was in Greece. Although this idea has some truth to it, I think there is sufficient evidence of Byron's acquaintanceships with Greeks in 1809-11, including Andreas Londos (later hero of the Greek revolution), Ioannis Marmarotouris (his Greek tutor), Athanasios Psalidas, Nicolo Giraud (Byron's French-Greek lover), Demetrios Zograffo (whom Byron brought to England with him to be his servant), and the Macri family (from whom Byron and Hobhouse rented lodgings; Byron wrote "Maid of Athens" for Teresa Macri). Byron also writes to Hobhouse on 23 August 1810 to tell him that he has six associates in the Capuchin Convent: "three are Catholics and three are Greeks" (BLJ II.12).
} 


\section{Chapter Three}

\section{There's No Place Like Homeland: Victimized Greek Women, The Greek War of Independence, and the Limits of European Philhellenism}

\section{Introduction}

In February 1821, the Phanariot-Greek Alexander Ypsilantis delivered a call to arms in Jassy, Moldavia, announcing that the Greeks would go to war against the Ottoman Empire in a public declaration that officially initiated the Greek War of Independence. As news of Greece's revolution reached Europe in the months following Ypsilantis's call to insurrection (with an English translation by Percy Bysshe Shelley appearing in The Morning Chronicle on 13 April 1821), the continent's philhellenes rejoiced that Greece would take its place as part of Europe. ${ }^{1}$ The predominantly conservative governments of Europe's great powers, including Britain, however, remained unmoved by Greece's desire for independence. For them, post-Napoleonic Europe required political stability, which included stifling any and all national uprisings. In Britain, "[a]rrayed against the philhellenes were the mightiest establishment forces in British politics: towering Tory figures like the Duke of Wellington and Lord Castlereagh, as well as the conservative King George IV himself, who all wanted the Ottomans to crush the Greeks" (Bass 48). In fact, foreign secretary Lord Castlereagh was one of the main architects of a conservative, reactionary post-Napoleonic Europe and "his secretive and often reactionary foreign policy, cozily aligning Britain with the despotic empires of the Holy Alliance, made him a lightning rod for liberal and radical hatred at home" (Bass 59). For Lord Castlereagh, Greece's insurrection was an affront not only to Britain's political ally, the Ottoman Empire, but also to European stability more generally. "While Castlereagh was at the head of affairs," writes William St. Clair,

\footnotetext{
${ }^{1}$ For more on the Greek War of Independence as a war with internationalist scope that would bring Greece into a broader European sphere of influence, see chapter 5 of William St. Clair's That Greece Might Still Be Free, aptly entitled "The Cause of Greece, the Cause of Europe."
} 
"no open support for rebels could be tolerable to the Government and most moderates, even if sympathetic to the Greek cause, were not inclined to oppose the official policy" (139).

After George Canning became foreign secretary (and later prime minister in 1827) following Castlereagh's suicide in September 1822, the British government adopted a more liberal policy toward the Greek rebels: Canning declared Britain neutral in Ottoman-Greek warfare and then, in March 1823, "formally recognized the Greek revolutionaries as belligerents, giving them the protections of the laws and customs of war" (Bass 114). Most significantly, it was a combined British, Russian, and French fleet that scored a decisive victory over the Ottoman Empire's navy in Navarino (Pylos) on 20 October 1827, which opened up the path for Greek independence from the Ottoman Empire (Smiley 43). However, for British philhellenes, the wait from 1821 (when the Greeks declared their intention to be a free country) to 1827 (when Europe finally intervened militarily on behalf of the Greeks) was a long one which gave British supporters of the Greeks the impression that their government was apathetic toward the Greek cause. To be sure, though Canning did much to support the Greeks, his negotiations with his European allies who were opposed to Greek independence—most anti-Greek of them all being the ultraconservative Austria under the leadership of Prince Klemens von Metternich, who allied his country with the Ottoman Empire-were slow-going as the foreign secretary had to ensure that he did not jeopardize his country's foreign relations while helping Greece. As St. Clair summarizes aptly: "It was largely through Canning's foresight, energy, and diplomatic skill, that an outcome to the Greek Revolution satisfactory to the powers was eventually arrived at. But there was never any question but that his chief concern was the advancement of British interests" (139-40). 
Despite the British government's official position (pro-Ottoman with Castlereagh, then neutral with Canning) in the early years of the war, the Greeks were not without their vocal supporters in Britain, foremost amongst them being the country's writers. In the next two chapters, I will examine literary works that were produced during the Greek War of Independence and discuss how British authors negotiated their country's interest in the Greek War of Independence with their government's foreign policy concerning the Greek-Ottoman war. In this chapter, I focus on Percy Bysshe Shelley's lyrical drama Hellas (1822), Catherine Grace Godwin's novel Reine Canziani (1825), and Felicia Hemans's narrative poem “The Bride of the Greek Isle" (1825), examining the three writers' employment of the trope of the "captive woman" in order to generate support for the Greek cause. In the next chapter, I discuss how Tertius Kendrick's The Travellers (1825) and Mary Shelley's The Last Man (1826) (re)imagined, in light of the British government's seeming apathy towards the Greeks, a GreekBritish relationship in which Britain would be of greater assistance to the Greek cause. In the first two chapters of my dissertation, I examined how Britons portrayed Modern Greeks as part of the Ottoman world and Europe and considered how their "modern" identity might be shaped and shifted by their further acquaintance with Europe and Britain; chapters three and four both extend and complicate this analysis. That is, while chapters three and four explore Greece being brought even further into a European sphere of influence, they also question the problems involved in doing so. Namely, I suggest British writers during the Greek War of Independence became concerned that Greeks, seen by Westerners as Eastern subjects "foreign" to Europe, and at a clear power disadvantage in their relations with a dominant Western Europe, potentially could be forced to adopt a modern European identity that clashed with their own indigenous ones. It is Greek peoples' lack of personal and political agency, and British writers' attempts to 
rectify the power imbalance between Britain and Greece, that I examine in chapters three and four.

\section{Captive Greek Women and the Limits of British Philhellenism}

On a purely visceral level, the decision by Shelley, Godwin, and Hemans to use captive Greek women to generate support for the Greek War of Independence was a smart one, as the Ottoman Empire's alleged mistreatment of Greek women was seen as one of the major justifications for intervention by countries like Britain in Greek-Ottoman affairs. Indeed, during the Romantic era, European writers produced various works that condemned the East for its mistreatment of women, doing so to celebrate the West for its better conduct toward women and thus to emphasize its cultural superiority over the (orientalized) East. ${ }^{2}$ In general, these narratives focused on women in the Eastern harem. As Gonda Van Steen writes, "[t]he harem women's enslavement to the eastern tyrant's pleasure was a key marker of Oriental tyranny and depravity. Such highly persuasive narrative techniques and widespread Orientalist conventions reinforced the adversarial outlook on West-East interactions" (18). Shelley, Godwin, and Hemans were certainly aware of the discourses surrounding the tyrannical East's injustices toward women and employ the trope of the captive woman in their works so as to generate support for the Greek revolution. However, as I argue in this chapter, the three writers' use of captive Greek women is not merely a ploy or a cheap emotional plea to their British readers to support the Greeks in escaping a tyrannical Ottoman Empire. In fact, I argue that Shelley, Godwin, and Hemans all move beyond the discourse of captive women as victims of a despotic East, and present female captives in their works to ask pressing questions of their fellow Britons about their own positions

\footnotetext{
${ }^{2}$ For more on British Romantic-era receptions of the East, see Interrogating Orientalism: Contextual Approaches and Pedagogical Practices, ed. Diane Long Hoeveler and Jeffrey Cass, Columbus: Ohio State University Press, 2006; and Mohammed Sharafuddin, Islam and Romantic Orientalism: Literary Encounters with the Orient, New York: Tauris, 1994.
} 
vis-à-vis the Greek War of Independence. Importantly, I suggest that all three writers use captive women to challenge both those Britons opposed to or apathetic toward Greek independence and national sovereignty and those who advocate a philhellenism detrimental to the Greeks because it ignores the realities of every day Modern Greek life.

In Hellas, Shelley makes the commonplace alignment between female captivity and the despotic East by featuring a Chorus of Greek Captive Women in a harem, but he also finds European countries responsible for Greece's subjugation as they condone the Ottoman Empire's actions by refusing Greece assistance. For Shelley, Europe's emphasis on political stability meant further subjugation for Greece (and in terms of his poem, the Chorus of Greek Captive Women). As he writes near the end of Hellas: "Victory! Victory! Austria, Russia, England, / And that tame serpent, that poor shadow, France / Cry peace, and that means death when monarchs speak" (967-69). Shelley's poem, though, while certainly a rebuke of the Ottoman Empire and European nations who support it, is also critical of a philhellenism that fails to consider the everyday realities of contemporary Greece. Shelley's critique of an uncritical philhellenism is made most apparent by analyzing Hellas's Chorus of Greek Captive Women who adopt philhellenic rhetoric in celebrating Greece's rebirth, but who eventually realize that the ancient ideal is unattainable in the modern world. By the end of Hellas the captive women come to learn that ancient paganism is discordant with their Christianity and that the myths of the past are rooted in a legacy of violence, leaving them to lament "The world is weary of the past, / O might it die or rest at last" (1100-1).

While Shelley rejected an uncritical philhellenism, he still believed Greece was best served by Western intervention and influences. Godwin, on the other hand, problematized European intervention in Greece. In her novel Reine Canziani, Godwin features a Greek heroine 
(Reine) who is forced to flee her home in Belgrade Forest (in Constantinople) when her father George Canziani is imprisoned after being falsely accused of conspiring against the sultan and her fiancé Constantine is murdered by Ottoman janissaries. Reine endures many hardships after her departure from home, including being stranded at sea by the evil Seid and being gifted by Hussein Pasha to the Albanian Ali Pasha, who wants her to join his harem. The worst mistreatment Reine encounters, however, is not at the hands of the Ottomans, but at those of the Englishman Monthermer, a Lord Byron type who deceives her into living together out of wedlock before impregnating and abandoning her. Godwin cuts a fine line: although she supports Greek liberation and is critical of Ottoman violence toward Greeks, her novel acts as a criticism of British liberals who purported to care about Greek liberty but who acted as salaciously and injuriously as the Easterners whom they demonized.

Finally, Hemans, in contrast to Shelley and Godwin, features in "The Bride of the Greek Isle" a strong-willed Greek woman, Eudora, who refuses to be victimized and oppressed. The poem, which begins as a fairly conventional narrative about a young woman leaving her home to wed, takes a dark turn when Eudora and Ianthe's wedding is invaded by pirates who murder a majority of the wedding party, including Ianthe, and take Eudora captive on their pirate ship. Eudora's imprisonment spurs the young woman's patriotism and her decision to set the ship, and thus herself, ablaze is used to demonstrate the Greek woman's national pride, which is ultimately connected to liberation: "Never might shame on that bright head be, / Her blood was the Greek's, and hath made her free!" (213-14). In featuring a protagonist who decides to self-immolate following her capture by pirates on her wedding day, Hemans emphasizes for her readers the relation between womanhood and patriotism. Eudora's act, however, is not only about a proud Greek woman overcoming her (presumably Ottoman) captors. Rather, I argue that Eudora's 
setting of the ship on fire is a jarring plot turn that forces Hemans's British readers to reflect upon their own readings of the poem (and of Greece) prior to the climatic fire scene. The beginning of "The Bride of the Greek Isle" lulls readers into consuming an idyllic pastoral Greek setting with "citron-flowers" (1), "lyres for the festal hours" (2), and "Maids of bright Scio" (3), a scene which contrasts deeply with the violent latter part of the poem. I argue, then, that Hemans abruptly and unexpectedly changes the tone of her poem - with the arrival of the pirate horde and Eudora's self-immolation — as a call to her fellow citizens to stop romanticizing (and classicizing) Greece and instead to become cognizant of the real life tragedies occurring in the modern country during the Greek War of Independence. Eudora's patriotic act, moreover, confutes conceptions of Greece as passively female in matters of war, forcing readers to reconsider both Greeks' capacity for autonomous national assertion and the link between womanhood and nationhood.

Ultimately, by featuring captive Greek women in their works, Shelley, Godwin, and Hemans use womanhood and femininity as critical lenses through which to question Britain's (and Europe's) humanitarian, democratic, and liberal values, as well as to test the limits of a Greek nationalism constructed, and liberation obtained, through European philhellenism. Greek women in Hellas, Reine Canziani, and "The Bride of the Greek Isle"-as both orientalized Easterners and Hellenized Westerners; victimized others of both Ottomans and Britons; representatives of the Greek nation but also passive observers of its direction and fortunes; oblivious to the dictates of war but imbued with other forms of knowledge (domestic, communal, ritualistic)—place into stark relief the stakes, contradictions, and problems inherent in Europeanizing Greece. Whether Britons ignored Greece's desire for national independence or advocated Hellenizing Greece and making it part of Europe, Shelley's, Godwin's, and Hemans's 
narratives of captive Greek women forced British readers to recognize how their country's own cultural prejudices, political dividedness, and conflicting ideological commitments helped to keep Greece enslaved.

\section{"Riddles of Death Thebes Never Knew": The Chorus of Greek Captive Women in Hellas}

When the Greek War of Independence began in March of 1821, Shelley, true to his revolutionary principles, supported the Greeks in their bid for liberation. Most notably, Shelley penned the dramatic poem Hellas, the proceeds of which went to finance war efforts in Greece. From the poem's Preface, which L. M. Findlay claims “depends on distinctions between savage and civilised, European and Asian, which are disappointingly ethnocentric Enlightenment clichés" (283), Hellas gives the impression of being a propagandistic composition. The Preface deems the Modern Greeks "descendant[s] of those glorious beings whom the imagination almost refuses to figure to itself as belonging to our kind" (447), emphasizes the courage shown by Greeks in the war, and encourages Europeans to support Greek emancipation as it is to the Greeks whom they "owe their civilization" (447). So adamant is Shelley that Europe is indebted to the Greeks that he famously declares, "[w]e are all Greeks. Our laws, our literature, our religion, our arts, have their root in Greece. But for Greece, Rome, the instructor, the conqueror, or the metropolis of our ancestors, would have spread no illumination with her arms, and we might still have been savages and idolaters" (447).

Shelley's decision, too, to model his poem upon Aeschylus's The Persians gives further credence to claims such as Findlay's concerning Hellas's propagandistic imperatives. As Van Steen explains, before the war,

[A]ncient Greek texts provided a means for Greek nationalists and revolutionaries to cultivate their political intent and to keep it relatively hidden—and for the West 
to endorse the Greek patriotic cause. Philological, historical, and nationalist interests could easily be shared among Greeks, philhellenes, and expatriates ... philology and text-based history had long served Greek nationalist politics by generating sympathy and support for the revolutionaries, both domestically and abroad. (31)

Aeschylus's The Persians, with its depiction of the Persians lamenting their empire's devastation by the Greeks at the battles of Marathon and Salamis, was a particularly effective literary vehicle through which nineteenth-century supporters of Greek liberation could champion the Greek War of Independence. Indeed, in 1820 a group of Greek revolutionaries secretly performed Aeschylus's play in Constantinople in order to encourage Modern Greeks to rebel against the Ottoman Empire. Of the production Van Steen writes: “[r]eplaying the Persians as a function of modern Greek history lent a new performative dimension to the paean, glorifying revolutionary violence as a purifying and empowering force" (123).

Moving beyond Hellas's Preface, though, the poem proper is, surprisingly, not unabashedly philhellenic. In fact, Hellas reveals atrocities committed not only by Ottomans, but also by Greeks, and predicts that the Greeks will lose to Ottoman forces with the assistance of Britain, the "Queen / Of Ocean" (303-4). One reason Shelley was reticent about celebrating Greek emancipation in Hellas was that, while he was writing his poem (from August to October of 1821), the war had barely begun, therefore making it impossible to determine who would be victorious. As such, Shelley's ability to discuss the progress of the war was necessarily limited, and he even asks for "the forgiveness of my readers for the display of newspaper erudition to which I have been reduced" (Preface 447). More importantly, though, I suggest that Shelley refuses to unequivocally extol the Greeks because his main objective is less to celebrate Greek 
victory and more so to scrutinize the consequences of European philhellenism, which he does through his portrayal of the Chorus of Greek Captive Women.

As I discussed in Chapter 2, the early nineteenth century witnessed the Hellenization of the Greeks; that is, Greeks in greater numbers began to identify themselves with their ancient ancestors, an identification encouraged by both European philhellenes and diasporic Greeks, and one that intensified during the Greek War of Independence. As St. Clair argues:

By the time of the Greek Revolution in 1821 the educated public in Europe had been deeply immersed in three attractive ideas - that Ancient Greece had been a paradise inhabited by supermen; that the Modern Greeks were the true descendants of the Ancient Greeks; and that a war against the Turks could somehow 'regenerate' the Modern Greeks and restore the former glories. (19) In Hellas, Shelley critiques a philhellenism that, in seeking to liberate the Modern Greeks by Hellenizing them, ignores the realities of contemporary Greeks' cultural identity and sociopolitical situation and provokes cross-cultural violence for the sake of nation-building. As Michael Herzfeld contends,

The 'liberation' of Greece from the Turkish 'yoke' was effected in such a way as to leave the newly constituted country heavily dependent on its ability to present as indigenous an ancient culture that most of its inhabitants experienced as foreign and preternaturally strange, while an entrenched and Western-oriented elite continued the work of cultural refashioning from within as the best means of maintaining its own, foreign-supported authority. (13)

Shelley did not deny Ancient Greece's relevance in the context of the Greek War. Indeed, one of the reasons he dedicated Hellas to Prince Alexander Mavrokordatos was because, as Stephen 
Minta writes, the Greek statesmen understood "[i]f Greek independence could only be won in the end with European acquiescence ... this meant that an independent Greece had to look like a plausible continuation of the classical past" (131). ${ }^{3}$ Shelley, then, acknowledged the importance of Mavrokordatos's objective "to offer a vision of a future Greece that was in line with the fantasies of the outside world" (Minta 131), but also emphasizes in Hellas the need for a more thorough engagement with Ancient Greek culture so that it does not become mere pretence for ethnic conflict. As Jonathan Sachs contends, "Shelley's conception of the past replaces the assumption of direct, transparent relevance with a more nuanced vision in which antiquity continues to be relevant for the present, but only as mediated through an understanding of the complex historical process by which the legacy of the past is transmitted to the present" (15960). By featuring a Chorus that attempts — but fails — to employ the discourses of philhellenism in securing its liberation, Shelley looks to the Greeks' bid for independence to force his readers to reflect more carefully upon contemporary Greece - culturally, politically, and historically.

That is, Shelley challenges British philhellenes—including himself—-to consider in greater detail Greece's contemporary identity, to become better familiarized with the atrocities of GrecoOttoman warfare, and to engage more effectively with ancient history so that it has the ability to transform positively the present and future.

Shelley's decision to use Hellas to interrogate philhellenism's cultural, political, and historical prerogatives, I suggest, prompted his choice to model Aeschylus's The Persians for his own drama. True, as I have noted, The Persians was in the Greek revolutionary period performed

\footnotetext{
${ }^{3}$ In The Nation and Its Ruins: Antiquity, Archaeology, and National Imagination in Greece (Oxford: Oxford University Press, 2007), Yannis Hamilakis argues that an independent Greece first and foremost tried to replicate the ancient past through its architecture and ruins. "As the new imagined community of the nation was establishing itself and as it was attempting to create its own nation-state," writes Hamilakis, "antiquities, the material signifiers of continuity between classical Greece and the new nation (soon to become state), became extremely prominent ... if nationalism is a topographic and iconographic project, then ancient buildings and artefacts are essential in defining that territory, in providing its landmarks" (78-79).
} 
and read to generate support for Greek liberation. Interpretations of The Persians which focus only on the play's celebration of Greek victory over Xerxes and his army, however, ignore Aeschylus's various attempts to humanize, and sympathize with, the Persians. For example, the Chorus of Persian Elders early in the play informs the audience that Persian women fill Xerxes's palace with "frenzied groans" (124) and "[b]eating of breast and head" (126) and that each Persian wife waiting for her husband to return from war "[w]eeps out her lonely life" (139). Later in the play, a messenger informs Xerxes's mother Atossa that the Greeks lured the Persians into the strait of Salamis and then systematically slaughtered them in a passage that casts doubt on Greek heroism in war:

The Hellenes seized fragments of wrecks and broken oars And hacked and stabbed at our men swimming in the sea As fishermen kill tunnies or some netted haul.

The whole sea was one din of shrieks and dying groans, Till night and darkness hid the scene. If I should speak For ten days and ten nights, I could not tell you all That day's agony. But know this: never before In one day died so vast a company of men. (425-32)

Far from celebrating Greek heroics, this passage is meant to elicit compassion for the Persians and force an Athenian audience to recognize that even Greeks are capable of barbarity, a theme that Shelley elaborates upon in Hellas. As the messenger describes them, the Greeks do not behave bravely but cruelly and savagely, seizing pieces of broken fleet to "hack" and "stab" the 
Persians to death "as fishermen kill tunnies or some netted haul," a simile Aeschylus uses to further devalue Greek soldiers' actions. ${ }^{4}$

While Aeschylus's play certainly celebrates Athenian politeia —and especially the democracy that makes Greek free men - it does not endorse a simplistic West-East binary or promote ethnic antagonism between Greeks and Persians, even if some Greeks and philhellenes read the play this way during the war for independence. Instead, Aeschylus asks his viewers to reflect upon the brutality of, and destruction caused by, war. It is for these reasons, I argue, Shelley decided to adopt The Persians as a model for Hellas. In fact, I propose that Shelley's rejection of interpretations of The Persians which viewed the play as an endorsement of EastWest conflict is made most apparent by his conversion of Aeschylus's originally Persian male chorus into a Greek female one. Writing about an 1817 reading of Euripides's Hecuba at a school in Kydonies, Van Steen argues that the Greek student production focused on portraying Greek male heroism rather than sympathizing or empathizing with the suffering of Trojan women in the war because the latter "would have jeopardized the Greeks' desire to cast off Orientalist biases of effeminacy and weakness. Equating the Trojan women with the Ottoman opponents, on the other hand, allowed the Greek students to indulge in similar Orientalist prejudices about the enemy" (142). By ignoring the fate of foreign captive women in ancient drama, Modern Greeks were able to emphasize East-West distinctions and portray themselves as Westerners.

\footnotetext{
${ }^{4}$ Aeschylus's intention to have his Greek audience sympathize with the Persians is also evident at a linguistic level. For example, Mary Ebbott claims that "Greek ritual and speech forms are integrated into the Persian milieu ... Persians give voice to a very Greek understanding of events" (373). Casey Dué, referring specifically to Xerxes's and the Chorus's laments at the end of the play, comments that they "are intensely Greek in their content and emotional force, thereby transcending distinctions between Greek and barbarian and in fact merging the two in the emotional experience of the audience" (57). See Mary Ebbott, "Marginal Figures," A Companion to Greek Tragedy, ed. Justina Gregory, Oxford: Blackwell Publishing, 2005: 366-76; Casey Dué, The Captive Woman's Lament in Greek Tragedy, Texas: University of Texas Press, 2006.
} 
Shelley, on the other hand, highlights the relationship between captive women and Greeks in a move that troubles Greek attempts to make the victimized an (Eastern) "other" and which underscores Greece's liminal status in relation to both Europe (the West) and the Ottoman Empire (the East). Shelley's Chorus of Greek Captive Women's failure to establish a national topos (or homeland) by identifying with westernized conceptions of Ancient Greece emphasizes the precarious cultural and geopolitical situation Greeks found themselves in at the beginning of the Greek war. By examining the tensions inherent in Greece's complicated cultural and geopolitical positions, Shelley dismisses an Orientalist philhellenism that sought to free Greece by simply othering the East and westernizing the Modern Greeks. This argument, perhaps, does not sit comfortably with Hellas's Preface. However, I suggest that, despite Shelley's clear cultural biases in the Preface, the poet's portrayal in the play of the Chorus struggling to identify with Western European conceptions of the Hellenic that buttress Christian-Muslim warfare accords well with his desire to avoid cultural antagonisms and conflicts, a desire expressed by the Chorus at the end of Hellas.

Finally, and perhaps most importantly, I propose that Shelley, by making his captive chorus Greek women, indicates who his main audience for Hellas is and thus, who he is asking to sympathize with the chorus as "other." If Shelley's chorus was Ottoman men, his drama, like The Persians, would be a play about the precariousness of imperial power, a theme which acted as a warning to Athenians that "the very divine and daimonic forces that brought down the Persian empire might just as easily strike down the Athenians should they too seek domination" (Erkelenz 319). With an Ottoman chorus, Hellas's implicit audience would be Greek, as was Aeschylus's. By featuring a female Greek captive chorus, though, Shelley's play is instead directed at a broader audience (likely English-reading and British, but perhaps European) who is 
asked to sympathize with the suffering of the "other"-not Persians or Ottomans, but Modern Greeks. ${ }^{5}$ In fact, the Chorus's celebration of national independence (and universal liberation) rather than mourning of imperial decline signals Shelley's desire to engage all audiences interested in Modern Greece's attempts to forge a national and cultural character. ${ }^{6}$ Shelley's Chorus, as Greek women from a country on the margins of East and West who have trouble mediating the ancient past, makes tangible for Hellas's readers Greece's precarious position visà-vis Europe and the problems inherent in trying to liberate Greece by Hellenizing the country's population.

Hellas is divided into seven sections which alternate between the Chorus's (four) lyrical odes and the Ottoman characters' (three) dialogues. Although the Chorus does not converse with any of the other characters in the drama, each of its lyrics (except the first, which initiates the play) responds to the dialogue scenes between the Ottoman characters. As lyricists, Shelley's Chorus is similar to choruses in ancient drama who also perform lyrics as one of their main functions. "The lyric," comments Luigi Battezzato, "was a formalized literary genre in archaic and classical Greece, practiced by Pindar and Simonedes among others, and was at times performed as a civic ritual" (160). The fact that Shelley's captive women practice an ancient ritualistic custom demonstrates their vital presence in Hellas as representatives of Ancient Greek tradition. Through lyric, Shelley's Chorus engages with its Hellenic past and maintains a powerful role in the poet's drama. As Mark Griffith writes, "[t]he lyric utterances of a chorus ... often carry a special authority of their own, by reason of the traditional function of choruses as

\footnotetext{
${ }^{5}$ This argument does not discount the fact that Shelley might also have a Greek audience in mind; indeed, by dedicating the poem to Prince Alexander Mavrokordatos, Shelley points to his own relationship with an Englishspeaking, European-educated Greek man. I think it is plausible to argue that Hellas, even if it was published in London, also addresses Greeks and challenges them to consider their relationship with the West and Europe by identifying them with the victimized "other," a role that was in Ancient Greek drama usually reserved for foreigners. ${ }^{6}$ As Shelley himself explains, "the glorious contest now waging in Greece being yet suspended forbids a catastrophe parallel to the return of Xerxes and the desolation of the Persians" (Preface 446).
} 
performers of communal wisdom and memoralization, even though in any particular play the chorus members, qua characters, might be relatively ignorant, low-class, and unreliable" (347). By employing the lyric form, Hellas's harem women, despite being captives, transcend temporarily their status as slaves and celebrate Greek history in passages that demonstrate their vast ancestral knowledge.

Indeed, with Sultan Mahmud troubled by recent uprisings throughout Greece and suffering through an agitated sleep, the Chorus detects an opportunity for liberation and begins its first lyrical passage by providing a mytho-historical account of Liberty, naming Thermopylae and Marathon as the first two locations through which Freedom travelled following its "birth." The captive women's allusion to the historical moment when Greeks liberated themselves from the Persian Empire (and to Aeschylus's The Persians) allows them to distance the Modern Greeks culturally and ideologically from their "Eastern" Ottoman oppressors; in fact, the women claim that "When .. / Tyrants sleep, let Freedom wake" (29-30). ${ }^{7}$ The women's allusion to The Persians allows them to envision, as did nineteenth-century Greek revolutionaries who adapted Aeschylus's play, freedom for both themselves and their country. Also, by creating this Greek/Ottoman divide, the Chorus is able to start to forge a modern national identity for the Greeks; indeed, as Artemis Leontis argues, "homeland requires that one narrate a past, claim a

\footnotetext{
${ }^{7}$ Shelley's decision to name these two city-states as the first to receive Freedom signals immediately his intertextual relationship with Aeschylus and thus indicates his belief that the Greeks' battles against the Persians at these two city-states were paramount events in human history. In fact, Greece's resistance of the Persians was followed by a period that many, Shelley included, considered the most glorious period in human history. See especially Shelley's "On the Literature, the Arts, and the Manners of the Athenians" in which he writes: "The period which intervened between the birth of Pericles and the death of Aristotle, is undoubtedly, whether considered in itself, or with reference to the effects which it has produced upon the subsequent destinies of civilized man, the most memorable in the history of the world" (39). See Shelley: Prose Works Vol. 2, ed. Richard Herne Shepherd, London: Chatto \& Windus, 1897: 39-47. Moreover, so significant was Marathon to the Ancient Greeks that Aeschylus's epitaph commemorates his role in Greeks' victory over the Persians at Marathon, but does not mention that he was a playwright. For more on Aeschylus's epitaph, see Chapter 14 (“Aeschylus's Epitaph") of Alan H. Sommerstein, The Tangled Ways of Zeus: And Other Studies In and Around Greek Tragedy, Oxford: Oxford University Press, 2010.
} 
present, and prophesy a future" (3). As the dominant philhellenic rhetoric suggested, what the Ancient Greeks once achieved once, the Modern Greeks could accomplish yet again.

The Chorus's celebration of Freedom becomes ominous, though, when the women narrate their country's relationship with Liberty in Christianized terms. Separated into two semichoruses (Semichorus 1 and Semichorus 2), the women narrate for a second time Freedom's "birth" and "death." However, as opposed to the opening of their paean, where the Chorus's description of Freedom's origins was mythological and classical in orientation, the women now situate the relationship between Greece and Freedom in a Christian framework; specifically, Freedom is described as a Christ-like figure and Greece a devout disciple. The women detail Greece bringing gifts to Freedom's “cradle” (95), crying on Freedom's "shroud” (97) upon its death, and appearing at Freedom's "resurrection" (100). By using Biblical images and associating Freedom with Christ, the Chorus effectively connects Modern (and even Ancient) Greece's destiny to Christianity. Further, the Chorus's decision to yoke Greece, Freedom, and Christianity demonstrates how the captive women's ideas correspond with the beliefs of the majority of Greeks who thought "it was primarily their religion that distinguished them from the Turks" (St. Clair 8) and who used religion as a justification for liberation. As Maria-Fani Tsigakou relates, "[t]he Greek struggle ... became the sacred war of Christians against the infidels. Indeed, it recalled the Crusades in its juxtaposition between the Cross and the Crescent" (47).

Shelley did not support a religious war, however, and it becomes clear that the Chorus's Christianized conception of Greek freedom will not bring about their desired liberation. In fact, the apocalyptic imagery associated with the conclusion of the opening lyric foreshadows the misery the Chorus's Christian formulation of Freedom brings to the members later in the play: 


\title{
Semichorus 1
}

If Heaven should resume thee,

To Heaven shall her spirit ascend;

\section{Semichorus 2}

If Hell should entomb thee,

To Hell shall her high hearts bend

\author{
Semichorus \\ If Annihilation- \\ Semichorus 2 \\ Dust let her glories be!
}

And a name and a nation

Be forgotten, Freedom, with thee! (102-9)

Here, we witness a Chorus, perhaps reflective of a Greek populace, which is of two minds. Particularly problematic is the Chorus's idea that Freedom is subject to religion, as observed in the lines, "If Heaven should resume thee" (102; italics mine) and "If Hell should entomb thee" (104; italics mine). In the Chorus's formulation, Freedom is no longer an independent entity but instead dictated by a Christianity that decides if Greece will "ascend" or "bend," yet another binary that Shelley inserts into this passage that is composed of many incongruent rhyming couplets (including "gladness" [94] and "sadness" [96]; "strew" [97] and "bedew" [99]; and "Annihilation" [106] and "nation" [108]), which emphasize how divided the Chorus is. "Dust let her glories be!", too, gives readers an early indication of the Chorus's desire later in the play for liberation from a burdensome Greek past.

Although the women's first lyric demonstrates their vital role as "performers of communal wisdom and memoralization," it also reveals their troubling interpretation of the ancient past and how their position from within the seraglio limits their ability to understand the 
circumstances of the war. Stephen Cheeke clarifies: "Choral lyrics 'sing' from restraining dramatic contexts, contexts of historical tension and moments which they cannot transcend through a lyrical mode but rather must embody and express within their formal structures" (205). Cheeke's assessment helps readers understand, I think, why the choral lyrics describe a return to an idealistic Hellenic past by adopting Christian language: because the Greek women are Christians who, from the limited perspective of the seraglio, hear conversations between Ottoman officials indicating that their countrymen are embroiled in Christian-Muslim warfare (conversations which take place between each of their lyrics). ${ }^{8}$ The women can only understand the revolution, then, as a religious war, even if they are privy to Hellenic knowledge through their role as lyricists. Nevertheless, their juxtaposition of Hellenism and Christianity troublingly aligns the Ancient Greek past with a violent contemporary religious war in ways that threaten to poison the discourse of philhellenism and, thus, to put into jeopardy the Greek cause.

Shelley associates Christianity and Paganism not to demonstrate the affinity between the two religious frameworks (as the Chorus attempts to do) but, rather, to illustrate how the former is irreconcilable with the latter. ${ }^{9}$ This, in turn, allows the poet to reveal the precariousness of Greeks' and European philhellenes' adoption of Hellenism to incite religious and ethnic antagonisms. In a sense, the Chorus co-opts the discourse of Hellenism to promote religious war, as did various Greek revolutionaries, including Alexander Ypsilantis, whose call-to-arms Shelley had translated. To be sure, though most Greeks welcomed the support for the revolution generated by Europe's Hellenic conception of Modern Greece, some had not embraced

\footnotetext{
${ }^{8}$ In fact, Shelley adds a note to his second lyric explaining that his personal opinions concerning Christianity are not compatible with those of the Chorus: "The popular notions of Christianity are represented in this chorus as true in their relation to the worship they superseded, and that which in all probability they will supersede, without considering their merits in a relation more universal" (584). Shelley emphasizes that the Chorus's view of Christianity is that of worshippers who believe in the religion and is, therefore, a biased assessment of Christianity. ${ }^{9}$ Jennifer Wallace argues that Shelley drew upon Greek paganism in order to challenge "the repressive measures of the government and the narrowness of Christian morality promoted by the politically powerful Church of England"

(102). See Shelley and Greece: Rethinking Romantic Hellenism, New York: St. Martin's Press, 1997.
} 
philhellenic notions of a Hellenized Greece and instead preferred a newly-established Christian state on a Byzantine model at best, and, at worst, an "Eastern theocracy in which the Moslems had simply been replaced by Christians" (St. Clair 95). For Shelley, the prospect of a theocratic Modern Greece would have indicated a failed revolution. In the Chorus's second lyric, the women undergo a dramatic change, from idealistic to skeptical, that reflects how untenable Shelley believes to be the Chorus's association between the Hellenic world and Christianity.

The irony of the Chorus's second lyric — a variation on Milton's On the Morning of Christ's Nativity in which the elder poet lauds Christianity's emergence (Cheeke 209)—is that, in celebrating Christianity's triumphant return to Greece, the women end up revealing that the religion was responsible for the decline of paganism, and by extension, the Hellenic world:

Swift as the radiant shapes of sleep...

So fleet, so faint, so fair,

The Powers of earth and air

Fled from the folding star of Bethlehem:

Apollo, Pan, and Love,

And even Olympian Jove

Grew weak, for killing Truth had glared on them;

Our hills and seas and streams

Dispeopled of their dreams,

Their waters turned to blood, their dew to tears,

Wailed for the golden years. $(225 ; 229-38)$

Describing the Pagan gods' actions as "so fleet, so faint, so fair" and rhyming "fair" with "air," the Chorus portrays these deities as more peaceful and connected to the natural world than is the 
Christian God that followed their reign. Upon seeing the "star of Bethlehem" (revealing the birth of Christ), all the Greek gods_-"even Olympian Jove," the most powerful pagan deity— - grew weak," implying that they became progressively powerless. Christianity's "killing Truth" did not only affect the pagan gods, however, but also Ancient Greek citizens. Identifying themselves with the Ancient Greeks (as indicated by their use of the pronoun "our") the captives declare that Christianity "dispeopled" Greece and turned all the country's natural elements—-waters and dews - into pain. The Chorus for the first time in the play identifies the downfall of Hellenism with Christianity and becomes skeptical about the religion's prominence in Greece, a skepticism that turns into disillusionment after the Chorus learns about the religious warfare that has threatened the Greek cause for liberty when listening to Sultan Mahmud's messengers and advisors report to the sultan about the war. Indeed, by placing the scene between the sultan and his men immediately after the Chorus has inadvertently revealed that Christianity was responsible for the end of the "golden years," Shelley forces his readers to link the advent of Christianity with contemporary religious and ethnic antagonisms. As a result, Shelley implicates the Modern Greeks themselves in Hellenism's death (as they continue to engage in a religious war that guarantees the "golden years" will never return) and demonstrates for European philhellenes their misapplication of the ancient past on a contemporary war.

The religious antagonism inciting the Greek War of Independence becomes ostensible for the Chorus when they overhear conversations between Sultan Mahmud and his main advisor, Hassan (immediately following their second lyric). Hassan reassures the concerned sultan about the war with Greece by telling him,

Samos is drunk with blood; - the Greek has paid.

Brief victory with swift loss and despair. 
The false Moldavian serfs fled fast and far, When the fierce shout of 'Allah-illa-Allah!'

Rose like the war-cry of the northern wind. (287-91)

Here, Hassan explains that the initially successful Greeks are now losing to the Ottomans, Samos being "drunk with blood" and the Moldavians, who initiated the war of independence, retreating at the sound of the Ottoman war cry. Indeed, the Ottomans are the aggressors in this passage, but Shelley ensures that his play does not become Christian propaganda by having Hassan explain that the Greeks too commit atrocities.

In a passage that recalls The Persians, Hassan narrates a Greek naval victory over the Ottomans just as Xerxes's messengers did to Atossa and the Persian Chorus about the GrecoPersian War. Like Aeschylus, Shelley focuses on the atrocities of war rather than the impressiveness of Greek victory. Hassan describes "the shrieks of our companions" (512), accentuates how many lives have been lost— "Nine thousand perished" (514)—and explains that vultures and dogfish have gone "hastening to the feast" (521), feeding upon the bodies of the dead Ottomans. Just like the Persians, the Ottomans have suffered a stunning defeat. However, whereas the Greeks in The Persians were motivated by defending themselves from invasion (and a form of cultural imperialism), the Greeks' attack in Hellas is motivated by religious and ethnic hatred. Shelley emphasizes the religious aspect of the war in Hassan's description of how the Greek ships surrounded those of the Ottomans: "The abhorrèd cross glimmered behind, before, / Among us; and that fatal sign / Dried with its beams the strength in Moslem hearts" (501-3). By metonymically equating Greeks and the Christian cross, Shelley demonstrates how religion has become the main motivation for the Greek revolution and is the very means by which victory is secured by Greeks in the episode recounted by Hassan. 
After hearing Hassan's account, the Chorus realizes that re-establishing the glorious past through Christianity is inconceivable, leading to a crisis of identity for the women. According to Filiz Turhan, “one of the reasons for Shelley's failure to maintain the balance that he seeks in Hellas is the tenuousness of the crucial first dichotomy upon which all the others are based: Greek/Turk (and by implication, liberty/despotism; eternal/ mutable). For when the rigid lines between Same and Other begin to blur, the other dichotomies also falter" (94). In their third and fourth lyrics, the captive women attempt to disassociate themselves from the current war in Greece and establish a new engagement with the Hellenic past apart from Christianity and Christian-Muslim warfare. In order to escape the realities of the war, the captive women conceive of Greece as a transcendental realm to which they can flee, claiming that "Greece and her foundations are / Built below the tide of war, / Based on the crystalline sea / Of thought and its eternity" (696-99). According to the Chorus, Ancient Greek society based its institutions upon an ideology that gave prominence to "thought" over "war" and it is to this idealized topos that the women wish to escape in order to reconceptualize Greek national identity. Indeed, such "[t]opographies are substantive markers of a homeland," Leontis argues, as "they seem to affix culture to place" (2). The transcendental Greece the women imagine is not simple wish-fantasy, but a way through which they can imagine possibilities that are otherwise inconceivable, including a Greece liberated by means other than religious warfare. Having narrated a transcendental Hellenic topos that allows them to imagine a liberated Greece, the women retreat from their earlier religious discourse connected to Greek-Ottoman warfare and instead propose exchanging "Love for hate and tears for blood" (738) to conclude their third lyric.

Shelley integrates the Chorus's utopian third lyric into Hellas to allow readers to glimpse temporarily a world exempted from power struggles and religious hatred, but not to disassociate 
the poem from the historical realities of $1821 .{ }^{10}$ In fact, the Chorus is unable to maintain its idealistic conception of Ancient Greece, as the women after their third lyric inadvertently reveal that the Hellenic past too was founded upon a history of violence. The Chorus's fourth lyric, I suggest, reveals that even though the women have divorced Hellenism from Christianity, they still do not understand how to mediate the ancient past in a way that will benefit Greece's future. As such, this final lyric acts a warning to Hellas's philhellene readers about misappropriating Hellenism and tying it to a specific political agenda without first understanding the implications of invoking the past. In fact, by demonstrating how the Hellenic past too has its own legacy of violence, Shelley makes explicit the connection between a European philhellenism which looks to draw from that past to establish a Modern Greek state and nationalist violence. If the Chorus's failed coupling of Christianity and Hellenism in their first and second lyrics could be read as a direct judgment of the Orthodox Greeks, Shelley's fourth lyric presents a broader critique of the misuses of the Hellenic past which implicates not only the Greeks but philhellenes who advocated for a Hellenic Modern Greece. Even if philhellenes disavowed the religious conflict between Greeks and Ottomans, Hellas nonetheless criticizes them for introducing Hellenic discourse to the revolution and for thus implicating the ancient past into a contemporary history of violence, intentionally or not.

In their final lyric, the Greek captives begin by celebrating their new transcendental engagement with the Hellenic past and discuss this ideal locale as one in which "Heaven smiles, and faiths and empires gleam, / Like wrecks of a dissolving dream" (1064-65). Heaven, faiths, and empires all become for the Chorus a "dissolving dream," safely aestheticized as products of

\footnotetext{
${ }^{10}$ As Mark Kipperman argues of Hellas's ending: "If Shelley demands utopia emerge within historical struggles, he also insists on annihilating that history whose implicit goal, especially in the West's chiliastic theology, is the triumph and revenge of the good ... Shelley's utopianism strives to awaken us into a world transformed by a dream of love, not a fantasy of power" (167-68). See Mark Kipperman, "History and Ideality: The Politics of Shelley's Hellas," Studies in Romanticism 30.2 (1991): 147-68.
} 
the bygone past. By describing religion and empire in this way, the women seek to disconnect themselves from their previous association with Christianity and instead engage with Ancient Hellas by bypassing religion altogether. However, the Chorus's choice of myths through which they attempt to create this new Hellas is sorely misguided:

A loftier Argo cleaves the main,

Fraught with a later prize;

Another Orpheus sings again, And loves, and weeps, and dies.

A new Ulysses leaves once more

Calypso for his native shore.

O, write no more the tale of Troy,

If earth Death's scroll must be!

Nor mix with Laian rage the joy

Which dawns upon the free:

Although a subtler Sphinx renew

Riddles of death Thebes never knew. (1072-83)

The Chorus believes that the way to resurrect the Ancient Greek past and make it accessible to the present is by simply recalling ancient myths and trying to "relive" them. However, this is exactly the kind of engagement with Greece's past that Shelley discourages because it ignorantly exalts Ancient Greece without recognizing the less idealistic components of this society. Stephen Cheeke argues that the end of Hellas is Shelley's acknowledgment that the

Elements of strife and bloodshed belong to the myths that have shaped ancient Hellas as they do to the events that determine the fate of modern Greece. It is 
therefore a partial withdrawal from the very notion of invoking myth in this way

... it signals that a paean to Greece relying on a simple roll-call of Hellenic

motifs is insufficient. (215)

The Chorus attempts to evoke Ancient Greece in order to escape the present, but this

ultimately proves impossible because, as the women quickly realize, the Greek past itself has its own violent legacy. Shelley's proposition that Ancient Greek culture cannot wondrously create new circumstances for these women and change the conditions under which they remain enslaved would have been especially appropriate for those Greeks and European Philhellenes who idealized Ancient Greece, and promoted Modern Greece's adoption of the Classics, without considering the less flattering aspects of this culture. By demonstrating that the myths the Chorus chooses have more damaging implications than the women initially realize, Shelley reveals that a mere "borrowing" from the ancient past is as inauthentic a way to make the past "present" as was the Chorus's initial Christian conception of Hellenism. ${ }^{11}$

The fact that the women initially identify these myths with "a brighter Hellas" (1066) in which they are no longer captives reveals the particularly limited options women encounter in the Greek war, as the Hellenic myths to which they allude all have terrible consequences for their own sex. ${ }^{12}$ If, as Demetra Tzanaki argues, Greek women had to employ "alternative sources of knowledge, symbols and experience ... to overcome social, behavioural and political obstacles

\footnotetext{
${ }^{11}$ The allusion to "a loftier Argo" is to Jason and the Argonauts who brought the Golden Fleece from Colchis; however, with them they also brought a "later prize," Medea, who, abandoned by her husband for Creon's daughter Glauce, kills her children and flees to Athens (in Euripides's version of the myth). Orpheus's story is equally disheartening: travelling to the Underworld to save his lover Eurydice, Orpheus succeeds in convincing Hades to release her from the Underworld when he stirs the god with his musical abilities; however, Orpheus fails to reclaim his wife from the Underworld when, departing, he looks back to the Underworld against Hades's orders. Finally, although Ulysses's (Odysseus's) departure from Calypso is a seemingly positive event, it is followed by his ruthless killing of Penelope's suitors and twelve housemaids at the end of Homer's The Odyssey. For more on these and other Greek myths, see Robert Graves, The Greek Myths: Complete Edition, London: Penguin, 1992.

${ }^{12}$ Shelley was aware of the misogyny present in Ancient Greek society and he outlines women's inferior status (albeit problematically, blaming it on Ancient Greek homosexuality) in "Essay on the Literature, The Arts, and the Manners of the Athenians." See Shelley: Prose Works Vol. 2., Ed. Richard Herne Shepherd, London: Chatto \& Windus, 1897, pp. 39-47.
} 
that had marginalized them for so long as the "other"' (3) in national matters, here we witness a failed attempt by the Chorus members to include themselves in Greece's forging of a new national identity. The Chorus, finally realizing that the stories of Jason and Medea, Orpheus and Eurydice, and Ulysses and Penelope are not in fact idealistic, objects to a new Troy (“O, write no more the tale of Troy") and the Greek imperialism and misogyny it symbolizes, as well as opposes the return of Oedipus ("Riddles of death Thebes never knew"), the famous king who accidentally killed his father and begot children with his mother. Looking to Ancient Greece turns out to be precisely the wrong move for these women who seek better circumstances. By denying both Greek history (the Trojan War) and mythology (Oedipus), the women acknowledge the fact that retreating to an idealized Ancient Greek past is an unfeasible proposition, as unfeasible as was the Greco-Ottoman warfare about which they remained informed from the seraglio.

The Chorus's disillusionment culminates with the poem's well-known final lines:

O cease! must hate and death return?

Cease! must men kill and die?

Cease! drain not to its dregs the urn

Of bitter prophecy.

The world is weary of the past,

O might it die or rest at last! (1096-1101)

Although the Chorus here seemingly rejects historicity, I would instead argue that these final lines challenge readers to meditate upon mankind's history of violence and to reject as fantasy the argument that the past can be revived for contemporary political and cultural uses. As William A. Ulmer writes, the Chorus's closing lines "call into question the order of history, 
which the Greek women wearily depict as a spectacle of men hating, killing, and dying ... these lines also seek an escape from repetition" (620). The women have become enlightened about the futility of war, unlike the Greek and Ottoman men fighting in the revolution, and express a desire for people to become more humane. The Chorus's lament, like laments in Ancient Greek drama which critiqued wartime ideology (Dué 164), becomes a statement opposing the direction in which the Greek War of Independence is advancing. In The Persians, Xerxes's and the Chorus's lament was meant to exact sympathy for the Persians from an Athenian audience, compelling them to reflect upon the brutality of war. The Chorus of Greek Captive Women's lament functions in a similar way: as an appeal for sympathy from Shelley's readers, who were to recognize the precarious position in which the women find themselves as captive females with limited knowledge of a war whose direction and outcome they are unable to influence. As Hellas ends, Shelley's readers are left to ponder how (ab)uses of the Hellenic past exacerbate religious and ethnic tensions, putting the Greeks in a precarious political and cultural situation and thus bringing Greece (and because this is Shelley, the world) even further away from true liberation.

\section{“Zö̈ Mou, Sas Agapo": Greek-British Relations and Western Dominance in Reine Canziani}

Although Shelley's Chorus is bereft of solutions about Greece's future at the end of Hellas, the poet himself believed Britain should assist Greece. As he writes in Hellas's Preface: “The wise and generous policy of England would have consisted in establishing the independence of Greece, and in maintaining it both against Russia and the Turk" (448). For Shelley, England's participation in the Greek War of Independence on behalf of the Greeks would ensure that the Russians did not defeat the Ottomans only in turn to enslave the Greeks. British intervention could also prevent Russia from establishing a Greek state in which Orthodoxy, the two countries' shared religion, was given precedence. Shelley objected to Russia's involvement in Greece 
because their victory over the Ottomans would symbolize the triumph of Christianity over Islam, a conception of the war to which Shelley was opposed, as is apparent from reading Hellas. With British assistance, on the other hand, Greeks could establish an independent and democratic nation. As Stephen Minta clarifies, British intervention would help to form Greece into a "unitary, secular, and constitutional state, in which law and administration were conducted along western lines" (131). Despite his personal objections to the Tory British government, Shelley believed his country was instrumental in helping to create a westernized Modern Greek nation.

Publishing her novel Reine Canziani three years after Hellas, Catherine Grace Godwin, too, writes in support of Greek freedom and, like Shelley, critiques a philhellenism that, in promoting Greek freedom, disregards the realities of Modern Greece. ${ }^{13}$ However, while Shelley targets primarily European governments who ignore Greece's plight and critiques philhellenes in order to encourage them to reconsider their uses of philhellenic rhetoric (but not to discourage their activism), Godwin instead denounces liberal philhellenes who she believes intervene in Modern Greek politics without an authentic understanding about, or sincere concern for, the modern populace.

In order to expose liberal philhellenes as opportunistic and disingenuous, Godwin makes a bold authorial move by modelling her deceptive leading man, Monthermer, on perhaps the most famous European philhellene of them all: Lord Byron. Indeed, Godwin's modelling of Monthermer on Byron did not go unnoticed in reviews of Reine Canziani, including those in The Literary Gazette, The Gentleman's Magazine, and the Philomathic Journal, the reviewer for the latter writing that "[s]ome parts of the present tale seem to have relation to the life and character

\footnotetext{
${ }^{13}$ It is important to note here that, though Godwin does not explicitly mention the Greek War of Independence, Reine Canziani considers Greek "emancipation" from the Ottomans and from Westerners like Monthermer throughout the narrative. Publishing her novel in 1825, Godwin clearly has the Greek war, and Greece's liberation, on her mind. Reine's trials and tribulations are a personalized narrative of a broader national struggle.
} 
of the author of 'Childe Harold"' (209). ${ }^{14}$ In Chapter Two, I argued that Byron's championing of Modern Greek vernacular literary culture and language in his 1812 publication Childe Harold's Pilgrimage gestured toward his broader support for a stronger intercultural relationship between Greece and Britain. Byron sought to move away from solely classical conceptions of Greece and to familiarize British readers with a contemporary culture with which they were very little acquainted. In 1823-24, the two years preceding Reine Canziani's publication, Byron solidified his legacy as Europe's most famous philhellene when, encouraged by the London Greek Committee, he travelled from his home in Italy to Greece in 1823 to support the Greek revolution, both militarily and (more importantly) financially. Byron's Greek mission represented a significant step in the Europeanization of Greece and in European politics more generally. As Roderick Beaton writes: "His most important achievement was this, in concert with Mavrokordatos: not just to import European values into Greece (though he certainly did that too), but to try and create, in Greece, political conditions that could then be emulated by the rest of the continent" (266). Although he died unexpectedly in Messolonghi on 19 April 1824, Byron's decision to support the Greek cause nevertheless contributed to Europe becoming more actively involved in Greece's bid for independence.

For Godwin, however, Byron and his legacy exemplified something far less ideal. In her opinion, Byron's journey to Greece represented that of the Anglo-centric traveller who brought his own cultural values and preconceptions to bear on Greece and its people. Regardless of Byron's genuine concern for Modern Greece, Godwin recognized that the poet's literary legacy, and later journey to Greece, inspired a legion of European philhellenes to travel to Greece, many

\footnotetext{
${ }^{14}$ See "Reine Canziani; A Tale of Modern Greece," The Gentleman's Magazine and Historical Chronicle, August 1825: 156-57; "Reine Canziani, a Tale of Modern Greece," Literary Gazette: A Weekly Journal of Literature, Science, and the Fine Arts, May 1825: 344; and "Reine Canziani, a Tale of Modern Greece," Philomathic Journal and Literary Review IV (1826): 208-9.
} 
of whom had little real knowledge of the country. As St. Clair notes, "[m]en began to make their way to Greece as a direct result of hearing that Byron had gone there" (176). By basing Monthermer on Byron, Godwin diminishes not only the famous poet's efforts on behalf of the Greeks, but that of the many Europeans he inspired to travel to Greece to fight alongside the Greeks, exposing their philhellenism for what she believes it really is: Orientalism. As Stathis Gourgouris argues of philhellenes who attempted to Europeanize Greece:

For, precisely in dissociating itself from the Orient, Philhellenism reveals its ultimate discomfort with modern Greece, at least with modern Greece as a cultural reality. In this way, we can speak of two moments in Philhellenism, two moments whose inherent antithesis will eventually display overtly the "antiHellenic" essence of its discourse: First, we can speak of a Philhellenism of ancient traces, which seeks and enjoys its intoxication amidst ruins and legendsthis constitutes Philhellenism's explicit utterance. Second, we can speak of a Philhellenism of a contemporary resurrection of ancient traces, if you will. Byron exemplifies this second site, which is inextricably interwoven with the Oriental.

According to Gourgouris, the philhellenism practiced by philhellenes like Byron was essentially a form of Orientalism as it sought to efface Modern Greek culture in forging a contemporary Greek nation state. When reading Reine Canziani, then, it is instructive to think about the interstices between philhellenism and Orientalism and how some Europeans promoted philhellenism not only to help liberate the Greeks, but to maintain power over them. For Godwin, I argue, philhellenism was more sinister than it appeared when it was adopted by Europeans who used its rhetoric to privilege the West over Greece, to advance their own personal and political 
agendas, and to actualize their own classical learning, thereby making themselves masters of a past culture which they had been trained to regard as being their own inherited legacy.

In Reine Canziani, Monthermer represents the British traveller who practices an Orientalist philhellenism by imposing his cultural values and beliefs on the Greeks while disregarding those of the local population. Readers are introduced to Monthermer early on in the text when the titular heroine Reine Canziani- the fifteen year old daughter of George Canziani, a wealthy merchant of Constantinople, and his wife Eudora—spots him at a Greek religious festival:

[A]midst these strangers was one, whom it would have been impossible to have passed undistinguished amidst a thousand ... Every movement of his fine form was replete with dignity - every varied expression of his features gave utterances to a volume of thought, and brought into notice innumerable graces; and, though his complexion was pale ... it would have been vain and presumptuous to have said that the diminishing of one shade, or the addition of one hue, could have perfected with more exquisite beauty the work of the Creator. (1.10-11)

Important to note here, I think, is Reine's immediate and strong attraction to Monthermer. In this scene, Godwin (through free indirect discourse) reveals how Reine, with "her susceptible heart" and "the seductive softness of her nature" (1.8), feels the intensity of the Greek-British transcultural interaction. And even if her heroine tries to resist her attraction to Monthermer by noting his differences - "his complexion was pale"- and by pulling her veil over her face to avoid his gaze (like Owenson's Ida before her), she finds herself (unlike Ida) constantly thinking about the British man after their initial encounter. "Reine pondered much on the stranger who had gazed on her so intensely, and yet felt surprised why she did so" (1.14) writes Godwin, 
foreshadowing the devastating hold Monthermer has over the Greek girl (id est Greece) as the novel advances.

Monthermer and Reine become more fully acquainted following this episode, when the Englishman is forced to take up residence with the Canziani family after a fire reduces half of Pera (a district in Constantinople, home to a Greek majority) to ashes, including the guest home he had been staying in with the Paleopulo family, friends of the Canzianis. While Monthermer is a guest of the Canziani family, Godwin explains why he has travelled to Greece. Like Byron before him, Monthermer departs England under mysterious circumstances and with many "accusers" (1.39). Godwin clarifies that Monthermer had fallen in love with a woman (Eugenia) with whom he should not have—again, just like Byron had with his sister Augusta Leigh. ${ }^{15}$ Monthermer travels to Ottoman Greece in order to forget his past life and while there, decides "to become more familiar with the habits and domestic characteristics of the Greeks" (1.53) and, like many European visitors before him, to "ascertain how much of the spirit of ancient times yet remains in these Greeks" (1.54). With Reine's father George and his friend Paleopulo, Monthermer even discusses the prospect of Greek liberty. Godwin writes that the two Greek men "loved and venerated the noble-minded Englishman, who bewailed with such deep sympathy the degradation of their adored country, who prophesied with such enthusiasm her restoration to her rights as a nation, and who opened to them such extensive, such enlightened views of the political state of Europe" (1.59-60; italics mine). While Monthermer's sentiments are ostensibly noble, his idea that Greece's "rights as a nation" can be restored and his prioritization of the "enlightened views of the political state of Europe" demonstrate the Englishman's lack of understanding about, or respect for, how contemporary Greek society is structured and how it

\footnotetext{
${ }^{15}$ Perhaps it is coincidental, but the names "Eugenia" and "Augusta" are linguistically related. The former is Greek for "well born" and the latter is from the Latin for "majestic."
} 
functions. That is, he assumes Greeks understand the concept of "nation" and that they would want to model their country upon the nations of Western Europe.

To be sure, Monthermer's proclamation following his rousing ideas about Greek freedom and nationhood reveals just how detached from the realities of modern Greece he is:

"The day will come," he would exclaim, "when the whole world shall be free. Men's minds shall throw off their prejudices, the religion of the heart—of nature, shall prevail; there shall be no conformity to creeds, no bowing down to idols, no repetition of vain and visionary fables, no homage extorted by the despot from the slave - there shall be an emancipation of the mind—reason shall reign the universal God." (1.60-61)

By linking Monthermer's ideas about Greek freedom to his Enlightenment belief in "reason" over faith, Godwin suggests that the Englishman's commitment to Greek independence is fueled by his own secularism and irreligiosity rather than concern for the Greeks. Monthermer takes up the cause of Greece merely to gratify his own impulses and philosophies rather than to help its people. Indeed, the two Greek Orthodox men to whom he speaks do not understand the meaning of Monthermer's words, which Godwin writes "sounded strange in ears unaccustomed to such doctrines" (1.61). Monthermer does not attempt to truly understand the Greeks or the Ottoman society in which they live but instead tries to impose his own cultural views upon them.

The ruinous effect of Monthermer's presence in Greece, in turn, is reflected by the devastation he causes the Canziani family. George Canziani is accused of treason to the state and imprisoned by the sultan because of his acquaintance with Monthermer, who is believed to be a Russian spy. As one of the sultan's janissaries tells George: "You harboured a spy, sent by a foreign government, to instigate the Greek inhabitants of these dominions to rebel against the 
laws, and to league with the Russians and rebel Pashas" (1.142). Although Godwin never clarifies whether or not Monthermer is truly a Russian spy, his presence in the Canziani household nonetheless causes the demise of the family as George is imprisoned, Eudora dies in Constantinople trying to secure her husband's freedom, and Reine is forced to flee her home when janissaries come to Belgrade Forest in order to bring her to the sultan's harem. Moreover, even if the Englishman is not solely to blame for the Canziani family's destruction, Godwin suggests that Monthermer stands to benefit from Reine's familial displacement. In fact, in the chapter prior to George's arrest, Monthermer had posed a temporary threat to the domestic life that had safeguarded Reine from foreign men like him when he entered the young Greek woman's bedroom and asked her to elope with him. Although Reine had then rejected his proposal and been saved by her mother's timely presence in her bedroom, the scene indicates how dangerous Monthermer potentially is if Reine is not protected from men like him within the confines of the domestic sphere.

Indeed, Reine Canziani draws from the Romantic-era anti-Jacobin novel when Godwin depicts the dangers that befall Reine when she is forced from the domestic sphere. ${ }^{16}$ Initially, it is not Monthermer, but instead the Ottoman characters in the novel, who threaten Reine's wellbeing. Reine, having escaped the janissaries who raided her home and killed her fiancé Constantine Marmaratouris (whom she had ignored because of her infatuation with Monthermer) attempts to secure safe passage to Smyrna, only to be abandoned on a small patch of sand somewhere in the middle of the Sea of Marmara by the Turkish sailor Seid when she refuses to relinquish her jewelry. Although Reine is quickly saved by Hussein Pasha (whom she later learns had paid Seid to strand her at a particular spot at sea), she is forced to live in his harem before

\footnotetext{
${ }^{16}$ Kevin Gilmartin provides a comprehensive and astute analysis of anti-Jacobin literature of the Romantic era in Writing Against Revolution: Literary Conservatism in Britain, 1790-1832, Cambridge: Cambridge University Press, 2007. Chapter 4 of Writing Against Revolution addresses the anti-Jacobin novel.
} 
being notified that Hussein is giving her to his colleague Ali Pasha, vizier of Epirus, as he had previously gifted Hussein two Albanian slaves. As Godwin writes,

When the wily Pasha found that so fair a prize had unexpectedly fallen into his hands, he at first determined to appropriate it to his own pleasures; but, on further consideration, other views presented themselves. He had recently signed a treaty of amity with the Pasha of Albania, once his bitterest enemy ... and he resolved, in this instance, to sacrifice his own gratification to his interest, designing the daughter of Canziani ... as a gift in return for that he had received from the voluptuary Ali. (1.298-99)

In the episodes featuring Ottoman characters, Godwin illustrates the various dangers that confront Reine. Forced to flee Belgrade Forest, Reine is outside of the home treated like a commodity by the Ottomans, who trade her (body) amongst themselves in order to make both capital and political gains. Although Godwin does not explicitly state that either Hussein Pasha or Ali Pasha will (ab)use Reine sexually, she implies as much when she writes that Hussein Pasha resists "his own pleasures" and "sacrifice[s] his own gratification" (1.299; italics mine) only because doing so will benefit him politically. Throughout Reine's encounters with the Ottomans, her body is at constant threat as her sexuality becomes her most prized asset. If the Ottoman East (coded masculine) poses a danger to the young Greek woman's selfhood, the European West might serve as a positive counterbalance to this threat. Indeed, Godwin offers this possibility when Reine, headed to Ali Pasha's court at Tepaleni (Tepelenë, in present-day Albania), is saved by Monthermer, who miraculously appears to kill her Ottoman captors/attendees. Naturally, Reine is grateful, as she had believed before the Englishman's arrival that "there is no hope, death alone can release me from this hateful degradation; the rocks 
may fall around me; the earth may open, it is true, and overwhelm me; nothing else can avert the evil which threatens me" (2.18). Monthermer's appearance in the novel after an extended absence, then, comes as a godsend for the young Greek woman and provides the possibility that all will end well for Reine. However, almost immediately following her rescue by Monthermer, Reine "remembered her sainted mother's warning" (2.21) about her love for the Englishman, leading her to question her association with him:

Who was this strange mysterious man, with whom her fate seemed linked by some indissoluble tie? The world had stript her of all else, and left her only him. Ought she to cling to him? Ought she to yield again to that love, which every hallowed thing had commanded her to abjure? Ought she not rather to throw herself on the mercy of the midnight banditti, or on the rude protection of the inhabitants of these wilds, to stretch forth her hands to the rugged mountains, to the rustling reeds, the dark forests, and call on them to aid her? Would not even this be fraught with less of evil, than thus to place herself in the power of one whose love, ay even whose very presence had been so unblest to her? It might be, but there was a small voice in her bosom that over-ruled these arguments. (2.21-

Because Godwin's novel was published during the Greek War of Independence, Reine's conjectures about Monthermer should be read, I suggest, more broadly as a commentary on Greek-British relations. Reine, as a symbol of Greece, considers Monthermer "strange" and "mysterious" but thinks to herself that her "fate seemed linked [to him] by some indissoluble tie." "Stript...of all else," Godwin tells us, Reine must ask herself the question that Greece too had to ask itself about Britain (and Europe) during the war of independence: "Ought she to cling 
to him?" Although she doubts Monthermer's intentions, Reine feels he is her only potential for salvation.

The gendered formulation of Greek-British relations (with Greece as female and Britain as male), which I argue Godwin dramatizes through her portrayal of Reine and Monthermer's relationship, gestures more broadly toward Western European discourses about, and depictions of, Greece in the early nineteenth century. In particular, European art of this period went the furthest in popularizing the idea of a feminized Greece in Europe. In fact, the artist who was perhaps most famous for his depictions of a female Greece, the Frenchman Eugène Delacroix, had exhibited Scenes from the Massacres at Scio (1824) at the Salon in Paris only one year prior to Reine Canziani's publication. In this painting, Delacroix represents a scene from the 1822 massacre of approximately 20,000 Greeks on the island of Chios by Ottoman forces (a popular topic that Hemans takes up in "The Bride of the Greek Isle"). Strikingly, at the forefront of Scenes, Delacroix features Greek female victims, including a naked woman bound by her Ottoman captor to his horse and a dead mother whose infant attempts to suckle at her breast. Like his later Greece on the Ruins of Missolonghi (1827)—which goes even further in equating "woman" and "Greece" by representing the country as a female standing on ancient ruins and a dead body under those ruins - Scenes invites viewers to envision Greece as a country of females in distress who require external intervention (i.e. European, male). However, it is important to note that, although Delacroix's paintings were some of the most famous depictions of GrecoOttoman warfare during the Greek revolutionary period, his feminized Greece already possessed cultural currency by the time he set out to portray the country as female. As Thomas Crow asserts, "[t]he stock images to which Delacroix resorted were current in journalistic and literary responses to the massacres" (71). Delacroix did not pioneer the concept of a female Greece but 
rather contributed to the further popularization of a mythos about the country that was already firmly in place. ${ }^{17}$

Depictions like Delacroix's of a female Greece, in turn, fed into Orientalist renderings of the Ottomans - who are portrayed in Scenes as tawny-skinned men with turbans, scimitars, and guns - which further inspired European intervention in Greek affairs. In fact, Darcy Grimaldo Grigsby writes that, during the Greek War of Independence,

$[E]$ nslavement by the oriental enemy had come to be associated with the incarceration and sexualization of white Christian women within the harem ... In 1822 a British consul could report that "The females of Scio [Chios], renowned for their beauty, many of them respectable, are become the property of the captor, reserved for the Harems or domestic servitude." In his Salon review of Delacroix's Chios in 1824, August Jal conjured "virgins consecrated to the cult of the mother of God" transported to the "harem" of "infidels." (294)

Liberal discourse in Western European countries promoted and perpetuated a view of Greco-

Ottoman warfare that saw the conflict as one in which Greek women were being abused by licentious Ottoman men (hence the many references to harems), a public opinion that was in turn

\footnotetext{
${ }^{17}$ In "The Creation of Modern Greece: Travel, Art and Philhellenism in the Collection of the State Library of Victoria" (La Trobe Journal 82 [2008]: 66-87), Spiridoula Demetriou examines early nineteenth-century sketches and paintings representing Greece. One of these images is Greece Expiring among Classical Ruins, the frontispiece to Compte de Choiseul-Gouffier's Voyage Pittoresque de la Grèce (1782). Importantly, Demetriou argues of Greece Expiring that " $[\mathrm{t}] \mathrm{he}$ enslaved personified Greece in a female form in the image is pointing to the surrounding decaying monuments, which also functions to remind the viewer that classical civilization was the conduit between the West and contemporary Greek population. A major aspect of foreign support for the cause of Greek liberation therefore was prompted by the West's cultural relationship with classical civilization" (77). In this way, too, we can see how Greek women and classical ruins became conflated in the European imagination. Another image Demetriou examines is $O$ Miserable me, Doomed to Slavery, the frontispiece to the Greek-French writer Adamantios Korais's Salpisma Polemistirion (1801). The image "depicts a personified Greece at the mercy of a dispassionate, scimitarwielding Turk in the midst of relics that metonymically take the country back via history to the ancients" (78). Demetriou claims that, in this image, "[t]he raised arms of the personified Greece suggest resurrection, or rebirth of contemporary Greece as a political entity. They also form a posture of supplication that addresses a plea for help to the viewer ... The ragged state in which Greece is presented to the viewer appears to be squarely the fault of her Turkish overlord" (78).
} 
popularized by art works like Delacroix's. This cultural context, I suggest, is important to understanding the complexity of Godwin's portrayal of Reine and Monthermer's relationship. Specifically, though Godwin draws upon (mostly male) European discourses which portray Greece as a woman in need of rescue, and thus invite European male intervention, I would argue that she reconstructs this narrative by equating the Western male with the licentious Eastern male. In fact, in the passage from Reine Canziani that I last quoted, Godwin begins to debunk the idea that the Westerner, Monthermer, will save Reine from the oppressive East, as she has her heroine anticipate that the Englishman poses greater danger than he does protection and consider "the midnight banditti" and "inhabitants of these wilds" as safer alternatives to him (2.22).

In her portrayal of Reine and Monthermer's relationship, Godwin effectively revises the gendered (and racial) discourses of the Greek war by suggesting that Europeans can be as guilty as Ottomans of abuse toward the Greeks. She does so, I contend, in order to critique a liberal European philhellenism like that which she attributes to Byron (and those inspired by his example) which called for European intervention in Greco-Ottoman affairs. It is not coincidental that Monthermer, once he has saved Reine, calls himself "a solitary man, a traveller, or as they have it, a Giaour" (2.20), a nod to one of Byron's best-known works. Soon after, Monthermer tells Reine, "[m]y dreams of good in early life outstripped the truth-I followed phantoms, until weary of the chase, of mankind, of myself, I left them, loathing all” (2.31), here referencing another of Byron's famous poems: Manfred. Moreover, Monthermer's proclamations about Greece once he has rescued Reine would surely have reminded readers of Childe Harold's Pilgrimage, with the Englishman casting "his delighted glance over the Arcadian scenery" and "recall[ing] the faded glories of the land" (2.24). 
Monthermer's classicizing impulses, though not necessarily troubling on their own, become so when he yokes them to a romanticized Greek fantasy and demands that Reine embody the Greek ideals that he fancies. Taking Reine to Athens, Monthermer creates a world for the two of them directly from his classical studies and imagination, starting with a residence that is "fitted up in a style of elegance, bearing marks of European taste, united with oriental luxury" (2.60). "His whole life," Godwin informs her readers, "was now a poetic vision put into practice" (2.70), a poetic vision which, most troublingly, depends on Monthermer forcing Reine to abandon her indigenous identity, a process symbolized by the Englishman's alterations to her clothing:

Her very dress was now arranged to accord with his poetic fancy. She no longer wore the rich silks of the East; no contrasting colour was permitted to glare on the pure white of her flowing drapery:- no embroidery, no decorating jewel, bordered her robe, which was modelled after the most beautiful statues. A cestus, studded with classic gems, and a bracelet in the form of a serpent, that favourite figure of the ancient, and symbol of eternity, richly wrought in gold, and clasped around her beautiful arm, were the only ornaments he permitted her to wear. Her dark tresses were simply and closely confined with a silken fillet, and clustered in full waves on the top of her head, as they are usually seen in the busts of Sappho. The classic lyre, with its golden strings, was now placed in her hands. Thus attired, with what rapture did Monthermer behold her! -Could Psyche be more beautiful? Could the Muses be more divinely graceful?_-"She is an angel," he cried; "nothing on earth can equal her-she is an angel, and she is mine." (2.70- 
In Topographies of Hellenism, Artemis Leontis explains that "[e]arly in the nineteenth century, Europeans began to deploy in Hellas the narratives, methods, rules of conduct, modes of expression, and institutions of the discourse of Hellenism. These functioned as disciplinary technologies" (56). In this scene, Godwin demonstrates precisely how Monthermer draws from the "discourse of Hellenism" in order to dominate Reine and force her to adhere to what he believes Greek women—and thus, "Greece" more generally—should resemble. Specifically, the “disciplinary technologies" Monthermer employs regulate Reine's body and force it to express a Greek identity more in line with European fantasies than with cultural realities. By removing Reine's "silks of the East" and replacing them with "pure white" drapery; forcing a "cestus" (or girdle) around her waist; fixing her hairstyle "with a silken fillet"; and placing a lyre into her hands, Monthermer produces an (Ancient) Greek fantasy that he feels so attached to that he is compelled to call it "mine."

By demonstrating how Monthermer forces Reine to personify his classicized ideals, Godwin critiques philhellenes who imposed their own cultural values on Greeks while purporting to protect their interests. Although Monthermer, as a Westerner, is supposed to defend Reine from a violent Ottoman masculinity, he instead disciplines her body just as the Ottomans do, and takes their abuse one step further by partaking in a form of Orientalism against Reine, altering her appearance in ways that strip the young Greek woman of her indigenous Eastern identity. Forming Reine into his conception of the classical ideal by altering her appearance, Monthermer forces the Greek woman into his sphere of power and influence wherein he is able to control and abuse her. In fact, just as she had done earlier in the novel, Godwin reveals the damaging effects of Monthermer's classicism by linking it to his depraved sexuality and irreligiosity. Living together with Monthermer out of wedlock, Reine repeatedly tells him "her 
earnest wish that the established forms of her church might sanctify their union" (2.89), only to be informed by the Englishman that she is a slave to "Custom" (2.89). According to Monthermer, there is no "utility" or "beauty" (2.90) in tradition and he encourages Reine to consider "Nature . . o our priest" (2.91) instead of desiring a religious marriage. Rather unsubtly, Godwin here attacks an abstract universalism which she considers damaging to Greek (and British) traditions and emphasizes the link between Monthermer's dangerous philosophies and Byronic philhellenism when she has Monthermer tell Reine "Zoë mou, sas agapo" as he abandons her, the phrase coming from Byron's "The Maid of Athens," a poem penned during his first visit to Greece. $^{18}$

After Monthermer leaves for England indefinitely (despite claiming he will return to Greece), Reine learns from a British tourist and artist named Eustace that Monthermer has married a woman named Eveleen and become Lord Avlone, a discovery that causes Reine to die of heartbreak in an ending that acts as the final indictment of Byronic philhellenism. Although the novel ends perfunctorily with the titular character's death, hastened by an exploitative and cruel foreigner's intervention in her life, Godwin complicates Reine Canziani's depiction of philhellenism and Greek-British relations by introducing near the conclusion of the novel the character of Athenais, Monthermer and Reine's illegitimate daughter, born after the Englishman's departure for Britain. While Reine Canziani had in the main depicted philhellenism as being detrimental to Greece, the ending of Godwin's novel offers an alternate vision when the British Eustace offers to bring Reine to England and, together with his family, to care for the Greek woman and her child. Though Reine declines his invitation for herself, she instructs Eustace to bring Athenais with him: "Let your country adopt her as a daughter, let her

\footnotetext{
18 "Zoë mou" is a pet name that means "My life." "Sas agapo" means "I love you."
} 
acquire your manners and your language, let her never hear the name of her father; impress on her infant mind, that she was born of Greek parents" (2.205).

Godwin here, I propose, addresses the geopolitical consequences of Greek-British relations on a microsocial level. The transcultural relationship between the two countries having materialized — as symbolized by Reine and Monthermer's love affair — Godwin suggests that Greeks and Britons must attend to this reality. However, if Athenais is to be "adopted" by Britain and "acquire" the manners and language of its people, does this not merely confirm the cultural hegemony of Britain over Greece that Godwin had critiqued throughout the novel? Indeed, even Eustace's well-intended teaching of Athenais - he brings her to the Acropolis and encourages her "to direct her attentions to those monuments in which her ancient nation stood unrivalled" (2.232) — must remind readers of Monthermer's earlier (Byronic) archaizing of the modern topos. In the end, Reine's proposals about a possible future for Athenais are not fully explored in the novel's narrative, leaving readers to speculate on the young Greek girl's life following her mother's death. While Godwin recognizes the necessity of rethinking Greek-British relations, she chooses not to (or, cannot) propose any concrete solutions to amend the power imbalance between the two countries. Instead, Reine Canziani concludes by directing readers' attention to Reine's grave where "[f]ew sounds disturb the sacredness of the spot" (2.291), a move that works to memorialize Modern (instead of Ancient) Greeks, but which also makes death the impetus for European concern about Greece, a point that would have been especially pertinent in the context of the Greek War of Independence.

\section{"Man May Not Fetter, Nor Ocean Tame / The Might and Wrath of the Rushing Flame!": Greek Female Self-Determinism in "The Bride of the Greek Isle"}

In my analyses of Hellas and Reine Canziani, I focused on Shelley's and Godwin's depictions of Greece as woman (or women) in distress. Like Shelley and Godwin, Hemans too asks readers to 
correlate Greece with female suffering, featuring in "The Bride of the Greek Isle" a young Greek woman named Eudora who is kidnapped at her wedding by pirates who murder her entire wedding party, including her husband-to-be, Ianthe. I argue, however, that "Bride" sets itself apart from the gendered politics of Hellas and Reine Canziani by ending with Eudora lighting her captors' ship (and herself) on fire, and thus taking her destiny into her own hands rather than despairing over her fate, as do Shelley's and Godwin's more passive heroines. Eudora's moment of autonomy is important, I suggest, because it represents women as powerful nationalist agents and resists the narrative that promoted European male intervention in Greek affairs. In my discussion of Reine Canziani, I examined early nineteenth-century depictions of Greece and argued that these works presented Greece as a suffering female in order to encourage (male) European intervention in Greco-Ottoman affairs. By featuring defenseless female protagonists, Hellas and Reine Canziani to an extent adhere to the problematic sexual politics of early nineteenth-century European art and literature that represented both Greece and women as powerless, even if Shelley and Godwin meant for their works to emphasize the ways in which European philhellenism disempowered Greeks (and women). Hemans, on the other hand, foregrounds a Greek female protagonist not to confirm but instead disrupt the sexual politics of early nineteenth-century philhellenic representations of Greece. In so doing, Hemans argues that Greeks - and women — could actively contribute to their own nation's destiny rather than depend solely upon foreign intervention.

Hemans signals her intention to complicate the gender politics of the Greek War of Independence by beginning "Bride" with an epigraph from Lord Byron's Sardanapalus. ${ }^{19}$ In Sardanapalus, Byron represents the titular Assyrian king as an effeminate ruler who adopts his

\footnotetext{
${ }^{19}$ This epigraph does not appear in the poem's initial 1825 publication in the New Monthly Magazine; Hemans includes it in her 1828 Records of Woman.
} 
gender role as a "politics of evasion" (Wolfson "A Problem Few Dare Imitate" 868). ${ }^{20}$

Sardanapalus does not want to lead a militaristic, war-mongering empire, telling his Greek harem girl Myrrha "'I loathe all war, and warriors; / I live in peace and pleasure"” (2.1.529-30). Myrrha, though, challenges the Assyrian's correlation between effeminacy, femininity, and passivity by imploring her lover to fight for his empire and by partaking in battle herself. Throughout the play, Myrrha attempts to convince Sardanapalus to embrace his masculinity and, by extension, his imperial rule. In time, Myrrha's implorations are effective and Sardanapalus does partake in battle. Importantly, though, the young Greek woman's success in convincing Sardanapalus to fight comes at the expense of the Assyrian king's resolve to remain effeminately passive and contributes to a dream in which he is raped by his masculinized grandmother Semiramis (former leader of the empire), from which he awakens into the arms of Myrrha (thus conflating the two women). Byron's Sardanapalus critiques the gendered discourse of empire and the need for imperial leaders to practice a destructive hyper-violent masculinity in order to maintain power (a masculinity that affects both men and women, as evidenced by Sardanapalus's dream). In fact, at the end of the play, Sardanapalus and Myrrha create their own funeral pyre, "a light / To lesson ages" (5.1.440-41) about the futility of empire, an institution that is for Byron ultimately selfconsuming. By having Sardanapalus and Myrrha self-immolate, Byron "drives toward a conclusion which effaces the system that made gender matter. ... [I]mmediate history with its entanglements of gender and empire is cancelled" (Wolfson, "A Problem Few Dare Imitate" 892).

Hemans alludes to Byron's play at the start of her poem in order to signal her own critique of the destruction imperial politics causes for Greeks (Eudora's entire wedding party is

\footnotetext{
${ }^{20}$ Sardanapalus first enters the play, as per Byron's stage directions, "effeminately dressed, his Head crowned with flowers, and his Robe negligently flowing, attended by a Train of Women and young Slaves" (435).
} 
murdered by invading pirates) but also, more broadly, of the gendered discourse of national identity. If the virility of an empire was judged by its leader's degree of masculinity, a nation's strength was determined by the patriotism of its men, a patriotism based on their willingness to fight for their country (coded: masculine). ${ }^{21}$ For Hemans, though, associating men with a "masculine" patriotism creates a nationalism that imposes a certain gendered identity on women that discounts their contributions to the nation. In fact, I suggest that the lines from Sardanapalus that Hemans quotes demonstrate her commitment to re-imagining the role of women and gender in the nation:

Fear!-I am a Greek, and how should I fear death? A slave, and wherefore should I dread my freedom?

I will not live degraded.

-Sardanapalus

Although Hemans presents this excerpt as the voice of one character, it is in fact a conflation of two: the first two lines are spoken by Myrrha (1.2.479-80) and the last is spoken by Sardanapalus (1.2.629). Hemans quotes these lines, I suggest, in order to link her heroine Eudora to both a "masculinized" Greek woman unafraid to fight for her freedom and an "effeminate" king who challenges the gender norms of his society, even if it means the collapse of his empire. More than this, though, by extracting these lines from a scene in which Myrrha attempts to convince Sardanapalus to fight for his empire, and in which the Assyrian king tries to persuade his Greek slave that pacifism is preferable to war, Hemans directs her reader's attention to Myrrha and

\footnotetext{
${ }^{21}$ In his Romanticism and Masculinity: Gender, Politics and Poetics in the Writings of Burke, Coleridge, Cobbett, Wordsworth, De Quincey, and Hazlitt (London: Macmillan, 1999), Tim Fulford writes about the ways in which ideas about gender and sexuality were redefined during the Romantic period. Fulford suggests that some Romantic writers were preoccupied with rethinking ideas about gender and power and endorsed a "strongman" type of masculinity during this time in part because their country was at war with France.
} 
Sardanapalus's many conversations about empire and gender, and the lessons they teach one another. If Myrrha succeeds in convincing Sardanapalus to fight for his empire, the Assyrian king ultimately triumphs in their debates about imperial gender politics by convincing Myrrha to join him in a death by fire that works to reject a masculinist and militaristic system of governance that has caused the young Greek woman's subjugation in the first place.

Like Sardanapalus, "Bride" scrutinizes a gendered form of politics, but more so upon a national rather than imperial scale; specifically, Hemans is preoccupied with the Greek War of Independence, which was in its fourth year when the poem was published. Indeed, in the year preceding the poem's appearance, two momentous, and troubling, events occurred in wartime Greece: Lord Byron's death in Messolonghi in 1824 and Ibrahim Pasha's mass killings in the Peloponnese in 1825. Although Hemans does not refer directly to these events, the poem's setting indicates her engagement with contemporary Greek war: Chios (Scio), the site of Greek massacres in 1822. As Gary J. Bass relates, the massacre was "the worst atrocity of the war, and the defining moment of the conflict for most Europeans. Scio was a wealthy island in the east of Greece, precariously close to mainland Anatolia, known best to Europeans as Homer's home island" (67). Bass continues:

Unrelenting press coverage of the Scio massacre solidified British sympathies. "The most civilized, cultivated, and interesting people, the flower of Greece, have been, the greater part, exterminated," wrote the Times. The bloodbath shocked Europeans to the core, with the figure of twenty or twenty-five thousand dead in wide circulation. This number was probably exaggerated. But in an era when people had not yet grown inured to death tolls in the millions, Scio was a defining 
moment — remembered half a century later by the Times as "the most appalling chapter in the history of modern Europe.” (71)

Undoubtedly, Hemans's more astute readers would have understood her intention to speak to current events in Greece by situating her poem in Chios, although, as I will go on to discuss, the poet initially intentionally obfuscates the fact that her poem is about contemporary Greece.

Hemans's first footnote in "Bride" too illustrates how the poet draws from and alters another literary source in order to make her poem contemporarily relevant. She writes that her poem was "[f]ounded on a circumstance related in the Second Series of the Curiosities of Literature, and forming part of a picture in the "Painted Biography" there described" (345). Hemans here refers to Isaac D'Israeli's “Of a Biography Painted” in Curiosities (1823) and his description of the sixteenth-century Venetian Charles Magius's biography about his travels in the East, which consisted of a series of miniature paintings. Specifically, Hemans makes reference to D'Israeli's description of a painting of two ships lit on fire by a Cypriot woman who preferred death to slavery by her Ottoman captors: "The Turks are seen landing with their pillage and their slaves - In one of the pictures are seen two ships on fire; a young lady of Cyprus preferring the death to the loss of her honour and the miseries of slavery, determined to set fire to the vessel in which she was carried; she succeeded, and the flames communicated to another" (Painted 305). Clearly, Hemans was inspired by D'Israeli's description of this painting in which female heroism punctures a predominantly male narrative and which contrasted with paintings of the early nineteenth century that viewed Greek women as passively feminine, and she uses this historical episode to depict a moment of female national agency in contemporary Greece.

Initially, though, "The Bride of the Greek Isle" seems far removed from the atrocities of the Greek war and discussions of female nationalism. Instead, readers are presented a scene 
resonant of the ancient pastoral as preparations for Eudora and Ianthe's wedding commence. The poem opens with the speaker imploring "Come from the woods with the citron-flowers, / Come with your lyres for the festal hours, / Maids of bright Scio!” (1-3). When Eudora herself enters, she is "rob'd and crown'd" (5) while "Jewels flash'd out from her braided hair" (7), the image of an ideal bride. In the poem's second section (11.95-154), as Eudora leaves her home with her groom Ianthis, Hemans further emphasizes how idyllic the wedding ceremony is, describing a bucolic scene with a new home for the lovers "In the flowering depths of a Grecian wood, / With the soft green light o'er its low roof spread" (96-97). Hemans's diction in section two highlights the (initial) peacefulness of the bridal union, including her use of the words "soft" (97), "glow" (98), "gleam" (102), and "rays like a glancing river" (104) to describe the light in the forest scene and her reference to various forms of vegetation, including "lime-leaves" (99), "Citrons" (101), "Laurels" (103), “jasmine" (105), and "Vine-stalks" (106). The poem's bridal scenes create a pastoral world that is seemingly removed from that of the contemporary, and certainly from the realities of 1820 s Greece. Indeed, Hemans's wedding ceremony is reminiscent of the wedding scenes of Ancient Greece. ${ }^{22}$ To be sure, Ancient and Modern Greek weddings shared some common elements, including the proaulia (pre-marriage ceremony), the opening scene of "Bride" with the "maids" who attend to Eudora being an example of this type of ceremony. However, the gamos (wedding ceremony) in section two of "Bride," situated at the "fountainside" (112) where the groom and the wedding guests, wearing wreathes, "lifted the veil from Eudora's face" (113), is a distinctly ancient Greek wedding ceremony; in early nineteenth-

\footnotetext{
${ }^{22}$ For a comprehensive overview of weddings in Ancient Greek art and writing, see Robert Garland, The Greek Way of Life: From Conception to Old Age, Ithaca, N.Y.: Cornell University Press, 1990.
} 
century Greece, the couple would have wed at the Orthodox Church. ${ }^{23}$ Like many nineteenthcentury constructions of contemporary Greece, Hemans's "Bride" straddles the line between the ancient and the modern, but only temporarily, as I soon elaborate.

As idealistic as the poem's ancient pastoral scenes are, Hemans intimates early in "Bride" that they are constructed around a false ideal of womanhood (and thus, of Greece). Although Eudora looks the part of the conventional bride, the speaker informs readers that "a brow, as those gems of the ocean pale, / Gleam'd from beneath her transparent veil" (11-12). Eudora might don the outfit of a bride — robe, crown, braided hair, veil—but, as Hemans's focus on the young Greek woman's brow suggests, she possesses a character discordant with that of bride (and thus, wife) which is potentially disruptive to her culture's gender norms. ${ }^{24}$ In fact, the poem's speaker later comments that "the glance of her dark resplendent eye, / For the aspect of woman at times too high, / Lay floating in mists, which the troubled stream / Of the soul sent up o'er its fervid beam" (15-18). According to Susan Wolfson, these lines introduce the Greek woman's soul "as a site of trouble, a mysterious surplus for 'woman' . . If eyes are the windows of the soul, Hemans gives Eudora's soul a double-sexing, female and Byronic - the latter via 'troubled stream,' a signature of the Byronic hero" (Borderlines 304). Indeed, the speaker is disquieted by Eudora's unstable gender and, in the lines directly following those about her "dark resplendent eye" and perplexed soul, attempts to downplay her unconventionality by associating her troubled state of mind with having to leave her family home in order to marry. Instead, however, the speaker's description of Eudora, works to further complicate her gender as she is

\footnotetext{
${ }^{23}$ The lifting of the veil, called anakalypteria, was the most important act in the Ancient Greek wedding ceremony as it symbolized the transfer of the bride from her father to her husband's family. See John Howard Oakley and Rebecca H. Sinos, The Wedding in Ancient Athens, Madison, Wisconsin: The University of Wisconsin Press, 1993. ${ }^{24}$ Byron emphasizes the brows and eyes of his Byronic heroes, especially in his Eastern Tales, to indicate their transgressive and troubling natures. In The Giaour for example, the Giaour's "brow" is mentioned 11 times and his "eye" 10 times. See Lord Byron, "The Giaour," Lord Byron: The Major Works, ed. Jerome McGann, Oxford: Oxford University Press, 2000: 207-47.
} 
gendered male by the narrator who explains that 'She look'd on the vine at her father's door, / Like one that is leaving his native shore" (19-20; italics mine) ${ }^{25}$

Following the narrator's description of Eudora's sorrow is “The Bride's Farewell," a lay sung by Eudora which seemingly verifies the feminine sadness the speaker detects in the Greek bride. In the song, Eudora asks herself "Why do I weep?" (43), only to answer herself by stating "I leave my sunny childhood here, / Oh, therefore let me weep!" (49-50). Eudora laments that she has to leave her home, which includes her relationships with her sister, father, and mother. However, in the footnote to Eudora's lay, Hemans writes: "A Greek bride, before she quits her father's house, 'fait de tendres adieux à son père, à sa mère, à ses proches, à sesamies, A tout son voisinage, et aux lieux ou se sont passés les jours de son enfance._— En certains endroits, la douleur de la fiancée s'exprime par une formule d'usage.' Fauriel, Chants Populaires de la Grèce Moderne" (346). ${ }^{26}$ By citing the section of Fauriel's Chants Popularies where he indicates that a Greek bride's farewells ("adieux") to her family and friends are expressed by a standard formula ("s'exprime par une formule d'usage"), Hemans compels her readers to question the sincerity of Eudora's expressed sorrow. This is not to say that Eudora does not feel sadness for leaving her home; rather, Eudora's pain might go beyond the severing of familial bonds, which the narrator does not understand. Although it is never explicitly stated, it is possible that, as she prepares to leave her childhood home, Eudora recognizes herself as a commodity being transferred from one male (her father) to another (her husband), which is how Ancient (and Modern) Greek marriages were conceptualized and which might explain why Hemans chose the

\footnotetext{
${ }^{25}$ Interestingly, Hemans writes another poem, entitled "The Parting Song," about a male Greek youth who is forced to depart his home. See Felicia Hemans, "The Parting Song," Poems by Mrs. Hemans, London: George Routledge and Sons, 1885: 373-75.

${ }^{26}$ Hemans here references Claude Charles Fauriels's Chants Populaires de la Grèce Moderne, a work published in 1824 which popularized Romaic Greek folk songs in Europe. The excerpt from Fauriel's work that Hemans quotes translates as "bids tender farewells to her father, to her mother, to her relatives, to her friends, to all her neighbourhood, and to all those places where she spent the days of her childhood. — In certain points, the sorrow of the bride is expressed by a standard formula."
} 
name she did for her protagonist (Eudora in Greek means “good gift"). That Eudora's lay is spoken in iambic tetrameter (the poem's speaker narrates mostly in iambic pentameter) only further emphasizes that the song is in the form of a traditional folk ballad rather than a personalized lyrical profusion from the bride.

The first section of "Bride," I suggest, works to complicate ideas about sex and gender performance (contemporary and ancient) which, in the process, helps to confound idealizations of the ancient past and, ultimately, of Modern Greece. In her article "Fantasies of 'Woman': Hemans's Deconstruction of 'Femininity' in Records of Woman," Helen Luu argues that readers of "Bride" must distinguish between Hemans, who challenges cultural norms regarding gender, and her narrator, who is "debarred" from Eudora's subjectivity (44). By presenting a narrator who lacks access to Eudora's interiority, Hemans "calls into question not only the possibility of 'exploring', 'representing' or 'displaying' another's subjectivity, but also the very nature of the subjectivity seemingly represented or displayed" (Luu 44). The speaker of "Bride" cannot access Eudora's subjectivity and thus tries to "read" her identity through her body. However, in so doing, the narrator merely produces "the fantasy of femininity" (Luu 46), a version of the feminine in tension with "the glance of her dark resplendent eye" the narrator notices.

Hemans's subtle indications about Eudora's complicated gender, in turn, force readers to question the idealized bucolic wedding scenes the poet has constructed in the first two sections of the poem. Specifically, I argue that Hemans has intentionally lulled her readers into a supposedly distant land (and time) only to force them to confront the reality of Modern Greece's plight once the pirate horde disrupts the wedding ceremony, a reversal of the narrative methods of the two previous texts, in which the ancient past asserts its overwhelming presence. If, as Van Steen argues, "Modern Greece was subjected to the Eurocentric enterprise of the Orientalist 
production of a subordinate East" (171-72), it is with the arrival of the pirate horde that Hemans uses an Orientalist trope (pirates) in order to deflate the classicized Greece she has thus far constructed. Hemans's reference to D'Israeli's description of Ottoman pirates in Cyprus becomes most apparently relevant to Modern Greek politics when the poem's speaker declares "Fling down the goblet, and draw the sword! / The groves are filled with a pirate-horde! / Thro' the dim olives their sabres shine; - / Now must the red blood stream for wine!” (129-32). ${ }^{27}$ The contemporary political dimension of "Bride," which had been latent from the beginning but concealed by the poem's pastoral aesthetic, is brought to the forefront with Hemans's introduction of a pirate-horde to the wedding scene. Here, near the end of the poem's second section, Hemans deconstructs her own portrait of an idealistic Greek scene in a move that works to deflate philhellenism's promotion of a classicized Modern Greece. If, as Gourgouris argues, "European Philhellenism itself, insofar as it constructed a Hellenic world exclusively for its own consumption, was, historically speaking, an immanently anti-Hellenic expression” (151), Hemans in "Bride" seeks to rectify this problem of philhellenism by encouraging readers to look beyond ancient idylls to contemporary Greece's political woes. In fact, Hemans had in her earlier poem "The Voice of Scio" (published in The New Monthly Magazine in 1823) implored her readers to pay attention to the "Voice of Scio's isle" (1) which comes "From ruin'd hearths, from burning fanes, / From kindred blood on yon red plains, / From desolated homes" (30-32). In "The Voice of Scio," Hemans encourages her readers to recognize the national tragedy Greeks suffer as a result of seeking independence, a point that is also pertinent to readings of "Bride,"

\footnotetext{
${ }^{27}$ Cf. Lord Byron's Don Juan 3.86, wherein a trimmer poet tells the Greeks to "Fill high the cup with Samian wine! / Leave battles to the Turkish hordes, / And shed the blood of Scio's vine!" (738-40) only to change his mind and declare, "A land of slaves shall ne'er be mine / Dash down yon cup of Samian wine!" (783-84). Although Byron in Don Juan mocks the fact that the trimmer poet will express any kind of poetic sentiment for the right amount of money, his sentiments expressed here seem to align with Byron's. Interestingly, Hemans's narrator's call to the Greeks to "Fling down the goblet, and draw the sword!" is ineffective. Instead, Eudora's blaze is the most potent force in the poem.
} 
wherein the pirate-horde murders almost all of Eudora's wedding party and makes her a captive on their ship (all taking place on the island of Chios, no less). If European philhellenes lionized Ancient Greece, they should also be concerned about the welfare of Modern Greeks, Hemans suggests.

More than this, though, Hemans's "Bride" suggests that Greece (coded female) is capable of autonomous action in response to its subjugation. In fact, I argue that Hemans has Eudora selfimmolate at the end of "Bride" in order to upend further readers' expectations about a passive female Greece and to puncture a male narrative of nationhood and war with an act of female heroism. As Hemans writes, "Man may not fetter, nor ocean tame / The might and wrath of the rushing flame!" (189-90). Indeed, even the narrator, who speculates "had ocean's breast / Rock'd e'en Eudora that hour to rest?" (179-80), is surprised by a "piercing cry" (181) and "sudden spire" (183) from the pirate ship, prompting the speaker to proclaim "Fire! 'tis fire!" (184). Eudora's self-immolation, though, while an act of national assertion that many liberal Europeans would have celebrated,_-“Her blood was the Greek's, and hath made her free!" (214), proclaims the speaker - is not meant to confirm philhellenic conceptualizations of a Modern Greece modelled after the "free" ancient past. Instead, Eudora's performance contributes further to Hemans's earlier deflation of idyllic constructions of Greece. While Hellas's Chorus and Reine Canziani were unable to deal with the philhellenic significations forced upon them (both implicitly and explicitly) by philhellenes, Eudora's act symbolizes a rejection of foreign conceptions about Greece and Greek women. As I argued earlier, Hemans's complication of Eudora's gender works alongside her debunking of a classicized Modern Greece. Therefore, I suggest that when Eudora appears with "a band / Blazing up high in her lifted hand! / And her veil flung back, and her free dark hair / Sway'd by the flames as they rock and flare" (203-6), 
this symbolizes not only an act of personal self-assertion in a patriarchal culture that sees her only as a commodity (bride to the Greeks, booty to the pirates) but also as a moment of national self-confirmation that forces English readers to question their own preconceived notions of Greek women and, thus, of Greece. When Hemans has her heroine remove her bridal outfit that had previously constrained her, she also exposes the fictitiousness of the idealized Greece she presented at the beginning of the poem. While Hemans would have encouraged her readers to support Greek liberation, she nonetheless refuses to have Eudora represent the version of Greek woman most familiar to English readers (passive, weak), or to have her protagonist conform to philhellenic conceptualizations of what a Greek should be. As Benjamin Kim argues, fire in "Bride" is "a force that is at once the expression of loyalty and expression of revolt" (125); Eudora's self-immolation, then, confirms philhellenes' vision of a Greece committed to freedom while it simultaneously rejects certain forms of foreign constructions of Greece. As Sharifah Aishah Osman argues about Eudora and other nationalist female heroines in Hemans's poetry, "[b]y defiantly embracing death, these women not only reclaim their dignity and individuality as human beings, but also affirm their devotion to the land by asserting their rights as citizens" (n.p.).

While Eudora's blaze is symbolically meaningful, it is nonetheless ineffective on a practical level, the entire pirate crew "plunging from stern and prow" (199) as the Greek woman lights the ship on fire. As Wolfson argues, "'the slave and his master alike' escape from the ship, while this bride 'stands the deck alone' (202), burning in a futile, if impressive, heroism" ("Hemans and the Romance of Byron" 166). I would suggest, however, that Eudora lights the ship on fire not primarily in order to kill her captors, but instead as an expression of her own desire to escape the limits placed on her selfhood - what Hemans would have recognized as 
being the imperial, patriarchal, and ideological systems that keep Eudora entrapped. ${ }^{28}$ Eudora has sparked her own "light to lesson ages" as a protest from Greek women who long for better treatment and as a demonstration of their patriotism. Moreover, Eudora's act controverts conceptions of Greece as passively female and confirms that Greeks (including women) are able to protect their own national interests. By the end of the poem, Eudora becomes really and truly the bride of the Greek isle by inscribing her identity into the land of her birth, a gesture that confounds masculinist conceptions of nationalism and rejects the overcharged significations European philhellenes placed upon Modern Greece and its people.

But it all comes at a cost: the abandonment of her feminine domestic identity and, thus, of her family and past. In the last lines of the poem, Eudora stands proudly on the ship with a torch in her hand, initially confident and self-assured in her decision to self-immolate. Her resolve is shaken, however, when she hears "a shriek from her mother" (217), who watches as her daughter burns alive. Jolted from her trance-like state, Eudora "spreads her pale arms in vain / To the form they must never infold again" (219-20) in an act that foregrounds Eudora's domestic identity at the exact moment she is asserting her female national identity. Although Susan Wolfson rightly argues that this scene, in which Eudora dies reaching out for her mother, demonstrates Hemans's insistence "on a continuity between domestic affection and political rebellion" ("Hemans and the Romance of Byron" 163), I would suggest that it also emphasizes the tension between the domestic and the political spheres. In order for Eudora to make her political statement, she must throw off her domestic identity (starting with her bridal outfit), an identity that ultimately connects to her family and, most pertinently here, her mother. For Eudora, there is no alternative

\footnotetext{
${ }^{28}$ In fact, Eudora effaces the object that allows the pirates to kill her wedding party and make her a captive in the first place: their ship. As Hemans writes of Eudora's fire: "It hath twined the mast like a glittering snake, / That coils up a tree from a dusty brake; / It hath touch'd the sails, and their canvass rolls / Away from its breath into shrivell'd scrolls; / It hath taken the flag's high place in the air" (191-95).
} 
and she must sacrifice her "domestic self" in order to make a public statement about the plight of Greece and its women.

Even though Eudora dies, readers of "Bride" are left with a final, sentimentalist motif of female compassion and compatriotism, a fleeting moment between mother and daughter that transcends the horrors of male warfare, even if that moment of domestic sympathy operates within a narrative of nationalist emancipation. ${ }^{29}$ Indeed, in her later poem "The Sisters of Scio" (first published in the Literary Souvenir, 1830), Hemans picks up on the national selfdetermination of "Bride" when she relates the story of two sisters whose entire family has been killed by the Ottomans. In a moment of self-resolve, one of the sisters tells the other

A breath of our free heavens and noble sires, A memory of our old victorious dead,These mantle me with power! and though their fires In a frail censer briefly may be shed, Yet shall they light us onward, side by side;

Have the wild birds, and have not we, a guide? (19-24)

Here, the female speaker tells her Sciote sister that they, women, must carry on the fight for liberation begun by their male ancestors, the "noble sires" and "old victorious dead" to whom the woman alludes. The poem ends with the Greek woman telling her sister "Cheer thee! thy sister's heart and faith are high; / Our path is one - with thee I live and die!" (29-30). For Hemans, women can and must take an active role in the fate of the nation, even if, as in "Bride" and "The Sisters of Scio," the political resolve of the women is self-destructive and compelled by nationalist sentiment. The actions that these Sciote women perform act as a promotion of a

\footnotetext{
${ }^{29}$ As Benjamin Kim argues of nationally-themed poems in Records of Woman: "Hemans never moves the critique [against the limitations of traditional women's roles] past national loyalties and prejudice; it is only through nationalism that we can get beyond it, and whether Hemans ever does so is open to question" (124).
} 
Modern Greek nationality determined by both the nation's men and women, in place of a European masculine classical tradition that sought to classicize the Modern Greek topos. And even if Eudora's performance ultimately operates at a micro-level and has no real material impact on the Greek war, her actions render Greece not as a helpless country, but instead as a nation capable of asserting itself in the face of external pressures both Ottoman and Western.

\section{Symbols of the Nation}

Hellas, Reine Canziani, and "Bride" offer narratives of victimized women who seek a personal liberation that, I have argued, is linked more broadly to Greece's national independence. Shelley, Godwin, and Hemans represent the plight of actual Greek women, but also use their gender as an analytical tool through which to think about the West's role in the Greek war. As Teresa De Lauretis argues,

The cultural conceptions of male and female as two complementary yet mutually exclusive categories into which all human beings are placed constitute within each culture a gender system, a symbolic system or system of meanings, that correlates sex to cultural contents according to social values and hierarchies. Although the meanings vary with each culture, a sex-gender system is always intimately interconnected with political and economic factors in each society. (5)

Lauretis's argument that societies transform biological sex into culturally-inflected gender identities and that "sex-gender" systems are linked to "political and economic factors" helps us to understand how Shelley, Godwin, and Hemans portray Greek women in order to comment upon European intervention in Greco-Ottoman affairs. Whether or not they are recognized as such, women are central to the conception and advancement of social, cultural, and political movements. 
In this chapter, I have focused on the ways in which three Romantic authors employed female characters to think about the difficulties associated with securing Greek liberation, the problems with philhellenism, and the falsity of idealized, classicized portrayals of Modern Greece, especially amidst Greco-Ottoman warfare. Although all three writers sometimes adhere to Western cultural stereotypes about women — passive, victimized—I have argued that the authors' portrayals are more important for how they challenge Western readings of Greece and, thus, resist and disrupt the cultural, racial, and gendered politics of the Greek war. In fact, while all three authors employ the common trope of the passive woman victimized by the licentious Easterner, they do so not merely to criticize Ottomans but to comment on the ways in which Europeans (and really, European men) overlook how Greek women suffer the consequences of nation-building processes. Shelley, Godwin, and Hemans all understood that Europeans during the Greek war used portrayals of Greek women to orientalize the East and, importantly, that the depiction of the "victimized Greek woman" was ultimately detrimental to Greek autonomy. If, as Anne McClintock argues, Western imperialists gained "power through control of colonized women" (3), Greek women were in a double bind as "colonized" subjects saved from the Ottomans who were in turn "colonized" by Europeans who sought to use them propagandistically in their own mission to reshape Europe and Greece.

Throughout this chapter, I have emphasized that ideas about women as "cultural symbols" and as "living people" converged in nineteenth-century artistic portrayals of a "female" Greece that inspired European support. However, even if Greek women became emblematic of their nation, they ultimately had no say in its creation. Historically, of course, this is the standard for many nationalist movements wherein "[w]omen are typically constructed as the symbolic 
bearers of the nation, but are denied any direct relation to national agency" (McClintock 354). ${ }^{30}$ As Shelley, Godwin, and Hemans demonstrate, men and women-European, Greek, Easterndid not experience revolution and nationalism in the same way and it was Greek women who often suffered greatly from war and the philhellenic urge to craft a Europeanized Greek nation. Whereas Owenson in Ida of Athens argued that Ida's knowledge of her ancient heritage could help her to bolster her national identity and inspire revolution, the three authors in this chapter depict women as having no such agency. Instead, Shelley, Godwin, and Hemans depict a fractured (phil)hellenism and skepticism about nationalist rhetoric that contradicts Owenson's more hopeful vision for women in the nation. Already in the 1820 s we witness reluctance about Romantic nationalisms and their ability to establish freer and more equal European nations, with the Greek war being for the three writers the perfect example of this problem.

Greek women during the war of independence were used in forging a Greek-European alliance, in establishing Greek nationalism, and in creating a pan-European "imagined community," but often with traumatic consequences for them. Shelley demonstrates this by showing how the Greek Chorus falls into despair after learning that modern warfare and ancient ideology cannot save them; Godwin reveals the shortcomings of Western intervention in Greece by illustrating how Reine's forced classical identity is oppressive and inhumane; and, even though there is no Western character to impose his will in Hemans's poem, the poet's layering of past and present in "Bride" acts as an implicit criticism of the ways in which Greek women like Eudora are idealized while the real dangers to them are overlooked. It is when the allegorical

\footnotetext{
${ }^{30}$ In Women-Nation-State (London: Macmillan, 1989), Nira Yuval-Davis and Floya Anthias delineate five major ways "in which women have tended to participate in ethnic and national processes and in relation to state practices. These are: (a) as biological reproducers of the members of national collectivities; (b) as reproducers of the boundaries of national groups (through restrictions on sexual or marital relations); (c) as active transmitters and producers of the national culture; (d) as symbolic signifiers of national difference; (e) as active participants in national struggles" (7).
} 
converges with the real that readers begin to understand that, although Greek women might be symbols of their nation, they also endure the repercussions of male-run politics, whether the politics are those of Greek, Ottoman, or European men.

European and Greek nationalisms are, according to the three writers, built upon the suffering of women. In the case of Greece, philhellenes created a Hellenized Greece by looking to the classical past, a past that is, as Shelley's Chorus reminds us with its recollection of the myths of Jason and Medea, Orpheus and Eurydice, and Odysseus and Calypso, violent and misogynistic. Ultimately, and reasonably, the three works do not provide readers with a solution for the women's precarious positions. Shelley's Chorus asks the past to "die or rest at last"; Reine becomes a memorial of Greek female suffering; and Eudora, while she does fight back against her fate in a symbolically impressive gesture of self-immolation, nevertheless dies. By the end of each of the works, it is clear that the message is not just about liberating the Greek nation, or Greek women, from the Ottomans (this is why the focus of each work is not on Ottoman oppression), but about freeing women from the masculinist political, cultural, and social systems that keep them oppressed in the first place. Certainly, the three writers understood that this would be no simple task, but telling the stories of these women was a powerful start for it allowed readers to understand the ways in which womanhood was deployed politically, culturally, and ideologically to the detriment of the female sex. 


\section{Chapter Four}

\section{All Roads Lead to Constantinople: Re-Historicizing Greek-British Relations in The Travellers and The Last Man}

\section{Introduction}

In the previous three chapters of this dissertation, I have examined the various ways in which British Romantic writers portrayed Modern Greece for an early nineteenth-century readership that was becoming more fully acquainted with an Ottoman-ruled territory and people that had for centuries been on the fringes of European political and historical consciousness. In so doing, I have discussed multiple social, political, and cultural concepts central to Romantic-era depictions of Modern Greece and emphasized the productive tensions present in, and among, Romanticperiod texts. In Chapter 1, I paired two pre-1821 novels, Sydney Owenson's Ida of Athens and Thomas Hope's Anastasius, to argue that these books represent two versions of Modern Greece, one oriented to the Western world and the other aligned with the Eastern world. In the early nineteenth century, Greece was largely considered a territory at the crossroads of East and West, with Romantic-era writers debating Greece's "Western" and "Eastern" qualities and what the country's unique geopolitical position meant for Greek people's national future. In Ida, Owenson strives to convince readers that Modern Greeks like her titular heroine retain many of the traits of their ancient progenitors and should, with European assistance, become an independent nation assimilated into a Western sphere of influence. On the other hand, Hope, in Anastasius, demonstrates that Greeks are culturally and socially very different from their ancient forbears and indeed better adapted to life in the Ottoman East. At points, however, the two texts betray their fundamental ideological positions-i.e. when Ida rejects her high society life in Britain after realizing it stifles her nationalistic ambitions, or when Anastasius discovers that his ability to adopt multiple identities in Ottoman society actually makes him better suited for life in the 
West — revealing the problems inherent in defining Greece as either Western or Eastern and, indeed, by appealing to East/West binaries at all.

In Childe Harold's Pilgrimage, Lord Byron invites his readers to move beyond such binaries when discussing the Modern Greeks. As he writes in "Note II" of Childe Harold's Pilgrimage: "Instead of considering what they have been, and speculating on what they may be, let us look at them as they are" $\left(174 ; 2^{\text {nd }}\right.$ ed.). By providing a balanced observation of Modern Greek (and Ottoman) character, highlighting Greek publishing and literary efforts of the last two centuries, and discussing the merits of the Romaic language, Byron successfully defends Greeks against the Edinburgh Review's charge that Modern Greece's supposed lack of cultural production represents Greek people's unpreparedness for national independence. By “'look[ing] at them as they are," Byron depicts a culturally vibrant Modern Greece deserving of freedom from the Ottoman Empire, even if he maintains that his observations avoid "speculating on what they be." More than any other writer of his generation, Byron was responsible for thrusting Greece into the consciousness of nineteenth-century Europeans and for convincing them to adopt Greeks into the Western sphere, especially following his death in Messolonghi in April 1824 while he was preparing to go to battle on behalf of the Greeks in the war of independence.

The kind of philhellenism that Byron inspired (though not necessarily always endorsed) demonstrates how cosmopolitan, national, and colonial processes worked together to construct a Greece that adhered to Europe's idealizations of the ancient past, even if Greeks themselves were not completely prepared for this characterization of their nation, which clashed with their own self-identifications. As Yannis Hamilakis argues, Europe "invented modern Greece through the device of Western Hellenism, and ... endowed the new institution with the colonial narratives of linear continuity, of boundedness, of racial and cultural hierarchies" (123). In particular, 
philhellenes throughout Europe encouraged their fellow countrymen and women to regard the Modern Greeks as descendants of Ancient Greeks, as they recognized that this cultural alignment provided Greeks with the best chance of securing European intervention in the Greco-Ottoman war of the 1820s. However, as I discussed in Chapter 3, philhellenism itself was not an innocent ideology but, rather, one that had its own political imperatives and orientalizing tendencies. Percy Bysshe Shelley, Catherine Grace Godwin, and Felicia Hemans, writers of different political persuasions, emphasized how European philhellenism not only helped to secure Greek liberation but also to incite a violent form of Greek nationalism, efface indigenous Greek identity, and even encourage Western colonialism in Greece.

Even before Greece officially became a modern independent state in 1832, European philhellenes promoted a vision of the Greek War of Independence that made it a global rather than merely national affair, even if all Greeks themselves were not fully aware of, or prepared for, this international development. As Stathis Gourgouris explains,

The problematic of modernity thus enveloped Greece before the explicit intervention of the discourse of modernization that characterized the initial institutional actions of the new State. What began as an internal Ottoman affair, an insurrection seeking ethnic autonomy riding on an initially rather nebulous ideology, was at once elevated to an international affair. Given the specific historical parameters of the period, to say that the Greek uprising became internationalized is tantamount to saying that it was Europeanized-that it became an affair internal to the wider geopolitical configuration of Europe, which was itself at the time being constantly redrawn. (73) 
Philhellenic intervention in the Greek War of Independence reinforces Evan Gottlieb's argument that the Romantic Age represents the emergence of the "global imaginary" (3). Importantly, Gottlieb's emphasis on the interconnectedness between globalization—which he defines as "a set of interlinked economic, political, technological, and socio-cultural transformations that has been developing for several centuries" (5) — and modern state formation helps to illuminate how Europe's intervention in the Greek War of Independence led to a Greek national sovereignty that strengthened its connection to Europe and the West, but which also forced Greeks to adopt a new national Hellenic identity that clashed with their indigenous Romaic and Orthodox identities. With the assistance of Europe — namely Britain, France, and Russia—the Muslim-ruled Greece of the last four centuries (since 1453, when Sultan Mehmed II defeated the Byzantine Emperor Constantine XI Palaeologos) was in 1832 officially recognized as an independent state from the Ottoman Empire and became the Modern Greek nation that exists to this day, a nation that has from its foundation struggled to negotiate European expectations about how it should express its Modern, Western, and Greek identities.

In Chapter 4, I examine two novels written just prior to Britain, France, and Russia's momentous military intervention in the Greek War of Independence at Navarino (Pylos, Greece) on 20 October 1827, wherein a joint British, French, and Russian fleet overpowered the Ottoman Empire's navy, creating the opportunity for Greeks to declare their independence from the Ottoman Empire. ${ }^{1}$ The two novels I discuss, Tertius Kendrick's The Travellers (1825) and Mary Shelley's The Last Man (1826), both feature British characters—-Sidney Melcombe in The Travellers and Lord Raymond in The Last Man — who journey to Greece in order to fight with the Greeks against the Ottomans. Although neither novel is set in the 1820s, both narratives

\footnotetext{
${ }^{1}$ For an account of this mission as the first instance of a pacific blockade which changed international law, see Will Smiley, "War without War: The Battle of Navarino, the Ottoman Empire, and the Pacific Blockade," Journal of the History of International Law 18 (2016): 42-69.
} 
implicitly ask readers to consider what it would entail for contemporary Britain to assist Greece, for Greece to become a westernized nation, and for Britain and Greece to develop closer transnational relations. In Romantic 'Anglo-Italians,' Maria Schoina contends that British Romantic writers' representations of Italy demonstrate how "[f]ictional literature and travel writing are a good testimony to the expansion of the geo-cultural vistas of the time" (33). Schoina's argument, I suggest, is equally pertinent to my discussion of British Romantic writing about Greece, and particularly relevant to my examination of The Travellers and The Last Man, especially as Kendrick's and Shelley's novels, published in 1825 and 1826 respectively, represent British-Greek military alliance in light of Britain's (and Europe's) seeming inaction on behalf of the Greeks during the war of independence.

In order to examine Greek-British relations of the early nineteenth century, both novelists offer personalized narratives that only implicitly comment on the 1820s Greek War of Independence and which imagine liberation movements of the past (Kendrick) and of the future (Shelley), a decision by the authors which invites their readers to consider how past and future inform the present day Greek war. Although Shelley's method of historical distancing is arguably more complicated and radical (she projects the future rather than reinterpreting the past), I argue that both authors employed a narrative technique popularized by such Romanticera writers as Maria Edgeworth and Walter Scott, whose literary histories were widely read and celebrated during the period. As Mark Phillips claims:

$[T]$ he vogue for literary histories in this period owes much to a desire for a closer affective engagement with the past. Though other motives were certainly present, readers were attracted to narratives that mediated the past through literary texts and literary lives. Indeed in an epoch when historical sensibilities were 
increasingly drawn to representations of inward experience, the writings of poets and playwrights provided the best entry into a realm which was otherwise difficult to document or explore. (17)

According to Phillips, eighteenth and nineteenth century readers unsatisfied with "the excessive rationalism of the Enlightenment" (80) increasingly looked to literary histories rather than history proper to understand historical events, as literature granted readers "privileged access to private experience" (141) and thus allowed them to affectively engage with specific historical moments. "What literary history offered," writes Phillips, "was an appeal to sensibilities more immediately engaged with thoughts and feelings than with the traditional narrative of actionhistory redistanced for a sentimental age" (141).

By providing fictionalized accounts of actual (or in Shelley's case, projected) historical moments, Kendrick and Shelley invite readers to affectively engage with Greece's bid for independence, even if they could not understand or conceptualize completely the political ramifications of the $1820 \mathrm{~s}$ war. Importantly, the two novels use historical imagination to portray a Greek-British transnational relationship, representing the two countries as having shared cultural, historical, and geopolitical destinies during a period when Britain's lack of intervention in Greco-Ottoman warfare contradicted this view. Indeed, by portraying Greece's past (The Travellers) and future (The Last Man), the two novels, whether intentionally or not, partake in the larger philhellenic mission of providing Greece with a national narrative crucial to its independence and integration into European society. As Antonis Liakos writes, "[t]he construction of the national narrative," a process which I argue both Kendrick and Shelley take part in, "restructures the experience of time, attributing a new significance to it and presenting the nation as an active historical agent that, through the narration, acquires a new historical 
identity" (202). By narrativizing Greece's past, writers created a sense of national continuity (past, present, and anticipated future) vital to the foundation of national identities. Ultimately, as Liakos states, "[w] hat is at stake is not simply the appropriation of a part of a historical experience, but the construction, in the present, of a discourse that reproduces the past and transforms it into national time" (204). By imagining British characters as participants in historical processes central to the creation of Greek national identity, Kendrick's and Shelley's narratives demonstrate how transcultural interactions contributed to the making of modern national histories and identities.

If, as Gourgouris argues, authors make, "through writing, the history of the nation real while making the reality of the nation historical" (263), how and why do Kendrick and Shelley participate in this process in regards to Greece? If historical narration and imagination were required to construct the Greek nation, in what ways, and for what reasons, do the two authors deploy the techniques of historical distance to contribute to this process? Using the imaginative freedoms available to writers of literary histories (as opposed to more traditional forms of history), Kendrick and Shelley both create Greek national narratives wherein Britain plays a pivotal role, although, as I discuss in the sections that follow, the authors differ significantly about what British intervention in Greek affairs entails for both nations. Kendrick opts to look to the past—specifically, the Orlov Revolt of 1770, a Greek uprising in the Peloponnese which was a precursor to the 1821 Greek War of Independence - in creating a story of a friendship between the British Sidney Melcombe and Greek Alexis Condili. In The Travellers, Sidney is convinced by Alexis to travel to Greece to support his country's bid for independence and though, true to historic fact, the Greeks are defeated by Ottoman forces, Kendrick suggests that this revolt has served to strengthen future Greek-British relations (as symbolized by Sidney's marriage to 
Alexis's sister Ianthe). Because of Sidney's symbolic investment in the 1770 revolt, Kendrick suggests, the Britain of the 1820s (for which he writes) should be more inclined to assist the Greeks in their present day struggle for freedom.

Shelley's The Last Man, on the other hand, portrays a relationship between Britain and Greece that ultimately causes the Plague which kills off the entire world, save Lionel Verney, the last man of the novel's title. For Shelley, Greek independence itself is a positive development; problematic for her, though, is the coincidence between Britain's imperialist policy and Greece's territorial expansionist desires, the latter a later nineteenth-century historical development Shelley predicts with shocking prescience. ${ }^{2}$ By projecting forward in time, Shelley can anticipate how British support for Greece might unfold and offer her narrative as a warning against a form of British-Greek transcultural relations that depends on aggressive colonialist policies by both countries. Unlike Kendrick's narrative, in which the past (almost) seamlessly sets the path for Britain's present-day support of Greece, futurity in Shelley's novel complicates how early nineteenth-century Britons were to regard the Greek war.

Finally, these brief synopses of The Travellers and The Last Man should not be regarded as suggesting that Kendrick endorses the 1821 Greek War of Independence while Shelley does not. Rather, as becomes clearer in my analysis of each text, I suggest Kendrick supports an internationalized view of the Greek war wherein Britain plays a vital role in foreign affairs, while Shelley critiques what she considers to be Britain's colonialist intervention in Greece. During a

\footnotetext{
${ }^{2}$ Megali Idea ("Great Idea") was a nationalistic irredentist concept formally introduced in 1844 by Prime Minister Ioannis Kolettis. Advocates of Megali Idea, a policy that dominated Greek foreign policy throughout the nineteenth and early twentieth centuries, supported a Greek territorial expansion that would see Greece establish not only its classical lands, but those territories that were part of the Byzantine Empire too. Importantly, Constantinople (Istanbul) - the seat of the Byzantine emperors, but now ruled by the Ottomans - would be established as the capital of Greece. Hopes for a successful Megali Idea were crushed when Turkey defeated the Greeks in the Greco-Turkish War of 1919-22. For more on Megali Idea, see Marjorie Housepian, Smyrna 1922: The Destruction of a City, London: Faber and Faber, 1972; P. Nikiforos Diamandouros, Thalia Dragonas and Çağlar Keyder (eds.), Spatial Conceptions of the Nation: Modernizing Geographies in Greece and Turkey, London: Tauris, 2010; and, in Greek,

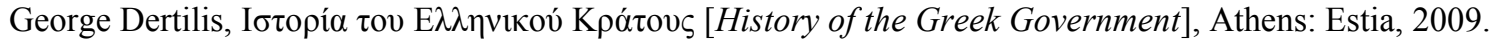


period when Britain was becoming a more prominent power on the international stage, Kendrick and Shelley used the Greek war to scrutinize Britain's Mediterranean foreign policy and the role the country would play in an independent Greece. If the Romantic era was the age of the "global imaginary" wherein "Britons needed to learn to see themselves as members of a nation whose geopolitical destiny was intimately bound up with those of the rest of the world" (Gottlieb 148), Kendrick and Shelley's novels interrogate the consequences of Britain's role in this increasingly global world and examine the extent to which their country's modern political relations could truly "be conceived as cooperative and egalitarian rather than competitive and hierarchical" (Gottlieb 148).

\section{"Here Lyeth the Body of Theodore Palaeologus": Greece, Britain, and the Byzantine Past}

Kendrick visited the Ionian Islands, most of which were under British control, in the 1810s and likely based The Travellers upon his experiences with Greeks there. The novel replicates the formal elements of the historical novel, popularized by Walter Scott with his 1814 publication Waverley. The Travellers, like many historical novels, presents a tale about the past which features an English protagonist who travels to another country and begins a cross-cultural romance. Vitally, in The Travellers, as with most historical novels, the Englishman's journey represents the ways in which transcultural convergences impact and alter national identities. As Katie Trumpener explains, "[t]he historical novel ... finds its focus in the way one developmental stage collapses to make room for the next and cultures are transformed under the pressure of historical events" (142). As I discuss, Kendrick's novel, which is set in the 1770s, uses a specific event from recent Greek history (its first revolt against the Ottoman Empire) to encourage his own country to aid Greeks in their contemporary (1820s) revolution. For 
Kendrick, an imagined history about Greece's past that includes a British protagonist has the potential to shape a new international relationship between Greece and Britain.

The Travellers opens on the scene of a masquerade ball hosted by King Christian of Denmark at King's Theatre in the Haymarket in 1769. One of the many guests at the banquet is the novel's British protagonist, Sidney Melcombe, who has come "attired in the gorgeous costume of a Turkish Pacha" (1.11). Sidney, admired by the banquet's other attendees who "expressed their approbation at his correct personification of an eastern despot" (1.12), is initially in good spirits, until he is approached by a man "in the dress of a Levantine Greek" (1.16) who chastises him for performing the part of a tyrant. In his brief discussion with Sidney, the Levantine Greek (who we later learn is Alexis Condili, not in costume as Sidney initially believes) tells him that he has travelled to Britain because the British are supposedly the "ready defenders of Liberty" (1.20), though he deems Sidney himself (and perhaps implicitly, Britain) "too young" (1.22) to help Greece, before hastily leaving the banquet with a promise to see Sidney again.

The Travellers begins with this fictionalized encounter between Sidney and Alexis within a factual historical moment in order to explicitly criticize the British for remaining inactive in Greek affairs. Although "no country possessed more riches than England, or was so liberal in applying them for the benefit of others" (1.5), the country's wealth does not go toward benefiting those who struggle under despotic governance, but instead toward paying for jewelry and clothing to flaunt at superfluous events like King Christian's masquerade ball. More than this, Sidney's "playing the Turk" is revealed to be a crude and uncritical objectification of Greek people's subjugation (not only by Sidney, but also by the banquet attendees who applaud his choice of costume) when Alexis confronts the British man about his choice of dress. The opening 
scene, then, offers readers a glimpse of Greco-Ottoman politics - and Britain's role in themthat are played out, both literally and figuratively, on a British stage. Indeed, Kendrick emphasizes the politicized nature of this opening scene when, immediately following Alexis's departure from the banquet, he has Sidney remember reading in the St. James Chronicle that Britain will, "respecting the revolution in Modern Greece ... maintain a strict neutrality" (1.25), a position that stands in stark contrast to Catherine the Great's declaration that Russia will assist the Greeks. Here, Kendrick blends past historical fact with present (1820s) political concerns to rouse his readers. It is true that Russia offered Greeks support in their bid for independence during the Orlov Revolt of the 1770s (before ultimately abandoning them after signing a treaty with the Ottomans) and Kendrick uses this historical moment to remind his readers of Russia's contemporary (1820s) participation in Greco-Ottoman affairs, an involvement which ultimately threatens Britain's monopoly over the Mediterranean region. ${ }^{3}$ Russia's steady rise to power over the late eighteenth and early nineteenth centuries was a cause for alarm for many Europeans and by contrasting Russia's engagement in Greek affairs with Britain's inaction on behalf of the Greeks, Kendrick warns that his country is missing out on the opportunity to assert its global influence and dominance. ${ }^{4}$

Kendrick suggests that early nineteenth-century Britain would take a greater interest in Greeks affairs if only Britons informed themselves about their shared heritage with the Greeks.

\footnotetext{
${ }^{3}$ Indeed, the 1774 Treaty of Küçük Kaynarca between the Ottoman Empire and Russia extended many powers to Russia. Importantly, the Treaty gave Russians the right to protect the Ottoman Empire's Orthodox Christian subjects, which included the Greeks. Writers such as Sydney Owenson-who mentions Russian intervention in Greco-Ottoman warfare - and Kendrick understood that Russia used its shared Orthodoxy with the Greeks to make territorial and political gains in the Mediterranean region. For more about the Treaty of Küçük Kaynarca, see chapters two and three of Roderic H. Davison, Essays in Ottoman and Turkish History, 1774-1923: The Impact of the West, Austin: University of Texas Press, 1990.

${ }^{4}$ See for example the Westminster Review's 1824 review of two foreign books about Russia that begins "[t]here was a country a century ago which excited neither interest, nor jealousy, nor anxiety" before stating "[b]ut things are altered now; and Russia, barbarous still, has aspired to, and has obtained, a dictatorship over the states of Europe" (80). See "Art V. Parallèle de la Puissance Anglaise et Russe relativement á l'Europe." Westminster Review 1.1 (1824): 80-101.
} 
Surprisingly, Kendrick does not appeal to the ancient past to forge a connection between Britons and Greeks, but instead looks to the Byzantine Empire to do so. Following his banquet meeting with Alexis, Sidney sees the Greek man visiting the church on his estate in Landulph (in Cornwall) and learns after speaking to him that he is visiting the burial spot of his ancestor Theodore Palaeologus. Kendrick provides readers with an (abbreviated) dictation of Palaeologus's real-life grave inscription:

Here lyeth the body of Theodore Palaeologus, of Pesaro in Italy; descended from the imperial line of the last Christian Emperor of Greece; being the sonne of Cammillio, the sonne of Prosper, the sonne of Theodore, the sonne of John, the sonne of Thomas, the second brother of Constantine Palaeologus, that rayned in Constantinople, until subdewed by the Turks. Who departed this life at Clyfton, the $21^{\text {st }} \operatorname{Jan}^{\mathrm{y}} 1636 .(65)$

This is a crucial moment in The Travellers. In this scene, Kendrick provides his readers with material proof of Greece and Britain's longstanding relationship by memorializing a relative of the Byzantine Empire's final emperor (Constantine XI, d.1453) who lived in England in the early seventeenth century and whose burial plaque can, to this day, be found in Cornwall (Kalymniou n.p.). Theodore Palaeologus's gravesite reminds the British that Greeks have a centuries-long historical past that links them both to the West and to Britain and which, importantly, serves as a counterbalance to Russia's shared Orthodoxy with the Greeks.

Still more, on an ideological level, Theodore Palaeologus's grave represents Greece's own Western-oriented "middle age" that makes the country's past both more relatable and intimately felt for British readers: 
The inscription of Byzantium into the ancestral narrative stemmed from

Philhellenism's demands, for Greek modernity had to demonstrate not only its genealogical link to the West's cultural origins, but also its link to an equivalent, perfectly European, middle - the missing link, so to speak, to whose excavation and elaboration nineteenth-century history is predominantly devoted. ${ }^{5}$

(Gourgouris 259)

Byzantium, "the missing link" between Ancient and Modern Greece, provides Kendrick with an ideal historical epoch wherein to connect Britain with Greece, and vice versa. When Kendrick has the two men bond at Theodore Palaeologus's Cornwall burial site, he invites his readers to acknowledge the connection between the current British Empire and the past Byzantine Empire, the longest lasting continuation of the Roman Empire (the Byzantines called themselves "Romans"), which many Britons considered to be their own cultural legacy. As Jonathan Sachs writes, “[j] ust as Rome was seen to borrow, extend, and ultimately surpass Greek ideals in the production of a dominant empire, so eighteenth-century British thinkers began to conceive of their emergent empire as the apotheosis and extension of Roman ideals" (34). ${ }^{6}$ For Kendrick,

\footnotetext{
${ }^{5}$ Because of the sixteenth-century humanist Hieronymus Wolf, we today call the Eastern Roman Empire (c.3301453) the Byzantine Empire. Wolf used the name Byzantium to denote the Roman Empire of the Middle Ages in his collection of primary sources originating from this polity, entitled Corpus Historiae Byzantinae. The name of the empire derives from Constantinople's Ancient Greek name Byzantion, of which Byzantium is the Latin rendering. The rulers and subjects/citizens of the Eastern Roman Empire would have thought of themselves as Romans, a point that is crucial as this situated the Greeks as direct continuators of Classical Roman civilization, up until 1453 when the Eastern Roman Empire was conquered by the Ottoman Empire. Those nations in Europe that developed as a result of the fall of the Western Roman Empire and the great migration that followed in the $5^{\text {th }}$ century had no direct links to the Roman Empire, but instead relied on the empire's legacy in order to shape their own statecraft. By the 15 th century, these new European states began to appropriate the Roman legacy and envision themselves as exclusively Western. For this very reason, Wolf and scholars like him insisted on the name Byzantium in order to deprive the Greek "East" of its Roman identity that was preserved for the "West" since the Renaissance. Despite what nineteenth century geopolitical borders would have people believe, the Byzantine Empire in fact regarded itself as the dominant Mediterranean and even Eurasian power for over one millennium. For more about the historical naming of the Byzantine Empire and matters of Romanness in Byzantium, see John H. Rosser, The A to $Z$ of Byzantium, Lanham, MD: Scarecrow Press, 2006; and Anthony Kaldellis, Hellenism in Byzantium, Cambridge: Cambridge University Press, 2007.

${ }^{6}$ For a full account of the British Romantic period's preoccupation with Rome, see Jonathan Sachs, Romantic Antiquity: Rome in the British Imagination, 1789-1832, Oxford: Oxford University Press, 2010. In discussing
} 
early nineteenth-century Greek-British relations can be built upon the current British Empire's reverence for a former Greek (and thus Romanized and Christian) empire, a politics that Mary Shelley explicitly critiques in The Last Man. By focusing on Alexis's Byzantine heritage, Kendrick invites readers to recalibrate their historical perspectives. Instead of looking to Ancient Greece to generate support for the contemporary Greek liberation movement, Kendrick suggests that the Byzantine Empire offers an even closer Greek past through which to consolidate the transnational bond between Greece and Britain.

Indeed, after Alexis tells Sidney that he is "the lineal descendant of this ancient and royal race" (1.66), Sidney informs him that "[t]he attention of the people has been seriously directed to your nation, in consequence of the news received of your revolution" (1.67) and that he is inspired to travel to Greece with Alexis in order to fight on behalf of Greek independence. By having Sidney journey to Greece, Kendrick confirms the historical intimacy between British and Greek people (if not necessarily yet between their governments) that he has been reinforcing up to this point in the novel. In fact, after informing his readers that Sidney will travel to Greece to help the Greeks "recover their birthright from the hands of their oppressors" (1.86), Kendrick abruptly breaks off the narrative in order to provide his readers with an historical retrospective of the 1770s war from his 1820 s perspective.

Kendrick tells his readers that "though it appears that no affectual and sincere aid has ever been granted by the European powers to the Modern Greeks, yet this fact by no means ought to be taken as unwillingness on the part of the people to assist in the regeneration of the country, for it too often occurs that the sentiments of a court are opposite to those of the community at large" (1.92-93). He also explains that the Russians deceived the Greeks into

Rome's relevance for the British Empire, Sachs writes that "Rome could represent a powerful model of European culture, of literary authority, of liberty and civic participation, of imperium sine fine (empire without end) - but also of decline and ruin" (18). 
believing they could obtain independence only so they could use them as collateral in order to negotiate a better territorial deal for themselves with the Ottomans: "Russian agents, infected every class of people with the same disordered notion of independence; and from that instance the people implicitly believed in the promises of a power which ultimately gave them up to the cruelty of the Porte" (1.95). Reading this authorial intervention that follows the previous chapter wherein Alexis asks for "the attention of civilized Europe" (1.73) and informs Sidney that he and his fellow delegates believe Britain best suited to aid Greece, it is apparent that Kendrick's objective is to align Britain with Greece — and, importantly, to do so to prevent Russian dominance in the Mediterranean. In fact, Britain's intervention in the Greek War of Independence was privately endorsed by many British philhellenes, including foreign secretary George Canning, who envisioned "a 'free' Greece as an engine of British liberalism and a hopedfor barrier to Russian expansion" (Holland and Markides 1). Even though the sentiments of the majority of the "court" do not yet explicitly correspond with those of the British "community at large," Sidney's blossoming friendship with Alexis, and his willingness to partake in a foreign war (in the 1770s), serve as a model for British people (in the 1820s) to take concrete action on behalf of the Greeks. By moving from past to present to past again (when he resumes his narrative), Kendrick forces his readers to consider the parallels between their current historical moment and that of the 1770s Europe the author depicts.

When readers are reacquainted with Sidney and Alexis following Kendrick's historical interlude, the two men are on the island of Paros in Greece where Sidney is learning Greek and Italian from his friend, a sign of his commitment to cultural assimilation in his new environment. Readers are introduced to a host of Greek characters at this point in the narrative, but one person in particular is important for Kendrick's portrayal of a strong and persistent British-Greek 
relationship: Ianthe, Alexis's sister (and Sidney's wife-to-be). Ianthe first appears in The

Travellers when Sidney sees her "engaged in the quiet perusal of a book" (1.180). The narrator notes that "Ianthe Condili was possessed of a masculine mind; not of that kind, however, which imparts a similar tone to personal manners" (1.181-82). Aware of the controversies surrounding female reading and education in early nineteenth-century Britain, Kendrick emphasizes that Ianthe's intelligence does not compromise her femininity: her "masculine mind," cultivated through her reading, does not affect her "personal manners."7 Instead, Ianthe's "revolutionary spirit" (1.183) — a product of her "masculine mind" — is a positive attribute because it is tempered by her class and educational backgrounds. As Kendrick writes, "[h]er education was obtained in Italy; and a constant association with the best society that Venice could afford, had imparted that refinement and elegance to her manners which made her the superior being that she was" (1.182). Kendrick portrays Ianthe as a cosmopolitan Greek woman who has been educated in a region more closely associated with Europe, a fact that - troublingly as I show later in this chapter-detaches Ianthe from Greece and aligns her with the West.

Ianthe's ability to read discerningly is a sign for Kendrick's readers that she is the kind of Greek woman with whom it is worth associating. In fact, when Sidney interrogates Ianthe about the book that she is reading (Pietro Mesastasio's Attilo Regolo), the Greek woman reveals that she is not a naïve reader who passively absorbs the texts she reads, but who instead thinks critically about them. ${ }^{8}$ Ianthe understands that Sidney might think Attilo Regolo "of a nature too

\footnotetext{
${ }^{7}$ In Women's Reading in Britain 1750-1835: A Dangerous Recreation, Jacqueline Pearson examines the increased female readership of the eighteenth- and nineteenth-centuries in Britain and the fears that arose about reading's corrupting influence on women. Although certain types of reading were more encouraged than others-i.e. conduct books - “[t]he argument about women's reading centred on the novel, with novel-reading one of the most contested areas in cultural debate" (196).

${ }^{8}$ Pietro Mesastasio's eighteenth-century opera, Attilo Regolo, relates the story of the third-century B.C. Roman statesman Marco Regulus Pololus's decision to willingly accept imprisonment by the Carthaginians for the benefit of his city (Rome). Although his fellow Romans try to prevent Regulus from surrendering to the Carthaginians, the
} 
political to interest the feelings of a young woman" (1.198), but explains that the Roman senator Regulus's self-sacrifice on behalf of his city has been useful in teaching her "the patriotism inherent to a generous heart, in behalf of the moral liberty and freedom which every country must possess ere its people can hope to consolidate their security and happiness" (1.199). Sidney is struck by the Greek woman's intelligence and her ability to understand literary texts: "It is difficult to describe the situation that Sidney was placed in, while listening to the words spoken by Ianthe. He almost at one time thought himself in England; so contradictory did it appear to him that he was placed then by the side of a woman whose language and manners were so strikingly at variance with the notion he had gathered of the Grecian females" (1.199-200). Because she is a discriminatory reader, Ianthe exceeds her ethnic standing and can, thus, potentially become integrated into British society as the ideal wife. ${ }^{9}$ In fact, I argue that by introducing Ianthe into his novel, Kendrick begins the process of transmuting Sidney and Alexis's friendship into a more permanent and long lasting romantic relationship between Sidney and Ianthe, a move that works to strengthen the British-Greek alliance his novel depicts. It is not a coincidence, I suggest, that Kendrick informs us of Ianthe that "[i]n features she resembled Alexis; but these were, at the same time, delicately feminine" (1.180).

\footnotetext{
Roman statesman believes it is his civic duty to do so. Regulus's story represents a classic example of the virtuous citizen putting the well-being of his people and country over his personal safety.

${ }^{9}$ Many early nineteenth-century writers discussed the importance of women being discriminatory rather than passive readers. For example, in Strictures on the Modern System of Female Education, Hannah More argues that, while sentimental fiction and French philosophical works corrupt female readers, a proper education regimen that includes religious materials and conduct manuals can prepare women to be faithful and beneficial wives. Perhaps unsurprisingly, Ianthe later in the novel is found by Sidney "engaged in the calm perusal of a religious work" (3.135). In Memoirs of Modern Philosophers, Elizabeth Hamilton presents a less conservative account of female reading by featuring Harriet Orwell as one of her protagonists. Though Harriet has a more restricted reading regimen as compared to the novel's other female characters who read sentimental fiction and "new philosophy" (like Julia Delmond, whose father's failure to restrict her reading materials leads to her tragic death), she is still able to read materials typically thought to be for men, such as Hume's History of England. As Julie Murray argues, "Harriet is not what some critics call a 'conventional heroine,' if this term simply means traditional" (687). Instead, "Harriet models the kind of renovated feminine domesticity that pits good household management, emerging middle-class industry and efficiency, and evangelical piety against superannuated, enervated forms of female decadence" (687). Indeed, though I do not discuss her in this chapter, Kendrick does provide Ianthe with a female foil in his novel: the Contessina Maruzzini, the petty, vindictive daughter of a Venetian count whom Sidney rejects in favour of Ianthe.
} 
Ianthe's romance with Sidney does not always seem inevitable, though, and at points in the novel the Greek woman expresses a strong will and independence that runs counter to the dictates of proper female etiquette that would qualify her for British wifedom, just like the titular heroine of Owenson's Ida of Athens. For example, when the battle between Greeks and Ottomans is about to commence, Alexis tells Sidney his plan to send his sister to a nunnery in Venice to ensure her safety. However, when he informs Ianthe of his intentions, she "reject[s] the proposal in toto" (2.135) before declaring to her brother that she will join the men in their journey to the Morea (Peloponnese) as "her heart was wedded to the fate of her country and her feelings led her to desire that she might be near the spot on which it was to be decided" (2.136). Later still, when it is clear that the Greeks will lose to the Ottomans after their Russian allies have received word from Catherine the Great to retreat (following her signing of a peace treaty with the Ottomans), Ianthe resolves to remain at the site of the battle, even though it likely entails her death. Despite Sidney's admonition to Ianthe that she is practicing a "mistaken heroism" (3.139) and his imploration for her "to abandon your fatal purpose" (3.139), the Greek woman remains committed to her mission, offering Sidney a pointed response that forces him (and Kendrick's readers) to reflect upon his privileged position as a Briton:

"I cannot;--I will not. And now, Sidney," said Ianthe, faltering in her turn, "let me offer you some advice. You have embarked in a sea of woe and peril; but you can easily escape. Let me therefore counsel you to return to a safer land while it is in your power. There are females in your native country more deserving of your attention than myself. You can live happily in the circle of your own family, and remain undisturbed in the peaceful enjoyment of that bliss known only in climates farther north than Greece.” (3.139-40) 
Ianthe's belief that life is worthless "unless we devote it to the service of our country" (3.180), rejection of the domestic "peaceful enjoyment" that life with Sidney would offer her, and insistence in taking part in the war, all serve to masculinize the Greek woman and make her a potentially problematic heroine for readers who might not be able to empathize with such a patriotic and assertive female character. Subduing the foreign Greek woman,- - which Owenson does not allow to happen to her heroine Ida, and which Mary Shelley in The Last Man demonstrates is perilous - then, is a necessary prerequisite for the future British-Greek alliance that Kendrick envisions.

Just as European countries like Britain and France dictated "ideological control of the meanings of antiquity" (Van Steen 26), Kendrick in The Travellers imposes control over Ianthe for the benefit of his country. Although Ianthe insists upon dying for the Greek cause, she ultimately is made subsumable to British society when her brother Alexis, on his death bed, joins her hand with Sidney's, thus demonstrating his approval of their relationship. In this moment, the two men collude to temper (but not quell) Ianthe's patriotism so that it is made acceptable for British readers. The process of converting Ianthe's potentially radical nationalism into a more palpable patriotism that is practiced in moderation and in accordance with what the British consider good female manners is finalized when Sidney and Ianthe move to England and marry following the failed Greek rebellion and Alexis's death. At their home in Landulph, Sidney brings a melancholic Ianthe to visit the tomb of her ancestor Theodore Palaeologus where, in addition to Theodore's gravestone, Ianthe discovers another: "Here lie the ashes of Alexis Constantine Condili, the last male descendant of the imperial line of the Palaeologi, who fell by the hand of treachery at Misitra, while defending the interests of his country. Reader, - If thou hast a soul that can admire what is noble in man, pause awhile, and yield a tribute of respect to 
the patriot whose ashes are here inurned" (3.256). With this sentimental ending, Kendrick sublimates Ianthe's patriotism into a love for her dead brother and new husband and reveals his ultimate intention: to have this newly formed British-Greek couple carry forward the Byzantine tradition (and to bring back to Greece, with British assistance, that empire's glory).

\section{Alexis's Death, Sidney and Ianthe's Marriage, and British Proprietorship over Greece's Past}

In Dream Nation, Gourgouris provides an analysis of philhellenic texts that, I suggest, helps us to understand more fully the ideological work being conducted in The Travellers and to recognize what Kendrick ultimately hopes to achieve with his novel's conclusion. According to Gourgouris:

[T]he text of Philhellenism reveals a double strand: it presupposes in modern Greece both a guardian of the origins of European civilization and a modern State whose development is entirely subjugated to contemporary European interests. In other words, Philhellenism treats the origin of modern Greeks both as symbolic capital and as a contemporary political investment. (143)

Although Gourgouris focuses predominantly on European philhellenism's preoccupation with the Ancient Greek past, I propose that his argument about philhellenic works regarding the Greek past "as symbolic capital” and "as a contemporary political investment" is equally relevant to Kendrick's allusions to the Byzantine (i.e. Roman) past in The Travellers. Specifically, I contend that Sidney's marriage to Ianthe and Alexis's burial in Britain, though sentimentally gratifying plot developments, are problematic events that demonstrate Kendrick's belief that Britain should control the narrative of Modern Hellenism, which included the Byzantine imperial past. With Alexis's death, Sidney's marriage to the last remaining heir of the 
Palaeologus family (whom he pacifies by bringing to England) symbolizes the British man's central position in ensuring a successful Greek national future.

As Alexis was "the last male descendant of the imperial line of the Palaeologi," it is Ianthe and her British husband (and the children that Kendrick informs us that they bear) who are now the descendants of Greece's past and its best hope for a successful future. Although Greece in the 1770s has failed to obtain its liberation, it is from the ashes of this failed revolution that Greece will rise again, a point clarified by a dying Alexis who tells Sidney: "Our unhappy failure will naturally excite the pity of Europe ... But thou must combat the illiberal and unthinking remarks that will flow from the lips of those who treat the restoration of Greece as a vain and chimerical hope" (3.239-40). In lines that are relevant both to past and present historical contexts (the 1820s Greek revolution was in real danger of failing and had many European detractors), Alexis represents his death as an investment in Greece's future, one that he is determined to root (quite literally) in the British soil, as his dying wish to Sidney is that his ashes "might be deposited underneath the remains of his royal ancestor" (3.257) in Landulph. Ultimately, both the dead Modern Greek male and subdued Modern Greek female are the "symbolic capital" through which the Britain of Kendrick's novel can forge its "contemporary political investment" in Greece.

The Travellers' problematic ending extends upon the ideological work Kendrick has been conducting throughout the novel in order to position Britain as the conservator of Greece's past, present, and future. In particular, I argue that Kendrick's philhellenic narrative of the past that advocates for a British-Greek alliance depends upon demonizing and orientalizing Modern Greeks. Although The Travellers focuses largely on Sidney's relations with the virtuous Condili siblings, the novel features many Greek characters with questionable values, including Negri, a 
man of "mixed Frank and Asiatic fashion" (1.135) who is jealous of Sidney and Ianthe's relationship and Georgios, Sidney's lazy servant who gossips about his master behind his back. In a plot development that recalls the 1824-25 Greek civil war between mainland and islander Greeks which revealed major ideological differences concerning an independent Greece, Negri and Georgios collude to extract information from their fellow Greeks, which they in turn deliver to the Ottomans. ${ }^{10}$ With Negri's assistance, the Ottomans penetrate the walls of Mystras, where the Greek troops are stationed, allowing them to score a decisive victory against the Greeks. The Ottomans are victorious, then, because the Greeks are unable to cooperate with one another, making them vulnerable to treachery from their fellow subjects. As Alexis pronounces upon his deathbed: "The fault of one Greek has ruined the happiness of thousands; nay, it has cast a stigma on the race itself" (3.238). Like many writers before him, both philhellenic and mishellenic, Kendrick mercilessly orientalizes the Greeks (here, by calling into question their nationalist values) in order to support his broader vision of British intervention in Greece.

Kendrick's portrayal of Negri and Georgios's behaviour is not an isolated judgment of Greek national character, either, as the author represents many of the Greeks in his novel as possessing vicious natures. For example, after the Greeks execute the Turkish residents of Mystras in one of the novel's more gruesome scenes, Kendrick writes that An odd and grotesque scene presented itself when the army had effectually plundered the bodies of the dead Ottomans. The Greeks, in short, out of a spirit of triumph, arrayed their persons in the finery they stripped off the unfortunate foe. Turbans of every colour and texture were either worn by them instead of their red

\footnotetext{
${ }^{10}$ For a thorough discussion of the Greek civil wars, which take place in the middle of Greece's revolutionary war, see Chapter 23 of William St. Clair's That Greece Might Still be Free: The Philhellenes in the War of Independence, Oxford: Oxford University Press, 1972. Important to note is that Kendrick's representation of Greek defectors in the 1770s war who betray their fellow countrymen is purely fictional literary (and ideological) flourish.
} 
caps, or else perched on the tops of their fusils. Others of the Greeks arrayed themselves in the jackets, yellow boots, and trowsers obtained in the same way. $(3.80-81)$

Here, the Greeks visually orientalize themselves for a British audience that watches as they adopt the dress of their rivals. Not only is the Greeks' conduct in poor taste, it also betrays how similar they are to the Ottomans whom they decry as their oppressors, confirming some Europeans' fears that the Greeks were akin to their Eastern rulers. In a matter of moments, the subjugated act the part of the victimizers. To punctuate this point, Kendrick writes that, shortly following this episode, some of the soldiers begin to enter the private homes of their fellow Greeks, "assuming the same liberties with the women as they did with the provisions" (3.106). It is portrayals such as these, I argue, which demonstrate that Kendrick's endorsement of stronger British-Greek relations throughout The Travellers runs parallel with a troubling depiction of the Modern Greeks which encourages British command over Greek affairs and represents the British as better guardians of Greece's ancient legacy than the Greeks themselves.

\section{"Raymond Was Loved By Evadne": A Greek Tragedy}

In The Last Man, Mary Shelley provides Greece with the kind of British saviour Kendrick would approve of: Lord Raymond, a man beloved by the Greeks who consider him their "darling hero" and for whom they compose national airs celebrating "his glory, valour, and munificence" (31) after he has commanded them to victory over the Ottomans. However, though Shelley emphasizes the importance of Raymond's mission, The Last Man is not preoccupied with celebrating his or Britain's role in liberating the Greeks, but instead in anticipating the potential directions and consequences of British-Greek political relations following Greece's national 
independence. To perform this analysis, Shelley projects her narrative (very distantly) into the future, to the year 2092.

As Shelley's framing narrator clarifies in the Introduction to The Last Man, the novel itself is a dictation of a prophecy she has found on scattered leaves and bark during a visit to the Sibyl's Cave in Naples (Mary and Percy visited these caves together in 1818). ${ }^{11}$ On these fragments of leaves and bark, the narrator discovers a history written by Lionel Verney, who in 2100 will become the world's "last man." 12 Importantly, the narrator notes that, because Lionel's tale is printed on random leaves and bark, and composed in various languages, she has had to be selective in her reconstruction of parts of the prophecy in order to create a narrative out of the "sacred remains" (4) she has collected: "[s]cattered and unconnected as they were, I have been obliged to add links, and model the work into a consistent form" (4). The way that readers encounter Lionel's prophetic history depends largely upon the narrator's editorial choices.

Shelley's decision to begin The Last Man with this Introduction was unpopular amongst critics of the novel, with the Literary Gazette and Journal of Belle Lettres calling it "not very skillfully imagined" (102). Of all reviewers, the critic for the Panoramic Miscellany most pointedly objected to Shelley's narrator, who positions herself as the decipherer of the prophecy: Here then the machine, so elaborately constructed, is, at once, destroyed. The sibylline leaves are blown away at a breath. It is no longer a transcript of future,

\footnotetext{
${ }^{11}$ In Vergil's Aeneid, the Sibyl (or Sibylla) prophesizes Rome's future greatness to Aeneas while he is travelling to Latium from Tunisia along the Italian coast. More, Aeneas learns from the Sibyl about his future offspring's greatness, which gives him the strength to continue with his journey. The Sibyl's prophecy and the Sybilline Books (a collection of oracular prophecies) were enormously important in cultivating the cult of Rome and its greatness from the early Republic onwards. See Book VI of the Aeneid.

${ }^{12}$ The leaves therefore simultaneously represent a prophecy from the past (the Sibyl's) and the future (Lionel's). As Gregory O'Dea clarifies, "Verney's narrative is thus a written history and record of one human being's past, but it is also a superhuman prophecy told by the Sibyl, and a record of humankind's future. Considered in this way, The Last Man becomes a prophetic history in which the future and the past have collapsed into one another, ultimately to become the same thing" (291). See Gregory O'Dea, "Prophetic History and Textuality in Mary Shelley's The Last Man," Papers on Language and Literature 28.3 (1992): 283-304.
} 
or revealed history, but an avowed fable or invention of the writer, who, discarding the assumed and lofty pretension of transcribing the oracles of truth and inspiration, acknowledges herself explicitly to be "cloathing her own fiction in ideality." (380)

For the reviewer, Shelley transgresses the rules of good literary fiction by presenting the narrative as neither solely the Sibyl's prophecy nor Lionel's own tale, but as one that is ultimately dictated and constructed by a narrator who is not implicated in the main story. According to the Panoramic Miscellany critic, "[t]wo ways of directing this machine would obviously present themselves. The sibyl might either be feigned to have written in her own person, prophetically, the history that was to follow, or prophetically to have pretranscribed the history that some future historian was to write" (381). Despite the Panoramic Miscellany's objections to Shelley's narrative choices, however, I argue that her decision to feature a narrator who confesses that the story depends at least partially upon her interpretation and imagination represents the novelist's determination to use literary history neither to recount verifiable events or pure facts, nor to have her readers totally suspend disbelief, but to instead examine the ways in which past and present political actions and decisions potentially impact the future. Shelley wanted The Last Man to reveal explicitly the connectedness and tensions between historical truth and literary fiction. "By representing The Last Man as an historical artifact," argues Gregory O’Dea, "Shelley explores not only the story itself, but the ways in which stories are (or could be) gathered, collated, shaped and maintained - that is, ways in which history is textualized" (302). Indeed, as O’Dea writes elsewhere, “[a]s a work of futuristic fiction, The Last Man offers a speculative solution to the historian's theoretical problem: through a complex inter-relationship of artifact, manuscript, and narrative-historical perspective, the novel is able to give historian and 
reader alike the double effect of distinction and immediacy in both public and private history" (290). The Last Man presents a narrative that plays with notions of past, present, and future, of historical distance, and of literary fiction, so that readers feel simultaneously bound to and estranged by the history it tells - it is both mere storytelling and an all too possible reality. "The text," writes O'Dea, "forms a tapestry of past, present, and future in that it relates the future of various pasts, various pasts of the present, and so on: the prophetic history becomes a Gordian knot of time as 'a moving image of eternity,' in which human distinctions between past, present, and future have little purpose" (293). O'Dea's argument is confirmed by many plot points in The Last Man, including Shelley's depiction of Greek independence achieved in the year 2092: it is never clarified whether this is Modern Greece's first instance of freedom from Ottoman rule after what would surely be the world's longest war, or a separate war from that of the $1820 \mathrm{~s}$. By presenting a speculative (and thus obviously fictional) account of the future that disorders and conflates notions of past, present, and future, Shelley can demonstrate for her readers how the three time periods intersect and how a better understanding of one's own historical past and present can help to shape a better future, what Anne McWhir deems a "dismantl[ing] [of] chronology and identity to reconstruct history as a kind of visionary synchronicity" (xxvii).

While such scholars as Anne K. Mellor and Morton D. Paley have emphasized the pessimism of Shelley's vision of the future, I agree with critics like Fuson Wang who argue that "Shelley continuously rewrites redemptive narratives into The Last Man and gives shape to a politics of possibility that recovers the novel from charges of nihilism or anti-Romantic conservatism" (236).$^{13}$ Indeed, I argue that Shelley's addition of a framing narrator in her

\footnotetext{
${ }^{13}$ In Mary Shelley: Her Life, Her Fiction, Her Monsters, Anne K. Mellor claims that Shelley "projected into her novel all the guilt and resentment she felt towards her husband and the political ideology he espoused" and that "The Last Man first undercuts the dominant systems of government of the early nineteenth century and then shows that all cultural ideologies are but meaningless fictions" (144); Morton D. Paley in "The Last Man: Apocalypse Without
} 
Introduction signals the novelist's intention to use her novel to promote a less antagonistic and violent future for Britain, Europe, and the East. Without the framing narrator in the Introduction, the story might be read as being completely nihilistic, but with her intervention into Lionel's history, The Last Man provides a "roadmap for political change" (Fisch 273). The framing narrator is, as she admits, merely attempting to decipher the Sybil's prophecy which is, like the prophecies of all oracles, open to interpretation. Shelley's introduction of the framing narrator who is an interpreter allows the story Lionel tells to be regarded by her readers as either an utterly nihilistic tale or, alternatively, one that inspires social, political, and cultural change. Ultimately, readers themselves become interpreters of Shelley's novel and decide upon The Last Man's intended meaning and moral. And if Shelley's literary precedent-Vergil's Aeneas, wherein the Sibyl prophesizes Rome's future greatness to Aeneas during an arduous period in his life — is any indication, there is perhaps reason for hope in moments of despair.

Shelley's experimentation with historical storytelling (and specifically, her narrative of a Constantinopolitan Plague that kills off the human race) allows her to use a past imperial dynasty and a present revolutionary war to warn her readers about the perils of Britain's (current and anticipated future) aggressive imperialist policies and the dangers inherent in her country's promotion of fervent nationalism in foreign countries. By representing a post-apocalyptic world triggered by Britain's assistance to a Greek nation that desires territorial expansion, Shelley proposes an alternative to the imperial-national transcultural relations between Greece and Britain that she feared would develop following Greece's liberation. ${ }^{14}$ In The Last Man, the two

Millennium," argues that "[u]ltimately The Last Man is a repudiation of what might simplistically be termed the Romantic ethos as represented, for example, in the poetics and politics of Percy Bysshe Shelley" (111). See Anne K. Mellor, Mary Shelley: Her Life, Her Fiction, Her Monsters, New York: Routledge, 1989; and Morton D. Paley, "The Last Man: Apocalypse Without Millennium," The Other Mary Shelley: Beyond Frankenstein, Ed. Audrey A. Fisch, Anne K. Mellor, and Esther H. Schor, New York: Oxford University Press, 1993.

${ }^{14}$ Shelley's concerns were tied more generally to the "Eastern Question," a concept that I discuss in Footnote 14 of my Introduction (pp.9-10). 
characters who serve as a warning to readers about a potentially destructive Greek-British foreign alliance are Princess Evadne and Lord Raymond, both of whom die as a result of their political ambitions. Indeed, by portraying an extramarital affair between the Greek Evadne and British Raymond, and suggesting that this relationship puts into motion the processes which initiate the Plague in Constantinople that eradicates the world's population, Shelley personalizes (and makes affective) her critique of Britain's potential role in Greek affairs and advocacy for a less intrusive foreign policy. In fact, Shelley suggests that the Plague could have been avoided if Evadne had chosen to align herself politically and romantically with the republican Adrian, the last King of Britain's son (the Britain of 2092 is a republican state) instead of with Raymond, who wants to reinstitute the monarchy. ${ }^{15}$

When readers are first introduced to Evadne, she is an 18 year old princess living in Britain with her father Prince Zaimi, ambassador to England from the free States of Greece, following England's transition from monarchy to republic. Although Adrian is infatuated with the young woman, she does not reciprocate his feelings, but instead falls in love with Raymond. Evadne's lack of interest in Adrian and attraction to Raymond, Shelley suggests, relates to the Greek woman's personal passion for and investment in the British lord's (self-serving, imperialist) politics, which correspond with her own. While Adrian's political goals—such as witnessing the "improvement of mankind," "reform of the English government," and "greater

\footnotetext{
15 cf. Procopius's account of the Constantinopolitan plague (known as the Plague of Justinian) that first broke out in 541 B.C. in the Byzantine Empire's outer borders. The plague killed about 25 to 50 million people (between 10-20\% of the world's population) and returned periodically for 250 years. Procopius blamed the plague on Justinian's rule and based his account on Thucydides's account of plague in Athens. See Book 2, xxii-xxiii of Procopius, History of the Wars, Volume 1, Trans. H. B. Dewing, Cambridge, MA: Harvard University Press, 2016; Averil Cameron, Procopius and the Sixth Century, London: Routledge, 1985; and Anthony Kaldellis, Procopius of Caesarea: Tyranny, History, and Philosophy at the End of Antiquity, Philadelphia: University of Pennsylvania Press, 2004. In Mary Shelley (London: John Murray, 2000), Miranda Seymour suggests that Shelley decided to write a novel about a plague that wipes out the world when she returned from Italy to London following her husband's death; one of the inspirations for the novel, according to Seymour, was the work of artist John Martin, especially his paintings The Destruction of Herculaneum (1822) and The Seventh Plague (1823). See pp.330-31.
} 
equalization of wealth and privilege" (34) — are admirable, they are not endearing to Evadne because she believes them overly abstract and a sign of the monarchy's waning power (and thus of her own privileged position). As Shelley writes, "Evadne entered but coldly into his systems. She thought he did well to assert his own will, but she wished that will to have been more intelligible to the multitude. She had none of the spirit of the martyr, and did not incline to share the shame and defeat of a fallen patriot" (34). On the other hand, Evadne is infatuated with Raymond because he is "emphatically a man of the world" who "looked on the structure of society as but a part of the machinery which supported the web on which his life was traced" (35). Raymond's egotistical political outlook, which allows him to believe that "[t]he earth was spread out as an highway for him; the heavens built up as a canopy for him" (35), attracts an equally self-centred Evadne: "Raymond, the deliverer of Greece, the graceful soldier, who bore in his mien a tinge of all that, peculiar to her native clime, Evadne cherished as most dearRaymond was loved by Evadne" (35).

Monarchist Raymond and republican Adrian represent two different versions of England (both of which Shelley can depict by setting her story in 2092) and for Evadne—-both literally and figuratively a representative of a liberated Greece, albeit a troubling one - to choose Raymond over Adrian signals her preference for an imperialist Britain. Indeed, as an overly confident and ambitious Raymond tells Lionel of his future political aspirations: "[M]y first act when I become King of England, will be to unite with the Greeks, take Constantinople, and subdue all Asia. I intend to be a warrior, a conqueror; Napoleon's name shall vail to mine; and enthusiasts, instead of visiting his rocky grave, and exalting the merits of the fallen, shall adore my majesty, and magnify my illustrious achievements" (45). Evadne desires men like Raymond 
(who imagines himself to be a modern day Alexander the Great) because they can help her to realize and to advance her own imperialist ambitions.

Evadne's political scheming becomes evident when she returns to England after a sevenyear absence in Greece, following Raymond's marriage to Lionel's sister Perdita and her rejection of Adrian. Upon her arrival in England, the now destitute Greek woman reconnects with Raymond,- who has become Protector of England - to whom she anonymously sends sketches for a national gallery which he plans to erect. After Raymond discovers that Evadne is the artist, the two begin an affair. In time, Evadne explains to her lover why she was forced to depart from Greece:

She married; and carrying her restless energy of character with her into new scenes, she turned her thoughts to ambition, and aimed at the title and power of Princess of Wallachia; while her patriotic feelings were soothed by the idea of the good she might do her country, when her husband should be chief of this principality. She lived to find ambition, as unreal a delusion as love. Her intrigues with Russia for the furtherance of her object, excited the jealousy of the Porte, and the animosity of the Greek government. She was considered a traitor by both, the ruin of her husband followed; they avoided death by a timely flight, and she fell from the height of her desires to penury in England. (88)

Evadne's political overreaching — her "restless energy of character" and twice-mentioned "ambition"— causes her own demise and foreshadows the damaging effect Evadne and Raymond's affair will have upon The Last Man's other characters. Even if the Greek woman attempts to justify her aspirations for becoming Princess of Wallachia (an Ottoman territory governed by the Greeks) by appealing to "patriotic feelings," Lionel's narration makes clear that 
Evadne's political angling is self-serving and to blame for alienating both Ottoman and Greek governments, as well as for causing her husband's indigence and death.

Selfishly entering a series of relationships to help her fulfill her political goals, and even going so far as to have an affair with a married man (Raymond), Evadne is a largely unsympathetic character who certainly does not conform to the idealized (feminized, tameable) vision of Greece imagined by so many Europeans, a characterization I have discussed in previous chapters of this dissertation, mostly notably in Chapter Three. Instead, her presence in The Last Man problematizes Britain's relationship with Greece and reveals Shelley's own ambivalence about a liberated Greece integrated into a Western sphere of influence. If the Greece of The Last Man is both an ancient country of "grand historical association" (138) and a modern nation of "noisy joy," "gaudy colours," and "the tumult of carriages and horses" (133), "a Greece situated in the interstices of East and West, the Orient and Hellas, and ideologically constructed by colonialist Europe" (Koundoura 165), it is Evadne who inhabits these contradictory significations and reveals how volatile "Greece" is if its sociopolitical identity is not properly understood or managed.

Although Evadne's "fluid transversals of national, cultural, and gendered borders make her one of the only 'free' people in the novel" and "allow her to circulate freely among the masculine architectural and military circles of England, Greece, and Turkey" (Wang 248), she is ultimately always an outsider in the novel. Introduced early in the novel's English scenes, Evadne is never completely invited into the idealized circle shared by her British acquaintances at Windsor Castle, a group which includes Lionel, Perdita, Raymond, Adrian, and Adrian's sister Idris. More, when Evadne returns to the still largely Ottoman-controlled Levant, she does not fit in there, either. In a sense, Evadne models Greece's own ambiguous position as neither entirely 
Western nor Eastern, a position that Shelley portrays as volatile and potentially destructive. Raymond, though, believing himself powerful enough to appease and tame Evadne,- - his ultimate goal is to "restor[e] her to society; and the enjoyment of her rank" (98) before separating from her indefinitely — is blind to the potential dangers of the Greek woman's alterity. As Lionel states, "while Raymond had been wrapt in visions of power and fame, while he looked forward to entire dominion over the elements and the mind of man, the territory of his own heart escaped his notice" (90).

Whereas Sidney and Ianthe's relationship in The Travellers symbolizes hope for Greece's future, Raymond and Evadne's represents chaos. Eventually abandoned by the man she loves, Evadne becomes a darkened version of the Hellenic, her personal vendetta against Raymond becoming a worldwide curse. However, although Evadne is undoubtedly to blame for wishing the Plague upon Raymond, Shelley suggests that the British lord is perhaps even more culpable than the Greek woman for causing its spread. Indeed, after Raymond's affair with Evadne is revealed and the lord's private and political life in Britain are ruined, he resolves to rejoin the Greeks in their endeavour to regain Constantinople. Raymond's relationship with Evadne culminates in his final journey to Greece, a country that continues to present an ideal stage for his personal vanity and political ambitions. However, whereas Kendrick in The Travellers supports a Greek-British relations built upon an alignment between British and Byzantine Greek empires, Shelley instead represents Constantinople, the Byzantine capital, as a centre of ethnic, religious, and national discord. By depicting Evadne and Raymond's cross-cultural relationship, built upon a mutual proclivity for selfish political ambitions and imperialist designs, as the impetus for Raymond's decision to return to Greece and to help the Greeks raid Constantinople, 
Shelley transforms the illicit affair into a broader warning about the wrong kind of intercultural relationship.

\section{"On the Height of St. Sophia": Constantinople and the Perils of East-West Conflict}

Shelley's decision to feature Constantinople as the site where Raymond and Evadne's

relationship encounters its ultimate breakdown, culminating with the Greek woman cursing

Raymond with a Plague that kills him before spreading throughout the world, is less an

indictment of the East, I suggest, than an attempt to make the former Byzantine capital a

metaphor for a breakdown in East-West relations. ${ }^{16}$ In fact, Constantinople presented itself as an

ideal example through which Shelley could historicize the dangers of imperial aggression and

collusion, as the Byzantine capital was (and still is) a topos that for Greeks simultaneously

evoked past, present, and future imperial memories and ambitions. Although during the Greek

War of Independence most European philhellenes conceptualized the war as a rebirth of the

Ancient Greek past, the majority of Greeks were of a different mind. Instead of merely a revival

of ancient political doctrine, Greeks believed liberation from the Ottoman Empire would create

the opportunity for them to reclaim "all the lands of Classical and Byzantine Hellenism"

(Herzfeld 119), giving Greece "the widest territorial expanse that Greek culture had ever

experienced" (Herzfeld 128). Especially important to the Greeks was the reconstitution of Hagia

Sophia, the Orthodox Greek seat of the Patriarch of Constantinople, which was conquered by

Mehmed II in 1453 and converted into a mosque (Ayasofya, as it is now named, is today a

\footnotetext{
${ }^{16}$ In making this argument, I am extending upon Anne Mcwhir's assessment that "[i]t is tempting to situate the source of that evil in the foreign and the alien, recognizing Mary Shelley participates in the demonization of Islam by Christian Europeans that goes back to the crusades" (xxviii); and James P. Carney argument that "[a]s an eventuality of eastern origin - it first emerged 'on the shores of the Nile [and in] parts of Asia' (Shelley 127) - the plague is identifiable with what Anne K. Mellor calls the 'Judaeo-Christian demonic other' (xxiii)" (528). Although these arguments are credible, my focus is less so on the supposed origin of the Plague, and more so on the reasons Shelley provides for its spread. See Anne McWhir, "Introduction," The Last Man, Ed. Anne McWhir, Peterborough, ON: Broadview, 1996, pp. xii-xxxvi; and James P. Carney, "Some Previously Unrecognized References to Classical Historians in Mary Wollstonecraft Shelley's The Last Man," Notes and Queries 61.4 (2014): 527-30.
} 
UNESCO World Heritage Site). The Greeks' ambitious political goal to reclaim their past territorial lands, an idea which was only formally introduced in 1844 as Megali Idea (Great Idea) by Prime Minister Ioannis Kolettis, nonetheless captured the imagination of many Greeks during the Greek War of Independence. By depicting Raymond leading the Greeks to battle for Constantinople, Shelley represents a contemporary desired reality for many Greeks who imagined a future territorially-expanded Greece even before liberation had been achieved.

The Hellenic expansionist dream, however, quickly becomes a nightmare in The Last Man in a narrative sequence that exposes the destructiveness of past (1453), present (1820s), and future (2092) political and ethnic conflicts. As Raymond and his army of Greeks prepare to raid Constantinople, Shelley for the first time in the novel references the Plague, a disease which she implicitly equates with Greek-Ottoman conflict, when she writes that "neither plague nor war could prevent Perdita from following her lord, or induce her to utter one objection to the plans which he proposed" (137). Although Raymond is warned of the potential dangers of invading a plague-ridden Constantinople, he is nonetheless determined "to repay the kindness of the Athenians, to keep alive the splendid associations connected with his name, and to eradicate from Europe a power which, while every other nation advanced in civilization, stood still, a monument of antique barbarism" (137). Raymond's raid of Constantinople represents the establishment of a new Greece (modelled on Greece's past territories), a country that will join Europe once it separates itself geographically and ideologically from the Ottoman east. "True to the ideal of revolution," writes Van Steen, "modern Greece would take the right historical turn, leaving the rest of the Orient to be just that: the nonrevolving, unresolved, unchanging, and unenlightened Orient" (172). Indeed, by deeming the Ottoman Empire "a monument of antique barbarism," Raymond deprecates the Muslim world and justifies the mission of philhellenes like 
himself who wanted "to reconstitute a Greek cultural space that was separate from the Ottoman territories-and occupiers" (Van Steen 165).

A geographically-expanded Greece, however, is an ambition that ultimately goes unfulfilled in The Last Man and, ironically, it is Raymond's scorned Greek lover Evadne who prevents the fulfillment of the British lord's dream to make Constantinople Greece's once more when she puts a curse on her former partner. Hearing "a piercing shriek" (142) from the battlefield, Lionel discovers a wounded and dying Evadne who has dressed like a soldier in a final effort to reunite with Raymond. As she dies, Evadne proclaims,

"This is the end of love! ... Many living deaths have I borne for thee, $\mathrm{O}$ Raymond, and now I expire, thy victim! — By my death I purchase thee-lo! the instruments of war, fire, the plague are my servitors. I dared, I conquered them all, till now! I have sold myself to death, with the sole condition that thou shouldst follow me-Fire, and war, and plague, unite for thy destruction- $\mathrm{O}$ my Raymond, there is no safety for thee!" (142)

Unlike The Travellers' Ianthe, who is subsumed into British society, Evadne proves subversive to the last. Evadne's foreignness and volatility, argues Maria Koundoura, represent a challenge to the idealized domestic circle at Windsor Castle and ultimately prevent her from "pass[ing] as the sublimated English subject ... with whom readers can identify" (91). This is true; however, while Koundoura claims that Evadne's nonconformity is a sign of the novelist's complicity with Orientalist representations of Greece-that Shelley "uses the discourse of ethnocentrism to incorporate that outsider into a masculinist and Eurocentric narrative of origins" (91) —I suggest that Shelley's portrayal of the Greek woman is more sympathetic and nuanced than Koundoura allows. By indicating that Evadne curses Raymond (causing the Plague to spread) in a final, 
desperate act of dissent against the British man's treatment of Greeks like her for his own personal gain, Shelley demonstrates that her problematic characterization of Evadne represents a warning to readers about the dangers of Britain's cultural authoritarianism, rather than her personal unease with Greeks. Evadne, the novel's ultimate other-foreigner, woman, neither entirely Eastern nor Western — sacrifices her life in order to curse Raymond and, as a result, destroy Greece's hopes for a reconstituted Constantinopolitan capital, as a way to protest the British man's exploitation of her and her country.

Although The Last Man's Plague is an admittedly extreme plot element, I suggest that Shelley introduces it into her novel to expose as "diseased" the Orientalist politics practiced by Westerners like Raymond, an outlook on the "East" wherein Greece becomes a platform for vainglory and Greeks like Evadne are disposable. Although Raymond attempts to negotiate and control the narrative of Greece—-both on a personal level when he promotes Evadne's assimilation into British society, and on a public level when he leads the charge to capture Constantinople - he ultimately fails to recognize the dangers of his domineering conduct because of his cultural vanity and sense of moral superiority. Indeed, even when his army of Greeks warns him that the Ottomans are not resisting the Greeks' penetration of Constantinople's gates (a sign that they have been consumed by the Plague), Raymond is still foolhardily determined to “"plant the Grecian standard on the height of St. Sophia"” (153), converting it from mosque to church. Raymond's religiously- and imperially-motivated mission ends up bringing to fruition Evadne's curse: as Raymond and Lionel enter Constantinople, an apocalyptic scene is set into motion, with explosions and flames consuming St. Sophia and the plague infecting and killing Raymond before spreading to the rest of the world. 


\section{"I Will Leave a Monument of the Existence of Verney": The Plague in Britain and the Advent of a New History}

Following Raymond's raid of Constantinople, Shelley focuses predominantly on how the Plague affects Britain. Shelley features numerous scenes with British characters encountering the reality of the Plague and its approach toward their country in order to emphasize that Britons are connected to an Orientalist politics that devastates the East, whether they understand themselves as being complicit or not. Although Britons initially believe they cannot be infected by the Plague - Lionel tells readers "[1]et us weep for our brethren, though we can never experience their reverse" (184) - they soon realize that their country's fate is linked to events in the East. ${ }^{17}$ In particular, the Plague weakens the quality that Shelley believes makes Britain so prosperous: its engagement with the rest of Europe and the Mediterranean. Britain, Shelley suggests, depends upon open borders for its political, cultural, and commercial prosperity; the Plague, however, forces the country to become more insular and inward-looking. As Lionel explains, "[n]ations, bordering on the already infected countries, began to enter upon serious plans for the better keeping out of the enemy. We, a commercial people, were obliged to bring such schemes under consideration; and the question of contagion became matter of earnest disquisition" (182). As a result of the Plague, "[t]he English, whether travellers or residents, came pouring in one great revulsive stream, back on their own country" (186) in a move that emphasizes the dangers of Britain's partaking in ethnic and religious conflicts in the Eastern world.

\footnotetext{
${ }^{17}$ Other examples of British exceptionalism include when Lord Protector Ryland tells Lionel “"it is as wise to discuss the probability of a visitation of the plague in our well-governed metropolis, as to calculate the centuries which must escape before we can grow pine-apples here in the open air"' (173); and when Lionel himself states "[i]n the sunny clime of Persia, in the crowded cities of China, amidst the aromatic groves of Cashmere, and along the southern shores of the Mediterranean, such scenes had place. Even in Greece the tales of the sun of darkness encreased the fears and despair of the dying multitude. We, in our cloudy isle, were far removed from danger, and the only circumstance that brought these disasters at all home to us, was the daily arrival of vessels from the east, crowded with emigrants, mostly English" (177).
} 
By focusing on the how the Plague, in a sort of reverse colonialism, dissolves Britain's prominent position in Europe, to the point that "[t]he overgrown metropolis, the great heart of mighty Britain, was pulseless" and "[c]ommerce had ceased" (204), Shelley exposes the precarious line between cosmopolitanism and imperialism. Britons may have integrated themselves into European society—and indeed, as the Plague ravages Europe, Lionel and his family offer refuge to "foreign friends whom we eagerly sought out, and relieved from dreadful penury" (186) — but an aggressive, antagonistic politics like Raymond's ultimately jeopardizes Britain's position in the world. Raymond's imperialist mission, reflective of early nineteenthcentury Britain's foreign policy in many parts of the world, creates an undiscriminating Plague that ultimately kills off all humanity.

Although Raymond's Orientalist politics fail Greece, Britain, and the world, Shelley earlier in her novel indicates there is an alternative to Raymond's outlook on the East by having Adrian speak about his own experiences in Greece. Returning to Windsor after having fought on behalf of the Greeks, Adrian tells his friends that, even though "I shall not be suspected of being averse to the Greek cause; I know and feel its necessity; it is beyond every other a good cause" (123), he nevertheless rejects a view of the Turks that deprives them of their humanity. As he states,

But let us not deceive ourselves. The Turks are men; each fibre, each limb is as feeling as our own, and every spasm, be it mental or bodily, is as truly felt in a Turk's heart or brain, as in a Greek's ... They were men and women, the sufferers, before they were Mahometans, and when they rise turbanless from the grave, in what except their good or evil actions will they be the better or worse than we? (123-24) 
Here, Shelley urges her readers to reject East-West distinctions and to consider the similarities between Britons, Greeks, and Turks, rather than focusing only on the fact that Turks are Muslims (Mahometans). Religious (and ethnic) distinctions, suggests Adrian, are less important than mental and physical affinities and moral behaviours. Adrian's nuanced and compassionate perspective on the Turks, he understands, is discordant with the dictates of war, however. Although Adrian laments that his experiences in Greece have taught him "that one man, more or less, is of small import, while human bodies remain to fill up the thinned ranks of soldiery," he recognizes that successful leaders like Raymond view war differently: "All this has a different effect upon Raymond. He is able to contemplate the ideal of war, while I am sensible only to its realities" (124). Adrian's account of Greco-Ottoman warfare, though having no effect on the novel's narrative trajectory, serves to highlight Shelley's rejection of Raymond's Orientalist politics that justify his imperialist agenda and to foreshadow the devastating consequences of East-West conflict that the novelist goes on to detail.

Shelley's inclusion in her novel of Adrian's war experience in Greece, too, might help readers to glean from The Last Man a more positive outlook on East-West affairs. At the beginning of my analysis of The Last Man, I argued that, despite her portrayal of a Plague that ravages the world, Shelley's vision for Britain's future is not entirely hopeless. Indeed, Shelley's addition of a narrator who collates and interprets Lionel's prophecy indicates the importance she attributes to historical meditation and emphasizes that the novel is, ultimately, fiction-even if it is an all too possible fiction to be avoided. The closing chapters of The Last Man, I propose, demonstrate Shelley's commitment throughout her novel to a more reflective outlook on, and participatory role in, the social and political forces that drive history forward. Forced to flee England, Lionel finds himself alone in Italy after his final two companions (Adrian and Clara, 
his niece) drown attempting to reach Athens. There, Lionel refuses to "live among the wild scenes of nature" and instead chooses to inhabit Rome, "the capital of the world, the crown of man's achievements" (358). Lionel visits many of the ancient (and now ruinous) sites, including the Roman Forum and Coliseum, which have inspired and captivated individuals for millennia. On the one hand, these sites remind readers about the ravages of time and history, what Carney deems "a key rhetorical strategy" by Shelley "that aligns European modernity with the collapse of utopian projects in the classical past" (530). However, on the other hand, these historical spaces, which were the sites of public discourse, commercial activity, and community life, also remind Lionel (and readers) what it means to be a member of a millennia-long Western history. In Rome — quite literally, by walking through history—Lionel becomes an active participant in the past, and of the present and future.

In Society and Sentiment, Mark Phillips argues that "historical pilgrimage is rooted in some of the oldest habits of Western culture, but it also points to a perception of history that has been increasingly cultivated since [the late eighteenth century]" (322). From the late eighteenth century onwards in Britain, history has become "not only a story to be narrated" but "also an experience to be evoked ... History, traditionally regarded as a book to be read, has become a scene to be revisited" (Phillips 322). As Phillips notes, it was writers like Shelley's father William Godwin who were instrumental in popularizing for Britons "a new relationship to history that is essentially spectatorial and inward" (324) in such works as his Essay on Sepulchres, an essay that served as "a proposal for erecting some memorial of the illustrious dead in all ages on the spot where their remain has been interred" (324). However, while Godwin's Sepulchres focuses on monumentalizing British "reformers, instructors and improvers" (6), Shelley in The Last Man highlights less the achievements of individuals and 
instead focuses on sites where collective societal efforts created flourishing cultures. In other words, whereas Godwin in Sepulchres encourages a form of historical meditation that is nationally commemorative, Shelley in The Last Man asks her readers to celebrate the histories of various civilizations.

Shelley's commemoration of the world's great cultures begins in Rome, where Lionel rediscovers his love for literature, is inspired to write his own history, and finally, is compelled to travel eastwards to discover other cultures. Importantly, Lionel's tour through Rome's historical sites help him to remember Romantic-era literary works about the city, including Ann Radcliffe's The Italian (1797) and Germaine de Staël's Corrine, ou l'Italie (1807), inspiring him to visit the libraries of Rome and exercise his imagination. As Betty T. Bennett argues, "[i]n Verney's decision to go to Rome ... Mary Shelley offers not only another meaning to the notion of extinction, but to what she regards as the life-force of existence itself: the imagination" (151). Through devastation, Lionel rediscovers his own humanity and connectedness to human culture, first endeavouring to read various literary and historical works in such public forums as "the fair temple in the Borghese Gardens, or under the old pyramid of Cestius" (363), before ultimately deciding to compose his personal history for posterity. ${ }^{18}$ As Lionel writes, "I will leave a monument of the existence of Verney, the Last Man. At first I thought only to speak of plague, of death, and last, of desertion; but I lingered fondly on my early years, and recorded with sacred zeal the virtues of my companions" (364). Significantly, Lionel's narrative, which includes the personal stories of those people closest to him, stands in contrast to Raymond's conception of history, which O'Dea deems a "self-conscious creation of events and a persona that will be, in history's records, offered as a narrative picture of the past" (295). Instead, Lionel's narrative

\footnotetext{
18 "The old pyramid of Cestius" is located at the Protestant Cemetery (Cimitero Acattolico) in Rome, the site of P.B.
} Shelley's burial. 
rejects grand historical narratives (recall, Raymond aspired to be a modern day Alexander) for a more personal engagement with history that underscores Shelley's endorsement of an affective relationship with time. Finally, by having Lionel travel from Italy to Scylla and Charybdis, Malta, the Cyclades, Asia Minor, Syria, Carthage, and Libya to learn about the cultures and literatures of various regions, Shelley provides readers with a roadmap for further historical meditation and, with it, cross-cultural understanding. "The libraries of the world are thrown open to me- and in any port I can renew my stock" (367) announces Lionel on the final page of The Last Man before he begins his journey, a statement that emphasizes Shelley's alignment of Lionel's physical journey with historical knowledge-making. Engaging affectively with history and literature, The Last Man suggests, can help people to better understand the cultural, social, and political processes that shape human lives, personal stories like Lionel's (that is, Shelley's novel itself) encouraging a more participatory role in past, present, and future histories.

\section{Greece, Britain, and the Problematic of European Modernity}

On 2 April 1821, Mary and Percy Shelley composed a joint letter to Mary's step-sister Claire Clairmont following their friend and Greek statesman Alexandros Mavrokordatos's revelation to them that the Greeks had publicly announced their intention to revolt against the Ottoman Empire. In the letter, Mary joyously exclaims, "Greece has declared its freedom!" (250) and continues by imagining "[w] hat a delight it will be to visit Greece free" (251). When the Greek War of Independence began, Shelley was enthusiastic about Greece's bid for national sovereignty, approving of the efforts of her friends like Mavrokordatos. Five years after the war commences, however, Shelley seemingly belies her support for the Greeks by composing a novel that punctuates the dangers of British intervention in Greek affairs. As I have argued in this chapter, though, The Last Man does not so much disavow Greece's bid for independence as it 
critiques a Western political alliance that demonized the "Eastern" world with potentially dangerous consequences.

In 1826, when Shelley published her novel, the political climate of Britain and Europe had becoming increasingly conservative and reactionary, and thus less accepting of the liberal and cosmopolitan values espoused by Shelley and her (now dissolved) social circle. As a January 1824 article in The Edinburgh Review on British foreign policy lamented,

Arbitrary government is now maintained all over the Continent of Europe, more openly in theory, and more rigorously in practice, than it was before the French Revolution was heard of; - and political freedom is more jealously proscribed, and liberal opinions more vindictively repressed, than in any period of modern history. 'The wheel has come full circle:' — and after the speculations and experience of thirty-five years, we seem at least as far from political improvement as we were at the beginning! (284)

The writer then asks "[i] s political truth a chimera, and political science a dream? Are the civilized nations of Europe in reality unteachable? —or has the progress by which they have advanced beyond the condition of barbarians, already attained its limits?" (284). Writing The Last Man during what she considered a particularly troubling era in British and European history, Shelley herself must have pondered the limits of European cultural advancement and diplomacy when composing her narrative that addressed the political shortcomings of her period. Shelley feared that Britain's increasingly interventionist role on the European stage would have devastating consequences for other countries, including Britain itself. If Greece were to become truly liberated - a prospect that excited her in 1821 —its national sovereignty, Shelley suggests, should not be dependent upon a politics that deprecates the Eastern world. 
In contrast to Shelley's The Last Man, Kendrick's The Travellers offers what is a predominantly philhellenic narrative, although, as I have argued, the novel betrays a British bias in its portrayal of corrupted and orientalized Greeks who fail to live up to Western standards of etiquette. Indeed, before writing The Travellers, Kendrick had gained a reputation as a British imperial apologist when he published in 1822 his The Ionian Islands. In the history, Kendrick espouses Lord High Commissioner Thomas Maitland's iron-fisted rule over the Ionian Islands as, in his estimation, "[t]he nobility and gentry of the Ionian Islands require a firm-minded governor to keep them from manifesting those dangerous principles so destructive to small states in general; and to the excellent administration of Sir Thomas Maitland, the Islands are indebted for the preservation of civil order" (viii). Importantly, Kendrick celebrates in The Ionian Islands Maitland's prevention of Ionian Island Greeks from aiding mainland Greece in its bid for liberation. ${ }^{19}$ As he writes:

The magnified success of the Greeks in the cause of liberty, as it is called, inspired the Ionians with the most ridiculous fancies; the very thought of independance [sic] made them beside themselves - little aware that if the continent did free itself from the Turks, and they released from the British, that they would still be only a dependant [sic] state, and left precisely as they are now, without the ruling and protecting hand which the English government has always extended towards them. (223)

\footnotetext{
${ }^{19}$ The Ionian Islands were declared a British protectorate during the Convention of Vienna in 1815, with Thomas Maitland named their first Lord High Commissioner. Although the Constitution of 1817 assigned Britain as a "protectorate" of the Ionian Islands, Maitland treated the islands as a British colony. For more on British rule of the Ionian Islands see Michael Pratt, Britain's Greek Empire: Reflections on the History of the Ionian Island from the Fall of Byzantium, London: Rex Collings, 1978; and Maria Paschalidi, Constructing Ionian Identities: The Ionian Islands in British Official Discourses; 1815-1864, PhD Diss, University College London, 2010.
} 
For Kendrick, the Ionian Islands—and Greeks more generally—benefit from British rule, a position that earned him scorn from The Literary Chronicle, which deemed him an "enemy" of the Greek cause (53) and "a great advocate for the "powers that be" (52) in its review of his publication. Reading The Ionian Islands alongside The Travellers, I suggest, helps us to understand more fully Kendrick's political imperatives in his later written novel, and the future alliance he imagined between Britain and Greece. If Greeks were to be free, their best hope, according to Kendrick, was for the British to intervene in, and control, their national affairs.

By experimenting with notions of history and time, projecting their narratives both to the past and the future, Kendrick and Shelley create literary spaces from which to speculate about the Greek War of Independence and Britain's role in Greece's national future. More than this, though, the authors of both novels anticipate the global consequences of Greek independence and how British intervention in Greco-Ottoman warfare would ultimately impact not only Greece's national future, but Britain's and Europe's too. If Greece was implicated in the problematic of European modernity symbolized by Western intervention in its national uprising, so too was Britain, which ultimately had to make a decision — to support Greece or the Ottoman Empirethat would alter the course of European history. Like so many works about Greece written during the Romantic period, Shelley's and Kendrick's novels reveal the complicated and fascinating ways in which various personal, political, colonial, social, ideological, economic, and historical imperatives intersected and ultimately determined British support for Greek independence. 


\section{Conclusion}

Since 2009, Greece has featured frequently in newspaper headlines all over the world, but for mostly all the wrong reasons. As the country impacted the hardest by the European debt crisis, Greece has seen its once stable, albeit modest, economy contract to Great Depression-like levels, with unemployment currently sitting at $23.0 \%$ (and $44.2 \%$ for young adults). ${ }^{1}$ In order to pay its debts, Greece has since 2010 needed to secure a series of loans from the Troika (Russian for "set of three"), consisting of the European Commission (EC), the European Central Bank (ECB), and the International Monetary Fund (IMF). In return for Troika funds, Greece has been forced to implement various austerity measures which have helped the country to reduce its primary deficit but contributed to its recession, thus exacerbating Greece's financial problems. ${ }^{2}$ The unsustainability of Greece's mounting debts has led many experts to predict the country's departure from the Eurozone (coined "Grexit"), with Greeks reintroducing the Drachma as their currency and, troublingly for many, being restricted from travelling freely to and between other EU Member States. ${ }^{3}$ Negotiations between Greece and its creditors have been nothing short of dramatic, with tensions reaching a climax during the summer of 2015. The left-wing SYRIZA party ("Coalition of the Radical Left"), which won the January 2015 Greek elections on the promise of renegotiating Greece's debts, for months rejected the demands of the Troika's bailout agreement with previous governments and missed its 1.75 billion dollar payment to the IMF on 1

\footnotetext{
${ }^{1}$ The Business Insider (May 29, 2015) suggests that Greece's crisis is actually worse than that experienced by the U.S.A. from 1929-39 (a period often referred to as the Great Depression). See

http://www.businessinsider.com/greeces-depression-worse-great-depression-2015-5); EU unemployment statistics are recorded by Eurostat. See http://ec.europa.eu/eurostat/statistics-explained/index.php/Unemployment_statistics.

${ }^{2}$ In fact, the IMF has argued repeatedly that Greece requires substantial debt relief in order for its economy to recuperate, a suggestion that most EU member states are hesitant to implement.

${ }^{3}$ As the European Commission explains on its website: "Free movement of workers is a fundamental principle of the Treaty enshrined in Article 45 of the Treaty on the Functioning of the European Union and developed by EU secondary legislation and the Case law of the Court of Justice. EU citizens are entitled to: look for a job in another EU country; work there without needing a work permit; reside there for that purpose; stay there even after employment has finished; enjoy equal treatment with nationals in access to employment, working conditions and all other social and tax advantages." See http://ec.europa.eu/social/main.jsp?catId=457.
} 
July $2015 .{ }^{4}$ Greece barely avoided a Eurozone exit when SYRIZA, reneging on its electoral promises and ignoring the results of a 5 July 2015 referendum in which $61 \%$ of Greeks voted "no" to the Troika's bailout conditions, capitulated to the Troika and signed a debt repayment agreement on 12 July 2015. Despite the bailout, the financial situation remains volatile and Greece's future economic prospects remain unpromising to this day.

One of the main consequences of the European debt crisis has been the reemergence of a question that has surfaced periodically throughout Greece's almost 200 year history as a modern nation state: can Greece and the Greeks be characterized as European? In July 2015, reporter David A. Graham published an article in The Atlantic ("How Greece Became European") that opens with a provocative question- "Greece is the cradle of European civilization, but is it even in Europe?"- before offering a series of facts about Greece's geography, history, and national identity which complicate our understanding of the country's European heritage. Graham writes that "[i]f you look at old maps of Europe, the Balkan Peninsula is included, but it's labeled as Turkey" and remarks that the Greeks' "cultural center would have been not now-dusty Athens but cosmopolitan Constantinople.” Throughout his piece, Graham emphasizes Greece's complicated relationship with Europe's Great Powers and Greeks' ambivalence about their European identity. Graham's article is certainly not the only one of its kind, either. Earlier in 2015, in a piece more pointedly entitled "The Greeks are not 'Western," David Patrikarakos reminds readers that "Greece had been part of the Ottoman Empire from the mid- $15^{\text {th }}$ century until independence in 1830, so it never went through defining Western historical processes like the Renaissance and the Enlightenment." And even earlier still, Palash Ghosh in his 2011 article “Are Greeks Really European?" published in the International Business Times notes that

\footnotetext{
${ }^{4}$ For more on SYRIZA's negotiations with other EU members, see Helena Sheehan, Syriza Wave: Surging and Crashing with the Greek Left, New York: Monthly Review Press, 2016; and Casse Mudde, SYRIZA: The Failure of the Populist Promise, London: Palgrave, 2017.
} 
"[a]lthough Greece is considered the 'cradle of Western civilization,' the nation has had a vastly different history and trajectory from the dominant countries of Western Europe.” The Greek debt crisis does not mark the first historical instance of Greeks and non-Greeks scrutinizing Greece's European identity but what a potential Grexit has exposed for twenty-first century citizens is the deeper fault lines in the creation of a unified Europe and Greece's role therein. ${ }^{5}$ Greece's crisis, while predominantly economic, is therefore also a deeply political, cultural, and historical crisis for Greeks and the Western world.

Greece's current fallout with the Eurozone brings to the forefront many of the same issues British Romantic authors debated approximately 200 years earlier. British Romantic writers examined Greece's sociopolitical conditions, deliberated upon the country's Western history, charted the ways in which the Hellenic past was used to develop Modern Greek and European identities, and critiqued Europe's Great Powers for controlling the Greeks—all topics that scholars, authors, journalists, and political thinkers continue to explore to this day. Indeed, as I have discussed throughout my dissertation, the early nineteenth century was the period during which debates about Greece's place in the East and West emerged and it was British Romantic writers who helped British and European readers understand the profound political and cultural stakes involved in dislodging Greece from the Ottoman Empire and integrating it into Europe. British Romantic writers give us unique insight into the personal and political alliances, as well as the ideological underpinnings, involved in creating a unified Europe and Greece's central role in this process.

\footnotetext{
${ }^{5}$ Greek and foreign writers and scholars have for years debated the country's European identity. Most notably, Michael Herzfeld has published various books and articles examining Greek identity. He writes in Anthropology through the Looking-Glass: Critical Ethnography in the Margins of Europe (Cambridge: Cambridge University Press, 1987) that "[s]ome Greeks, some of the time, claim a European identity that other Greeks claim they have never attained or never desired. Greeks thus live out the tension between similarity and difference, or inclusion and exclusion, in an inhabited replay of anthropology's dilemma" (18). See too Michael Herzfeld, "Hellenism and Occidentalism: the Permutations of Performance in Greek Bourgeois Identity," Occidentalism: Images of the West, Ed. James G. Carrier, Oxford: Clarendon: 1995, pp. 218-33.
} 
From Owenson and Byron who defended Greeks' autonomy against foreigners, to Percy Bysshe Shelley who critiqued Europe's "uses" of the Hellenic past, to Mary Shelley who emphasized how Eastern warfare impacts Britain, all the writers I discuss recognized the magnitude of their own historical period wherein Greek, British, and European national politics converged. British Romantic writers realized that Britain and Greece in the early nineteenth century were becoming more politically and culturally allied than they had ever been before and that this fact would alter the course of European politics and history. In fact, following the destruction of the Ottoman Empire's fleet at Pylos (Navarino) in October 1827 by combined British, French, and Russian forces, the path was set for Greece's liberation and the establishment of a Europeanized Modern Greek nation state, as many writers and thinkers of the Romantic period had imagined and anticipated. Notably, though, Greeks themselves had little say in the political and geographical makeup of this newly created nation; instead, Britain, with France and Russia, negotiated the terms upon which the contemporary Greek nation would be established. From 1828 to 1832 , the three powers debated amongst themselves the geographical parameters of Greece and decided who would become the leader of the Greek nation. In May 1832, Britain, France, and Russia finally agreed to designate the 17 year old Bavarian prince, Otto of Wittelsbach, as the new leader of a monarchical and independent Greek state, a controversial choice amongst Greeks who deemed the Constitution of 1832 that made Otto king, and their country a monarchy, the "hegemonic constitution.",

\footnotetext{
${ }^{6}$ For more on the formation of the Modern Greek nation state post revolution, see John S. Koliopoulos and Thanos M. Veremis, Modern Greece: A History Since 1821, West Sussex: Blackwell, 2010; Roderick Beaton and David Ricks (eds.), The Making of Modern Greece: Nationalism, Romanticism, and the Uses of the Past (1797-1896), London: Routledge, 2009; Michael Herzfeld, Ours Once More: Folklore, Ideology, and the Making of Modern Greece, Austin: University of Texas Press, 1982; and Douglas Dakin, "The Formation of the Greek State, 1821-33," The Struggle for Greek Independence, Ed. Richard Clogg, London: Macmillan, 1973, pp. 156-81.
} 
Britain's role in establishing the Modern Greek nation in 1832 represents just the beginning of its increasing control over Greece and Greeks. This history includes Britain's rule over the Ionian Islands (until 1864), provocation of civil war in Greece following World War II, and poorly-executed departure from Cyprus after 88 years of quasi-colonial governance, which resulted in the island's North (Turkish)/South (Greek) partitioning in 1974 (intact to this day). ${ }^{7}$

Britain and Greece's 200 year relationship as European allies has never been straightforward and both parties have had their share of grievances. As Robert Holland and Diana Markides write, A hopefulness of British patronage firmly embedded in modern Hellenic political culture, and British expectations that the Greeks should subordinate and moderate their own aspirations whenever required, were often subject to a mutual disillusion all the greater because of the original expectations involved. Here again the benchmark of the founding revolution traced an inherent tendency to overlapping disappointments which was to repeat itself many times over. (9) Greece's "founding revolution" is where the complicated relationship between Greece and Britain (and Europe) began and reflecting upon the literary, cultural, and geopolitical formations of the Romantic period allows us to understand more clearly the significant historical processes in Europe that follow, up until our present moment. Certainly, Greece's relationship with Britain does not reflect entirely the Mediterranean country's association with the rest of Europe. However, because Britain from the Romantic period onwards was instrumental in shaping and

\footnotetext{
${ }^{7}$ The British ruled the Ionian Islands from 1815-1864 and Cyprus from 1878-1960. While Greece and Britain were allies during World War II, Prime Minister Churchill's political and monetary support for Royalist Greeks against Greek Communist forces is regarded as one of the causes of the Greek Civil War (1946-49) that followed the Second World War. Robert Holland and Diana Markides discuss Britain's occupations of the Ionian Islands and Cyprus in The British and the Hellenes: Struggles for Mastery in the Eastern Mediterranean, 1850-1960, Oxford: Oxford University Press, 2006. For an account of British-Greek relations during World War II, see Procopis Papastratis, British Policy Towards Greece During the Second World War 1941-1944, Cambridge: Cambridge University Press, 1984; and David Brewer, Greece, the Decade of War: Occupation, Resistance and Civil War, London: I.B. Tauris, 2016.
} 
controlling the politics of the Modern Greek nation state (up until the end of World War II), the relationship between the two countries epitomizes the unbalanced power dynamics between larger and smaller European nations which perhaps give us a glimpse into how Europe has progressed toward the "crises" (political and financial, but also cultural) that we are witnessing today.

Early nineteenth century British authors foreshadow how intertwined, complicated, and at times contentious Greece and Britain's relationship would become post revolution and beyond. Publications like Catherine Grace Godwin's Reine Canziani, which depicts a young Greek woman manipulated and abused by a British traveller, and Tertius Kendrick's The Travellers, which imagines Englishman Sidney Melcombe helping to revive Greece’s imperial past, demonstrate the broad spectrum of British Romantic writers' opinions about Greek-British relations and the "uses" of Greece. In examining power imbalances between Britain (and Europe) and Greece detailed in Romantic literature, I have portrayed Greeks as caught in the same types of dynamics as many postcolonial peoples, especially when I discuss how Greek characters in British Romantic works attempt to preserve their cultural identities in the face of British and European sociocultural, geopolitical, and ideological impositions. ${ }^{8}$ Of course, I remain conscious of the potential controversy of defining Greece in this way but, nevertheless, argue that the country can be deemed postcolonial as it was "the first nation to declare itself independent from the Ottoman Empire" (Jusdanis 171), which led it to become one of the earliest nation-states in Europe, only to be controlled largely by Britain. ${ }^{9}$ The British Romantic works I

\footnotetext{
${ }^{8}$ Two postcolonial theorists whose work informs my view of Greece as postcolonial are Dipesh Chakrabarty and Partha Chatterjee. See Dipesh Chakrabarty, Provincializing Europe: Postcolonial Thought and Historical Difference, Princeton: Princeton University Press, 2000; and Partha Chatterjee, The Nation and its Fragments: Colonial and Postcolonial Histories. Princeton: Princeton University Press, 1993.

${ }^{9}$ As Gregory Jusdanis writes in The Necessary Nation (Princeton: Princeton University Press, 2001), "Greece offers a fascinating twist to the postcolonial situation. Although viewed today as a European nation, it was ruled until 1821 by the Ottoman Empire, an Oriental society" (8).
} 
selected focus not only upon the positive aspects of Britain and Greece's affiliation, but also on how Britain treated Greece as another one of its colonies (especially pertinent as the Ionian Islands and Cyprus functioned as quasi-colonies), and thus on the effects of this colonization on British literary works about Greece.

Throughout my dissertation, I have emphasized that the political, literary, and cultural debates of the Romantic era helped to dislodge Modern Greece from the Ottoman Empire (and thus from the East) and to establish Greece as a contemporary Western nation state that was central to re-conceptualizing Europe as a more unified political and cultural formation. As Western borders begin to close today — and, importantly, the borders of Britain, a country that maintained throughout the nineteenth and twentieth centuries a leading role in constructing a "global" Europe — my study examines how and why they were formed and opened in the first place. Although my study primarily focuses on two countries, and cannot therefore reflect entirely the ways in which the crisis has been experienced throughout Europe, revisiting the Romantic period's modernizing of Greece, I suggest, can help us to rethink the initial literary, cultural, and political investments that contributed to today's European identity. While the Romantic nationalist thought of writers like Johann Gottfried Herder and Georg Wilhelm Friedrich Hegel inspired European support for the Greek revolution, the British Romantic works I examine also reveal the limitations of Romantic Nationalism in creating a pan-European ethos. The Greek-British transcultural relations that I detail throughout my dissertation give us insight into the fundamental problems inherent in constructing a unified Europe made up of separate sovereign national states and remind us that the current European crisis is also necessarily yet another breakdown of Hellenism, the ideology upon which European national identities were 
forged. ${ }^{10}$ And if, as Artemis Leontis argues, "scholars hold Hellenism accountable for the West's currently most despised vices: sexism, racism, colonialism, imperialism, metaphysics, the verb 'to be'" (224), this breakdown might not be entirely negative or unwarranted. If Greece in the nineteenth century was foundational for the construction of a Western identity buoyed by racism, imperialism, and a number of other harmful acts and beliefs, perhaps the Greece of today can help us to understand more clearly some European nations' current ambivalence about their shared political and cultural histories and to forge new, less divisive identities, especially important in light of the present rise of populist rightwing politics in the West. ${ }^{11}$

But what about the present predicament in Greece? How does British Romantic literature inform the material realities of Greece's current historical situation, especially in our present moment when a deeply conservative turn in Western politics threatens any sort of long term or effective resolution to Greece's financial crisis? Perhaps, in light of the historical parallels I have been drawing between nineteenth-century and twenty-first century Greece throughout this Conclusion, literature has something to tell us about resolving political and cultural impasses. The Greek War of Independence, a crisis in its own right, was itself waged against seemingly

\footnotetext{
${ }^{10}$ As Stathis Gourgouris argues, "the Nation exemplifies its link with the Enlightenment's imagination as an actualized form of an Enlightenment ethos, a secular-philosophical attitude toward life. In other words, the Nation is a philosophical predicament and, therefore, inevitably a Hellenic predicament, whether this is attested explicitly or not. Certainly, the distinct phenomenon by which national identity "does not present itself as a philosophy, but as philosophy itself" (Derrida 1992: 13) is a design immanent to the problematic of Hellenism as a problematic of modernity. For this reason, it deserves elucidation not merely through the reassessment of ancient Greek thought in the context of European cultural formation but by a meditation on that peculiar set of historical events that led to the formation of a distinct Neohellenic culture" (274). For Gourgouris, the problems we today recognize with the Nation as a political and cultural construct - problems which problematize the ideological underpinnings of the European Union, we should note - are inextricably linked to ideas about Hellenism developed during the late eighteenth and early nineteenth centuries. Importantly, Gourgouris emphasizes that the Hellenic ideology that went into constructing national identities is not only that of "ancient Greek thought" but also involves the political and cultural debates between Europe's Great Powers that forged a Modern Greece. See Stathis Gourgouris, Dream Nation: Enlightenment, Colonization, and the Institution of Modern Greece, Stanford: Stanford University Press, 1996.

${ }^{11}$ A survey conducted by the European Commission in 2015 found that only $56 \%$ of British and $50 \%$ of Greek individuals identify as "a citizen of the EU." By contrast, $88 \%$ of Lithuanians, $84 \%$ of the Maltese, and $81 \%$ of Germans surveyed said they felt like EU citizens. See page 17 of The European Commission, European Citizenship Report, The European Commission, 2015, Web. 4 Apr. 2017. (http://ec.europa.eu/public_opinion/archives/eb/eb83/eb83_citizen_en.pdf)
} 
impossible odds during an intensely conservative period in which the Great Powers of Europe discouraged any and all national uprisings. British Romantic writers of various political and social backgrounds were integral in convincing initially apathetic Europeans to support the Greek cause, reimagining Greek-European relations, and envisioning a Greece liberated from Ottoman rule and allied with European nations like Britain. While liberal-minded writers would have been more inclined to be openly supportive of Greece's liberation (i.e. Byron and Percy Bysshe Shelley), my study reveals that there was not political or ideological uniformity when it came to literary discourses about Greece. British Romantic writers both conservative and liberal recognized the benefits and difficulties associated with Europeanizing Greece and anticipated future problems that would arise when Europe's dominant powers attempted to govern the Greeks' national politics. Many of these writers maintained too, during the process of Greece's Europeanization, that Greeks' unique cultural, social, and historical plurality should be respected and preserved.

British Romantic writers also realized that discourses about Greece and Greeks' place in Europe were ultimately more than just about the Balkan country; they were inextricably linked to broader historical, cultural, and geopolitical shifts occurring in Britain and Europe during the Romantic period. Revisiting the Romantic era's literature about Greece invigorates and contextualizes the vital debates of today — certainly the economic, but also cultural, political, religious, and humanitarian — by reminding us how central Greece has been since the early nineteenth century in both problematizing and resolving the issues confronting Europe. Then, as now, Greek crisis invites intensive speculation on the foundations of national sovereignty and liberal democracy, on transnational cooperation, and on individual and shared social, cultural, and political histories. By examining British Romantic writers' multiple and varied engagements 
with nineteenth-century Greece, I have sought, finally, to rethink the ways in which we envision Greece in both the nineteenth and twenty-first centuries. The British Romantic writers I examine in this dissertation went beyond simple binaries or derivative clichés (i.e. glorious past, degenerate present) in their portrayals of Greece and instead regarded the emerging nation as a topos — both symbolic and material—-through which to contemplate and reimagine the prevailing issues and challenges that confronted them during their lifetimes. 


\section{Works Cited}

Aeschylus. "The Persians.” Prometheus Bound and Other Plays. Ed. Philip Vellacott. London: Penguin, 1961. 122-52. Print.

"Anastasius, or the Memoirs of a Greek; Written at the Close of the 18th Century." The Quarterly Review 24.48 (1821): 511-29. Web. 5 Mar. 2014.

“Anastasius: Or, Memoirs of a Greek." The Atheneum; or, Spirit of the English Magazines 7.2 (1820): 77-81. Web. 5 Mar. 2014.

Anderson, Benedict. Imagined Communities: Reflections on the Origin and Spread of Nationalism. London: Verso, 2006. Print.

Angelomatis-Tsougarakis, Helen. The Eve of the Greek Revival: British Travellers' Perceptions of Early Nineteenth-Century Greece. London: Routledge, 1990. Print.

“Art V. Parallèle de la Puissance Anglaise et Russe Relativement á l'Europe.” Westminster Review 1.1 (1824): 80-101. Web. 20 Apr. 2014.

“Art V. Anastasius; or Memoirs of a Greek, written in the $18^{\text {th }}$ Century." Edinburgh Review 35.69 (1821): 92-102. Web. 5 Mar. 2014.

“Art. VII. Woman; or Ida of Athens. By Miss Owenson, Author of 'The Wild Irish Girl,' the 'Novice of St. Dominick,' \&c. 4 Vols. 12 mo.” Monthly Review 58 (February 1809): 196200. Web. 5 Mar. 2014. 
"Art. XIV.—Anastasius; or Memoirs of a Greek: Written at the Close of the Last Century." North-American Review and Miscellaneous Journal 11.29 (1820): 271-306. Web. 5 Mar. 2014.

Ataç, C. Akça. "Imperial Lessons from Athens and Sparta: Eighteenth-Century British Histories of Ancient Greece." History of Political Thought 27.4 (2006): 642-60. Print.

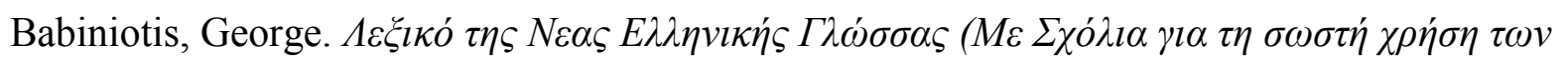
$\lambda \dot{\varepsilon} \xi \varepsilon(\omega v)$ [The Dictionary of Modern Greek]. Athens: Lexicology Centre, 2008. Print.

Bainbridge, Simon. Napoleon and English Romanticism. Cambridge: Cambridge UP, 1995. Print.

Bass, Gary J. Freedom's Battle: The Origins of Humanitarian Intervention. New York: Knopf, 2008. Print.

Bate, Walter Jackson. From Classic to Romantic: Premises of Taste in Eighteenth-Century England. New York: Harper \& Row, 1946. Print.

Battezzato, Luigi. "Lyric.” A Companion to Greek Tragedy. Ed. Justina Gregory. Oxford: Blackwell, 2005. 149-66. Print.

Beaton, Roderick. Byron's War: Romantic Rebellion, Greek Revolution. Cambridge: Cambridge UP, 2013. Print.

---. "Romanticism in Greece." Romanticism in National Context. Ed. Roy Porter and Mikuláš Teich. Cambridge: Cambridge UP, 1988. 92-108. Print. 
Beaton, Roderick and David Ricks. "Introduction." The Making of Modern Greece. Ed. Roderick Beaton and David Ricks. Surrey: Ashgate, 2009. 1-18. Print.

Bennett, Betty T. "Radical Imaginings: Mary Shelley's 'The Last Man." The Wordsworth Circle 26.3 (1995): 147-52. Print.

Bernal, Martin. Black Athena: The Afroasiatic Roots of Classical Civilization. New Jersey: Rutgers UP, 1987. Print.

---. Black Athena Writes Back: Martin Bernal Responds to His Critics. Ed. David Chioni Moore. Durham, NC: Duke UP, 2001. Print.

Bhabha, Homi K. The Location of Culture. London: Routledge, 1994. Print.

Bietoletti, Silvestra. Neoclassicism \& Romanticism 1770-1840. New York: Sterling, 2005. Print.

Bordoni, Silvia. "Lord Byron and Lady Morgan." The Byron Study Centre, Centre for Regional Literature and Culture University of Nottingham. 2006. Web. 10 Feb 2015.

Brewer, David. The Flame of Freedom: The Greek War of Independence 1821-1833. London: John Murray, 2001. Print.

---. Greece, the Decade of War: Occupation, Resistance and Civil War. London: I.B. Tauris, 2016. Print.

---. Greece, the Hidden Centuries. New York: I.B. Tauris, 2010. Print.

Bury, Lady Charlotte. The Diary of a Lady-In-Waiting. Ed. A. F. Steuart. Vol. 2. London: Lane, 1908. Print. 
Butler, Marilyn. Romantics, Rebels \& Reactionaries. Oxford: Oxford UP, 1981. Print.

Byron, George Gordon. Byron's Letters and Journals: Famous in my Time. Ed. Leslie Marchand. Vol. 2. Cambridge, MA: Harvard UP, 1977. Print.

---. Byron's Letters and Journals: Famous in my Time. Ed. Leslie Marchand. Vol. 7. Cambridge, MA: Harvard UP, 1978. Print.

---. Childe Harold's Pilgrimage, A Romaunt. 2nd ed. London: John Murray, 1812. Web. 10 May 2013.

---. Childe Harold's Pilgrimage, A Romaunt: And Other Poems. 7th ed. London: John Murray, 1814. Web. 11 May 2013.

---. “Childe Harold's Pilgrimage.” Lord Byron: The Major Works. Ed. Jerome J. McGann. Oxford: Oxford UP, 1986. 19-206. Print.

---. "Don Juan.” Lord Byron: The Major Works. Ed. Jerome J. McGann. Oxford: Oxford UP, 1986. 373-879. Print.

---. "English Bards and Scotch Reviewers." Lord Byron: The Complete Poetical Works. Ed. Jerome J. McGann. Vol. 1. Oxford: Oxford UP, 1980. 227-64. Print.

---. "The Giaour." Lord Byron: The Complete Poetical Works. Ed. Jerome J. McGann. Vol. 3. Oxford: Oxford UP, 1981. 39-82, 413-22. Print.

---. Note 1. “To John Hobhouse. 20 September 1811.” Byron's Letters and Journals. Ed. Leslie Marchand. Vol. 2. Cambridge, MA: Harvard UP, 1977. 102. Print. 
---. "Sardanapalus." Lord Byron: The Complete Poetical Works. Ed. Jerome J. McGann and Barry Weller. Vol. 6. Oxford: Oxford UP, 1980. 15-128. Print.

Cameron, Averil. Procopius and the Sixth Century. London: Routledge, 1985. Print.

Campbell, Mary. Lady Morgan: The Life and Times of Sydney Owenson. London: Pandora, 1988. Print.

Carney, James P. “Some Previously Unrecognized References to Classical Historians in Mary Wollstonecraft Shelley's The Last Man.” Notes and Queries 61.4 (2014): 527-30. Print.

Chakrabarty, Dipesh. Provincializing Europe: Postcolonial Thought and Historical Difference. Princeton: Princeton UP, 2000. Print.

Chapman, Tim. The Congress of Vienna: Origins, Processes and Results. London: Routledge, 1998. Print.

Chatterjee, Partha. The Nation and Its Fragments: Colonial and Postcolonial Histories. Princeton: Princeton UP, 1993. Print.

Cheeke, Stephen. “Wrong-Footed by Genre: Shelley’s Hellas.” Romanticism 2.2 (1996): 204-19. Print.

Clarke, M. L. Classical Education in Britain 1500-1900. Cambridge: Cambridge UP, 1959. Print.

Clogg, Richard. A Concise History of Greece. Cambridge: Cambridge UP, 2002. Print. 
Clyde, James. Romaic and Modern Greek Compared with One Another, and with Ancient Greek. Edinburgh: Sutherland and Knox, 1855. Print.

Cochran, Peter. "Songs and Stanzas, Stanzas and Songs: Greece in Childe Harold and Greece in Don Juan." Byron's Poetry. Ed. Peter Cochran. Newcastle upon Tyne, England: Cambridge Scholars, 2012. 171-77. Print.

Cohen, Ralph, ed. Studies in Eighteenth-Century British Art and Aesthetics. Berkeley: U of California P, 1985. Print.

Colley, Linda. Britons: Forging the Nation 1707-1837. New Haven: Yale UP, 1992. Print.

Comet, Noah. Romantic Hellenism and Women Writers. New York: Palgrave, 2013. Print.

Constantine, David. In the Footsteps of the Gods: Travellers to Greece and the Quest for the Hellenic Ideal. London: Tauris, 2011. Print.

Crompton, Louis. Byron and Greek Love: Homophobia in $19^{\text {th }}$-Century England. Berkeley: U of California P, 1985. Print.

Crow, Thomas. "Classicism in Crisis: Gros to Delacroix." Nineteenth Century Art: A Critical History. Ed. Stephen F. Eisenman et al. London: Thames and Hudson, 1994. Print.

D’Israeli, Isaac. "Of a Biography Painted.” Curiosities of Literature. New York: William Pearson, 1835. Print.

Dakin, Douglas. “The Formation of the Greek State, 1821-33.” The Struggle for Greek Independence. Ed. Richard Clogg, London: Macmillan, 1973. 156-81. Print. 
---. The Greek Struggle for Independence 1821-1833. Berkeley: U of California P, 1973. Print.

Davison, Roderic H. Essays in Ottoman and Turkish History, 1774-1923: The Impact of the West. Austin: U of Texas P, 1990. Print.

De Lauretis, Teresa. Technologies of Gender: Essays on Theory, Film, and Fiction. Bloomington: Indiana UP, 1987. Print.

Demetriou, Kyriacos. "In Defence of the British Constitution: Theoretical Implications of the Debate over Athenian Democracy in Britain, 1770-1850.” History of Political Thought 17.2 (1996): 280-97. Print.

Demetriou, Spiridoula. "The Creation of Modern Greece: Travel, Art and Philhellenism in the Collection of the State Library of Victoria." La Trobe Journal 82 (2008): 66-87. Web. 10 Oct. 2014.

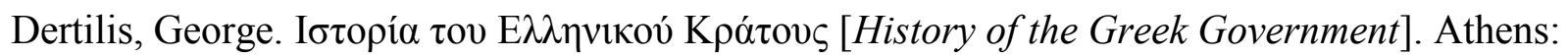
Estia, 2009. Print.

Diamandouros, P. Nikiforos, Thalia Dragonas, and Çağlar Keyder, eds. Spatial Conceptions of the Nation: Modernizing Geographies in Greece and Turkey. London: Tauris, 2010. Print.

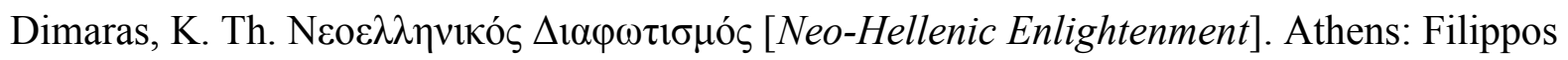
Iliou, 1989. Print. 
"The Domestic Policy of the British Empire, Viewed in Connexion with its Foreign Interests." The Edinburgh Review 78 (January 1824): 281-99. Web. 10 August 2015.

Donovan, Julie. Sydney Owenson and the Politics of Style: 1800-1835. PhD Diss. George Washington U, 2007. Web. 20 Jun. 2014.

Dué, Casey. The Captive Woman's Lament in Greek Tragedy. Texas: U of Texas P, 2006. Print.

Ebbott, Mary. "Marginal Figures." A Companion to Greek Tragedy. Ed. Justina Gregory. Oxford: Blackwell, 2005. 366-76. Print.

Erkelenz, Michael. “Inspecting the Tragedy of Empire: Shelley's Hellas and Aeschylus' Persians." Philological Quarterly 76.3 (1997): 313-37. Print.

The European Commission. European Citizenship Report. The European Commission, 2015. Web. 4 Apr. 2017.

Evans, Eric J. The Great Reform Act of 1832. London: Routledge, 1983. Print.

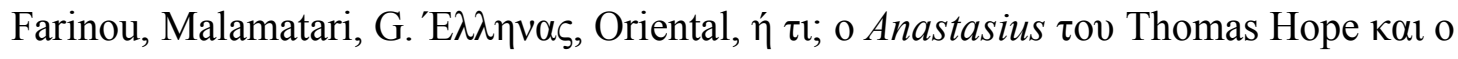

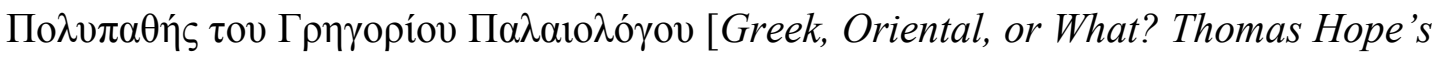

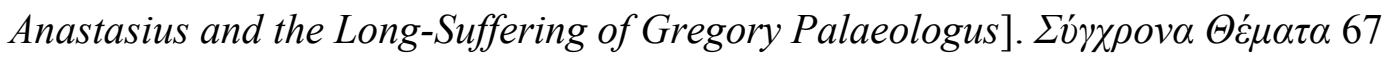
(1998): 27-35. Print.

Felluga, Dino. “'With a Most Voiceless Thought': Byron and the Radicalism of Textual Culture." European Romantic Review 11.2 (2000): 150-67. Print.

Ferris, David S. Silent Urns: Romanticism, Hellenism, Modernity. Stanford: Stanford UP, 2000. Print. 
Ferris, Ina. "Writing on the Border: The National Tale, Female Writing, and the Public Sphere." Romanticism, History, and the Possibilities of Genre. Ed. Tilottama Rajan and Julia M. Wright. Cambridge: Cambridge UP, 1998. Print.

Findlay, L. M. “'We Are All Greeks': Shelley's Hellas and Romantic Nationalism.” History of European Ideas 16.1-3 (1993): 281-86. Print.

Fisch, Audrey A. "Plaguing Politics: AIDS, Deconstruction, and The Last Man." The Other Mary Shelley: Beyond Frankenstein. Ed. Audrey A. Fisch, Anne K. Mellor, and Esther H. Schor. New York: Oxford UP, 1993. 267-86. Print.

Foucault, Michel. The Archaeology of Knowledge and the Discourse on Language. Trans. A.M. Sheridan Smith. New York: Pantheon Books, 1972. Print.

“Free Movement - EU nationals.” European Commission. n.d. Web. 5 January 2017.

Fulford, Tom. Romanticism and Masculinity: Gender, Politics and Poetics in the Writings of Burke, Coleridge, Cobbett, Wordsworth, De Quincey, and Hazlitt. London: Macmillan, 1999. Print.

Galt, John. Letters from the Levant. London: T. Cadell and W. Davies, 1813. Web. 5 May 2013.

Garland, Robert. The Greek Way of Life: From Conception to Old Age. Ithaca, NY: Cornell UP, 1990. Print.

“Geographie de Strabon.” Edinburgh Review 16.31 (1810): 55-61. Web. 10 Dec. 2012.

Ghosh, Palash. “Are Greeks Really European?” International Business Times 11 Sept. 2011. Web. 22 Dec. 2016. 
Gilmartin, Kevin. Writing Against Revolution: Literary Conservatism in Britain, 1790-1832. Cambridge: Cambridge UP, 2007. Print.

Godwin, Catherine Grace. Reine Canziani: A Tale of Modern Greece. London: Hurst, Robinson, 1825. Web. 15 May 2013.

Godwin, William. Essay on Sepulchres. London: W. Miller, 1809. Web. 25 Nov. 2016.

Gottlieb, Evan. Romantic Globalism: British Literature and Modern World Order 1750-1830. Columbus: Ohio State UP, 2014. Print.

Gounaris, Basil C. "Modern Nation and Caricature State: Competing Greek Perspectives on the Balkans and Hellas (1797-1896)." The Making of Modern Greece. Ed. Roderick Beaton and David Ricks. Surrey: Ashgate, 2009. 137-47. Print.

Gourgouris, Stathis. Dream Nation: Enlightenment, Colonization, and the Institution of Modern Greece. Stanford: Stanford UP, 1996. Print.

Graham, David A. "How Greece Became European.” The Atlantic 7 July 2015. Web. 22 Dec. 2016.

Graves, Robert. Greek Myths. 2 vols. New York: George Braziller, 1957. Print.

---. The Greek Myths: Complete Edition. London: Penguin, 1992. Print.

Greene, Roland. Unrequited Conquests: Love and Empire in the Colonial Americas. Chicago: U of Chicago P, 2000. Print. 
Greenhalgh, P. A. L and Edward Eliopoulos. Deep Into Mani: Journey to the Southern Tip of Greece. Boston: Faber and Faber, 1985. Print.

Grewal, Inderpal. Home and Harem: Nation, Gender, Empire and the Cultures of Travel. Durham, NC: Duke UP, 1996. Print.

Griffith, Mark. "Authority Figures.” A Companion to Greek Tragedy. Ed. Justina Gregory. Oxford: Blackwell, 2005. 333-51. Print.

Grigsby, Darcy Grimaldo. Extremities: Painting Empire in Post-Revolutionary France. New Haven: Yale UP, 2002. Print.

Gunne, Sorcha and Zoë Brigley Thompson, eds. Feminism, Literature and Rape Narratives: Violence and Violation. London: Routledge, 2010. Print.

Hamilakis, Yannis. The Nation and Its Ruins: Antiquity, Archaeology, and National Imagination in Greece. Oxford: Oxford UP, 2007. Print.

Hamilton, Elizabeth. Memoirs of Modern Philosophers. Ed. Claire Grogan. Peterborough, ON: Broadview, 2000. Print.

Hemans, Felicia. "The Bride of the Greek Isle." Selected Poems, Letters, Reception Materials. Ed. Susan J. Wolfson. Princeton: Princeton UP, 2000. 340-46. Print.

---. "Modern Greece, A Poem.” Felicia Hemans: Selected Poems, Letters, Reception Materials. Ed. Susan J. Wolfson. Princeton: Princeton UP, 2000. 34-69. Print.

---. “The Parting Song.” Poems by Mrs. Hemans. London: George Routledge and Sons, 1885. 373-75. Print. 
---. "The Sisters of Scio." Poems by Mrs. Hemans. London: George Routledge and Sons, 1885. 451-52. Print.

---. "The Voice of Scio." Poems by Mrs. Hemans. London: George Routledge and Sons, 1885. 44-45. Print.

Henderson, G.P. The Revival of Greek Thought 1620-1830. Albany: State U of New York P, 1970. Print.

Herzfeld, Michael. Anthropology Through the Looking-Glass: Critical Ethnography in the Margins of Europe. Cambridge: Cambridge UP, 1987. Print.

---. "Hellenism and Occidentalism: The Permutations of Performance in Greek Bourgeois Identity." Occidentalism: Images of the West. Ed. James G. Carrier. Oxford: Clarendon, 1995. 218-33. Print.

---. Ours Once More: Folklore, Ideology, and the Making of Modern Greece. Austin: U of Texas P, 1982. Print.

Hoeveler, Diane Long and Jeffrey Cass, eds. Interrogating Orientalism: Contextual Approaches and Pedagogical Practices. Columbus: Ohio State UP, 2006. Print.

Holland, R. F. and Diana Weston Markides. Britain and the Hellenes: Struggles for Mastery in the Eastern Mediterranean 1850-1960. New York: Oxford UP, 2006. Print.

Holodny, Elena. "Greece's Economic Nightmare is Worse than the US' Great Depression." Business Insider 29 May 2015. Web. 22 Dec. 2016. 
Hope, Thomas. Anastasius, or, Memoirs of a Greek; Written at the Close of the Eighteenth Century. 4th ed. 3 vols. London: John Murray, 1827. Print.

---. Household Furniture and Interior Decoration. London: Longman, Hurst, Rees, and Orme, 1807. Web. 10 Dec. 2015.

Horrock, Geoffrey. Greek: A History of the Language and Its People. West Sussex: Longman Publishing Group, 2010. Print.

Housepian, Marjorie. Smyrna 1922: The Destruction of a City. London: Faber and Faber, 1972. Print.

“The Ionian Islands. By Tertius T.C. Kendrick, Esq.” Literary Chronicle 141 (January 1822): 5253. Web. 15 Oct. 2015.

Joseph, John. Language and Identity: National, Ethnic, Religious. New York: Palgrave, 2004. Print.

Jusdanis, Gregory. “Introduction: Modern Greek! Why?” Journal of Modern Greek Studies 15.2 (1997): 167-74. Print.

---. The Necessary Nation. Princeton: Princeton UP, 2001. Print.

Kaldellis, Anthony. Hellenism in Byzantium: The Transformations of Greek Identity and the Reception of the Classical Tradition. Cambridge: Cambridge UP, 2007. Print.

---. Procopius of Caesarea: Tyranny, History, and Philosophy at the End of Antiquity. Philadelphia: U of Pennsylvania P, 2004. Print. 
Kalymniou, Dean. “The Byzantines of Cornwall.” Neos Kosmos (April 2015). Web. 5 Aug. 2016.

Kasaba, Reşat. “The Enlightenment, Greek Civilization and the Ottoman Empire: Reflections on Thomas Hope's Anastasius.” Journal of Historical Sociology 16.1 (2013): 1-21. Print.

---. The Ottoman Empire and the World Economy: The Nineteenth Century. Albany: State U of New York P, 1988. Print.

Kazhdan, Alexander P. "Ecclesiastical Historians." The Oxford Dictionary of Byzantium. Oxford: Oxford UP, 1991. 670-71. Print.

Kendrick, Tertius T.C. The Ionian Islands. London: James Haldane, 1822. Web. 15 May 2013.

---. The Travellers. 2 vols. London: C.S. Arnold, 1825. Web. 15 May 2013.

Kim, Benjamin. Wordsworth, Hemans, and Politics, 1800-1830: Romantic Crises. Lanham, Maryland: Bucknell UP, 2013. Print.

Kipperman, Mark. "History and Ideality: The Politics of Shelley’s Hellas." Studies in Romanticism 30.2 (1991): 147-68. Print.

Kitromilides, Paschalis M. Enlightenment and Revolution: The Making of Modern Greece. Cambridge, MA: Harvard UP, 2013. Print.

---. "The Enlightenment in Southeast Europe: Introductory Considerations." Discourses of Collective Identity in Central and Southeast Europe (1770-1945). Ed. Balázs Trencsényi and Michal Kopeček. Vol 1. Budapest: Central European UP, 2006. 45-56. Print. 
Knight, Roger. Britain Against Napoleon: The Organization of Victory 1793-1815. London: Penguin, 2014. Print.

Koliopoulos, John S. and Thanos M. Veremis. Modern Greece: A History since 1821. West Sussex: Blackwell, 2010. Print.

Kolocotroni, Vassiliki and Efterpi Mitsi. Women Writing Greece: Essays on Hellenism, Orientalism and Travel. Amsterdam: Rodopi, 2008. Print.

Kostova, Ludmilla. "Degeneration, Regeneration and the Moral Parameters of Greekness in Thomas Hope's Anastasius, or Memoirs of a Greek." Comparative Critical Studies 4.2 (2007): 177-92. Print.

Koundoura, Maria. "Beware of (Phil)Hellenes Bringing Gifts: Lord Byron and Greece." AngloAmerican Perceptions of Hellenism. Ed. Tatiani G. Rapatzikou. Newcastle: Cambridge Scholars, 2007. Print.

---. "The Limits of Civility: Culture, Nation, and Modernity in Mary Shelley's The Last Man." Colby Quarterly 37.2 (2001): 164-73. Print.

---. "Real Selves and Fictional Nobodies: Women's Travel Writing and the Production of Identities." Women Writing Greece: Essays on Hellenism, Orientalism and Travel. Ed. Vassiliki Kolocotroni and Efterpi Mitsi. Amsterdam: Rodopi, 2008. 77-96. Print.

“The Last Man. By the Author of Frankenstein." The Panoramic Miscellany, or Monthly Magazine and Review of Literature, Sciences, Arts, Inventions, and Occurences 1 (March 1826): 380-86. Web. 20 Oct. 2016. 
Leask, Nigel. "Byron and the Eastern Mediterranean: Childe Harold II and the 'Polemic of Ottoman Greece." The Cambridge Companion to Byron. Cambridge: Cambridge UP, 2004. 99-117. Print.

Lefkowitz, Mary R. and Guy Maclean Rogers, eds. Black Athena Revisited. Chapel Hill, NC: North Carolina UP, 1996. Print.

Leontis, Artemis. Topographies of Hellenism: Mapping the Homeland. New York: Cornell UP, 1995. Print.

“Letter from Thomas Hope, Esq.” Blackwood's Edinburgh Magazine (October 1821): 312. Web. 10 Jul. 2015.

Levin, Harry. The Broken Column: A Study in Romantic Hellenism, Bowdoin Undergraduate Prize Essay. Cambridge, MA: Harvard UP, 1931. Print.

Liakos, Antonis. "Hellenism and the Making of Modern Greece: Time, Language, Space." Hellenisms: Culture, Identity and Ethnicity from Antiquity to Modernity. Ed. Katerina Zacharia. Aldershot: Ashgate, 2008. 201-36. Print.

Locke, John. Two Treaties of Government. London: Awnsham and John Churchill, 1698. Web. 18 Jul. 2015.

Luu, Helen. 'Fantasies of 'Woman': Hemans's Deconstruction of 'Femininity' in Records of Woman." Women's Writing 21.1 (2014): 41-57. Print.

Macfie, Alexander Lyon. The Eastern Question 1774-1923: Revised Edition. New York: Routledge, 2014. Print. 
Mackridge, Peter. Language and National Identity in Greece, 1766-1976. Oxford: Oxford UP, 2009. Print.

Marchand, Leslie. Byron: A Portrait. New York: Knopf, 1970. Print.

Martin, Philip W. "Heroism and History: Childe Harold I and II and the Tales." The Cambridge Companion to Byron. Cambridge: Cambridge UP, 2004. 77-98. Print.

Matar, Nabil. "Christians in the Eighteenth-Century Ottoman Mashriq." Eighteenth-Century Studies 47.2 (2014): 177-94. Print.

Mazis, John Athanasios. The Greeks of Odessa: Diaspora Leadership in Late Imperial Russia. New York: Columbia UP, 2004. Print.

McClintock, Anne. Imperial Leather: Race, Gender, and Sexuality in the Colonial Contest. London: Routledge, 1995. Print.

McGann, Jerome. Fiery Dust: Byron's Poetic Development. Chicago: U of Chicago P, 1968. Print.

McWhir, Anne. "Introduction.” The Last Man. Ed. Anne McWhir. Peterborough, ON: Broadview, 1996. xii-xxxvi. Print.

Mellor, Anne K. Mary Shelley: Her Life, Her Fiction, Her Monsters. New York: Routledge, 1989. Print.

Miliori, Margarita. "Europe, the Classical Polis, and the Greek Nation: Philhellenism and Hellenism in Nineteenth-Century Britain.” The Making of Modern Greece. Ed. Roderick Beaton and David Ricks. Surrey: Ashgate, 2009. 65-80. Print. 
Minta, Stephen. "The Image of Greece in Childe Harold's Pilgrimage and Don Juan." Byron's Poetry. Ed. Peter Cochran. Newcastle upon Tyne, England: Cambridge Scholars, 2012. 178-94. Print.

---. "Lord Byron and Mavrokordatos.” Romanticism 12.2 (2006): 126-42. Print.

---. On a Voiceless Shore: Byron in Greece. New York: Henry Holt, 1998. Print.

Mitford, Mary. The Life of Mary Russell Mitford. Ed. A. G. L'Estrange. 3 vols. London: Bentley, 1870. Print.

More, Hannah. Strictures on the Modern System of Female Education: With a View of the Principles and Conduct Prevalent Among Women of Rank and Fortune. 2 vols. London: Cadell and Davies, 1799. Print.

Mourtisen, Henrik. "Modern Nations and Ancient Models: Italy and Greece Compared." The Making of Modern Greece. Ed. Roderick Beaton and David Ricks. Surrey: Ashgate, 2009. 43-49. Print.

Mouzelis, Nicos P. Modern Greece: Facets of Underdevelopment. London: Macmillan, 1978. Print.

Mudde, Casse. SYRIZA: The Failure of the Populist Promise. London: Palgrave, 2017. Print.

Muir, Rory. Britain and the Defeat of Napoleon, 1807-1815. New Haven: Yale UP, 1996. Print.

Murray, John. "Letter to Oliver \& Boyd." 8 January 1820. Oliver \& Boyd Papers, Correspondence 1815-21 File, National Library of Scotland. 
---. Divide Ledgers A, B and BB, Archives of the House of Murray.

Murray, Julie. "Histories of Female Progress in Memoirs of Modern Philosophers." EighteenthCentury Fiction 22.4 (2010): 673-92. Print.

Nicholls, Peter. "Herman Melville: Scepticism, Cynicism, and the Memoirs of a Greek." Textual Practice 29.1 (2015): 45-70. Print.

O’Dea, Gregory. "Prophetic History and Textuality in Mary Shelley's The Last Man." Papers on Language and Literature 28.3 (1992): 283-304. Print.

Oakley, John Howard and Rebecca H. Sinos. The Wedding in Ancient Athens. Madison, WI: The U of Wisconsin P, 1993. Print.

Osman, Sharifah Aishah. “'Mightier than Death, Untamable by Fate': Felicia Hemans's Byronic Heroines and the Sorority of the Domestic Affections." Romanticism on the Net 43 (2006). Web. 5 Jan. 2016.

Owenson, Sydney (Lady Morgan). Lady Morgan's Memoirs: Autobiography, Diaries and Correspondence. Ed. W. Hepworth Dixon. 2 vols. London: William H. Allen, 1862. Print.

---. Woman: Or Ida of Athens. 4 vols. London: Longman, Hurst, Rees, and Orme, 1809. Web. 15 May 2013.

Paley, Morton D. "The Last Man: Apocalypse without Millennium.” The Other Mary Shelley: Beyond Frankenstein. Ed. Audrey A. Fisch, Anne K. Mellor, and Esther H. Schor. New York: Oxford UP, 1993. Print. 
Papachristou, Panayotis Alexandrou. The Three Faces of the Phanariots: An Inquiry into the Role and Motivations of the Greek Nobility under Ottoman Rule, 1683-1821. PhD Diss. Simon Fraser U, 1992. Web. 5 Jan. 2015.

Papastratis, Procopis. British Policy towards Greece during the Second World War 1941-1944. Cambridge: Cambridge UP, 1984. Print.

Paschalidi, Maria. Constructing Ionian Identities: The Ionian Islands in British Official Discourses; 1815-1864. PhD Diss. U College London, 2010. Web. 30 Jun. 2016.

Patrikarakos, David. “The Greeks are not 'Western.” Politico 22 April 2015. Web. 22 Dec. 2016.

Pearson, Jacqueline. Women's Reading in Britain 1750-1835: A Dangerous Recreation. Cambridge: Cambridge UP, 1999. Print.

Pfister, Manfred. "Introduction." The Fatal Gift of Beauty: The Italies of British Travellers, An Annotated Anthology. Ed. Manfred Pfister. Amsterdam: Rodopi, 1996. 1-22. Print.

Philliou, Christine M. Biography of an Empire: Governing Ottomans in an Age of Revolution. Berkeley: U of California P, 2011. Print.

Phillips, Mark. On Historical Distance. New Haven: Yale UP, 2013. Print.

---. Society and Sentiment: Genres of Historical Writing in Britain, 1740-1820. Princeton, NJ: Princeton UP, 2000. Print.

Politis, Linos. A History of Modern Greek Literature. Oxford: Clarendon Press, 1973. Print. 
Polwhele, Richard. Grecian Prospects: A Poem, in Two Cantos. London: Cadell and Davies, 1799. Web. 25 May 2014.

Pratt, Mary Louise. Imperial Eyes: Travel Writing and Transculturation. London: Routledge, 2007. Print.

Pratt, Michael. Britain's Greek Empire: Reflections on the History of the Ionian Island from the Fall of Byzantium. London: Rex Collings, 1978. Print.

Procopius. History of the Wars, Volume 1. Trans. H. B. Dewing. Cambridge, MA: Harvard UP, 2016. Print.

Raizis, Marius Byron. “Lord Byron and Greek Orthodoxy.” Balkan Studies 27.1 (1986): 89-104. Print.

Ravelhofer, Barbara. "Oral Poetry and the Printing Press in Byron's The Giaour (1813)." Romanticism 11.1 (2005): 23-40. Print.

“Reine Canziani; A Tale of Modern Greece." The Gentleman's Magazine and Historical Chronicle August 1825: 156-57. Web. 20 Apr. 2015.

“Reine Canziani, a Tale of Modern Greece." Literary Gazette: A Weekly Journal of Literature, Science, and the Fine Arts May 1825: 344. Web. 20 Apr. 2015.

"Reine Canziani, a Tale of Modern Greece." Philomathic Journal and Literary Review IV (1826): 208-9. Web. 20 Apr. 2015.

"Review of The Last Man." Literary Gazette and Journal of Belles Lettres, Arts, Sciences, \&c. 473 (February 1826): 102-3. Web. 20 October 2016. 
Rodenbeck, John. "Foreword.” Anastasius. n.p.: Long Riders' Guild Press, 2008. Print.

Roessel, David. In Byron's Shadow: Modern Greece in the English \& American Imagination. Oxford: Oxford UP, 2002. Print.

Rose, Gillian. "Place and Identity: A Sense of Place." A Place in the World? Places, Cultures and Globalization. Ed. Doreen Massey and Pat Jess. Oxford: Open U, 1995.88-132. Print.

Rosen, F. Bentham, Byron, and Greece: Constitutionalism, Nationalism, and Early Liberal Political Thought. Oxford: Clarendon P, 1992. Print.

Rosser, John H. The A to Z of Byzantium. Lanham, MD: Scarecrow Press, 2006. Print.

Rousseau, Jean Jacques. On the Social Contract. New York: Dover, 2003. Print.

Sachs, Jonathan. Romantic Antiquity: Rome in the British Imagination, 1789-1832. Oxford: Oxford UP, 2010. Print.

Said, Edward W. Culture and Imperialism. New York: Random House, 1993. Print.

---. Orientalism: Western Conceptions of the Orient. London: Penguin, 1978. Print.

Schoina, Maria. Romantic 'Anglo-Italians': Configurations of Identity in Byron, the Shelleys, and thePisan Circle. Surrey: Ashgate, 2009. Print.

Seymour, Miranda. Mary Shelley. London: John Murray, 2000. Print.

Sharafuddin, Mohammed. Islam and Romantic Orientalism: Literary Encounters with the Orient. New York: Tauris, 1994. Print. 
Shaw, Albert. "The Greeks of To-day." The Chautauquan; A Weekly Newsmagazine 11.3 (1890): 303-7. Print.

Sheehan, Helena. Syriza Wave: Surging and Crashing with the Greek Left. New York: Monthly Review P, 2016. Print.

Shelley, Mary. The Last Man. Ed. Anne McWhir. Peterborough, ON: Broadview, 1996. Print.

---. The Letters of Mary Shelley. Ed. P.R. Feldman and D. Scott-Kilvert. 2 vols. Oxford: Oxford UP, 1987. Print.

Shelley, Percy Bysshe. "Hellas.” The Major Works, Including Poetry, Prose, and Drama. Ed. Zachary Leader and Michael O'Neill. Oxford: Oxford UP, 2003. 548-87. Print.

---. "On the Literature, the Arts, and the Manners of the Athenians." Shelley: Prose Works. Ed. Richard Herne Shepherd. Vol. 2. London: Chatto \& Windus, 1897. 39-47. Print.

Sifaki, Evgenia. "A Gendered Vision of Greekness: Lady Morgan's Woman: Or Ida of Athens." Women Writing Greece: Essays on Hellenism, Orientalism and Travel. Ed. Vassiliki Kolocotroni and Efterpi Mitsi. Amsterdam: Rodopi, 2008. Print.

Smiley, Will. “'After Being So Long Prisoners, They Will Not Return to Slavery in Russia': An Aegean Network of Violence between Empires and Identities." The Journal of Ottoman Studies XLIV (2014): 221-34. Print.

--- "War without War: The Battle of Navarino, the Ottoman Empire, and the Pacific Blockade." Journal of the History of International Law 18 (2016): 42-69. Print. 
Solomou, Kiriakoula. Byron and Greek Poetry. Athens: National and Capodistrian U of Athens, School of Philosophy, 1980. Print.

Sommerstein, Alan H. The Tangled Ways of Zeus: And Other Studies In and Around Greek Tragedy. Oxford: Oxford UP, 2010. Print.

Spencer, Terence. Fair Greece Sad Relic: Literary Philhellenism from Shakespeare to Byron. London: Weidenfeld and Nicolson, 1954. Print.

St. Clair, William. That Greece Might Still Be Free: The Philhellenes in the War of Independence. Oxford: Oxford UP, 1972. Print.

Stern, Bernard Herbert. The Rise of Romantic Hellenism in English Literature, 1732-1786. London: Octagon, 1969. Print.

Stock, Paul. The Shelley-Byron Circle and the Idea of Europe. Basingstoke: Palgrave, 2010. Print.

Trumpener, Katie. Bardic Nationalism: The Romantic Novel and the British Empire. Princeton: Princeton UP, 1997. Print.

Tsigakou, Fani-Maria. The Rediscovery of Greece: Travellers and Painters of the Romantic Era. London: Thames and Hudson, 1981. Print.

Turhan, Filiz. The Other Empire: British Romantic Writings about the Ottoman Empire. New York: Routledge, 2003. Print.

Tzanaki, Demetra. Women and Nationalism in the Making of Modern Greece: The Founding of the Kingdom to the Greco-Turkish War. London: Palgrave, 2009. Print. 
Ulmer, William A. "Hellas and the Historical Uncanny." English Literary History 8.3 (1991): 611-32. Print.

“Unemployment statistics.” Eurostat. 1 Dec. 2016. Web. 5 January 2017.

Van Steen, Gonda. Liberating Hellenism from the Ottoman Empire: Comte de Marcellus and the Last of the Classics. New York: Palgrave, 2010. Print.

Vergil. Aeneid. Trans. Theodore C. Williams. Boston: Houghton Mifflin, 1910. Print.

Wallace, Jennifer. Shelley and Greece: Rethinking Romantic Hellenism. New York: St. Martin's, 1997. Print.

Wang, Fuson. "We Must Live Elsewhere: The Social Construction of Natural Immunity in Mary Shelley's The Last Man.” European Romantic Review 22.2 (2011): 235-55. Print.

Watkins, Daniel P. Social Relations in Byron's Eastern Tales. Madison, NJ: Fairleigh Dickinson UP, 1987. Print.

Webb, Timothy. "Childe Harold's Pilgrimage: Annotating the Second Canto." The Byron Journal 41.2 (2013): 127-43. Print.

---. English Romantic Hellenism, 1700-1824. Manchester: Manchester UP, 1982. Print.

Wolfson, Susan. ““A Problem Few Dare Imitate': Sardanapalus and 'Effeminate Character.” English Literary History 54.4 (1991): 867-902. Print.

---. Borderlines: The Shifting of Gender in British Romanticism. Stanford: Stanford UP, 2006. Print. 
---. "Hemans and the Romance of Byron." Felicia Hemans: Reimagining Poetry in the Nineteenth Century. Ed. Nanora Sweet and Julie Melnyk. New York: Palgrave, 2001. 155-80. Print.

Woodhouse, C.M. The Greek War of Independence: Its Historical Setting. New York: Hutchinson's U Library, 1952. Print.

---. The Philhellenes. London: Hodder and Stoughton, 1969. Print.

Yuval-Davis, Nira and Floya Anthias, eds. Women-Nation-State. London: Macmillan, 1989. Print. 